تقويم بر امج الدر اسات العليا بأقسام الإعلام التربوي بكليات التربية النو عية

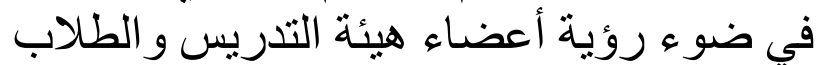

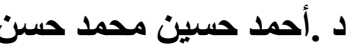

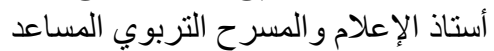
كلية التربية النوعية- جامعة المنصورة النئ. مصر.

الضعف وعلاجها، وهو أيضا ضرورة ملحة ومطلب هام من مطالب التمية المهنية والذاتية لأعضاء هيئة التدريس والباحثين في مجال التهال

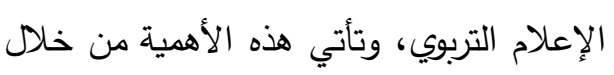
أنها هي المعنية بالدرجة الأولي بالإعداد الإدية والتأهيل الجيد لأعضاء هيئة التدريس الإعلام

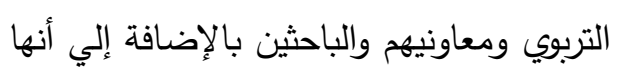
المسئولة عن توجيه الإنتاجية العلمية لأبحاثهر الإنها

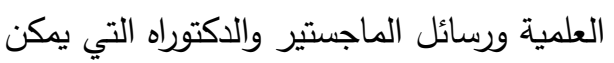
من خلالها المساهمة في حل مشكلات وقضايا

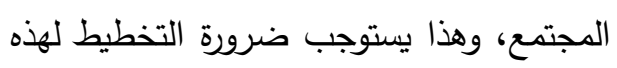
البرامج والإعداد الجيد للباحثين وإلا تعرضت

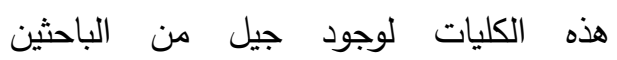
الحاصلين علي درجتي الماجستير والدكتوراه كولكنهم يفتقدون القدرة علي مهارات التفكير الإبداعي الناقد ومهارات البحث العلمي في حل

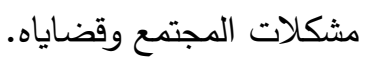
وانطلاقا من ذلك جاءت هذه الدانداء لتقويم برامج الدراسات العليا بأقسام الإعلام

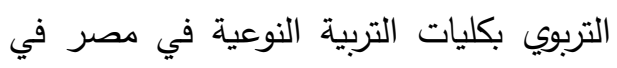

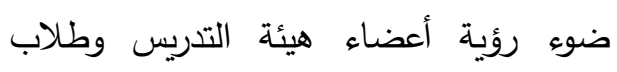

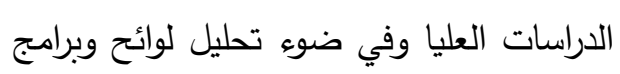
الدراسات العليا بأقسام الإعلام التربوي علي ولي

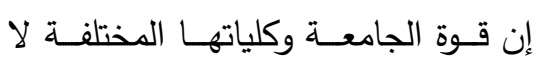

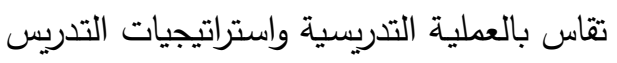

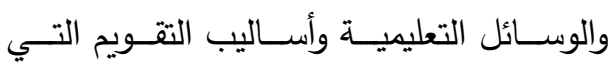
تستخدمها فحسب، بل إن الأهم من ذلك كله هو قدرتها علي البحث العلمي وتطوير برامجها

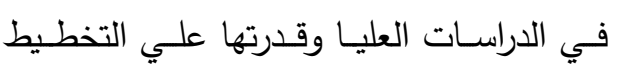

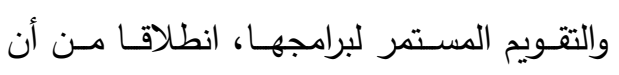

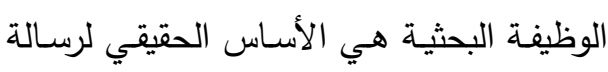

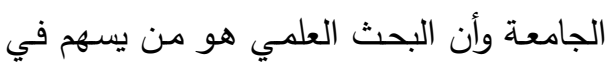

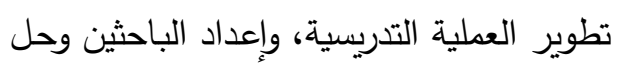
مشكلات المجتمع وفهم قضاياه. وتعد كليات التربية النوعية بتخصصاتها المختلفة واحدة من كليات الجامعة المعنية بتطوير برامجها في الدراسات العليا، ولا تأتي التئية عملية التطوير إلا من خلال تقويم برامجها بالدراسات العليا ومنها برنامج الإعلام التربوي التربي في إطار سعي هذه الكليات نحو تحقيق الجودة الإنال والرغبة في الحصول علي الاعتماد الأكاديمي، الجودي،

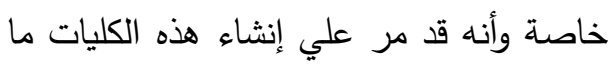

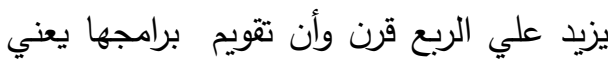

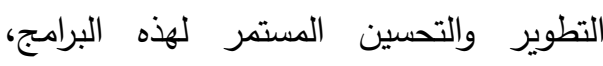
والوقوف علي جوانب القوة وتتميتها ونقاط لئن 
كليات الإعلام والآداب ومعهد الدراسات العليا للطفولة، والمعهد العالي للفنون المسرحية، وفي الغالب عزوف بعض المنتدبين عن المشاركة في التدريس في برامج الدراسات العليا بأقسام الإعلام التربوي نظرا لانشغالهم بالعمل بكلياتهم

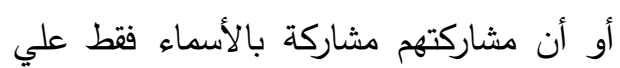

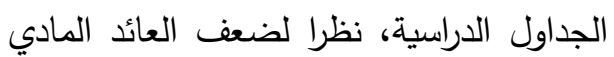
منها أو عدم وجود مخصصات مالية كافيه لبرامج الدراسات العليا وبعد المسافة، وتوجه ودود ماتهاته من هم في درجة أستاذ أو أستاذ مساعد المعينين بهذه الأقسام للعمل بالجامعات العربية

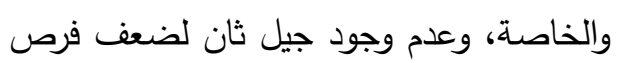

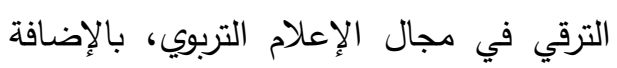
إلي أن بعض كليات التربية النوعية وفقا لنظام العمل الداخلي بها تمنع من هم في درجة لئل مدرس من المشاركة في التدريس بمرحلة الدراسات العليا، وقصر عملية التدريس علي من هم في درجة أستاذ وأستاذ مساعد، الأمر الذي حمل من هو في درجة أستاذ أو أستاذ مساعد عبء تدريس معظم مقررات مواد التخصص أو إثراك المدرسين في التدريس بالدراسات العليا لتخفيف هذا العبء. إن برامج الدراسات العليا بأقسام الإعلام

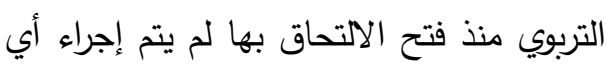

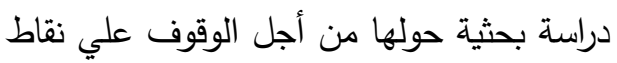

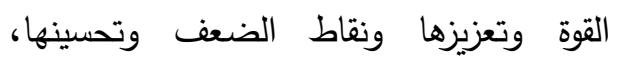
وأصبح دور هذه الأقسام منح الدرجات العلمية
اختلاف تخصصاته الثلاث (الصحافة، الإذاعة والتليفزيون التعليمي، المسرح التربوي). مشكلة الدر اسة وتساؤ لاتها: بدأت كليات التربية النوعية العمل في لانيا: نهاية الثمانينيات وبداية التسعينيات من القرن الماضي، وبدأت الدراسات العليا بأقسام الإعلام التربوي في بعض كليات التربية

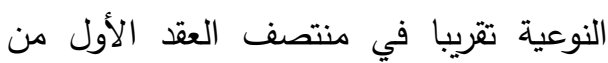
الألفية الثالثة، وأصبح التعجل في استحداث دراسات عليا بأقسام الإعلام التربوي ثمة تفاخر

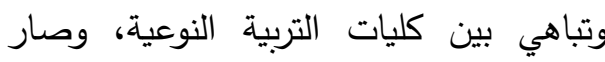
المعيار الرئيس لفتح الدراسات العليا بأقسام الإعلام التربوي وجود أستاذ أو أستاذ مساعد الترات معين علي تخصص من تخصصات الإعلام التربوي دون وجود تخطيط مسبق ووجود رؤية ورسالة وأهداف واضحة ومحددة ومعلنة لبرامج الإعلام التربوي بالدراسات العليا، ودون تحديد الاستراتيجيات وعدم وجود سياسة بحثيه، وتحديد لمواصفاته وتوصيف لمقرراته، وعدم توافر الإمكانات المادية والبشرية، ودون النظر

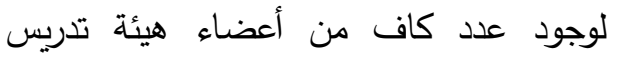
يحمل درجة أستاذ أو أستاذ مساعد يغطي حاجة هذه التخصصات، كما في كليات التربية النوعية (العباسية، المنصورة، دمياط، الزقازيق، طنطا، بورسعيد، أشمون، بنها، المنيا) فهذه الكليات بها ـ علي الأكثر حاليا ـ أستاذ أو لونيا،

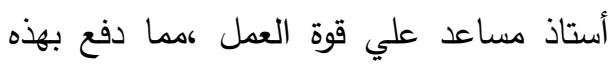

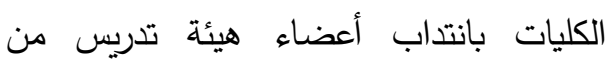




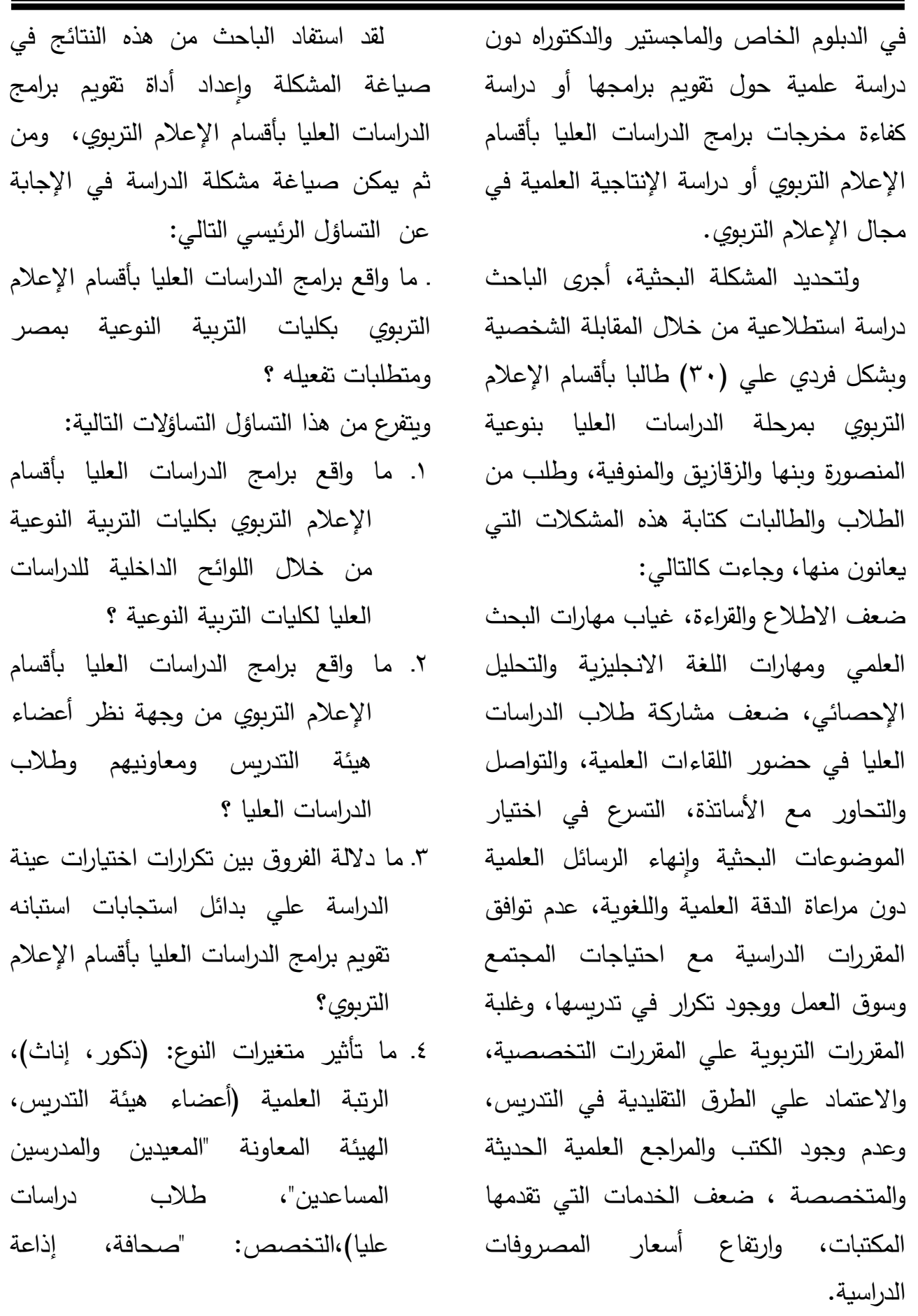




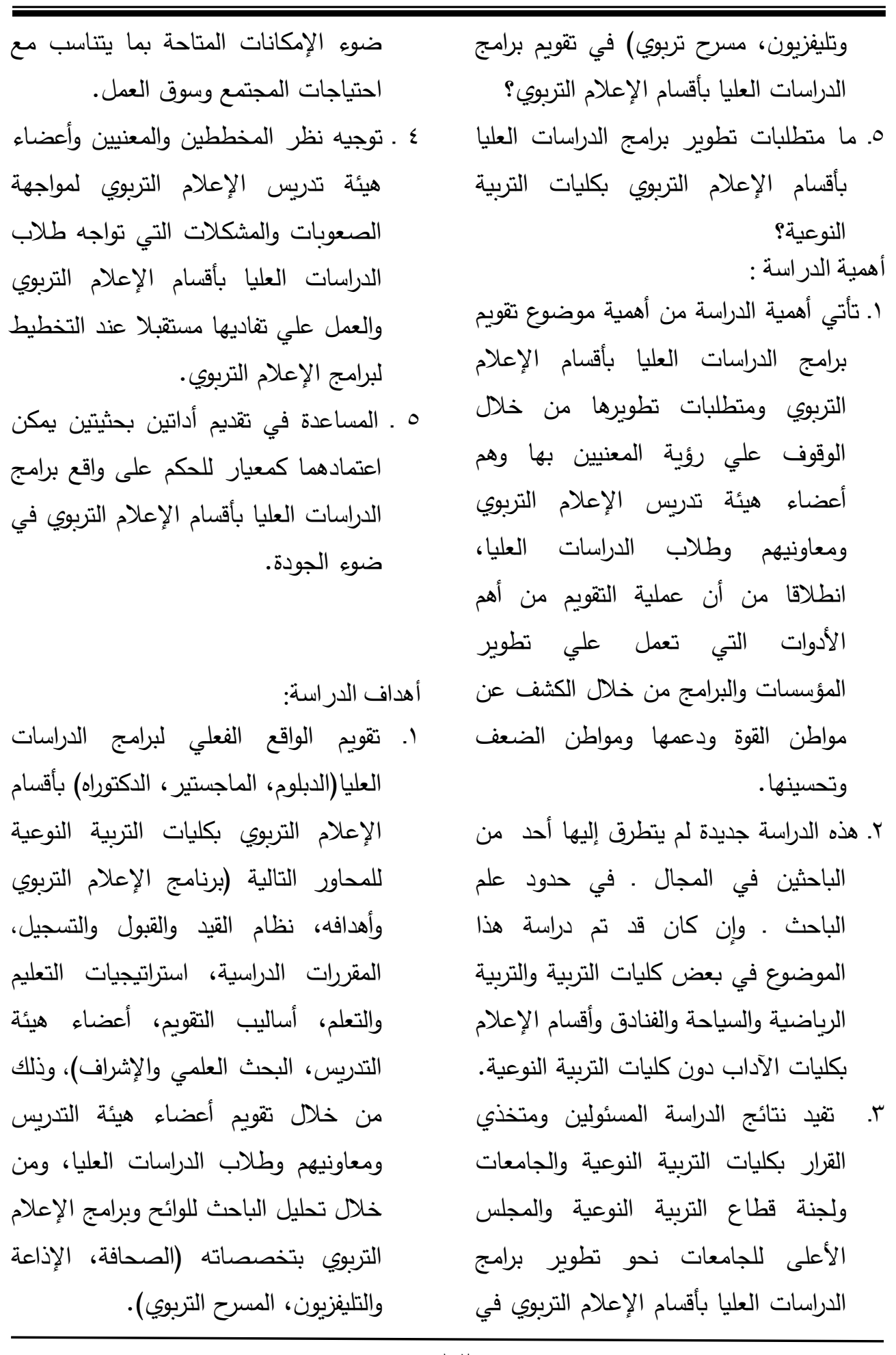


r. دراسة الفروق بين تكرارات اختيارات عينة ومعاونيهم وطلاب الدراسات العليا للمحاور

الدراسة علي بدائل استجابات استبانه السابقة.

تقويم برامج الدراسات العليا بأقسام الإعلام الد. الدراسات العليا بأقسام الإعلام التربوي:

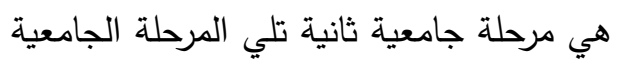

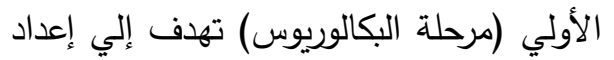

r. دراسة تأثير متغيرات (النوع، الرتبة العلمية،

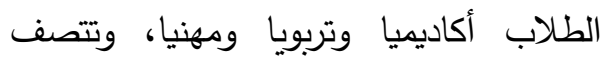

التخصص) علي تقويم برنامج الدراسات

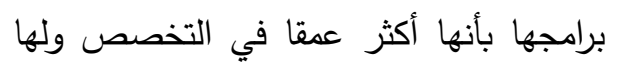
العليا بأقسام الإعلام التربوي.

شروط محددة للقبول والتسجيل، وتمنح درجات الدبلوم والماجستير والدكتوراه في تخصصات الإعلام التربوي (الصحافة المدرسية، الإذاعة

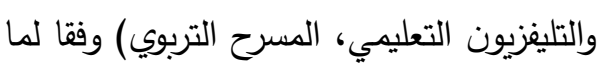
تحدده كل كلية.

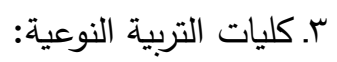

هي إحدى كليات الجامعات المصرية المعنية

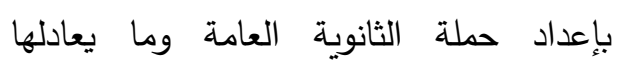
كخريجين تربويين أو إعدادهم للعمل بمهنة التعليم أو أي مهن أخري ، في تخين تخصصات نوعية مختلفة (الاقتصاد المنزلي، التربية

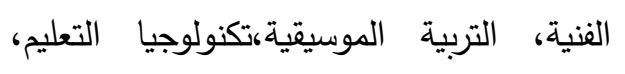
إعدام معلم الحاسب الآلي، الإعلام التربوي:

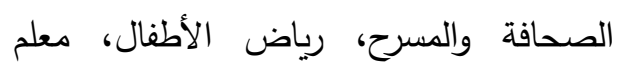
الفصل الواحد، العلوم التربوية والنفسية)، تماشيا مع احتياجات سوق العمل ولديه مهارات البحث العلمي ،كما تستخدم كافة لئيات إمكانياتها المادية والبشرية في خدمة البحث العلمي والمجتمع وتتمية البيئة وإجراء البحوث في مجالات التخصصات المختلفة. حدود الدر اسة:

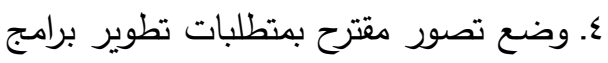

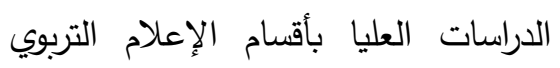
بكليات التربية النوعية.

$$
\text { 1 مصرفها الباحث إجرائيا علي النحو التالي: }
$$

هو عملية تشخيصية تهدف إلي بيان جوانب القوة والضعف في برامج الدراسات العليا بأقسام الإعلام التربوي بكلية التربية النوعية (الدبلوم

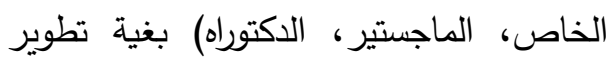
هذه البرامج من أجل تحقيق أهدافها والحكم

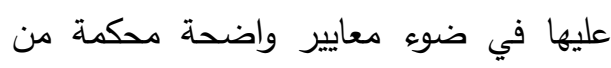
خلال نموذج أو أداة التقويم المقترحة. وتم تتاول عملية التقويم في مبحثين الأول: دراسة وتحليل اللوائح الداخلية والمقررات لكليات التربية النوعية فيما يخص برامج الإعلام التربوي، الثاني : إجراء دراسة ميدانية

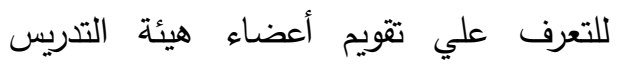


ويعطونهم تغذية راجعة ودعم لمواصلة

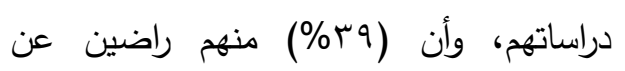
الإشراف علي رسائلهم للماجستير، وتزيد هذه وانه النسبة إلي (r£\%) في المراحل النهائية من الإشراف.

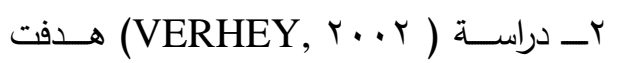
الدراسة التعرف علي اتجاهات طلاب الدراسات العليـا في جامعـة SFSU ، وأجريــت الدراسـة

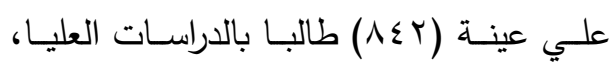
وكثفت نتائج الدراسة أن (9\% (1\%) من الطلاب

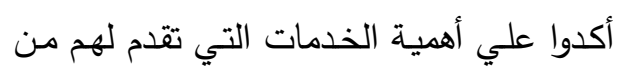

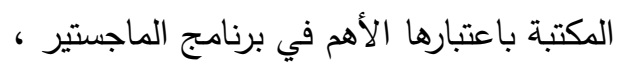

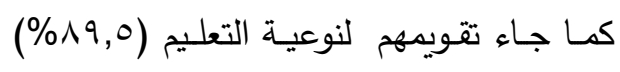

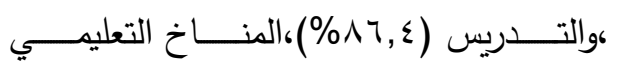

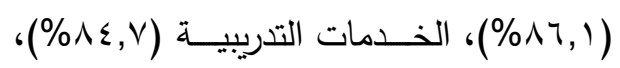

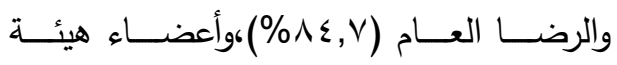

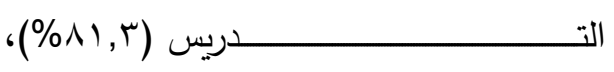

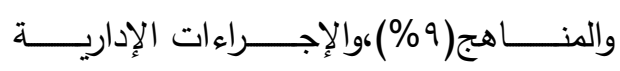

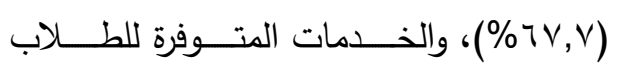

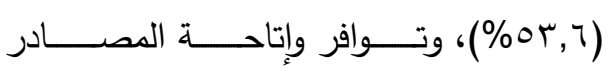
.(\%r^, 9$)$

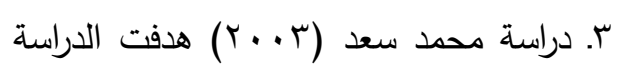
إلى رصد إثكاليات التأهيل والتدريب في أقسام الإعلام بالجامعات الإقليمية ، من خلال مسح

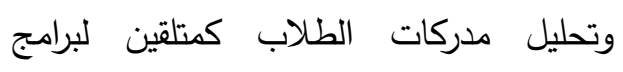

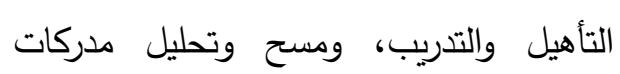
أعضاء هيئة التدريس ومعاونيهم كمنفذين لتلك ولتي
1. الحدود الموضوعية:

تتناول الدراسة في جانبها المعرفي ماهية التقويم وأهميته وأنواعه ، والدراسات العليا بكلية التربية النوعية،وأهدافها والبرامج التي تمنحها والتهات

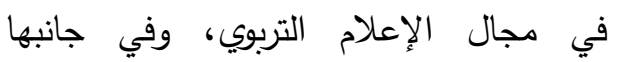
المنهجي تحديد منهجها وعينتها وأدواتها ونتائجها التحليلية والميدانية ووضع تصور تهور مقترح بمتطلبات تطوير الدراسات العليا بأقسام الإعلام التربوي. ז. الحدود المكانية : كليات التربية النوعية في مصر (المنصورة،

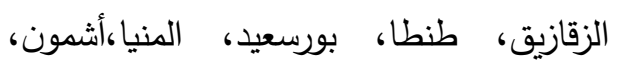
العباسية، بنها)، والتي بها دراسات عليا في بورئي مجال الإعلام التربوي.

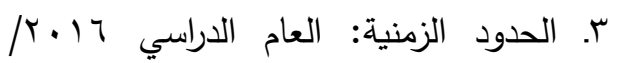
. r.IV

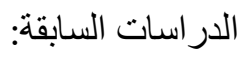
ا. دراسة (TRICE, 2002) هدفت الدراسة إلي تقويم برامج الدراسات العليا في جامعة

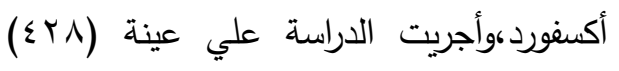

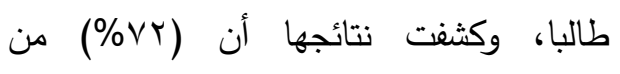
الطلاب راضين عن الخبرة الأكاديمية التي تلقوها من هذه البرامج ، كما بلغت نسبة الرضا

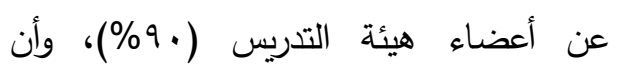

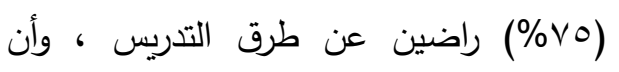

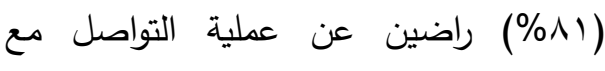

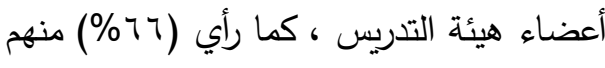
أن أعضاء هيئة التدريس يساعدون الطلاب 


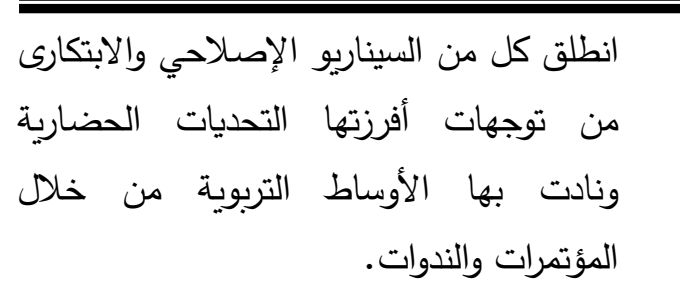

هـ دراسـة عليـان الحـولي وسـناء أبـو د دقـة

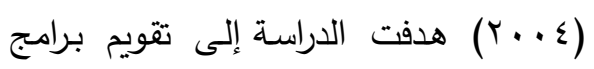

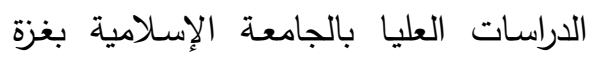

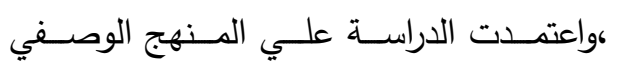
التحليلي لعينة (91) خريجا من خريجي برامج

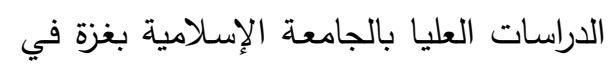
كليات الثربعة وأصول الدين والتربية والعلوم الذين أتموا إعداد رسائلهم العلمية واستوفوا إجراءات المناقثة، أظهرت نتائج الدراسة أن برامج الدراسات العليا بالجامعة الإسلامية تلبي

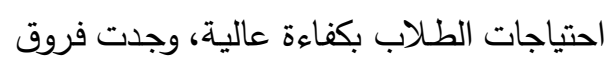
ذات دلالة إحصائية في محور تلبية برامج الدراسات العليا لحاجات الطلبة تعزى لمتغيري

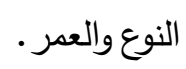

ד. دراسة (Gessica Muller,2006) هدفت الدراسة إلي تقييم برامج الدراسات العليا في كلية ميديساين بجامعة كاليفورنيا بالولايات المتحدة الأمريكية، واعتمدت الدراسة علي لينة

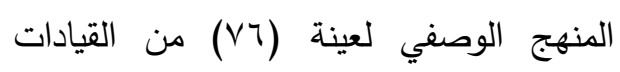

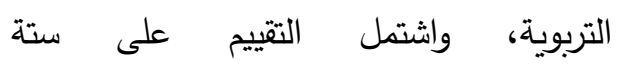
محاور (نظريات التعلم، أساليب التعلم والتعليم، التئمل

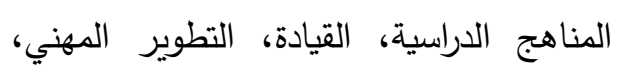

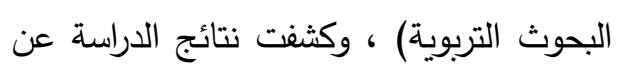

البرامج ورصد دور أعضاء هيئة التدريس ومعاونيهم في التوجيه المهني، والتعرف علي التوجهات المهنية للطلاب، وتوقعاتهم للمستقبل

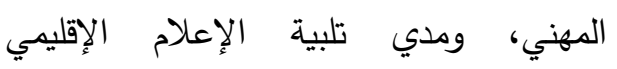
لطموحاتهم، وكثفت نتائج الدراسة أن التعجل

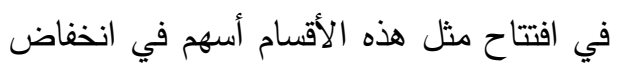

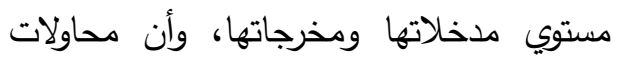
تطوير برامج التأهيل والتدريب تقف عند عند حداتيان تعديل اللوائح علي نحو يلبي التوازنات،وجلب أجهزة ومعدات دون توفير الكوادر القادرة علي لعي لتولي

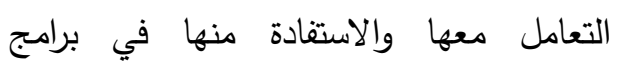
التدريب.

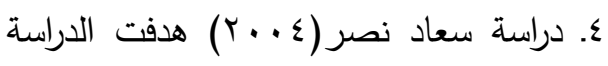

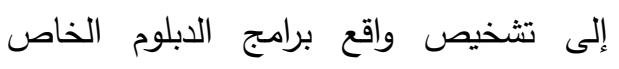
بكليات التربية من حيث: الأهداف ووضوحها، والترتيبات الإدارية ومدى تيسيرها للعمل، ونظم القبول، ونظم وخطط الدراسة، وأعضاء هيئة

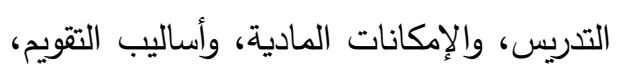
ونوعية المخرجات، والتحديات التي تؤثر على والانى برامج الدبلوم الخاص بكليات التربية،واعتمدت وندئ

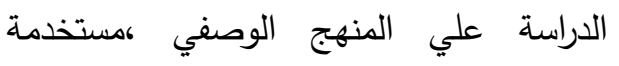
أسلوب السيناريو وتوصلت الدراسة إلى بناء

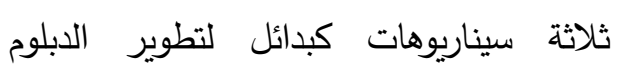
الخاص في التربية، وهى السيناريو الامتدادي لاديوني

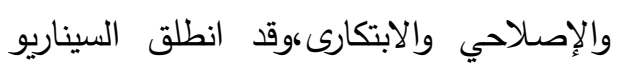
الامتدادي من الوضع الراهن للدبلوم الخاص

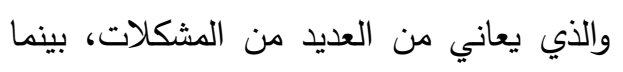


العليا (الدبلومة المهنية) بكليات التربية في مصر في ضوء الاتجاهات العالمية المعاصرة، لكاتيات التربية

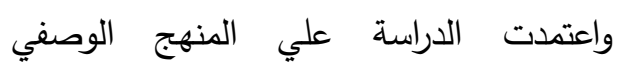
مستخدمة أداة تحليل المحتوى للمناهج الدراسية

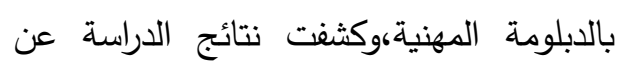
تأرجح الاتجاهات الثلاثة (العزلي، العزلي في

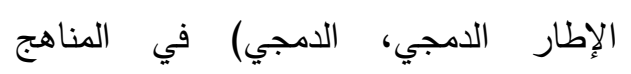
الدراسية، وانعدام تواجد الاتجاه الدمجي الثامل لإمل في جميع المناهج الدراسية إلا بنسبة نادرة

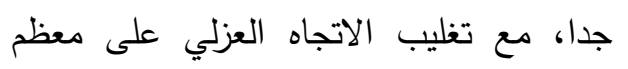

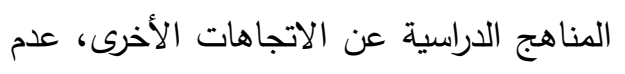

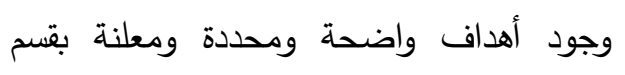

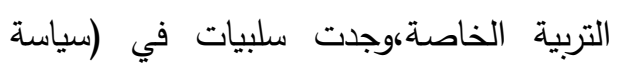
قبول الطلاب، المناهج الدراسية ، التربية العملي، طرق التدري، هيئة التدريس ،التقويم

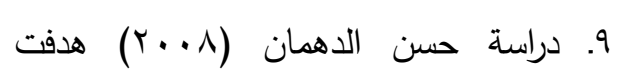
الدراسة التعرف علي أراء واتجاهات الأساتذة في تقييم السياسات التعليمية والإدارية للدراسات العليا بكليات جامعة v أكتوبر المتواجدة بمدينة مصراته بدولة ليبيا . جامعة مصراته حاليا . واعتمدت الدراسة علي منهج دراسة الحالة لعينة (rr) أستاذا للعلوم التطبيقية والإنسانية، الليبيين وغير الليبيين، وكثفت نتائج الدراسة

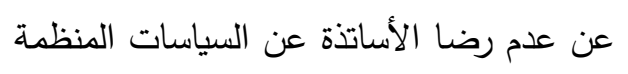
للدراسات العليا لقلة اهتمام الجامعة بالتقييم

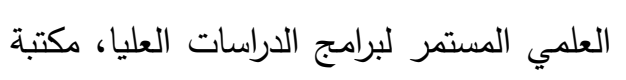

أهمية البرامج المقدمة للقيادات التربوية في زيادة إنتاجية البحوث العلمية، وإكسابهم المعارف والمهارات والاتجاهات الجديدة، وجدت بعض المعوقات التي تعوق هذه البرامج

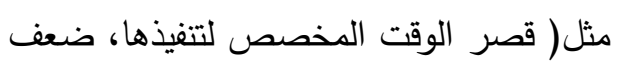
عملية التواصل مع خريجي البرنامج)، وأوصت لوتهن

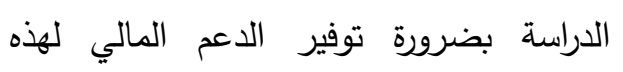
البرامج، والتقويم المستمر لها.

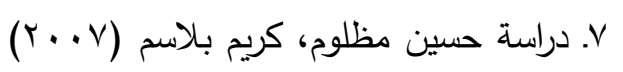
هدفت الدراسة إلي تقويم برامج الدراسات العليا من وجهة نظر الطلبة، واعتمدت الدراسة علي لئي

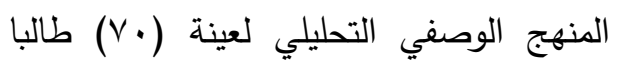
وطالبة بمرحلتي الماجستير والدكتوراه بكلية

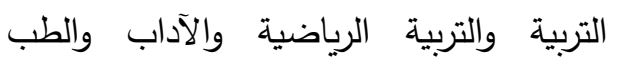

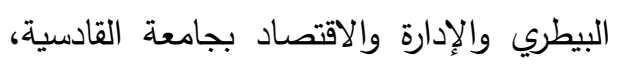
وكثفت نتائج الدراسة عن وجود فروق ترجع لمتغير الجنس لطلبة الماجستير في محوري

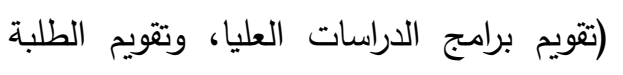
للدراسات العليا) دون الدكتوراه، كما وجدت لترات فروق ترجع لمتغير الوظيفة لطلبة الماجستير لمات في محور (تلبية البرامج لحاجات الطلبة) دون

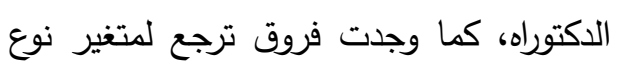
الدراسة لطلبة الماجستير في نفس المحور دون الاكتوراه.

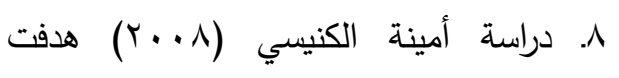
الدراسة إلي تقويم المناهج الدراسية والتربية العملية في مجال التربية الخاصة بالدراسات 
نتائج الدراسة عن وجود قصور في البرنامج .

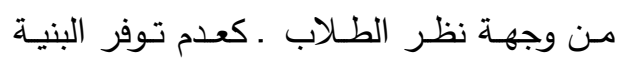

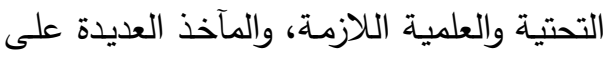
العملية التعليميـة والبحثية، وقد عبر الطـلاب عن ذلك بدرجـة رضـا "متوسطة"، بينمـا جـاء

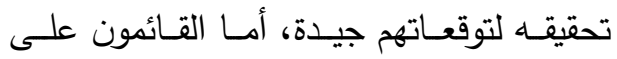

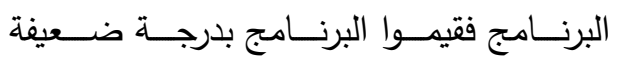
ومسـتوي رضــا مــخفض، واتجاهـات سـلبية نحوه، وأبدوا عليه مآخذ عديدة لعدم التخطيط

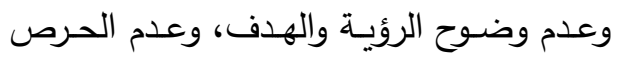

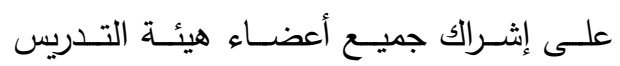
والمختصين والممارسين في تصميمه، مطالبين

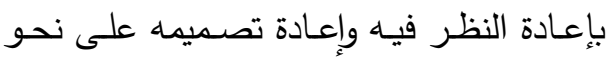
علمي بما يستوعب متطلبات العصر . باعل

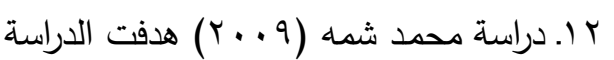
إلـي بيـان أثر التفاعل بـين مـدخلين لتصـميم

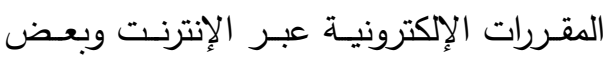

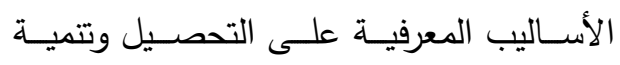
مهارات التفكير العليا لطلاب الدبلوم الخـاص التص في التربيـة، واعتمدت الدراسـة علي المنهجين التكنولوجي في تطوير المنظومـات التعليميـة،

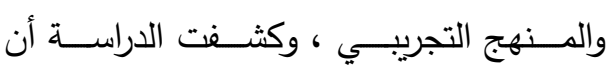

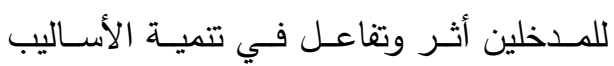
المعرفيـة والتحصيل و تتميـة مهارات التفكير العليا لطلاب الدبلوم الخاص في التربية.
الجامعة غير غنية بالمراجع العلمية الحديثة،

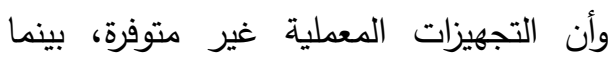
جاءت المقررات ذات طابع تطبيقي وأن عددها مناسب، وأن مواضيع الرسائل العلمية تخدم قضايا المجتمع، المرتبات عادلة،تثجع الجامعة الأساتذة لحضور المؤتمرات العلمية الخارجية ودعوة الزوار للتواصل مع الأساتذة

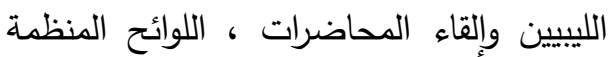
جيدة ، وأن الجامعة في حاجة للإشراف المشترك.

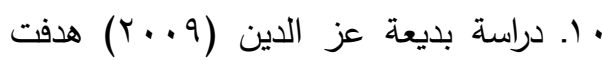
الدراسة إلي تقويم برنامج الماجستير بكلية التربية جامعة الفاشر بالخرطوم بجمهورية

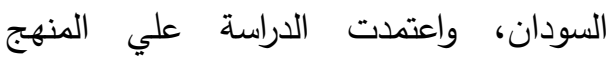
الوصفي التحليلي، لعينة (00) دارسا، وكثفت

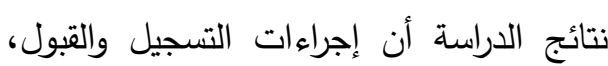

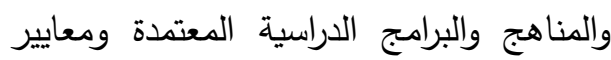
تقويم وإعداد البحوث لها دور إيجابي في برنامج الماجستير ، لكن البيئة البحثية والدراسية ضعيفة ببرنامج الماجستير بكلية التربية.

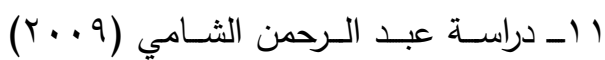
هدفت الدراسـة إلى التعرف على واقع برنـامج

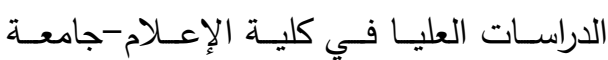

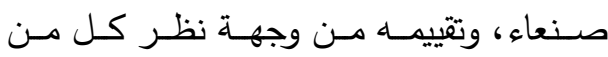
الطلاب والقائمين عليه، وذلك بالاعتمـاد على وجى

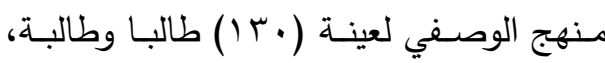
(7 ( ) من القائمين على هذا البرنامج، كثفت لون 


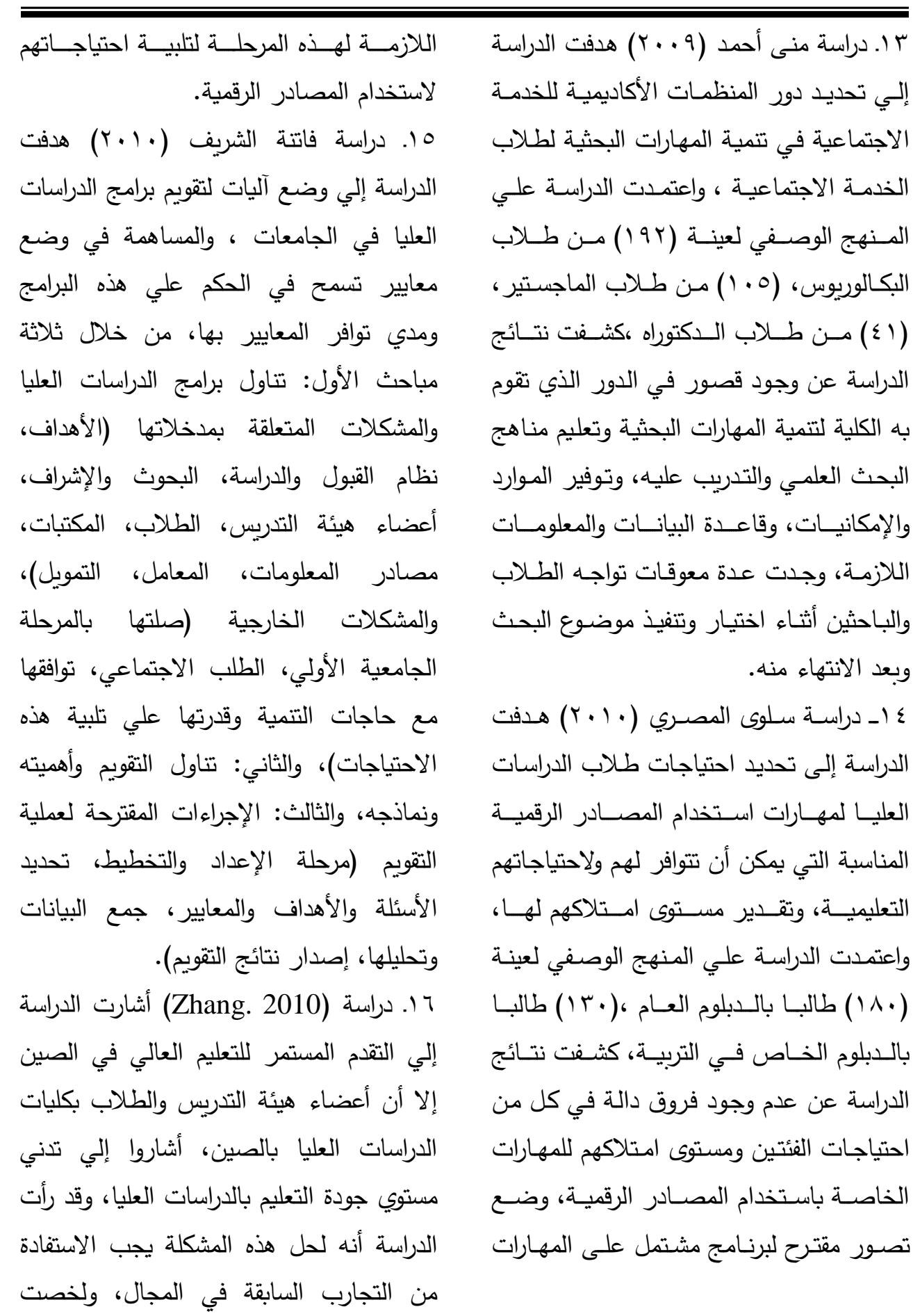




\begin{tabular}{|c|c|}
\hline الأهداف. الطلاب علي محاور الاستبانه سوي محو & 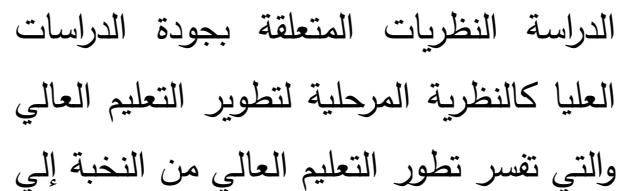 \\
\hline الدراسة إلى التعرف علي المشكلات المهنيا & تعليم الجماهير، ونظرية القانون الداخلي \\
\hline لأعضاء هيئة تدريس الإعلام التربوي & والخارجي والتي تفسر الجودة في ضوء العلاقة \\
\hline الصحافة والمسرح وعلاقتها بجودة الأداء & بين التعليم والتتمية الاجتماعية من جانب \\
\hline واعتمدت الدراسة علي المنهج الوصفي لعيi & والعوامل الخارجية المؤثرة في الفرد، ونظرية \\
\hline (†^) عضوا من أعضاء هيئة تدريس الإعلاد & الوظائف الاجتماعية لمؤسسات التعليم العالي \\
\hline التربوي ومعاونيهم بكليات التربية النوعية & والتي تثير إلي العلاقة بين الجامعات \\
\hline ت نتائج الدراسة عن وجود علاقة ارتباطيا & والمجتمع. \\
\hline بين المشكلات المهنية وتأثر جودة أداء & V ا. دراسة محمد عيسي، وليد أبو المعاطي \\
\hline أعضاء هيئة تدريس الإعلام التربوي بمعدل & 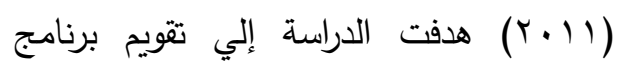 \\
\hline عال ومرتفع يصل إلي (r N \%)، ليس & الدراسات العليا الماجستير بكلية التربية جامعة \\
\hline لمتغيرات (النوع، الدرجة العلمية، سنوات الخبرة & الطائف من وجهتي نظر أعضاء هيئة التدريس \\
\hline بالوظيفة) تأثير علي درجتي وجود المشكلات & وطلبة الدراسات العليا، واعتمدت الدراسة علي \\
\hline المهنية وجودة الأداء، في حين وجد تأثير & المنهج الوصفي لعينة (Yl) عضو هيئة \\
\hline لمتغير التخصص علي مشكلات خدما & تدريس، (·^) طالبا، وكثفت نتائج الدراسة \\
\hline المجتمع وتتمية البيئة لصالح الأعضاء & عن وجود قصور في برنامج الماجستير من \\
\hline تخصص المسرح ، وجدت فروق ترجع لمتغير & حيث سياسة القبول والتسجيل واللوائح الجامعية \\
\hline الكلية في وجود المشكلات وتأثر جودة الأداء & وأهداف البرنامج والمقررات الدراسية ومحتواها \\
\hline لصالح كلية التربية النوعية (أشمون، طنطا، & واستراتيجيات التعليم والتعلم وأساليب التقويم \\
\hline بنها، المنصورة، الزقازيق، العباسية، كفر & والإرشاد الأكاديمي والخدمات والتسهيلات \\
\hline ) علي الترتيب • ( ) & البحثية، وجدت فروق في هذه المحاور لصالح \\
\hline 9 1. دراسة شادية تمام (r (r) هدفت & أعضاء هيئة التدري، بينما اتفق الأعضاء \\
\hline الدراسة إلي تحديد الأسس التي تقوم عليها & والطلاب علي كفاءة هذه المحاور، لا توجد \\
\hline معايير الجودة في برامج الدراسات العليا & فروق ترجع لمتغير النوع (ذكور، إناث) بين \\
\hline & \\
\hline
\end{tabular}


التعليمية، المتعلقة بالتقويم والامتحانات، البرامج الدراسية والمقررات، الأساتذة والزملاء) علي الترتيب، وجدت اختلافات حول مدي لني شيوع استراتيجيات حل المشكلات حيث جاءت إستراتيجية (رد الفعل، التوجه العام للمشكلة،

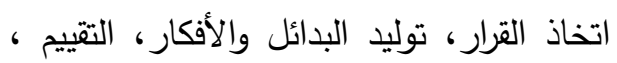
تحديد المشكلة) علي الترتيب، وجدت فروق في استراتيجيات حل المشكلات ومواجهة الضغوط النفية والأكاديمية لصالح التطبيق البعدى، لا لاتئل توجد فروق ترجع لمتغيري الجنس والتخصص.

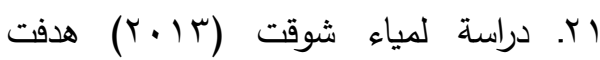
الدراسة إلي تقديم رؤية مستقبلية لتطوير لتولية منظومة الدراسات العليا بكلية الاقتصاد لاديه المنزلي جامعة المنوفية لتحقيق الجودة الثاملة من خلال دراسة خبرات بعض (الدول الولايات المتحدة الأمريكية والمملكة المتحدة واستراليا

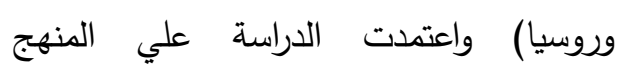
الوصفي من خلال استطلاع رأى الطلاب

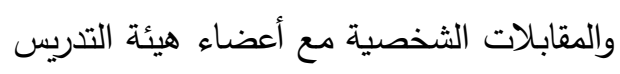
بمختلف الأقسام وتحليل اللائحة الداخلية للدراسات العليا بكلية الاقتصاد المنزلي ، وتم وضع رؤية مستقبلية لتطوير منظومة الدراسات العليا بكلية الاقتصاد المنزلي جامعة المنوفية

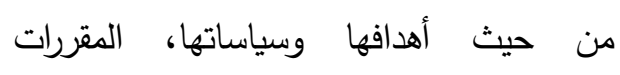

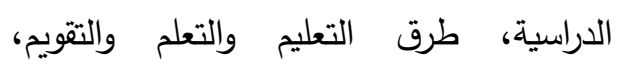
التجهيزات والتسهيلات المختلفة ، الأبحاث العلمية ، طلاب الدارسات العليا.
هذه المعايير، واعتمدت الدراسة علي المنهج الوصفي التحليلي لعينة (ro) من طلبة الدبلوم الخاصة- نظام العام ونظام العامين- بمعهد الدراسات التربوية، كثفت نتائج الدراسة عن عدم توافر معايير جودة برامج الدراسات العليا في مجال الأهداف، في حين توافرت المعايير بمحتوى برامج الدراسات العليا التربوية وفقا فتاتيات لوجهة نظر الطلاب.

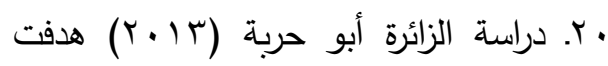
الدراسة إلى التعرف علي مدى فعالية برنامج لتتمية بعض استراتيجيات حل المشكلات لمواجهة الضغوط النفسية والأكاديمية لطلبة الدراسات العليا بدولة ليبيا، واعتمدت الدراسة على المنهجين الوصفي والتجريبي لعينة

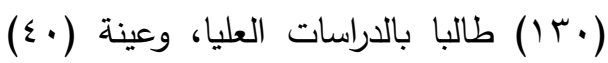
طالبا وطالبة قسمت مناصفة لرجموعتين تجريبية وضابطة من الطلاب الذين حققوا

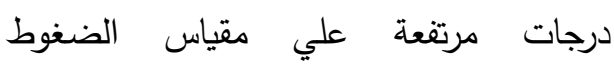
الأكاديمية والنفسية، ومنخفضة علي مقياس استراتيجيات حل المشكلات، كثفت نتائج الدراسة عن وجود اختلافات جوهرية بين استجابات طلبة الدراسات العليا حول مدي جودي شيوع الضغوط النفسية والأكاديمية، فالضغوط الضوات الفيات النفسية الأكثر شيوعاً هي الضغوط الضغوط (البيئية،

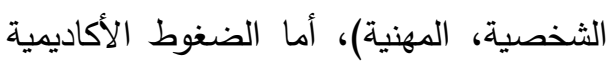
فجاءت الضغوط المتعلقة (بالمكتبات والمعامل ومصادر المعلومات، طرائق التدريس والوسائل 
التدريس، والإمكانات المادية، وأساليب التقويم، ونوعية المخرجات، واعتمدت الدراسة علي المنهج الوصفي، وكثفت نتائج الدراسة عن أن نظام الدراسات العليا بكلية التربية جامعة التهاتية المنوفية لا يحقق أهدافه وأن الأهداف تحتاج إلى إعادة صياغة لتسهيل قياسها إجرائيا، وأن إجراءات القبول تحتاج إلى مراجعة وتطوير، إعلى لتهنيل وتخفيض عدد الإجراءات الروتينية ومدتها،

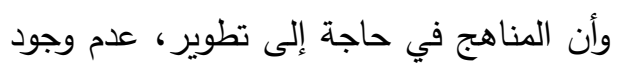
الخدمات والتسهيلات للأبحاث والدراسات العليا

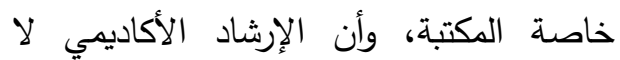
يحقق أهدافه، عدم استخدام الطرق الحديثة في التدريس. צ. r. دراسة حمزة الرياشي وعلي الصغير

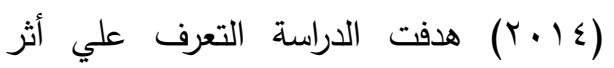
برنامج تدريبي مقترح في تتمية مهارات البحث

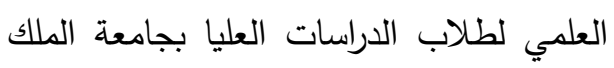
خالد، وتضمن محتوي البرنامج (التعريف بالبحوث وأنواعها، ومشكلة البحث، وخطواته،

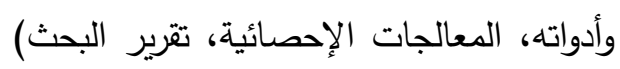
واستغرق البرنامج (Y) (Iادة) ساعة علي مدار أربعة أيام، واعتمدت الدراسة علي المنهجين

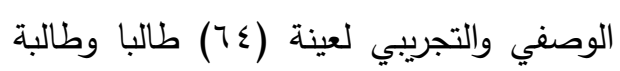
بكلية التربية بيرنامجي الماجستير والدكتوراه

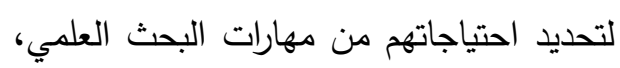
وفي إطار ذلك تم تطبيق البرنامج التدريبي علي عينة (乏) طالبا مسجلين بيرنامج r r. دراسة مروة بكر (r (r) هدفت الدراسة إلي التعرف علي الهدر التعليمي ومظاهره والعوامل المؤدية له بالدراسات العليا بجامعة

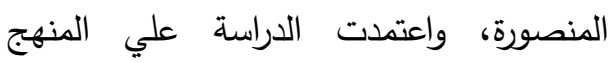

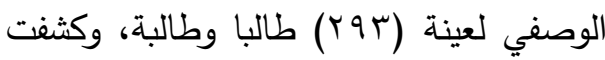
نتائج الدراسة أن الدراسات العليا بجامعة المنصورة تعاني من مشكلات عديدة منها جمود برامج الدراسات العليا، قلة البعثات الداخلية والإشراف المشترك، الموارد المالية والمشاركة في المؤتمرات العلمية، المشاريع الدولية الممولة من خارج الجامعة، الدعم

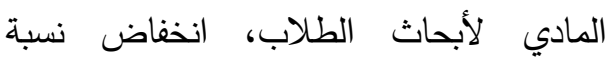
المقيدين بالدراسات العليا إلي المقيدين بالمرحلة الجامعية، ارتفاع نسبة بقاء طالب الدراسات

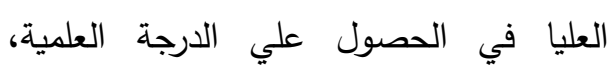
انخفاض العائد المادي لأعضاء هيئة التدريس

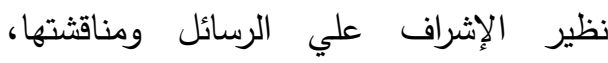
ضعف ارتباط برامج الدراسات العليا بمتطلبات سوق العمل، ضعف المردود المعنوي من قبل المؤسسات المجتمعية لطلاب الدراسات العليا، زيادة الأعباء الأسرية والاجتماعية لهم.

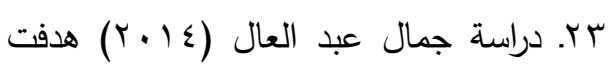
الدارسة إلى تشخيص الواقع الفعلي لبرامج

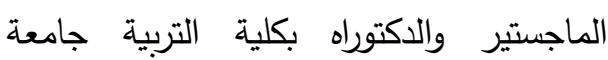

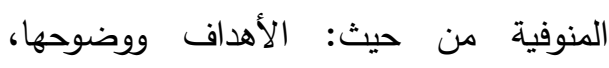
والترتيبات الإدارية ومدى تيسيرها للعمل، ونظم القبول والخطط الدراسة، وأعضاء هيئة 
ستة سيجما ومبادئها وأهدافها وخطواتها وأدواتها ومنطلبات تفعيلها بكلية التربية، كثفت نتائج الدراسة عن أن كلية التربية جامعة المنصورة تفتقد تطبيق أي نموذج في إدارة الجودة الثاملة، وأوصت الدراسة بأهمية تطبيق مبادئ ستة سيجما بكلية التربية لإدارة الجودة الثاملة

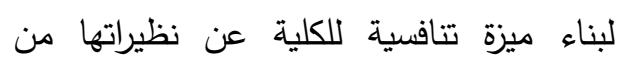
الكليات المماثلة، ومساعدة المسئولين في اتخاذ القرارات المبنية علي الحقائق والمعلومات.

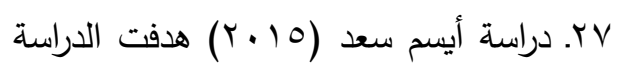
إلي التعرف علي مشكلات تطبيق نظام الساعات المعتمدة في الدراسات العليا بمعهد الدراسات والبحوث التربوية بجامعة القاهرة ووضع الحلول لها، واعتمدت الدراسة علي لهني المنهج الوصفي لعينة (•r) عضو هيئة

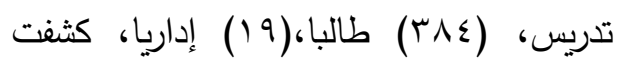
نتائج الدراسة عن وجود مشكلات (إدارية وتتظيمية، نظام الساعات المعتمدة ولوائحه،

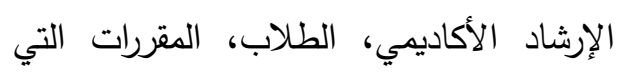

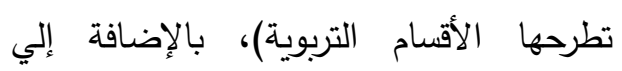

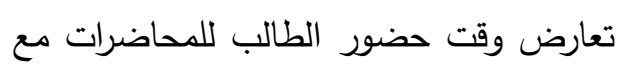

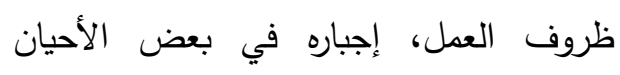
لاختيار المقررات التي يكتمل العدد بها، وطرح

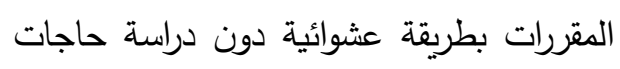
الطلاب، الافتقار للكفاءات الإدارية المدربة

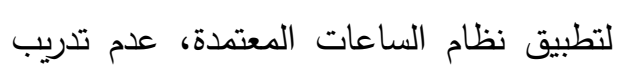
أعضاء هيئة التدريس علي النظام قبل تطبيقه،
الدكتوراه، كثفت نتائج الدراسة عن استفادة طلاب الدراسات العليا من البرنامج التدريبي بنسبة (ع 9\%)، أظهر الطلاب درجة عالية من

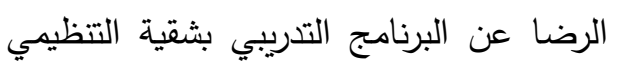
والعملي. ه. دراسة خالد عبد النبي (ع ا.ب) هدفت الدراسة إلي التعرف على واقع برامج الدراسات

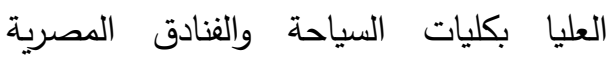
والتحديات المواجهة، واعتمدت الدراسة علي المنهج الوصفي، وكثفت نتائج الدراسة أن

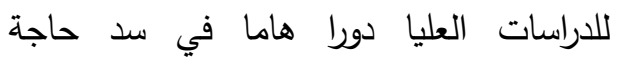
المجتمع من الكوادر البشرية المتخصصة في دلي مختلف المجالات من أعضاء هيئة تدريس وعلماء ومفكرين وخبراء، وحل مشاكل التتمية، مناء

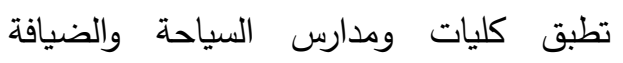

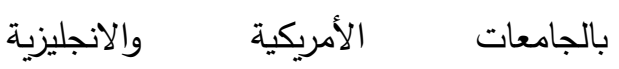
نظامي(الإثراف الموحد، الساعات المعتمدة)، وتتقسم الدرجات العلمية إلي درجة الدبلوم والتي تتقسم إلى مرحلتين ( شهادة الدراسات العليا، لتهات

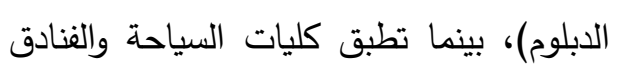
في مصر نظامي (الإشراف المتعدد، الساعات المعتمدة) في بعض الكليات.

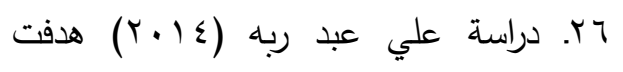
الدراسة إلي وضع تصور مقترح لتطبيق إستراتيجية ستة سيجما لتحقيق الميزة التتافسية بكلية التربية جامعة المنصورة، واعتمدت الدراسة علي المنهج الوصفي التحليلي لمفهوم 
وجهة نظر طلاب وطالبات الموازي الملتحقين به بكلية العلوم الاجتماعية بجامعة الإمام محمد بن سعود الإسلامية بالمملكة العربية

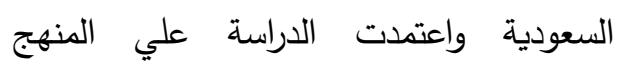

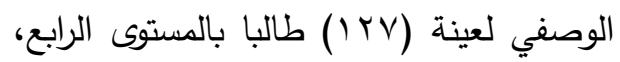
كثفت نتائج الدراسة عن موافقة أفراد الدراسة بدرجة ضعيفة على برنامج ماجستير الإدارة

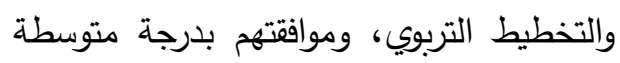
على كل من (المقررات الخاصة بيرنامج الماجستير، عضو هيئة التدريس)، وموافقتهم بدرجة ضعيفة علي كل من تجهيزات وواقع برنامج ماجستير الإدارة والتخطيط التربوي.

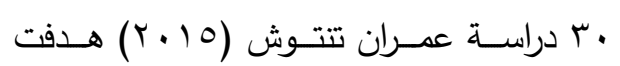
الدراسة التعرف علي مصـادر الضغوط النفسية لطلبـة الدراسـات العليـا (مرحلــة الماجسـتير)

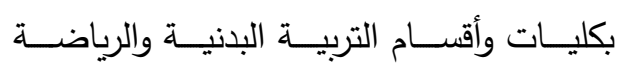
بالجامعـات الليبيـة، واعتمـدت الدراســة علـي ليـي المنهج الوصـفي لعينـة قوامهـا (ب9 (19) طالبـاً

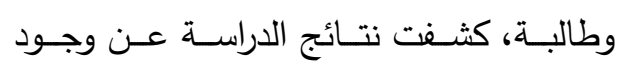

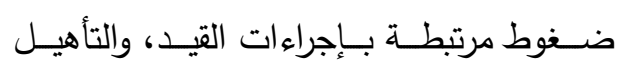

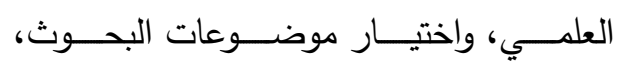

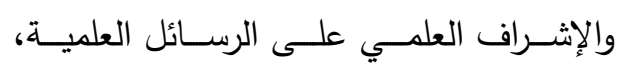

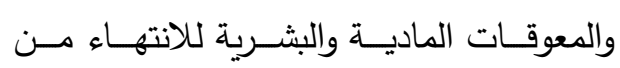

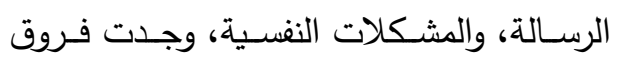

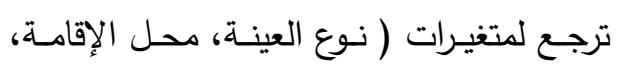

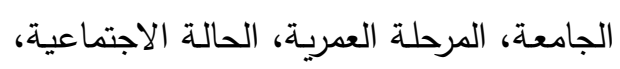

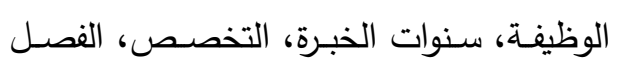

وعدم وجود عدد كاف منهم لتدريس المقررات الاختيارية، افتقار الإرشاد الأكاديمي للتنظيم، وعند

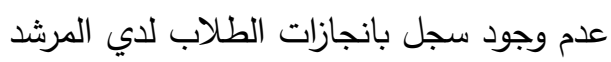

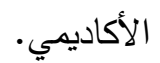

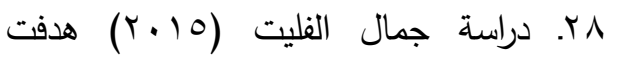
الدراسة إلي التعرف علي دور البحوث التربوية

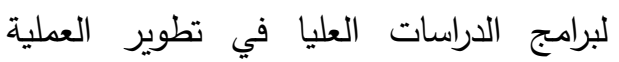
التعليمية في محافظات غزة ومقترحات تفعيله لتروليه والتي تمثلها رسائل الماجستير في تخصصات فئس أصول التربية وعلم النفس والمناهج وطرق التدريس، واستخدمت الدراسة المنهج الوصفي ولني لعينة (^^) مشرفا جامعيا ومسئولا من وزارة التربية والتعليم العالي، كثفت نتائج الدراسة أن

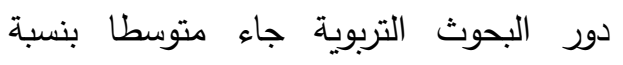

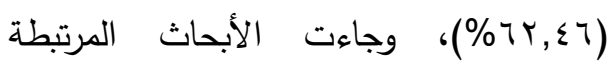
بالإدارة المدرسية في الترتيب الأول يليه الأبحاث المتصلة بمحور المناهج، ثم الأبحاث

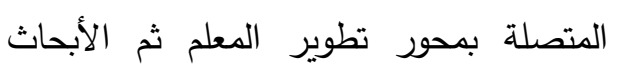

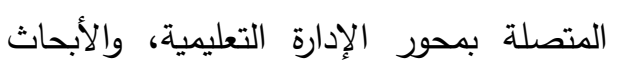
المتصلة بمحور تحسين مستوي المتعلم في الترتيب الخامس، عدم وجود فروق بين تقديرات المشرفين علي البحوث التربوية والقائمين علي العملية التعليمية نحو واقع ودور البحوث التربوية في تطوير العملية التعليمية.

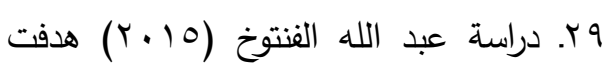
الدراسة إلى تقويم برنامج ماجستير الإدارة

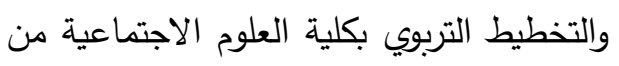


العلمي، أوصت الدراسة بضرورة إعداد برامج لتعزيز مستوى الوعي المعلوماتي لديهح.

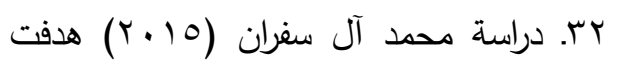
الدراسة إلي تقويم برامج الدارسات العليا بكلية

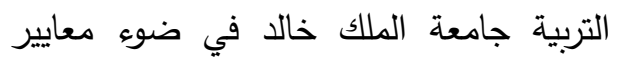
الجودة والاعتماد الأكاديمي للمحاور (مواصفات البرنامج، التعليم والتعلم، إدارة البرنامج، خدمة التهادي

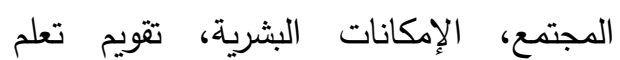

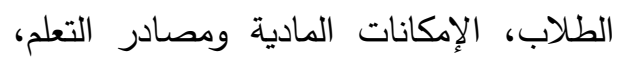

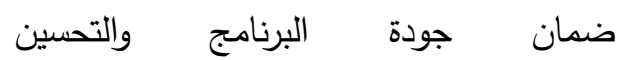
المستمر،اللوائح والنظم التعليمية)، واعتمدت البرنيج الدراسة علي المنهج الوصفي التحليلي لعينة

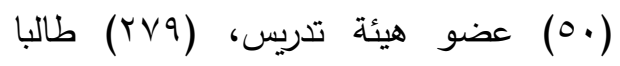
وطالبة، كثفت نتائج الدراسة أن معايير الجودة تُوبن تحقتت بدرجة متوسطة وعالية من وجهة نظر كمان

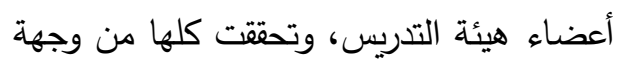
نظر الطلاب، وجدت فروق في معايير الجودة

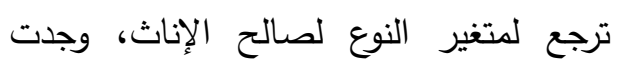
محاور تحتاج إلي تطوير كالمقررات الدراسية والتوازن في الجوانب النظرية والتطبيقية، والتزام

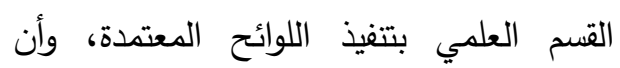
البرنامج ذو نظام فعال لقبول تظلمات الطلاب

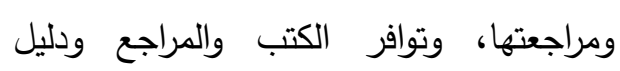
معتمد، وتوافر تخصصات أعضاء هيئة واتئ التدريس مع المقررات، وأن البرنامج يلبي

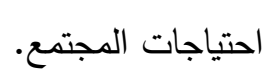

الدراسي) في مصـادر الضـغوط النفسية لطلبة

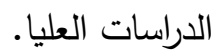
اس. دراسة لمى عبد الرازق، ثناء حمودي

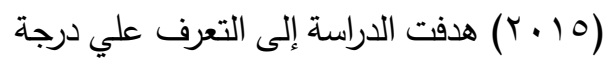
الوعي المعلوماتي لطلبة الماجستير في جامعتي محافظة الزرقاء والجامعة الهاشمية في الأردن،

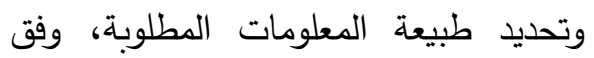
مؤشرات أداء المعيار الأول من معايير الوعي

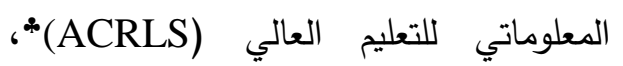
واعتمدت الدراسة علي المنهج الوصفي التحليلي لعينة (ع باع) طالبا من الجامعتين، وكثفت نتائج الدراسة عن وجود وعي معلوماتي بدرجة عالية لدى طلاب الدراسات العليا تمثل في قدرتهم على فهم الحاجة المرجوة من بن

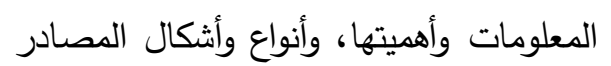

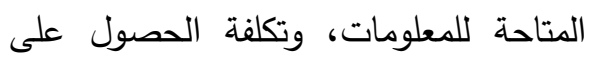
المعلومات والفوائد المرجوة منها، عدم وجود فروق في الوعي المعلوماتي تعود لـتغير

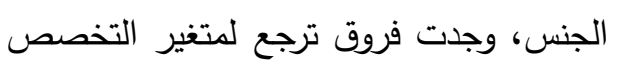
" معايير ACRLS : وهي معايير دولية حددتها جمعية

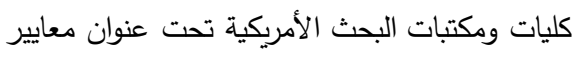

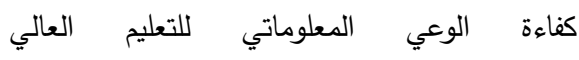
Association of College\& Research Libraries Standards

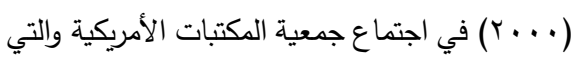

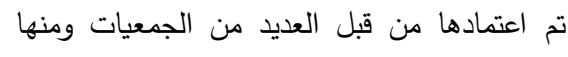

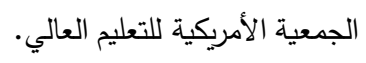




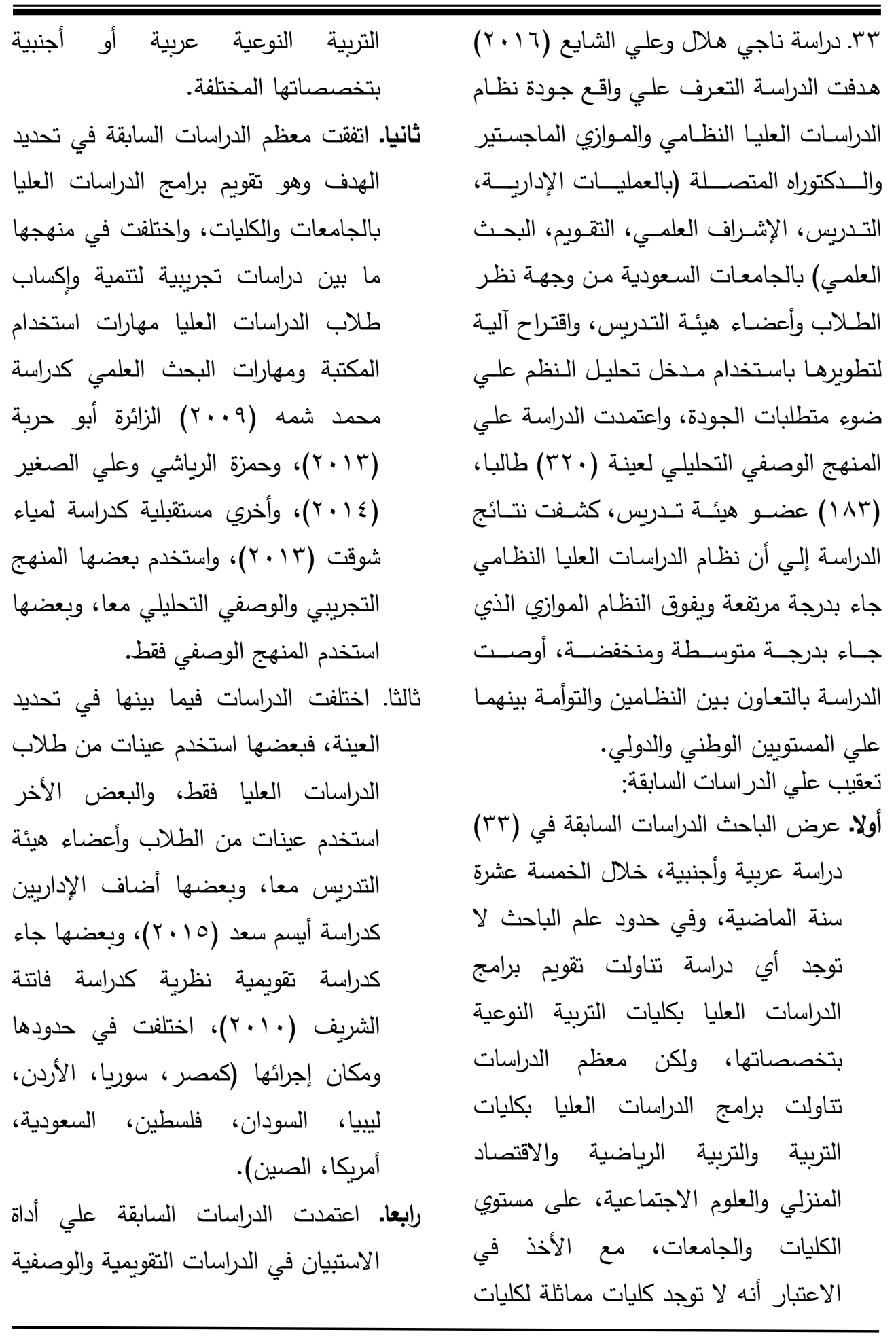




\begin{tabular}{|c|c|}
\hline 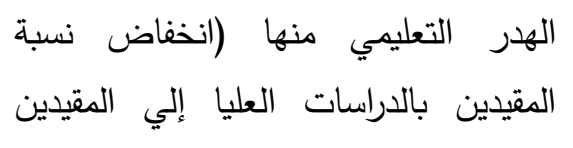 & التحليلية، والمقاييس في الدراسات \\
\hline بالمرحلة الجامعية، انخفاض إنتاجية & خامسا. كثفت نتائج بعض الدراسات دون \\
\hline الدراسات العليا في القدرة علي إنتاج المزيد & الأخرى عن وجود درجة من الرضا عن \\
\hline من حملة الماجستير والدكتوراه، ارتفاع & برامج الدراسات العليا وأن برامج الدراسات \\
\hline نسبة بقاء طالب الدراسات العليا في & العليا جيدة في بعض الجامعات كجامعة \\
\hline الحصول علي الدرجة العلمية، غياب & v أكتوبر · مصراته حاليا ـ بدولة ليبيا، \\
\hline العوامل التي تساعدعلي الإبداع & وبعض الجامعات السعودية والجامعة \\
\hline والابتكار ، انخفاض العائد المادي لأعضاء & الإسلامية بغزة وجامعة أكسفورد بالولايات \\
\hline هيئة التدريس نظير الإثراف علي الرسائل & المتحدة الأمريكية، وكثفت نتائج بعضها \\
\hline العلمية ومناقتشتها، ضعف ارتباط برامج & أن نظام الدراسات العليا في معظمه لا \\
\hline الدراسات العليا بمتطلبات سوق العمل، & يحقق أهدافه، وأن الأهداف تحتاج إلى \\
\hline ضعف المردود المعنوي من قبل & إعادة صياغة بطريقة تسهل قياسها إجرائيا \\
\hline المؤسسات المجمعية لطلاب الدراسات & ، فضلا عن وجود قصور في سياسة \\
\hline العليا، وزيادة الأعباء الأسرية والاجتماعية & القبول والتسجيل واللوائح الجامعية \\
\hline لهم، وضعف توفير الدعم المادي & والمقررات الدراسية ومحتواها واستراتيجيات \\
\hline للأبحاث التي يجريها الطلاب، وجود & التعليم والتعلم وأساليب التقويم والإرشاد \\
\hline تعجل في افتتاح الدراسات العليا مما أسهم & الأكاديمي والخدمات والتسهيلات البحثية، \\
\hline في انخفاض مستوي مدخلاتها & عدم وجود الخدمات والتسهيلات للأبحاث، \\
\hline ومخرجاتها، وجود قصور وضعف للدور & والساعات المعتمدة والإرشاد الأكاديمي، \\
\hline الذي تقوم به الكليات في تتمية المهارات & عدم استخدام الطرق الحديثة في التدريس، \\
\hline البحثية للطلاب، ووجود ضعف في تعليم & ضعف عدد البعثات الداخلية والخارجية \\
\hline مناهج البحث العلمي والتدريب عليه، & والمنح والإشراف المشترك، ضعف كفاية \\
\hline وعدم وجود قاعدة بيانات ومعلومات & الموارد المالية لتمويل سفر الأساتذة \\
\hline لطلاب الدراسات العليا، وجود معوقات & الزائرين والمؤتمرات العلمية، قلة عدد \\
\hline تواجه الطلاب والباحثين أثناء اختيار & المشاريع الدولية الممولة من خارج \\
\hline وتتفيذ موضوع البحث وبعد الانتهاء منه، & الجامعة، وجود جوانب متعددة لرظاهر \\
\hline
\end{tabular}


r. الرتبة العلمية: (أعضاء هيئة التدريس ،

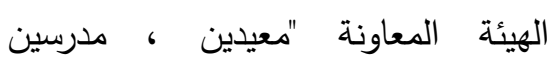
مساعدين"، طلاب دراسات عليا "الدبلوم الخاص، الماجستير ، الدكتوراه). r. التخصص:( صحافة ، إذاعة وتلفزيون،

\section{مسرح تربوي).}

ع. الكلية: التربية النوعية (المنصورة، الزقازيق، طنطا، بورسعيد، المنيا، أشمون، العباسية، (بنها). فروض الدراسة: ا. توجد فروق ذات دلالة إحصائية بين تكرارات اختيارات عينة الدراسة علي بدائل الاستجابات (موافق ،موافق إلي حد ما، غير موافق) في استبانه تقويم برامج الدراسات العليا بأقسام الإعلام التربوي. r. توجد فروق ذات دلالة إحصائية بين

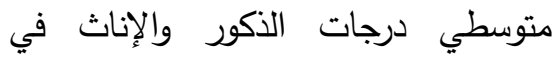
استبانه تقويم برامج الدراسات العليا بأقسام

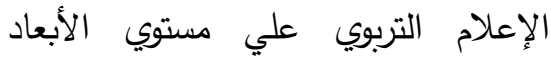
والدرجة الكلية للاستبانة. r. توجد فروق ذات دلالة إحصائية بين متوسطات درجات رتب أفراد العينة (أعضاء هيئة التدريس، الهيئة المعاونة، طلاب الدراسات العليا) في استبانه تقويم التهاء

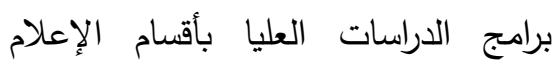
التربوي علي مستوي الأبعاد والدرجة

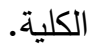

تأثر جودة أداء أعضاء هيئة تدريس الإعلام التربوي بالمشكلات التي تواجههم

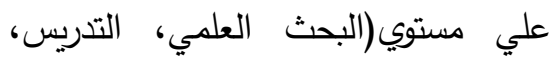
التدريب، خدمة المجتمع وتنمية البيئة، المهنة) بمعدل عال ومرتفع. سادسا. وجد تأثير لبعض المتغيرات دون

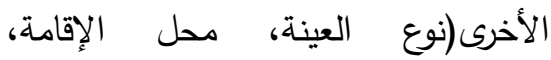

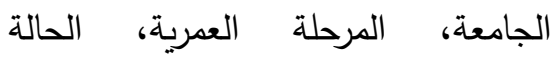
الاجتماعية، الوظيفة، سنوات الخبرة، التخصص، الفصل الدراسي) علي تقويم

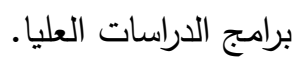

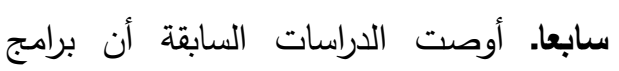
الدراسات العليا في حاجة إلى تقويم وتطوير مستمر يكفل لها الارتقاء ومواكبة كافة المستجدات والتطورات بما يحقق لهن لهن الجودة ومن ثم الاعتماد الأكاديمي، كما

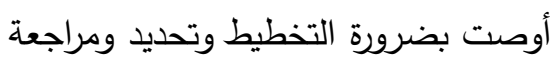
أهداف البرامج، والإجراءات الإدارية والمقررات وطرق واستراتيجيات التدريس وأساليب التقويم والبحث العلمي على نحور واتئرئي يجعلها قادرة على مواجهة المشكلات. ثامنا. استفاد الباحث من الدراسات السابقة في تحديد مشكلة الدراسة وصياغة تساؤلاتها وأهدافها وفروضها ومتغيراتها ومنهجها وعينتها وأداتها وتفسير نتائجها وصياغة ومناتها ومنها التصور المقترح والاهتداء للمراجع. متغير ات الدر اسة: 1. النوع : (ذكور ، إناث). 
اعتدل واستوي، وقد وردت عدة مشتقات للفعل )قوَّم (في القرآن؛ منها: لفظة أقوم؛ قال تعالى :

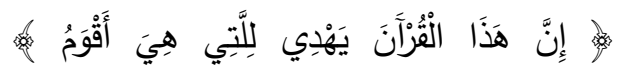
الإسراء (9).

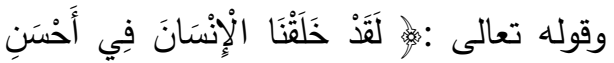

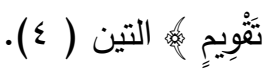

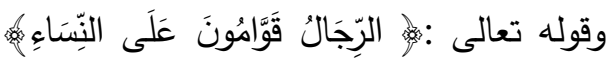
النساء: (๕؟)؛ أي: قائمون عليهن بالأمر

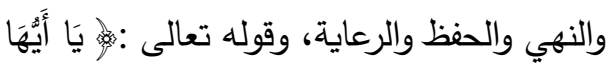

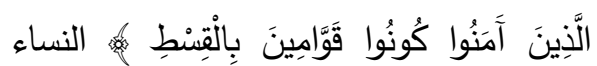
(1) (1)؛ أي كونوا مجتهدين في إقامة العدل والاستقامة. وقد أجاز مجمع اللغة العربية"التقييم "لبيان القيمـة وأورده في المعجم الوسبيط، وفيـه: قَيََّ

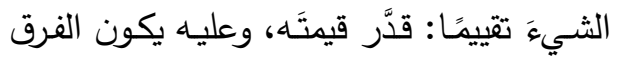

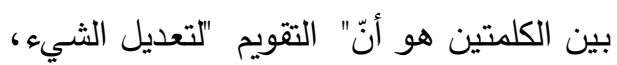

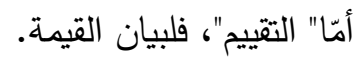

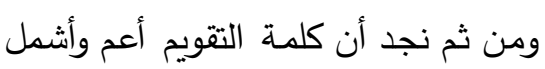
من كلمة التقييم، حيث لا يقف التقويم عند حد بيان قيمة شيء ما، بل لابد كذلك من محاولة

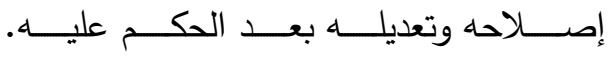

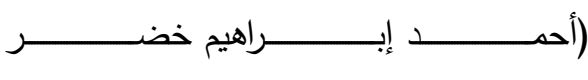

.(http://www.alukah.net،

وجاء تعريف التقويم في معجم المصطلحات التربوية علي أنه: إصدار حكم تجاه شيء ما أو موضوع ما، أما التقييم هو التهديه إعطاء قيمة للأشياء أو الموضوعات أو ماه
ع. توجد فروق ذات دلالة إحصائية بين

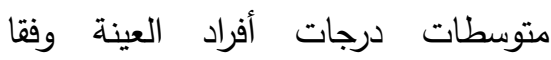
للتخصص (صحافة،إذاعة وتليفزيون، مسرح تربوي) في استبانه تقويم برامج الدراسات العليا بأقسام الإعلام التربوي توبي علي مستوي الأبعاد والدرجة الكلية لماستبانة.

$$
\text { الإطار المعرفي للار اسة: }
$$

يتاول الباحث الإطار المعرفي للدراسة للإنة

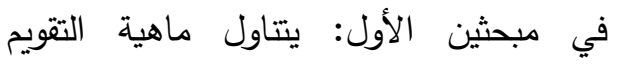
وأهميته وأنواعه، الثاني: الدراسات العليا بكلية التربية النوعية، وأهدافها، والبرامج التي تمنحها في مجال الإعلام التربوي. المبحث الأول: ماهية التقويم وأهميته وأنو اعه: أو لا التقويم في اللغة و الاصنية التخلاح:

جاء تعريف ومعنى كلمة تقويم في بعض

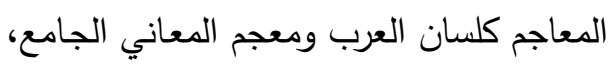

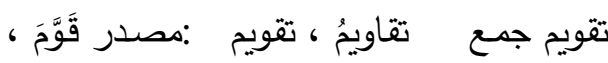

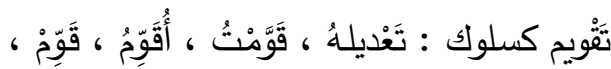

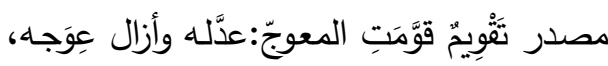

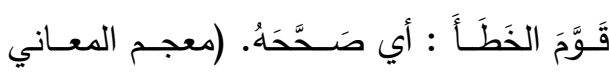
http://www.almaany.com) الجامع

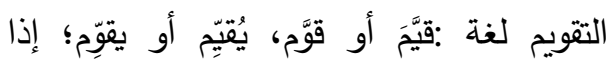

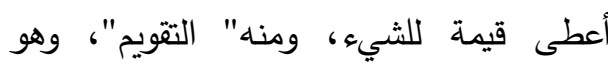

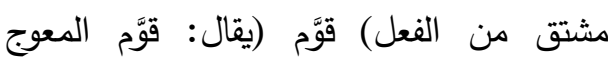

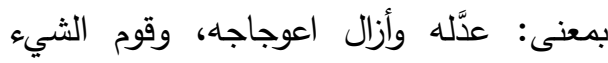
بمعنى قدره ووزنه وحكم على قيمته، واستقام 


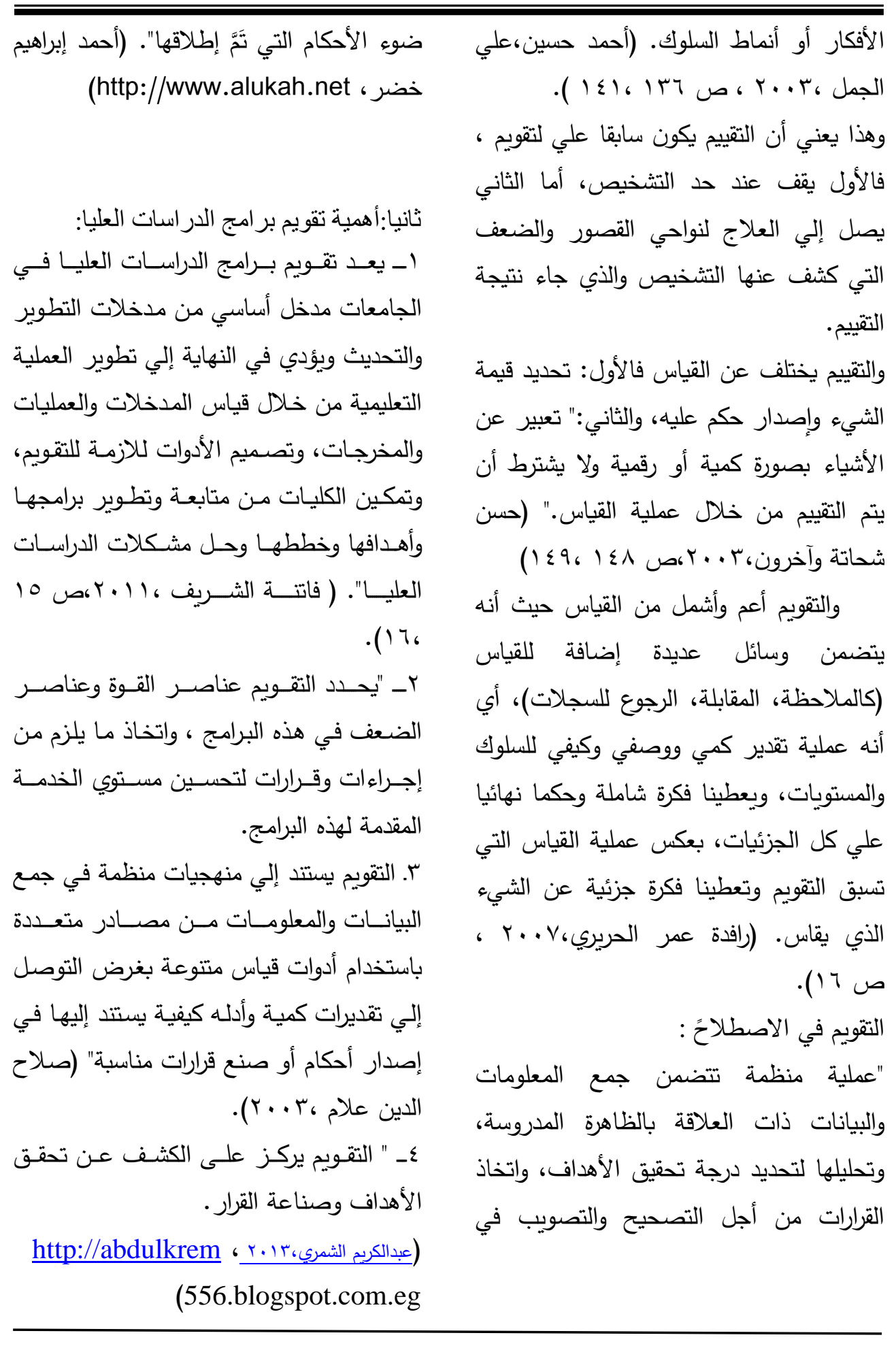


أ- تــويم تشخيصسي : يهـتم بتقـويم الوضـع

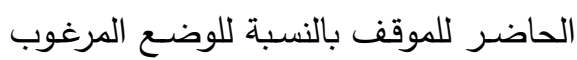

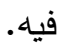

ب- تقويم تكويني : يركز على مدى سـرعة

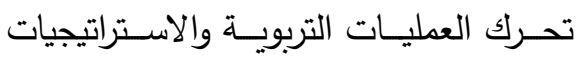

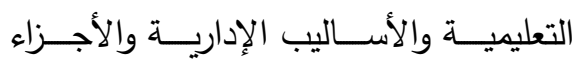

المختلفة من المنهج •

ج- تقويم نهائي : يصدر أحكاماً على الناتج

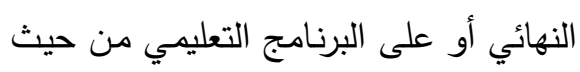

تحديد فاعلية البرنامج الإجمالي .

ع. التقويم حسب الجهة القائمة به :

أ- تقـويم رســي: أي تسـهم الجهـة الرســية

المسئولة عن البرنامج في الاثتراك بتقويمه

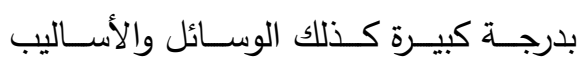

المستخدمة في التقويم تكون أساليب ووسائل

\section{علمية.}

ب- تقويم غير رسـي : يكون إسـهام الجهـة الرسمية المسئولة عن البرنامج في الاشتراك

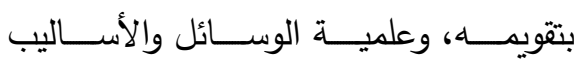
المستخدمة في التقويم أقل من النوع السابق.

هـ التقويم حسب المعلومات التي يعتمد عليها:

أ- تقويم كمي: يعتمد على النتائج الرقمية من بن

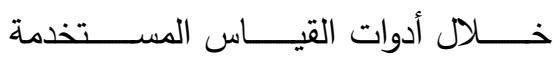

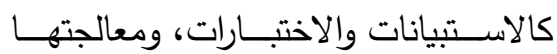

إحصائياً للحصول على استتاجات مبنية

$$
\text { على أسس علمية . }
$$

ثالثا : أنواع التقويم:

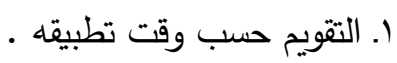

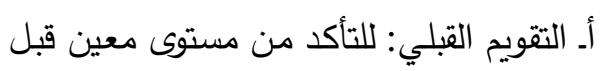

البدء بالعملية التعليمية.

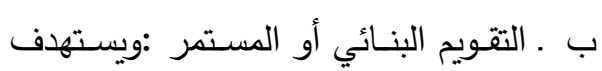

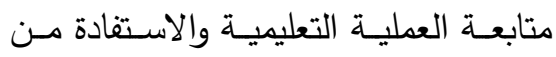

التغذية الراجعة بقصد التحسين أثنائها.

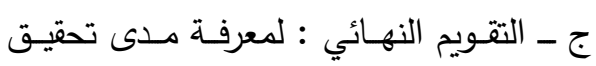

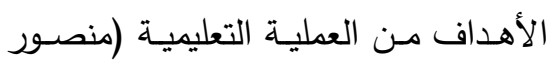

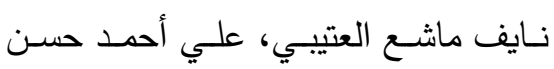

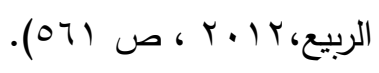

د- تقويم المتابعـة: وفيه يتم الاتصـال بجهات عمل الذين طبق عليهم البرنـامج لتحديد

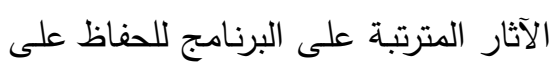

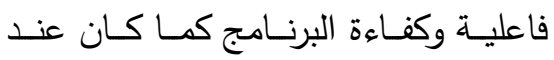

$$
\text { تجريبه. (عبد الكريم الثمري، ب ( • ץ) }
$$

r ا التقويم حسب تعددية القائمين به : أ- تقويم فردي : يقوم بـه فرد واحد ( كتقويم

الفـرد لغيـره، تقـويم الفـرد لنفسـه (التــويم

$$
\text { الذاتي). }
$$

ب- تقـويم جمـاعي: كتقـويم الجماعـة لنفسهـا

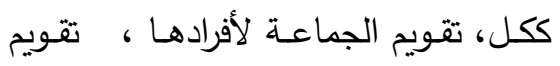
الجماعة لجماعة أخري. r. التقويم حسب الغرض من التقويم : 


$$
\begin{aligned}
& \text { (التثخيصي، جماعي، الكمي، الوصفي } \\
& \text { التحليلي المقارن). } \\
& \text { العالم العربي والأجنبي. }
\end{aligned}
$$

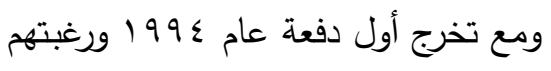

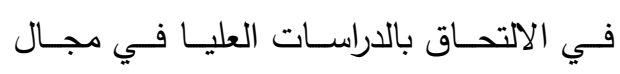

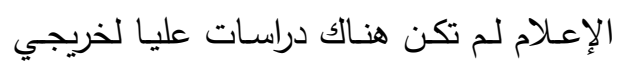
الإعلام التربوي بكليات التربية النوعيـة، وظل

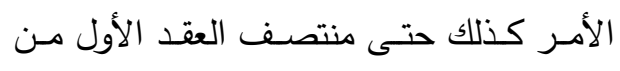

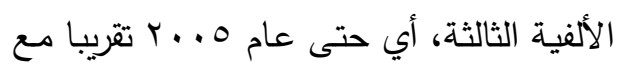
فتح باب الدراسات العليا ببعض أقسام الإعلام

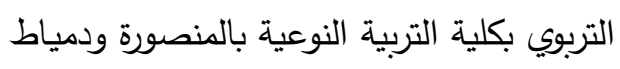

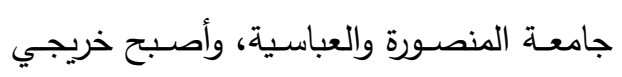
أقسـام الإعـلام التربوي الـراغبين في مواصـلة

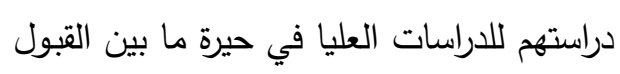

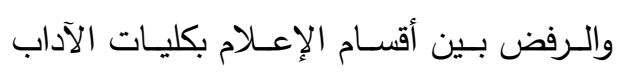

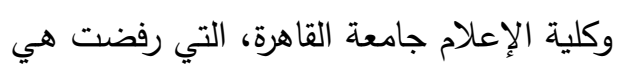

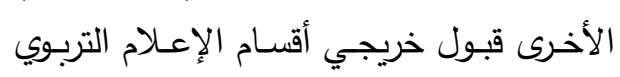

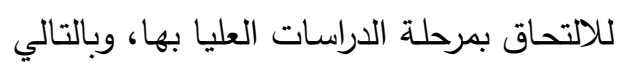

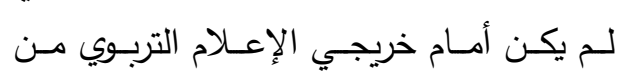
باحثين أو معيدين أو مدرسين مساعدين سوي الاعلام لتربـين
ب- تقويم نوعي : يعتمد على الآراء

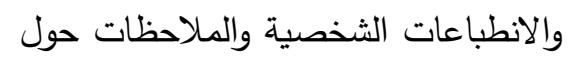

$$
\text { ד. التقويم حسب القائمين به : }
$$

أ- تقويم داخلي : القائمين بالتقويم من داخل البرنامج أو المشروع المراد تقويمه.

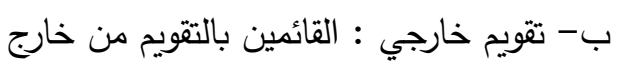
البرنامج المراد تقويمه.

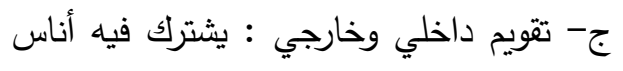
من داخل البرنامج وخارجه. V. التقويم حسب طبيعة معالجة البيانات : أ- تقويم وصفي : يعتمد على عرض البيانات

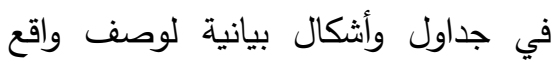

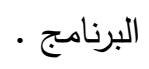
ب- تقويم مقارن : يتم فيه مقارنة النتائج التي أسفر عنها تقويم البرنامج بنتائج عمليات تقويم لبرامج مماثلة أو بنتائج عمليات لثنات عمليات تقويم تمت للبرنامج نفسه . تجويم

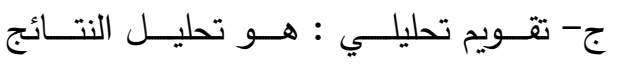

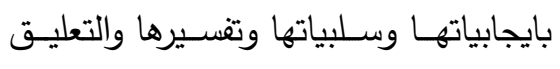

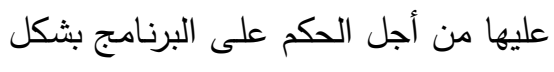

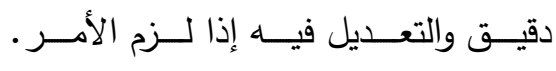

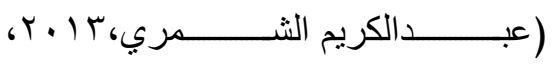
http://abdulkrem556.blogspot.c (om.eg والدراسة الحالية تكاد تجمع في معظمها بعض كالئل من أثكال التقويم السابقة كالتقويم 
وإذا نظرنـا لعـد أعضــاء هيئسة التـدريس

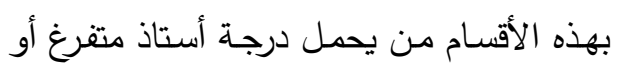

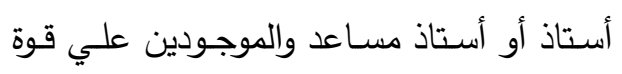
العمل، حتى وقت تطبيق الدراسة نجدهم (1)

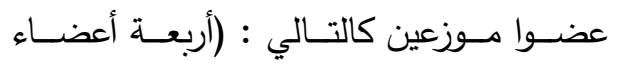
بالمنصـورة، ثلاثـة أعضــاء بالعباسـية، ثلاثـة

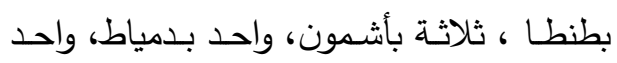

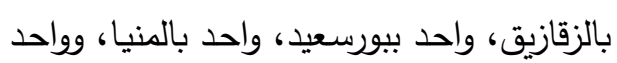

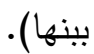
ثنانيـا: الأهداف الإسـتر اتيجية للار اسـات العليـا

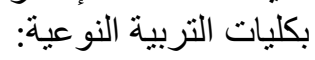
لقد حددت بعض لـوائح كليـات التربيـة

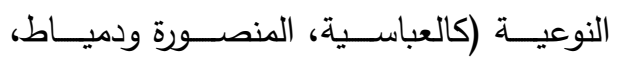
الزقازيق، المنيا، أشمون، قنا) أهداف الدراسات

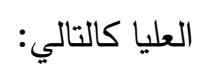
ا ـ تخريج معلم نوعي (أخصائي) متميز قادر علي المنافسة في سوق العمل.

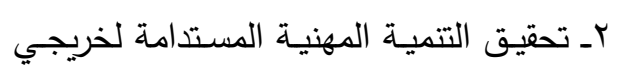
الكليـات مـن خـلال مواصــلة الدراسـات العليا. rــ إجـراء البحـوث والدراسـات المتميـزة فـي التخصصــات النوعيــة المختلفــة وتلبيــة احتياجـات المجتمـع مـن خـال الخدمات النوعية والمساهمة في حل مشكلاته.

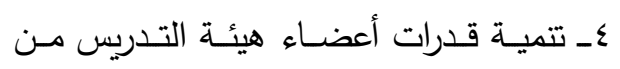
خـلال التأهيل العلمي والبحثي من خـلاد

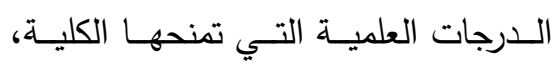
وتثجيع الباحثين علي التفاعل مع بعضهم تُنات
مكانين فقط يسمحان بقبـولهم، الأول : قسم

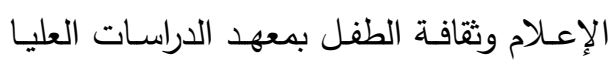
للطفولــة جامعـة عـين شــس، والـــي يمـنح درجتي الماجستير والـدكتوراه مسبوقة بسـنتين

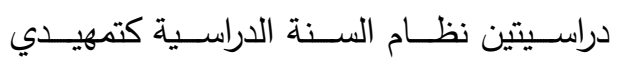

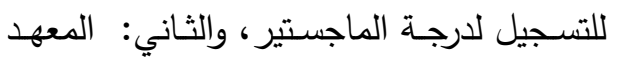

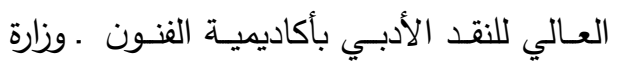

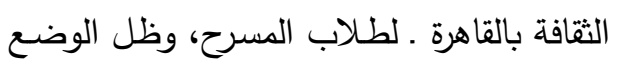

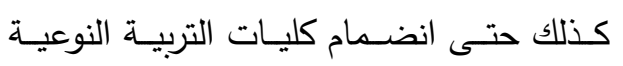
للجامعـات المصـرية كـل في محافظتــه عـام .1991 وعلـي الــرغم مــن انضــــام الكليــات للجامعات وإنهاء تبعيتها لوزارة التعليم العـالي إلا أنـه لم ينظر في فتح باب الدراسات العليا بأقسام الإعلام التربوي في بعض هذه لإنه الكليات

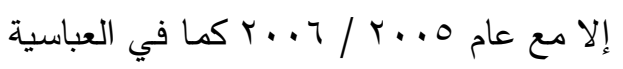

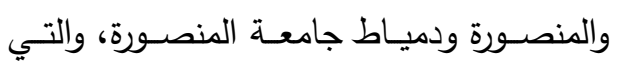
جاءت كملاذ مع معهد الدراسات العليا للطفولة ليلتحق بـه طـلاب الدراسـات العليـا والمعيدين والمدرسين المسـاعدين بكليات التربيـة النوعيـة

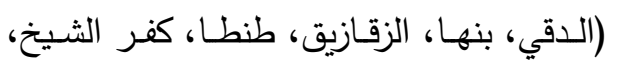

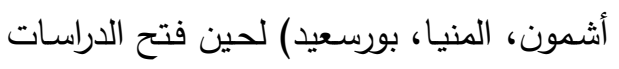

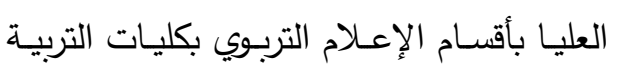

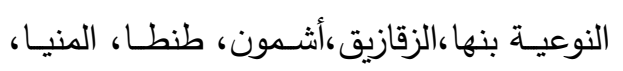
بورسـعيد) مـؤخرا دون النظـر إلـي الإمكانـات

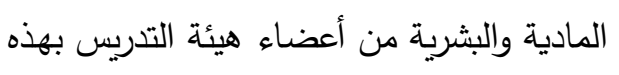

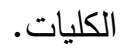




\begin{tabular}{|c|c|}
\hline 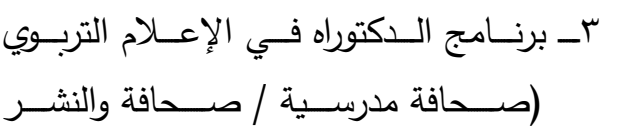 & 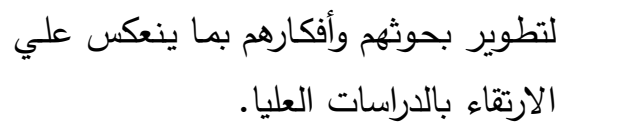 \\
\hline الالكترونـــي أو النشـــر الصـــحفي،إذاعة & ه. توفير برامج دراسية متميزة لمرحلة الدراسات \\
\hline وتليفزيون تعليمي/إذاعة وتليفزيون، المسرح & العليا تفي باحتياجات سوق العمل. \\
\hline التربوي/ فنون المسرح). & 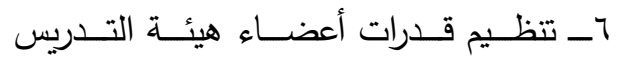 \\
\hline وهذه البرامج سيتم توضيحها وفقا لكل كلية في & ومعــاونيهم فـي مهــارات التـدريس ونظــم \\
\hline المبحث الأول بنتائج الدراسة التحليلية. & التعليم والتعلم. \\
\hline 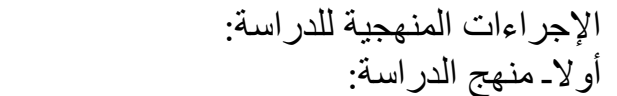 & Vـ التعـاون مـع الهيئـات والمؤسسـات العلميـة \\
\hline تعد الدراسة من الدراسات الوصفية التي تعتمد & والثقافيـة المصــرية والعربيــة والدوليــة فـي \\
\hline على المنهجين (الوصفي التحليلي، المقـارن) & معالجة القضايا التخصصية. \\
\hline باعتبارهمـا أنسب الدنـاهج للتحقق من أهداف & ^ــ المسـاهمة في تطوير التعليم في المجـالات \\
\hline ثانيا- عينة الدر اسة: & المتطلبات المعاصرة والمستقبلية. \\
\hline 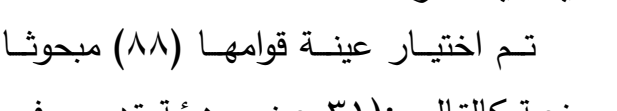 & ثالثا: البر امج التي تمنحـال الإعلام التربوي: كليـة التربيـة النوعيـة \\
\hline موزعـة كالتالي :(1) عضـو هيئة تدريس في & تمنح كليات التربية النوعية علي اختلاف \\
\hline تخصصــات (الصـــافة، الإذاعـة والتليفزيـون، & التخصصــات الـواردة بلوائحهـا البـرامج العلميـة \\
\hline المســرح التربــوي) القــائمين بالتــدريس فــي & التالية: \\
\hline الدراسات العليا بأقسام الإعلام التربوي بكليات & ا ـ الدبلوم الخاص في الإعـلام التربوي (عام، \\
\hline التربية النوعية، (Y0) من الهيئة المعاونـة في & صـحافة، إذاعـة وتليفزيـون تعليمي/ إذاعـة \\
\hline التخصصـات الـثلاث،(r؟r) طالبـا بالدراسـات & وتليفزيون، مسرح تربوي/ مسرح مدرسي/ \\
\hline العليــا الملتحقــين بـــرامج الــــبلوم الخــــــ & فنون المسرح، علاقات عامة وإعلان). \\
\hline والماجستير والدكتوراه (ع ب) ذكور ، (عه) إناث & r- برنــامج الماجسـتير في الإعـلام التربـوي \\
\hline - (ع §) تخصـص صــافة، (9 1) تخصـص & (صــــافة مدرســية / صــــافة ونشــر \\
\hline إذاعـة وتليفزيـون، (Y0) تخصـص مسـرح ) ، & الكترونــي أو النثــر الصـــفي ، إذاعــة \\
\hline المسحوبة منها ـ الجدول التـالي يوضـح توزيـع العينـة والكليـات & 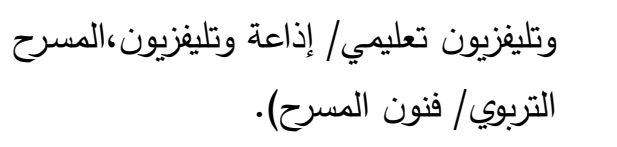 \\
\hline avive & جدول (1) عينة الدراسة (أعضا \\
\hline
\end{tabular}




\begin{tabular}{|c|c|c|c|c|c|c|c|c|c|}
\hline \multicolumn{6}{|c|}{ أعضاء هيئة التتريس ومعاونيهج + طلاب الدراسات العليا } & \multirow{3}{*}{ العدد } & \multirow{3}{*}{ 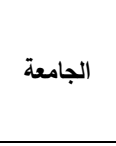 } & \multirow{3}{*}{ كلية التربية } & \multirow{3}{*}{ s } \\
\hline \multicolumn{2}{|c|}{ مسرح } & \multicolumn{2}{|c|}{ إذاعة } & \multicolumn{2}{|c|}{ ل صحافة } & & & & \\
\hline إناث & ذكور & إناث & ذكور & إناث & ذكور & & & & \\
\hline 1 & r & $\varepsilon$ & $r$ & $v$ & 1 & 11 & المنصورة & المنصورة & 1 \\
\hline- & - & $r$ & - & 1. & $\varepsilon$ & iv & بور سعيد & بور سعيد & r \\
\hline$\bullet$ & $\varepsilon$ & - & - & $\bullet$ & r & 14 & 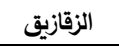 & 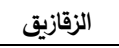 & $r$ \\
\hline 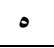 & 1 & - & - & 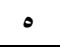 & 1 & ir & طنطا & طنطا & $\varepsilon$ \\
\hline$r$ & $r$ & 1 & 1 & 1 & $r$ & 1. & بنها & بنها & 0 \\
\hline- & - & $r$ & $r$ & - & $r$ & v & المنيا & المنيا & 1 \\
\hline 1 & - & $r$ & - & - & $r$ & 。 & المنوفية & أشمون & $v$ \\
\hline- & $r$ & - & - & - & 1 & $r$ & عين شمس & العباسية & $\wedge$ \\
\hline $1 \varepsilon$ & 11 & ir & $v$ & rA & 17 & $1 \wedge$ & & & \\
\hline \multicolumn{2}{|c|}{ ro } & \multicolumn{2}{|c|}{19} & \multicolumn{2}{|c|}{ ะ $\varepsilon$} & & \multicolumn{3}{|c|}{ المجموع الكلي } \\
\hline
\end{tabular}

0ـ كليـات التربيـة النوعيـة التـي بهـا أقسـام

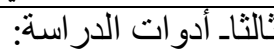

للإعـلام التربـوي وتراعـي التخصـص منــ

$$
\text { مرحلة البكالوريوس. }
$$

ج. كليات التربية النوعية التي بها دراسات عليا

$$
\text { في الإعلام التربوي }
$$

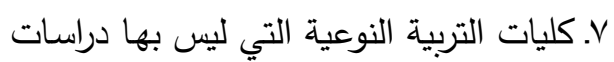
عليا بأقسام للإعلام التربوي .

^ــ وجود برنـامج للإعـلام التربوي ووجود رؤيـة ورسالة وأهداف لبرنامج الإعلام التربوي. 9. نظام القيد والقبول والتسجيل ببرامج الإعلام

$$
\text { التربوي. }
$$

• اــ البـرامج التـي تمنحهـا الكليـة : (الـدبلوم

، المهني، الدبلوم الخـاص، الماجستير

$$
\text { الاكتوراه). }
$$

11 ــــام الدراسـة ببـرامج الإعـلام التربـوي (فصل دراسي / العام الكامل، الساعات

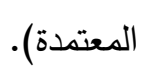
أ. أداة تحليل برامج الإعلام التربوي بالدراسات الت الترات

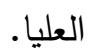
ب ـ استبانة تقويم برامج الدراسات العليا بأقسام الإعلام التربوي وجهة نظر أعضاء هيئة التدري ومعاونيهم وطلاب الإراسات

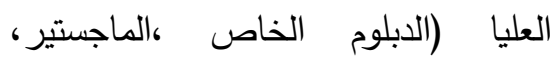
الدكتوراه).

أ. أداة تحليل برامج الإعلام التربوي بالدراسـات العليا.

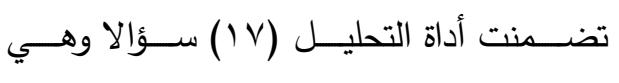
كالتالي: I. عدد كليات التربية النوعية في مصر •

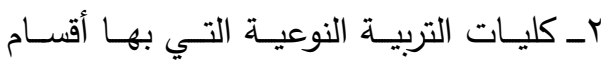

$$
\text { للإعلام التربوي. }
$$

rـ كليات التربية النوعية التي ليس بها أقسام للإعلام التربوي. عـ كليـات التربيـة النوعيـة التـي بهـا أقســام

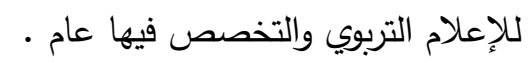




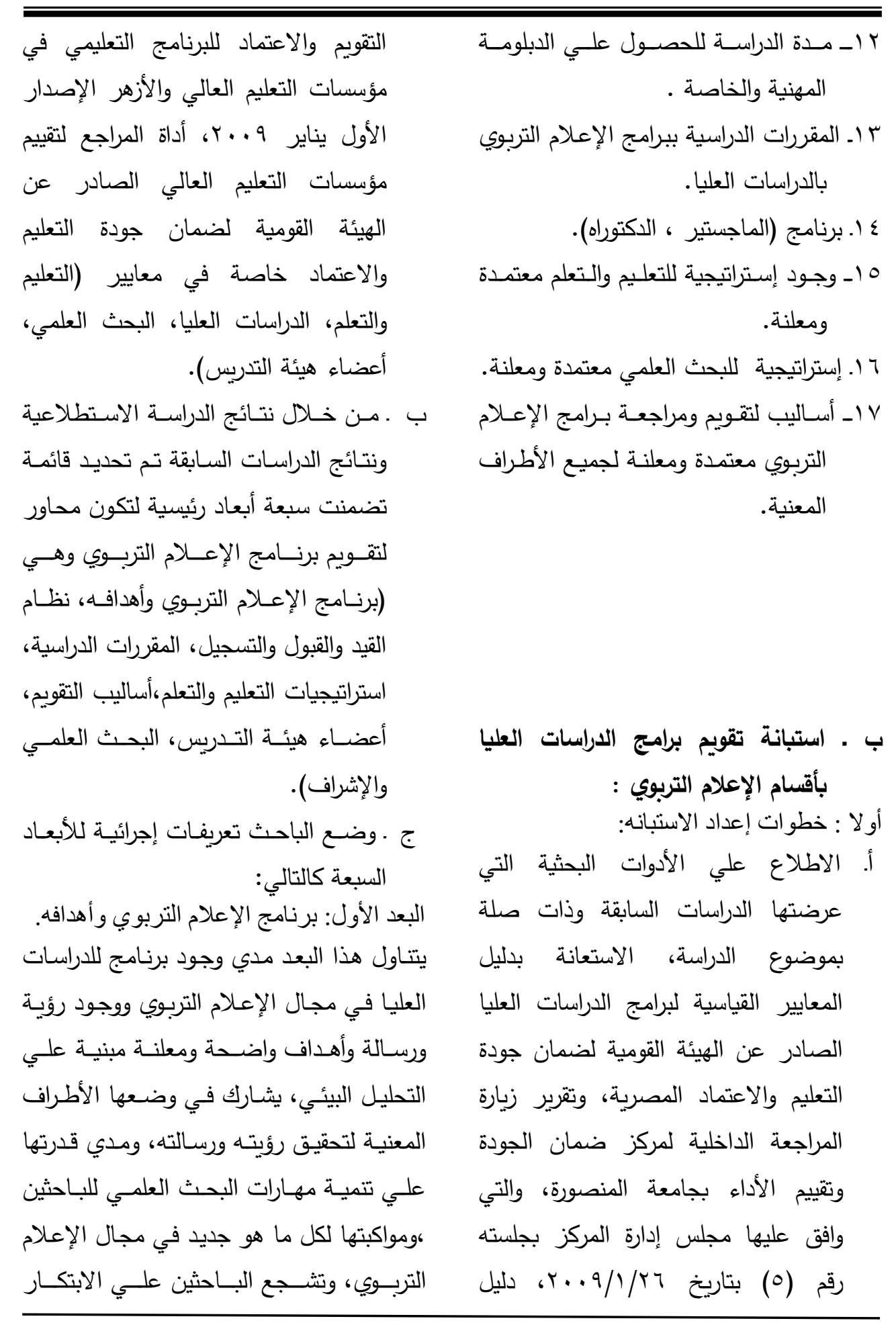




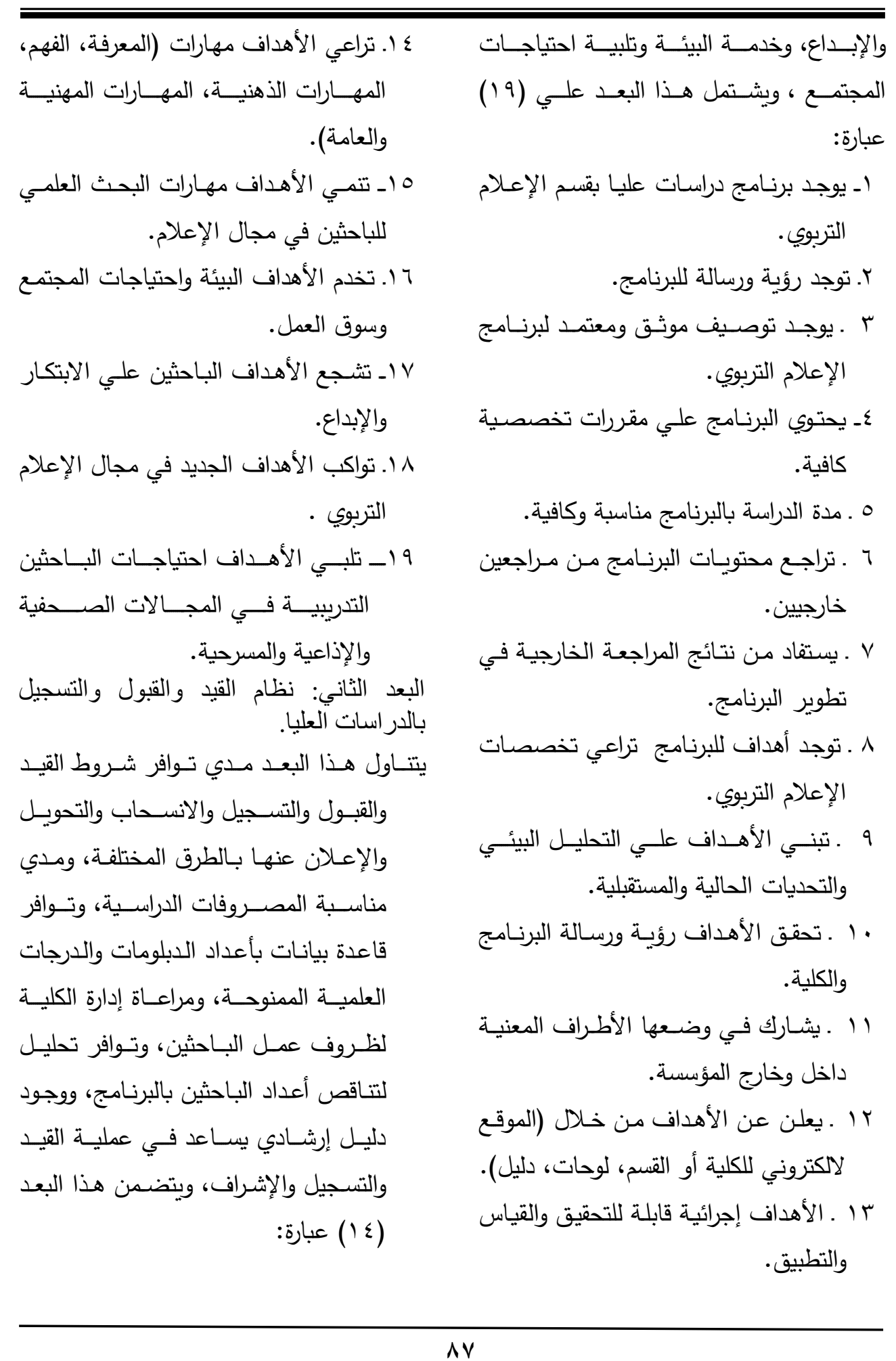




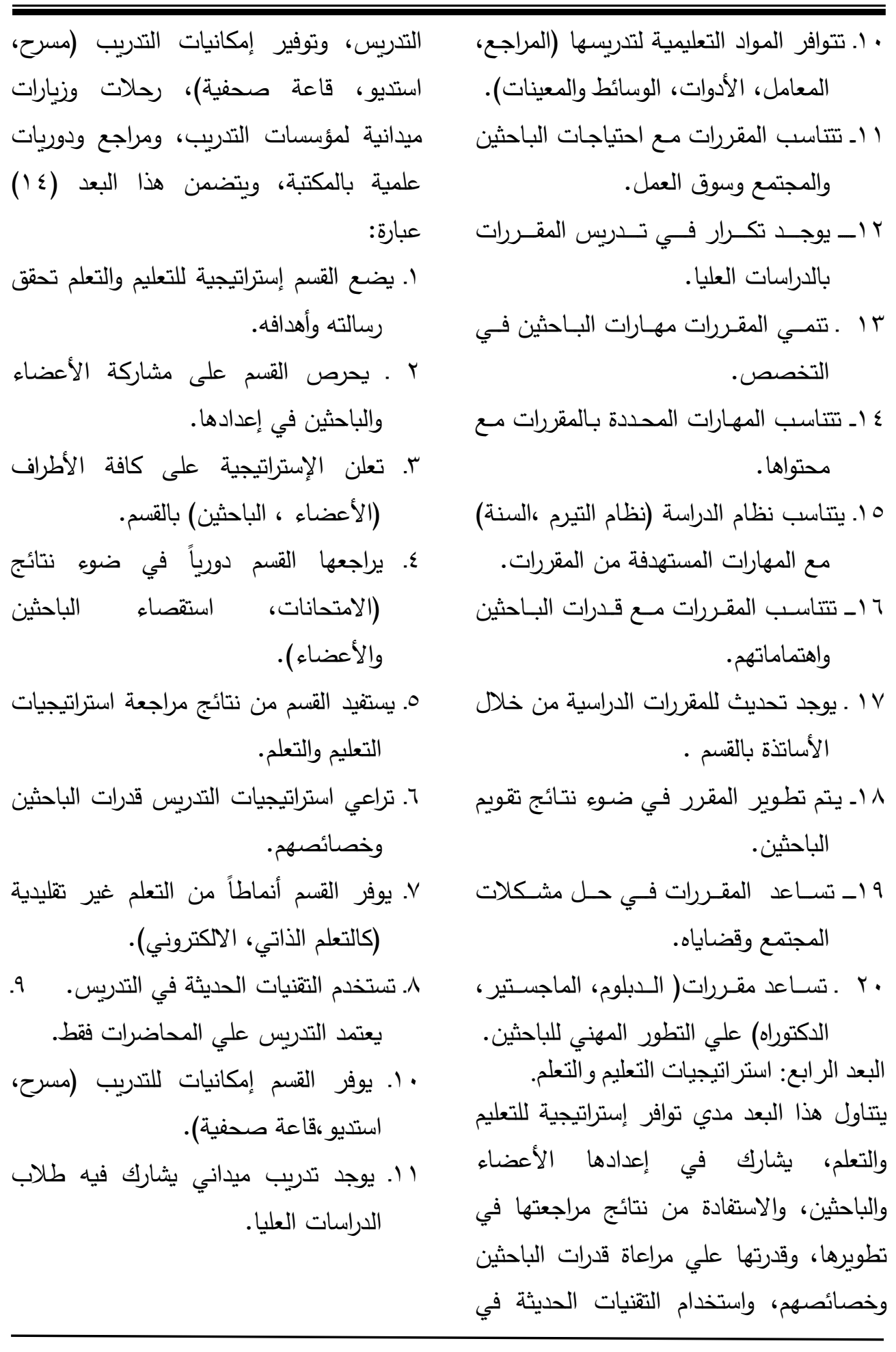


rا. يوفر القسم رحلات تعليمية وزيارات 9. تركز الاختبارات علي المهارات المعرفية والمهارية والسلوكية. ميدانية لمؤسسات التدريب.

• إختبارات القبول (التحريرية والثفوية) ذاتهات معايير محددة.

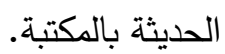

11. يتم تقييم أداء الباحثين قبل وأثثاء التسجيل ع ا. يحرص القسم على أن يتم التدريس من للارجات العلمية: (سمينارات، التقارير خلال متخصصين.

$$
\text { الدورية). }
$$

البعد الخامس: أساليب التقويم.

r ا. يحرص القسم على قياس رضا الباحثين عن برنامج الإعلام التربوي.

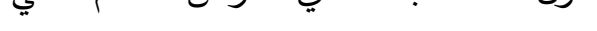
التقويم المستمر لبرامج الإعلام التربوي، ووضع هدي البعد السادس: أعضاء هيئة التدريس. آليات تضمن العدالة في تقويم الطلاب وإعلام يتتاول هذا البعد مدي التزام أعضاء هيئة التئة الباحثين بها، واستخدام نظام المدتحن الخارجي بالتدريس بالمحاضرات ومشاركتهم في الخطة والاستفادة من نتائج التقويم في تحسين وتطوير البحثية وأنثطة خدمة المجتمع والبيئة وضمان لئن البرنامج ومقرراته، وأساليب التقويم المتبعة الجودة، وتتمية موارد الكلية، واستخدام التقنيات الحديثة في التدريس، والتواصل مع الطلاب ،وقياس رضا الباحثين والإفادة منه في تطوير البرنامج، ويتضمن هذا البعد (r) (I عبارة: والزملاء، وتثجيع الباحثين علي الابتكار والتعليم والبحث العلمي، ويتضمن هذا البعد

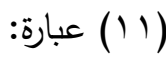

1. يلتزم بالجداول الدراسية ووقت المحاضرة.

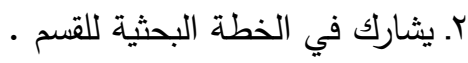
ا. يحرص القسم علي التقويم المستمر لبرنامج الإعلام التربوي.

r- يـوفر القسم آليـة للتأكد مـن عدالـة تقويم الإعليم الباحثين. r. يتم إعلام الباحثين بنتائج التقويم. rـ يسـاهم في أنشـطة خدمـة المجتمع وتتميـة

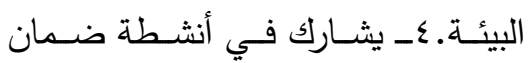
ع. يستخدم القسم نظام المدتحنين الخارجيين. ه. يتم تحليل نتائج تقويم الباحثين. الجودة والتطوير بالقسم.

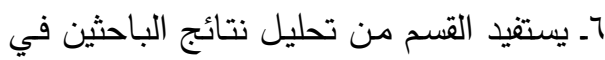

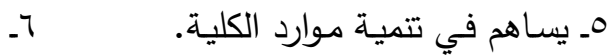
تطوير البرنامج ومقرراته. يحرص علي طيب العلاقة مع الرؤساء Vـ يناقش القسم تقارير نتائج الامتحانـات من لن والزملاء والباحثين.

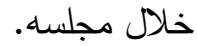
V. يتوافق ما يقوم بتدريسه بالمحاضرات مع مالياكين.

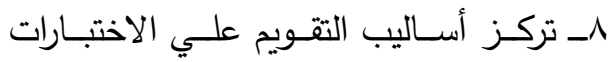

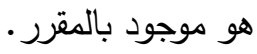
(الثفوية ،التحريرية، النهائية). 


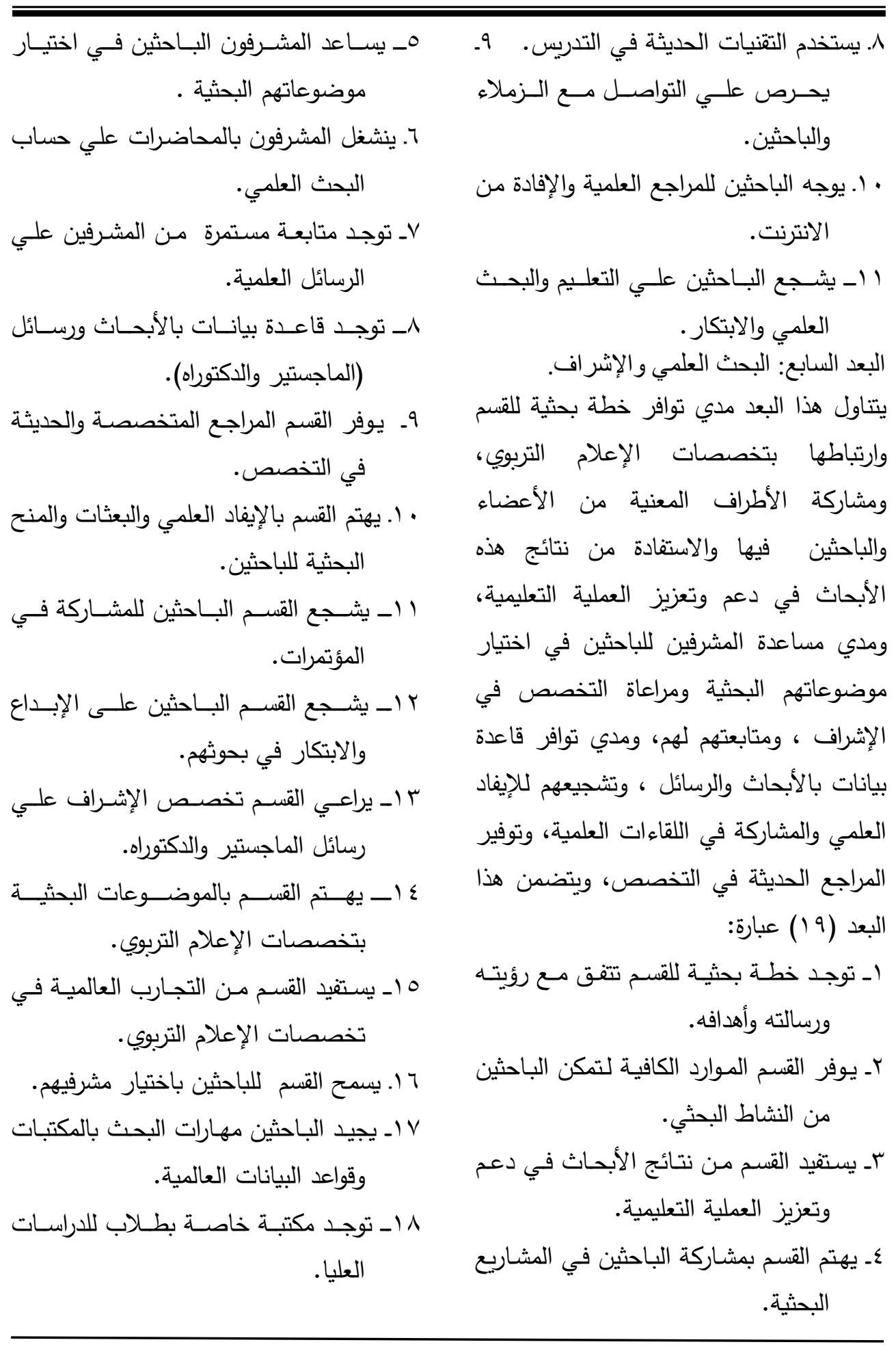


يقوم طلابه، كما أن الدراسات السابقة العربية منها والأجنبية كدراسة كل من ان لانهات

، (TRICE , VERHEY, 2002)

اهتمت بتقويم أعضاء هيئة التدريس.

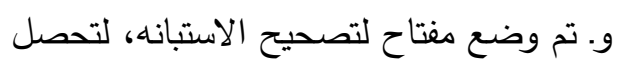

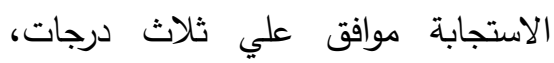

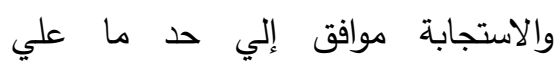

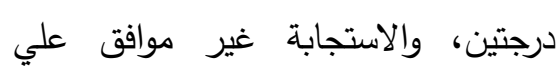
د) درجة واحدة، مع مراعاة العبارتين

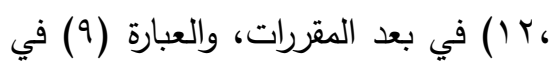
بعد استراتجيات التعليم والتعلم، والعبارة (†) في بعد البحث العلمي كعبارات سلبية

$$
\text { فتكون الدرجة العكس. }
$$

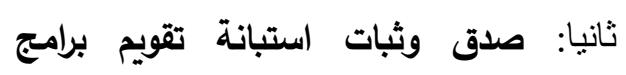
الدراسات العليا بأقسام الإعلام التربوي.

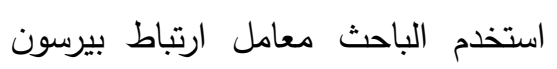

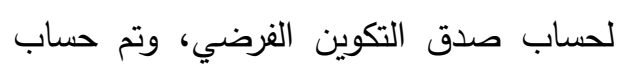

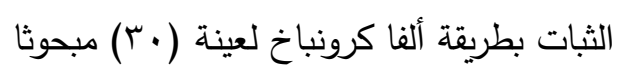
من أعضاء هيئة التدريس والهيئة المعاونة وطلاب الدبلوم الخاص والماجستير والدكتوراه، بواقع (•) (1) أفراد من كل فئة، ويمكن تتاول

$$
\text { النتائج في جدول (r) التالي: الترد }
$$

9 اـ تقدم المكتبة خدمات وتسهيلات للباحثين

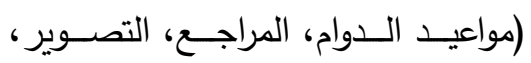
الاستعارة، الاستفادة من قواعد البيانات). ـ ومن ثم صار عدد عبارات المقياس (9. ( ) عبارة، وتم تحديد ثلاثة بدائل (موافق، موافق إلي حد ما، غير موافق) لكل عبارة، ويختار المبحوث منها اختيارا واحدا يعبر عن رأيه.

هـ . عرض الباحث الاستبانه علي (· (1)

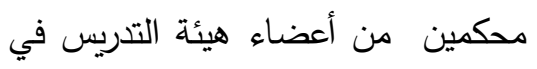
مجال الإعلام والإعلام التربوي والعلوم هنئ التربوية، وجاءت ردودهم نحو تعديل

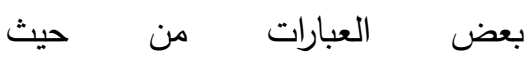
الصياغة،وحذف البعد السادس عضو هيئة التدريس،ولكن رأي الباحث ضرورة الإبقاء علي هذا البعد خاصة أن عضو هيئة التدريس هو عنصر أساسي من هن عناصر العملية التعليمية ويشارك في هئر الخطة البحثية للقسم وأنشطة ضمان الجودة والتطوير وخدمة المجتمع وتتمية

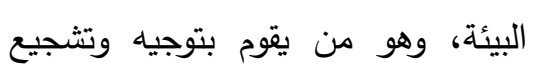

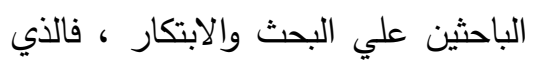

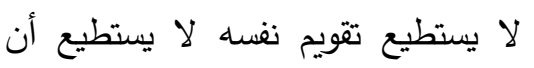

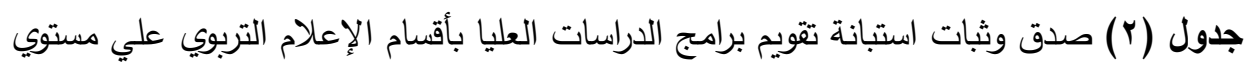

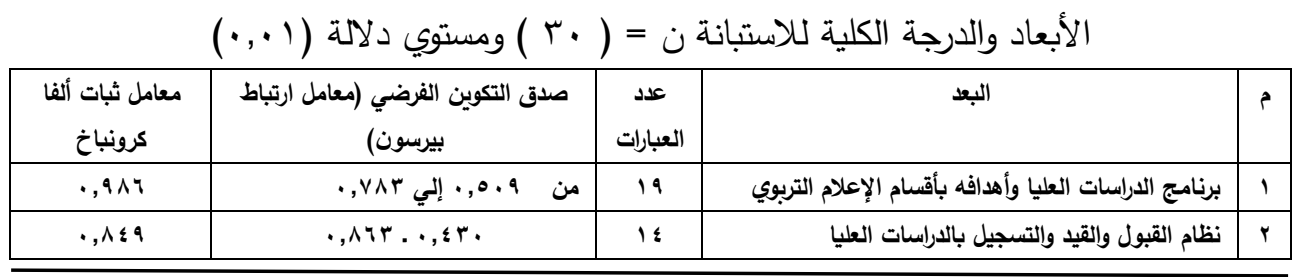




\begin{tabular}{|c|c|c|c|c|}
\hline., $9 \wedge 9$ & 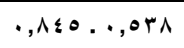 & r. & المقررات الدراسية & $r$ \\
\hline$\cdot, \wedge 01$ & $\cdot, V Y \leqslant \ldots, \varepsilon Y$. & $1 \varepsilon$ & استراتيجيات التعليم والتعلم: & $\varepsilon$ \\
\hline$\cdot, \Lambda$. A & $\cdot, \vee \vee \wedge १ \ldots, \varepsilon \cdot \checkmark$ & ir & أساليب التقويم & 0 \\
\hline$\cdot$, Aiv & ציז, . • • • & 11 & أعضاء هيئة التدريس & 1 \\
\hline$\cdot, 9 \wedge \varepsilon$ & ש & 19 & البحث العلمي والإثراف & v \\
\hline$\cdot, 941$ & סצז, • ז ., & 1.9 & الارجة الكلية للاستبانة & \\
\hline
\end{tabular}

من نتائج الجدول السابق يتضح أن ا. كليات التربية النوعية بتخصصاتها المختلفة

ليس لها كليات مناظرة علي مستوي العالم

الاستبانه وأبعادها السبعة ذات معاملات

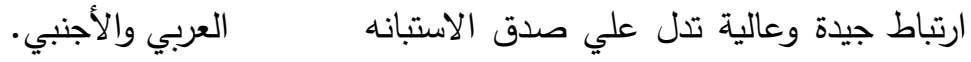

علي مستوي الأبعاد والدرجة الكلية للاستبانة، ب الت عدد كليات التربية النوعية في جمهورية مصر العربية (17) كلية تمثل (17) (1) (1)

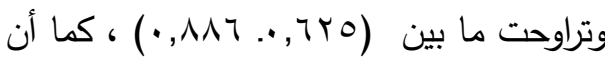
جامعة حكومية تقع في (10) محافظة، الاستبانه ذات معامل ثبات جيذ وعالي علي هي كلية التربية النوعية (الدقي جامعة مستوي الأبعاد والدرجة الكلية وبلغ (r9,·) عند مستوي دلالة (1 ., •) • القاهرة، العباسية جامعة عين شمس، الإسكندرية جامعة الإسكندرية، أسيوط جامعة أسيوط، الزقازيق جامعة الزقازيق، المنصورة وفرعيها بميت غمر ومنية

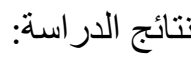
النصر جامعة المنصورة، بور سعيد جامعة بورسعيد، طنطا جامعة طنطا، أشمون جامعة المنوفية، المنيا جامعة المنيا، قنا جامعة الوادي الجديد، الفيوم جامعة الفيوم، دمياط جامعة دمياط، بنها جامعة بنها، كفر الثيخ جامعة كفر الشيخ، أسوان جامعة أسوان . كلية مستحدثة). r. عدد كليات التربية النوعية التي بها تخصص الإعلام التربوي في مرحلة البكالوريوس (Y) (Y) كلية هي كلية التربية النوعية (الدقي ، العباسية الزقازيق،

يتم تتاول نتائج الدراسة في مبحثين الأول: تحليل برامج الدراسات العليا بأقسام الإعلام التربوي(الدبلوم، الماجستير، الدكتوراه) الثاني: التحقق من فروض الدراسة الميدانية. المبحث الأول: تحليل برامج الدراستات العليا بأقسام الإعلام التربوي. من خلال اطلاع الباحث علي لوائح الدراسات العليا لكليات التربية النوعية ودليل الدراسات العليا والموقع الاككتروني لكل كلية علي شبكة الانترنت ومقابلة أفراد عينة الدراسة، توصل الباحث إلي النتائج التالية: . 


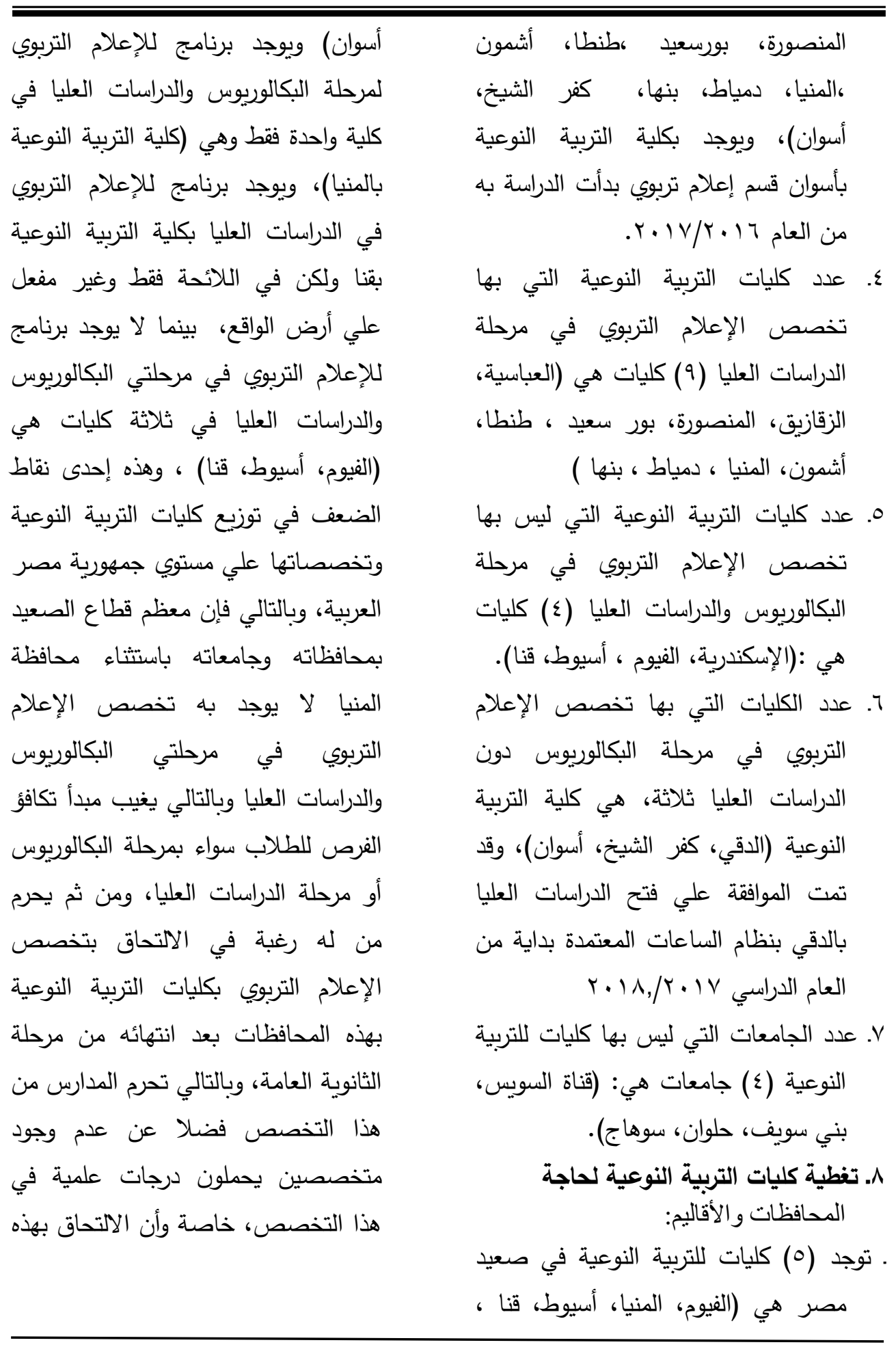




\begin{tabular}{|c|c|}
\hline 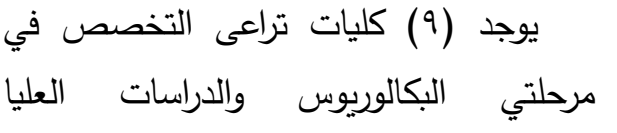 & والإقليمي. \\
\hline (العباسية، الزقازيق ، المنصورة ، بورسعيد & توجد كليتان تغطي حاجة محافظتي القاهرة \\
\hline ،طنطا ،أشمون ،دمياط ، بنها ،المنيا ) مع & والجيزة،هما كليتا التربية النوعية (الدقي، \\
\hline الأخذ في الاعتبار أن الدراسة في برنامج & العباسية) ويوجد بالأولي قسم إعلام تربوي \\
\hline الدبلوم الخاص في كليات (العباسية، & لمرحلة البكالوريوس دون الدراسات العليا \\
\hline المنصورة، أثمون، دمياط ،المنيا) عام ، & ويلتحق خيج القسم والهيئة المعاونة \\
\hline ويتخصص الطالب وفقا لموضوع الرسالة في & بالدراسات العليا بأي كلية للتربية النوعية \\
\hline الماجستير والدكتوراه. & بها تخصص الإعلام التربوي أو معهد \\
\hline • يوجد (ع) كليات تراعي التخصص الدقيق في & الدراسات العليا للطفولة جامعة عين \\
\hline برنامج (الدبلوم) والماجستير والدكتوراه، في & شمس، وأما كلية التربية النوعية \\
\hline تخصصــات الإعـلام التزبـوي (الصـحافة، & بالعباسية يوجد بها قسم إعلام تربوي \\
\hline الإذاعـة والتليفزيـون ،المسـرح التربـوي أو & لمرحلتي البكالوريوس والدراسات العليا). \\
\hline المدرسي)،هي (الزقازيق، بورسعيد، طنطا، & • توجد (^) كليات تغطي حاجة محافظات \\
\hline بنهـا)، وتزيــــ طنطــا علـي هـذه البـرامج & الوجه البحري والدلتا (الإسكندرية، \\
\hline برنامج العلاقات العامة والإعلان. & الزقازيق، المنصورة، طنطا، أشون، \\
\hline ـ ووفقـا لتوجيهـات لجنـة قطـاع كليـات التربيـة & دمياط ، بنها، كفر الثيخ) وليس \\
\hline النوعيـة والاقتصــاد المنزلــي يـتـم إلغـــاء & بالإسكندرية تخصص الإعلام التزبوي \\
\hline التخصصــات الدقيقـة في أقســام الإعـلام & بمرحلة البكالوريوس والدراسات العليا. \\
\hline التربوي في مرحلة البكالوريوس عند إعداد & • توجد كلية واحدة فقط هي كلية التربية النوعية \\
\hline اللــوائح الجديــدة لمرحلـــة البكــالوريوس، & بورسعيد تغطي حاجة محافظة بورسعيد \\
\hline ومراعاة التخصص في الدراسات العليا. & دون ددن قناة(السويس،الإسماعيلية) \\
\hline يوجد (r) كليات تأخذ بنظام الساعات & ويوجد بها تخصص الإعلام التزبوي في \\
\hline المعتمدة في برنامج الدراسات العليا في & مرحلة البكالوريوس والدراسات العليا وهذا \\
\hline تخصص الإعلام التربوي هي كليات & غير كاف لسد حاجة الثلاث محافظات \\
\hline التربية النوعية (الزقازيق، بنها، بورسعيد) & لهذا التخصص. \\
\hline بينما توجد (؟) كليات تكون الدراسة فيها & 9. توافر تخصص الإعلام التربوي بالكليات: \\
\hline
\end{tabular}




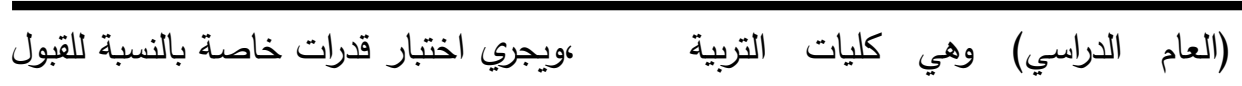
النوعية (العباسية، المنصورة ، دمياط، في الدبلوم الخاص.

ـ يمنح القسم درجة الدبلوم الخاص في التربية

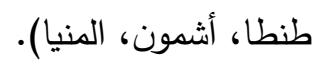
النوعية الإعلام التربوي عام (صحافة وإذاعة •

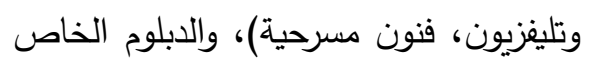

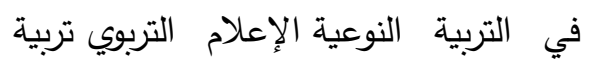
خاصة، وهذه إحدى نقاط القوة التي يتميز

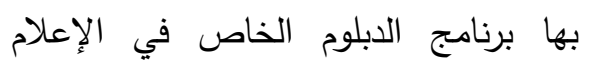
تربوي لذوي الاحتياجات الخاصة، وهذا غير متاح بأقسام الإعلام التربوي بكليات التربية النوعية المناظرة. ـ مدة الدراسة ببرنامج الدبلوم الخاص سنتان دراسيتان، يعقد امتحان الدور الأول في بلدي شهر يونيو والثاني في نوفمبر فيما رسب ديب الون فيه الطالب أو تغيب عنه ، وإذيو رسوبه أو تغيب جاز لله أن يعيد قيده فيعيد

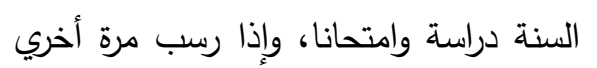
ألغي قيده نهائيا. ـ المقررات الاراسية للدبلوم الخاص: مقررات السنة الدراسية الأولي والثانية ويمكن تتاولها في الجدولين (ب ، ع ) التاليين: التي بها دراسات عليا في الإعلام التربوي: أو لا: كلية التربية النوعية بالعباسية جامعة عين الاعلامين ـ مسمي القسم بمرحلة البكالوريوس والدراسات

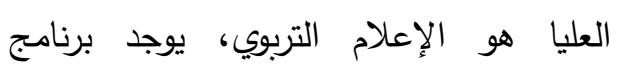

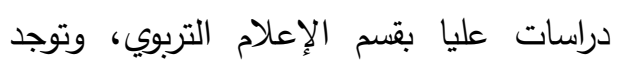
رؤية ورسالة وأهداف إستراتيجية للكلية، بينما لإعلام لا توجد رؤية ورسالة وأهداف لبرنامج الدراسات العليا بقسم الإعلام التربوي، متاحة علي الموقع الالكتروني للكلية، تتبني الكلية رؤية ورسالة وأهداف قطاع الدراسات العليا بالجامعة، توجد لائحة للدراسات العليا بنظام الساعات الدراسية.

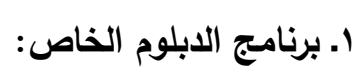

. يشترط قيد الطالب في الدبلوم أن يكون حاصلا علي درجة البكالوريوس في التربية النوعية من احدي الجامعات المصرية أو البكالورئ علي درجة معادلة لها من معهد علمي معترف به بشرط الحصول علي تقدير جيد جدول (r) الساعات التدريسية لبرنامج الدبلوم الخاص في الإعلام التربوي صحافة وإذاعة وتليفزيون

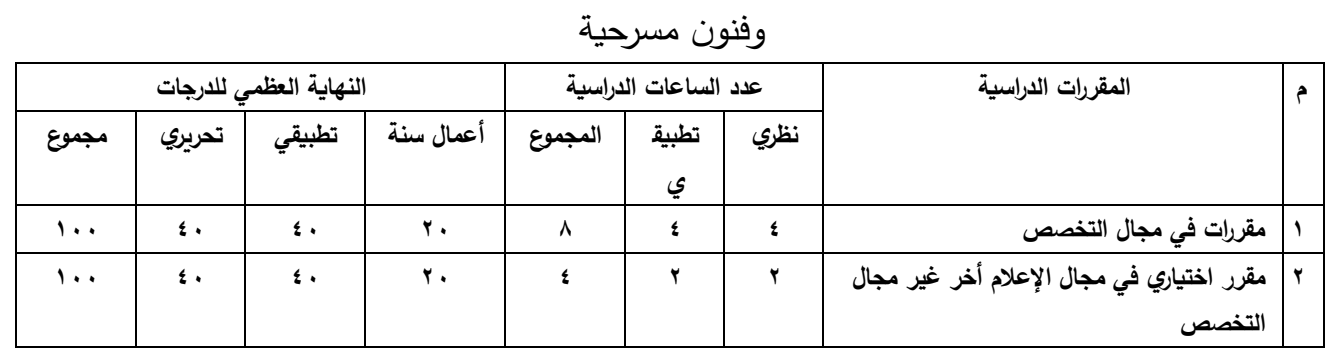




\begin{tabular}{|c|c|c|c|c|c|c|c|c|}
\hline ๑. & $\varepsilon$. & - & 1. & r & - & $r$ & طرق البحث الإحصاء & $r$ \\
\hline$\circ$. & $\varepsilon$. & - & 1. & $r$ & - & $r$ & أصول التربية & $\varepsilon$ \\
\hline ๑. & $\varepsilon$. & - & 1. & r & - & $r$ & دراسات في الإعلام التربوي بلغة أجنبية & - \\
\hline o. & - & $\varepsilon$. & 1. & $r$ & r & - & حلقة مناقشة & 7 \\
\hline$\varepsilon \ldots$ & & & & $r$. & $\wedge$ & Ir & المجموع & \\
\hline
\end{tabular}

جدول (؛ ) الساعات التدريسية لبرنامج الدبلوم الخاص في الإعلام التربوي صحافة وإذاعة وتليفزيون

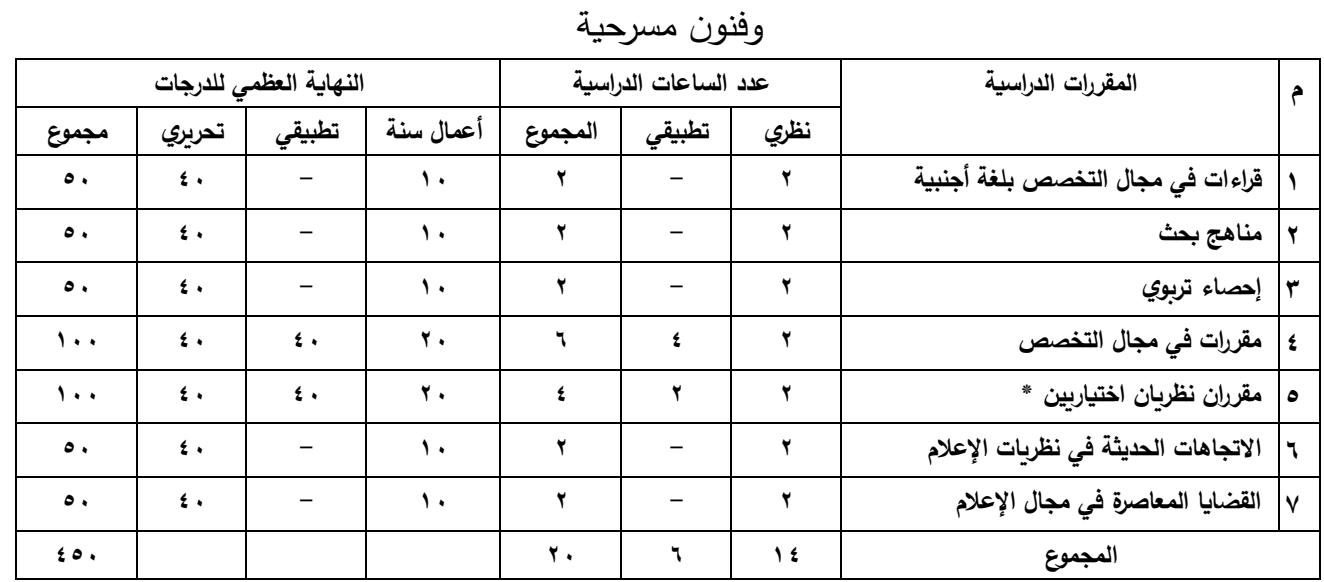

(•) ساعة منها (^) ساعات مقررات

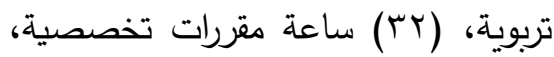
وبذلك فإن عدد الساعات التخصصية لبرنامج الدبلوم الخاص قليل علي مدار العامين مقارنة بأقسام الإعلام التربوي المناظرة، وبالتالي يؤدي ذلك لوجود مشكلة في عملية الإعداد الأكاديمي وتأهيل الباحثين لبرنامجي الماجستير والدكتوراه إذا ما تم مقارنته ببعض كليات التربية النوعية في مجال الإعلام. . لم تحدد اللأئحة مسميات المقررات الدراسية الاعلية. في مجال التخصص في السنة الأولي والثانية والمقررات الاختيارية في مجال الإعلام أخر غير وجال التخصص،
من نتائج الجدولين السابقين يتضح أن الطالب يدرس في السنة الأولي (•r) ساعة دراسية منها: (Y) (I) ساعة (نظري) ساعات تطبيقية + (ع) ساعات نظرية للمقرين التربويين (طرق البحث والإحصاء، أصول التربية).

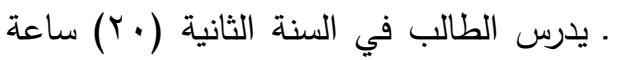
دراسية منها :(ع () ساعة نظري + (7) ساعات تطبيقية + (ع) ساعات نظرية

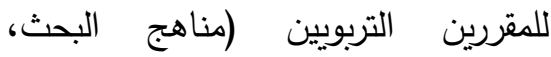
الإحصاء التربوي)، وهذا يعني أن بنهاية سنتي الدبلوم الخاص يكون الطالب درس لئس

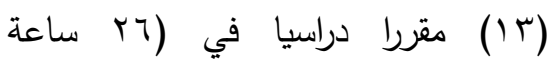
نظرية+ (ع () ساعة تطبيقية) بإجمالي 


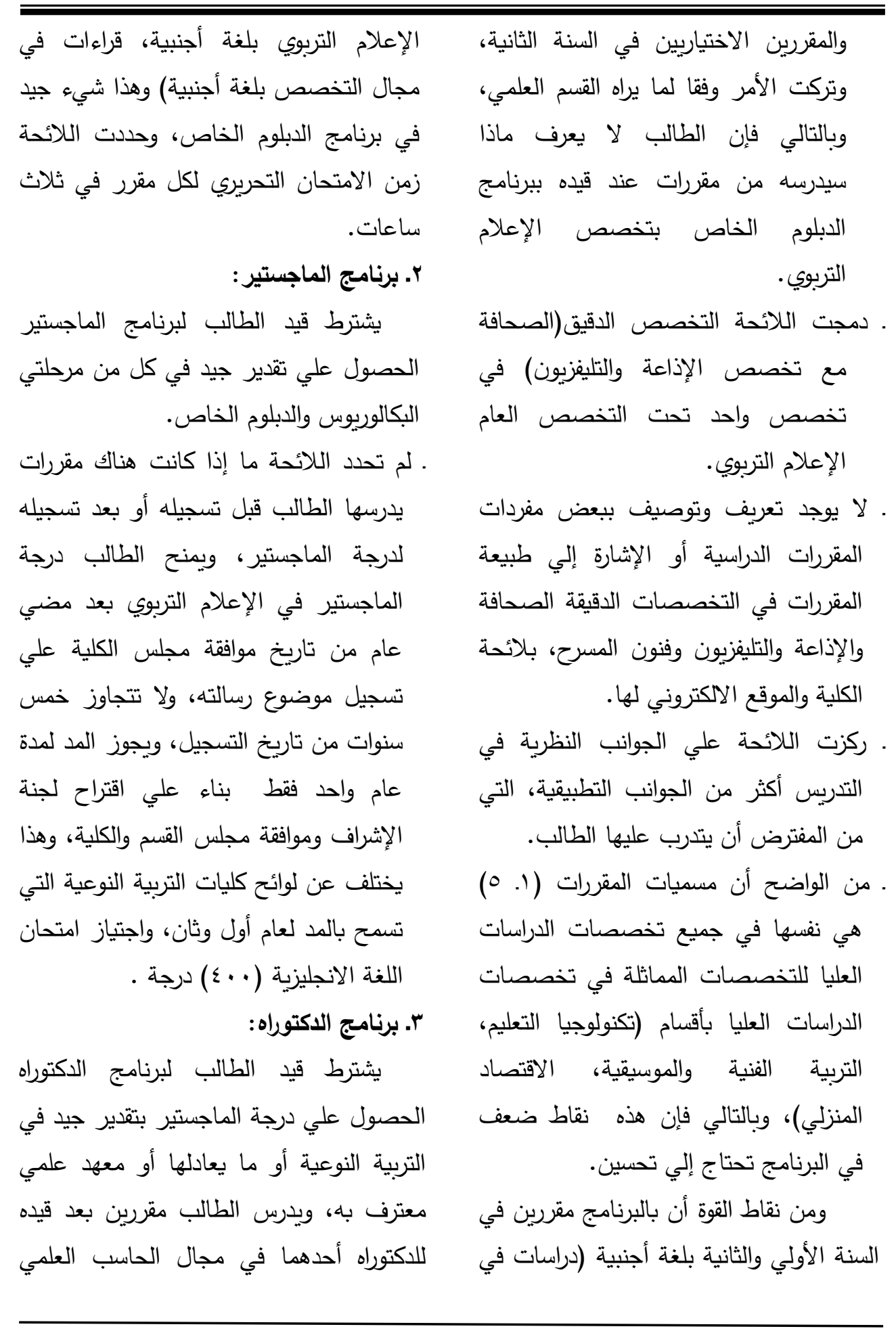




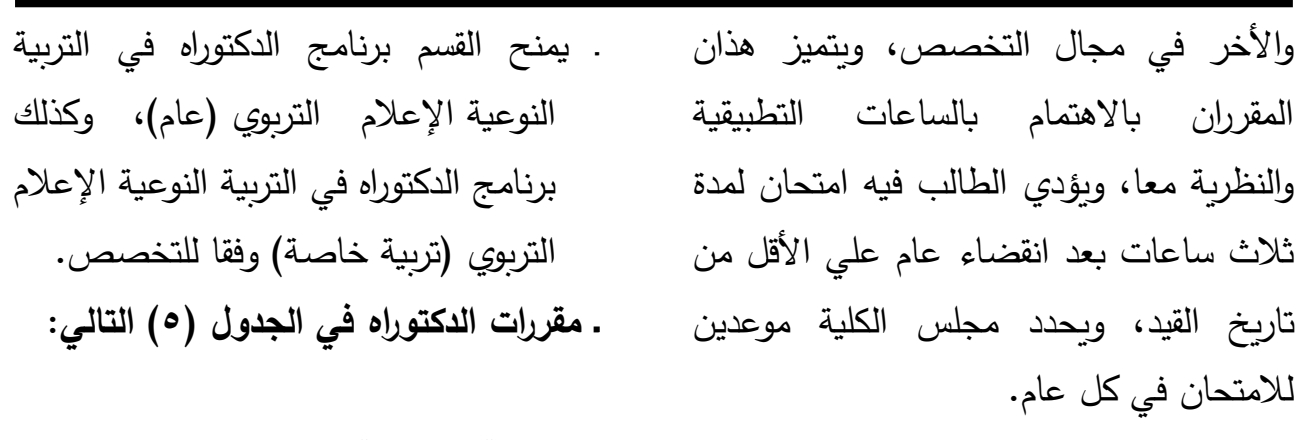

جدول (•) مقرات الاكتوراه بنوعية العباسية

\begin{tabular}{|c|c|c|c|c|c|c|c|c|}
\hline \multicolumn{2}{|c|}{ زمن الامتحان } & \multicolumn{3}{|c|}{ النهاية العظمي للارجات } & \multicolumn{2}{|c|}{ عدد الساعات } & \multirow[t]{2}{*}{ المقررات الدراسية } & s \\
\hline ت تطبيقي & نظري & 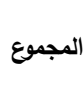 & تطبيقي & سنة & تطبيقي & نظري & & \\
\hline$\wedge$ & $r$ & r.. & 19. & $\varepsilon$. & $\wedge$ & r & مقرر في التخصص الرئيسي & 1 \\
\hline$\varepsilon$ & $r$ & $1 \ldots$ & A. & $r$. & $\varepsilon$ & r & مقرر الحاسب الآلي وتطبيقاته في مجال & r \\
\hline & & $r \ldots$ & $r \leq$. & 7. & ir & $\varepsilon$ & المجموع & \\
\hline
\end{tabular}

وبعد نجاح الطالب في هذه المقررات، . أما عن المشاركين في تدريس المقررات

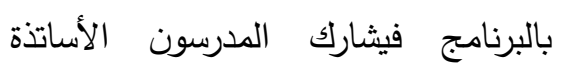
المساعدين، ويسند لهم تدريس الجوانب ومضي عامين علي الأقل من تاريخ موافقة فئاح

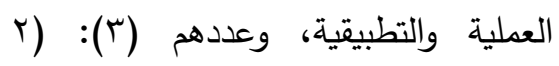
مجلس الكلية علي تسجيل موضوع بحثة يمنح أستاذ مساعد صحافة، أستاذ مساعد وهند الطالب درجة الدكتوراه بعد تقديم رسالة علمية، وبحد أقصي خمس سنوات من تاريخ التسجيل

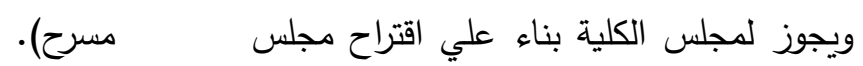
وبالتالي فإن برنامج الإعلام التربوي

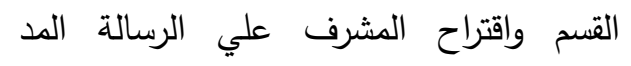

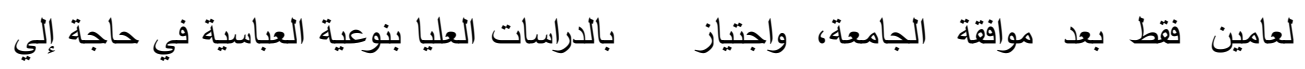

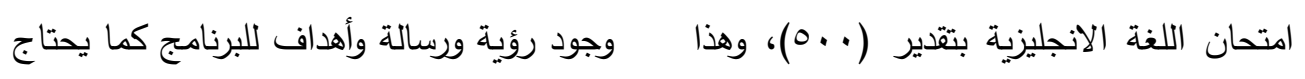

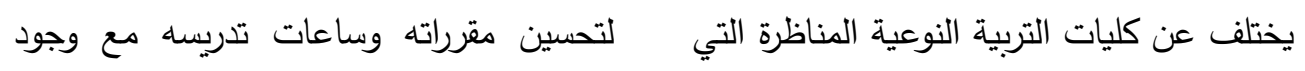
تفرض علي الطلاب دراسة ثلاثة مقررات إستراتيجية للتعليم والتعلم، وإستراتيجية للبحث

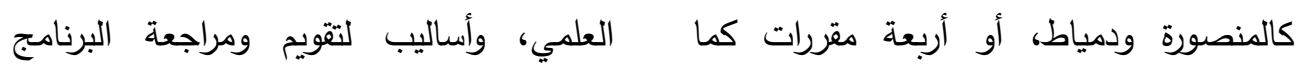
معتمدة ومعلنة لجميع الأطراف المعنية. بنوعية أشمون. . يمنح الطالب درجة (الماجستير، الدكتوراه) ثانبا: كلية التربية النوعية جامعة الزقازيق: بتقدير (مقبول، جيد، جيد جدا، ممتاز) ). 
عامين من خلال أربعة فصول دراسية، تبدأ الدراسة بالفصل الدراسي الأول في شهر

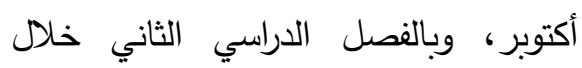
شهر فبراير تتنهي بعقد امتحان في نهاية كل فصل خلال شهري يناير ويونيو، وتكون

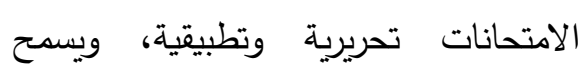
للطالب بالإعادة مرتين فقط ومن الخارج كفرصة ثالثة. ـ يشترط قيد الطالب أن يكون حاصـلا علـي درجـة البكالوريوس أو الليسـانس من احدي لئسي كليات التربية النوعية أو التربية أو الإعـلام

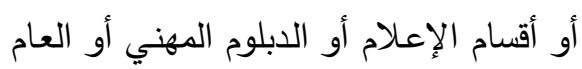

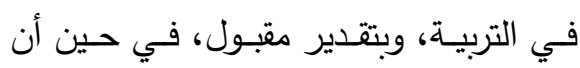
كليات التربية النوعية الأخرى تشترط علي فئي الراغبين في القيد بالدبلوم الخاص أن يكون

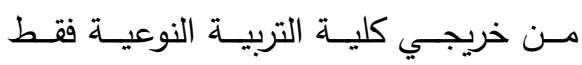
وحاصلا علي تقدير جيد علي الأقل.

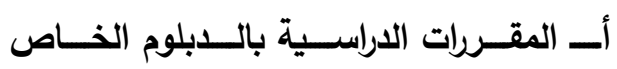
لتخصص الصحافة والإذاعة والتليفزيون: السنة الدراسية الأولي والثانية، ويمكن تتاولها

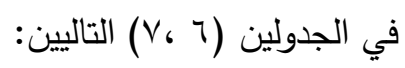

• مسمي القسم بالدراسات العليا: قسم العلوم الاجتماعية والإعلام وبمرحلة البكالوريوس بالستي قسم الإعلام التربوي، وهنا يجب أن إن يكون مسمي القسم في المرحلتين واحدا. • يوجد برنامج دراسات عليا بالقسم وتوجد رؤية

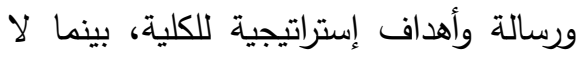
توجد رؤية ورسالة وأهداف لبرنامج الإعلام

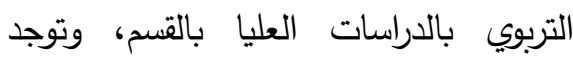

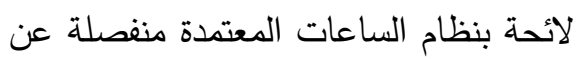
لائحة مرحلة البكالوريوس.

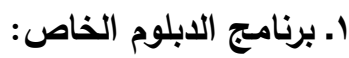
• يمنح القسم درجة الدبلوم الخاص في الإعلام التربوي هما: أ الدبلوم الخاص في الصحافة والإذاعة والتليفزيون. ب ـ الدبلوم الخاص في فنون المسرح. وبالتالي تعد كلية التربية النوعية بالزقازيق من فن لـن الكليات التي تراعي التخصص في برنامج الدبلوم الخاص بالدراسات العليا، وهذه من نقاط القوة في البرنامج. ـ مدة الدراسة ببرنامج الدبلوم الخاص (10) أسبوعا دراسيا، وعلي فصلين دراسيين لمدة لئن 


\begin{tabular}{|c|c|c|c|c|c|c|c|c|c|c|}
\hline \multicolumn{2}{|c|}{ زمن الامتحان } & \multicolumn{4}{|c|}{ درجة نهاية الفصل الدراسي } & \multicolumn{3}{|c|}{ عدد الساعات الدراسية } & \multirow[t]{2}{*}{ المقررات الاراسية } & \multirow[t]{2}{*}{5} \\
\hline تحريري & تطبيقي & 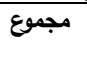 & تحريري & تطبيقي & سنة & تطبيقات & محاضرة & ساعة & & \\
\hline \multicolumn{11}{|c|}{ مقررات أساسية إجبارية (9) ساعات معتمدة } \\
\hline$r$ & $r$ & vo & o. & 10 & 1. & $r$ & $r$ & $r$ & تحريرها وإخراجها الاكترونية & 1 \\
\hline$r$ & - & vo & 10 & - & 1. & - & $r$ & $r$ & $\begin{array}{r}\text { الإنتاج الإذاعي } \\
\text { والتليفزيوني }\end{array}$ & $r$ \\
\hline$r$ & $r$ & vo & 0. & 10 & 1. & $r$ & $r$ & $r$ & مهارات التحريز الإعلامي & $r$ \\
\hline \multicolumn{11}{|c|}{ مقررات اختيارية (يختار الطالب r ا ساعة معتمدة) } \\
\hline$r$ & - & o. & $\varepsilon$ & - & 1. & - & r & $r$ & نظريات الإعاهات الحديثة في & $\varepsilon$ \\
\hline$r$ & $r$ & o. & $r \cdot$ & 1. & 1. & $r$ & 1 & $r$ & تحريز وإخراج الصحف & 0 \\
\hline$r$ & $r$ & 0. & $r$ & 1. & 1. & $r$ & 1 & $r$ & التفاعلية ووسائل الإعلام الحديثة & 7 \\
\hline$r$ & - & 0. & $\varepsilon$ & - & 1. & - & $r$ & $r$ & مهارات الاتصال الفعال & $\mathrm{V}$ \\
\hline$r$ & $r$ & 0 . & $r \cdot$ & 1. & 1. & $r$ & 1 & $r$ & التصوير الإعلامي & $\wedge$ \\
\hline$r$ & $r$ & 0. & $r$. & 1. & 1. & $r$ & 1 & $r$ & الصحافة المتخصصة & 9 \\
\hline$r$ & - & o. & $\varepsilon$ & - & 1. & - & $r$ & $r$ & تكنولوجيا الاتصال الإعلامي & 1. \\
\hline$r$ & $r$ & 0. & $r$. & 1. & 1. & $r$ & 1 & $r$ & الترجمة الإعلامية & 11 \\
\hline$r$ & $r$ & o. & $r$. & 1. & 1. & $r$ & 1 & $r$ & التخطيط للحملات الإعلانية & ir \\
\hline$r$ & - & 0. & $r$. & 1. & 1. & $r$ & 1 & $r$ & فن الإلقاء & ir \\
\hline
\end{tabular}

\begin{tabular}{|c|c|c|c|c|c|c|c|c|c|c|}
\hline \multicolumn{2}{|c|}{ زمن الامتحان } & \multicolumn{4}{|c|}{ درجة نهاية الفصل الدراسي } & \multicolumn{3}{|c|}{ عدد الساعات الدراسية } & \multirow[t]{2}{*}{ المقررات الاراسية } & \multirow[t]{2}{*}{ b } \\
\hline تحريري & تطبيقي & مجموع & تحريري & تطبيقي & سنة & تطبيقات & محاضرة & معتمدة & & \\
\hline \multicolumn{11}{|c|}{ مقررات أساسية إجبارية (ه 1 ) ساعات معتمدة } \\
\hline$r$ & $r$ & vo & 0. & 10 & 1. & $r$ & $r$ & $r$ & مصادر المعلومات & 1 \\
\hline- & - & Vo & - & 10 & 1. & 7 & - & $r$ & مشروع بحث في مجال & $r$ \\
\hline$r$ & $r$ & Vo & 0. & 10 & 1. & r & $r$ & $r$ & قراء التخصص باللغة الأجنبية في & $r$ \\
\hline$r$ & $r$ & Vo & 0. & 10 & 1. & r & $r$ & $r$ & الخطيط وإنتاج برامج & $\varepsilon$ \\
\hline$r$ & - & V० & 70 & - & 1. & - & $r$ & $r$ & وإقارة المؤسسادياتها الإعلامية & 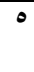 \\
\hline \multicolumn{11}{|c|}{ مقررات اختيارية (يختار الطالب 7 ساعة معتمدة) } \\
\hline$r$ & $r$ & 0. & $r$. & 1. & 1. & $r$ & 1 & $r$ & الالكترابة للصحف والمواقع & 7 \\
\hline$r$ & $r$ & 0. & $r \cdot$ & 1. & 1. & r & 1 & $r$ & إخراج الصحف الورقية & $\mathrm{V}$ \\
\hline$r$ & - & 0. & $\varepsilon$. & - & 1. & - & $r$ & $r$ & أخلاقيات الإعلام & $\wedge$ \\
\hline$r$ & - & 0. & $\varepsilon$. & - & 1. & - & $r$ & $r$ & الوسائط المتعددة & 9 \\
\hline$r$ & $r$ & 0. & $r \cdot$ & 1. & 1. & $r$ & 1 & $r$ & الإخراج الإذاعي & 1. \\
\hline$r$ & - & 0. & $r \cdot$ & 1. & 1. & $r$ & 1 & $r$ & للإذاعة وإلتليفزيون التعليمية & 11 \\
\hline
\end{tabular}


التخصصين عن بعضهما، أيضا نجد غلبة

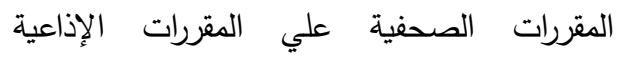
والتليفزيونية في السنة الأولي، فلم يوجد سوي مقرر

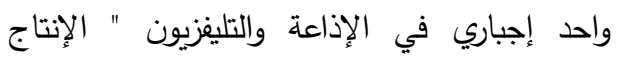
الإذاعي والتليفزيوني"، وجد توازن إلي حد ما الإدي في عرض المقررات العامة والصحفية ومقررات الإذاعة وجدي

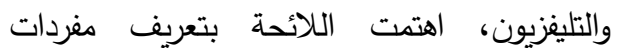
وعناصر المقررات الدراسية، ولكن جاء التعريف ينقصه بعض الموضوعات كمادة الصحافة

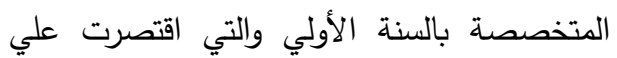

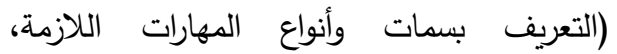
الصحفي المتخصص وسماته) وهي بذلك ركزت التعرئ

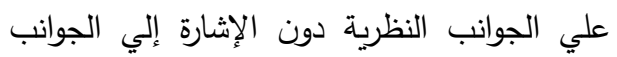

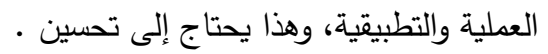

ب المقررات الدراسية لبرنامج الدبلوم الخاص في فنون المسرح السنة الأولي

والثانية:
من نتائج الجدولين السابقين يتضح أن الطالب

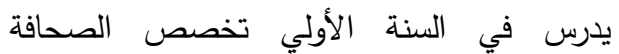

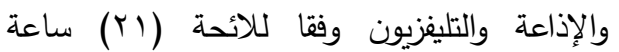

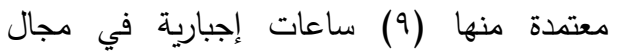

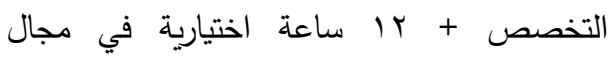
التخصص، وفي السنة الثانية يدرس الطالب (Y) (Y) ساعة معتمدة منها (10) ساعة إجبارية في مجال التخصص + 7 ساعات اختيارية علي فصلين دراسيين. وهذا يعني أن بنهاية سنتي الدبلوم الخاص

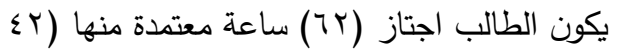
ساعة مقررات تخصصية + +r ساعة مقررات تربوية ونفسية) ويكون الحد الأدنى للعبء الدراسي

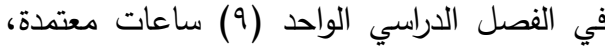

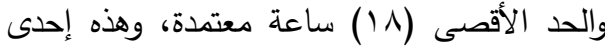
نقاط القوة المميزة لبرنامج الدبلوم الخاص.

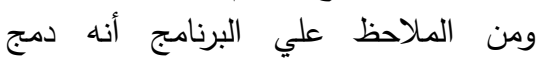
تخصص الصحافة مع الإذاعة والتليفزيون في

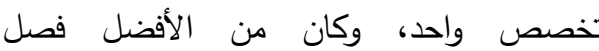

جدول (^) الساعات التدربسية لبرنامج الدبلوم الخاص في (فنون المسرح) السنة الأولي : فصلين دراسيين

\begin{tabular}{|c|c|c|c|c|c|c|c|c|c|c|}
\hline \multicolumn{2}{|c|}{ زمن الامتحان } & \multicolumn{4}{|c|}{ لدرجة نهاية الفصل الدراسي } & \multicolumn{3}{|c|}{ عدد الساعات الدراسية } & \multirow[b]{2}{*}{ 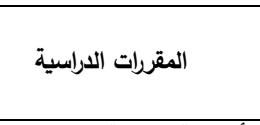 } & \multirow[t]{2}{*}{ م } \\
\hline ت تحريري & تطبيقي & 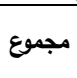 & تحريري & تطبيقي & أعمال & 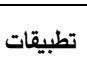 & نظربة & معتمدة & & \\
\hline \multicolumn{11}{|c|}{ مقررات أساسية إجبارية (9) ساعات معتمدة } \\
\hline$r$ & - & Vo & 70 & - & 1. & - & $r$ & $r$ & المسرح التربوي & 1 \\
\hline$r$ & $r$ & Vo & ๑. & 10 & $1 \cdot$ & $r$ & $r$ & $r$ & البناء الدرامي للمسرحية & $r$ \\
\hline$r$ & $r$ & Vo & 0. & 10 & $1 \cdot$ & $r$ & $r$ & $r$ & جماليات العرض المسرحي & $r$ \\
\hline \multicolumn{11}{|c|}{ مقررات اختيارية (يختار الطالب r " ساعة معتمدة) } \\
\hline$r$ & - & 0. & $\varepsilon$ & - & 1. & - & $r$ & $r$ & الدراما الواقعية & $\varepsilon$ \\
\hline$r$ & - & o. & $\varepsilon$. & - & 1. & - & $r$ & $r$ & مسرح التحولات الاجتماعية & 0 \\
\hline$r$ & - & o. & $\varepsilon$ & - & 1. & - & r & r & التمصير والمسرح & 9 \\
\hline$r$ & $r$ & 0. & $r$ & $1 \cdot$ & $1 \cdot$ & r & r & r & المسرح الغنائي للأطفال & $\mathrm{V}$ \\
\hline$r$ & $r$ & 0. & $r$ r. & 1. & 1. & $r$ & 1 & $r$ & كوميديا النقد الاجتماعي & $\wedge$ \\
\hline$r$ & $r$ & o. & $r$. & 1. & 1. & $r$ & 1 & $r$ & المسرح الثعبي & 9 \\
\hline$r$ & $r$ & o. & $r$. & 1. & 1. & $r$ & 1 & $r$ & فن التمثيل الصامت & 1. \\
\hline$r$ & - & 0. & $\varepsilon$ & - & 1. & - & $r$ & $r$ & ترجمة نصوص مسرحية & 11 \\
\hline$r$ & - & $\circ$. & $\varepsilon$ & - & 1. & - & $r$ & $r$ & الارتجال في المسرح & ir \\
\hline$r$ & $r$ & 0. & $r$ & 1. & 1. & $r$ & 1 & $r$ & المسرح السياسي في مصر & 14 \\
\hline
\end{tabular}

جدول (9) الساعات التدريسية لبرنامج الابلوم الخاص في (فنون المسرح) السنة الثانية : فصلين دراسيين 


\begin{tabular}{|c|c|c|c|c|c|c|c|c|c|c|}
\hline \multicolumn{2}{|c|}{ زمن الامتحان } & \multicolumn{4}{|c|}{ درجة نهاية الفصل الدراسي } & \multicolumn{3}{|c|}{ عدد الساعات الاراسية } & \multirow{2}{*}{ المقررات الدراسية } & \multirow[t]{2}{*}{ b } \\
\hline تحريري & تطبيقي & مجموع & ت تحريري & تطبيقي & أعمال & تطبيقات & محاضرة & معتمدة & & \\
\hline \multicolumn{11}{|c|}{ مقررات أساسية إجبارية (0 10) ساعة معتمدة } \\
\hline$r$ & $r$ & vo & 0 . & 10 & 1. & $r$ & $r$ & $r$ & المسرحية المدرسية إنتاجها & 1 \\
\hline- & $\varepsilon$ & vo & - & 90 & 1. & 7 & - & $r$ & مشروع بحث في مجال & $r$ \\
\hline$r$ & $r$ & vo & o. & 10 & 1. & $r$ & $r$ & $r$ & قراءات باللغة الانجليزية في & $r$ \\
\hline$r$ & $r$ & vo & 0 . & 10 & 1. & r & $r$ & $r$ & تحليل ونقد مسرحي & $\varepsilon$ \\
\hline$r$ & r & vo & o. & 10 & 1. & r & $r$ & $r$ & الدراما الشعرية & 0 \\
\hline \multicolumn{11}{|c|}{ مقررات اختيارية (يختار الطالب \ ساعات معتمدة) } \\
\hline r & $r$ & 0 . & $r$ & 1. & 1. & r & 1 & $r$ & التراث الثعبي ومسرح الطفل & 1 \\
\hline r & r & o. & $r$. & 1. & 1. & r & 1 & r & فن الإلقاء المسرحي & $\mathrm{v}$ \\
\hline$r$ & $r$ & o. & $r$. & 1. & 1. & $r$ & 1 & $r$ & إعداد الممثل المسرحي & $\wedge$ \\
\hline$r$ & - & o. & $\varepsilon$ & - & 1. & - & $r$ & $r$ & سينما الأطفال س س & 9 \\
\hline r & r & 0. & $r$. & 1. & 1. & r & 1 & $r$ & مسرح العرائس وخيال الظل & 1. \\
\hline$r$ & $r$ & o. & $r$. & 1. & 1. & $r$ & 1 & $r$ & علم العلامات المسرحية & 11 \\
\hline
\end{tabular}

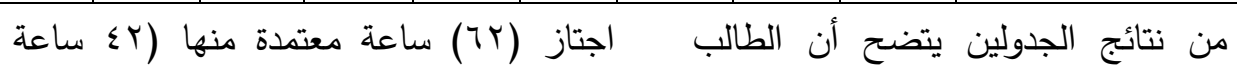

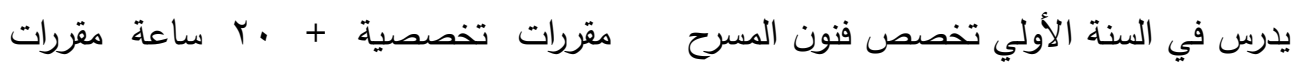

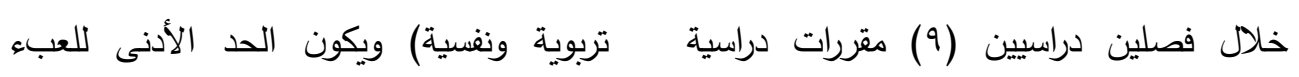

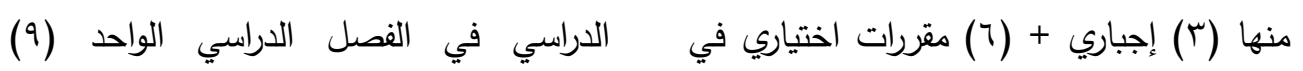

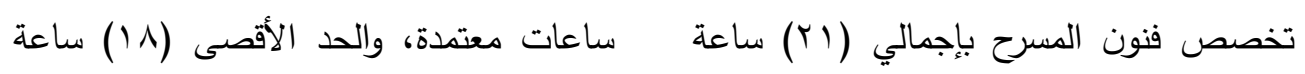
معتمدة منها (9) ساعات إجبارية في مجال معتمدة كما جاء بلائحة الكلية. تخصص المسرح + r ا ساعة اختيارية في يوجد مقرر واحد هو سينما الأطفال من المواد

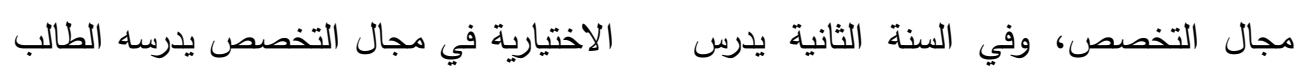

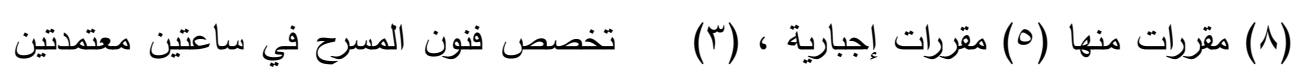

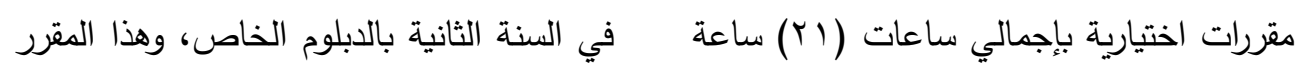

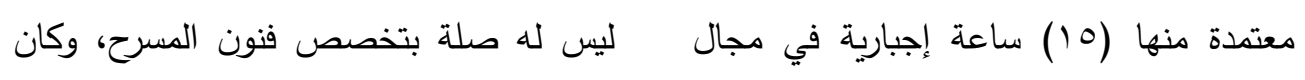

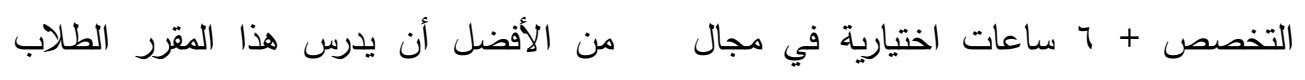

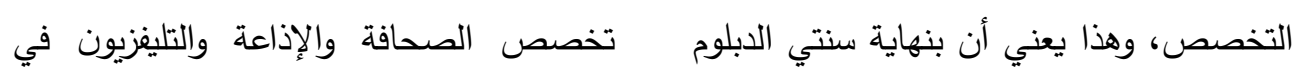

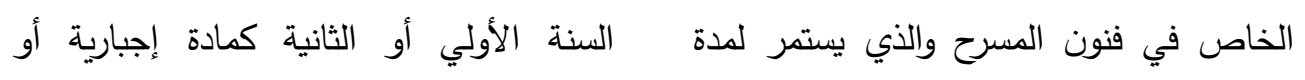
عامين في أربعة فصول دراسية يكون الطالب اختيارية. 
- وجـد تعريـف لمفـردات وعناصـر المقـررات الجوانب النظريـة دون الإثـارة إلـي الجوانب

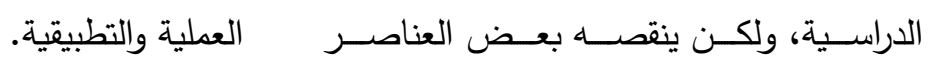

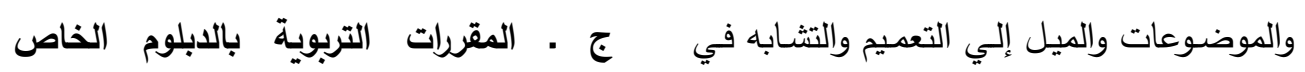
التوصيف كمقرر (المسرحية المدرسية إنتاجها لتخصي والهي الصحافة والإذاعة والتليفزيون،

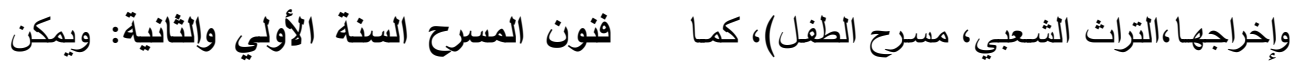

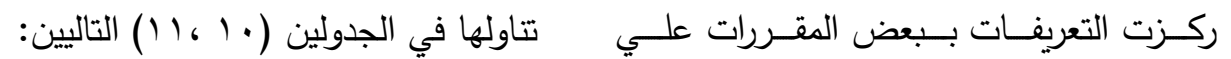

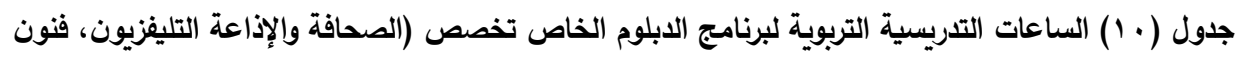
المسرح) السنة الأولي (نظام الفصلين الدراسيين)

\begin{tabular}{|c|c|c|c|c|c|c|c|c|c|c|c|}
\hline \multicolumn{2}{|c|}{ زمن الامتحان } & \multicolumn{4}{|c|}{ درجة نهاية الفصل الدراسي } & \multicolumn{3}{|c|}{ عدد الساعات الاراسية } & \multirow{2}{*}{\multicolumn{2}{|c|}{ المقررات الدراسية }} & \multirow[t]{2}{*}{ s } \\
\hline 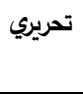 & تطبيقي & 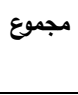 & 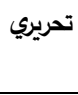 & تطبيقي & سنة & تطبيقات & نظرية & ستمدة & & & \\
\hline \multicolumn{12}{|c|}{ مقررات أساسية إجبارية (V) ساعة معتمدة } \\
\hline r & r & vo & ○. & 10 & 1. & r & r & $r$ & \multicolumn{2}{|c|}{ التربية ومشكلات المجتمع } & 1 \\
\hline r & - & o. & $\varepsilon$. & - & 1. & - & r & r & \multicolumn{2}{|c|}{ التخطيط التعليمي } & r \\
\hline r & - & ○. & $\varepsilon$ & - & 1. & - & r & r & \multicolumn{2}{|c|}{ النفس التربوي الحايثة في علم } & $r$ \\
\hline \multicolumn{12}{|c|}{ مقررات اختيارية (يختار الطالب ؛ ساعات معتمدة) } \\
\hline r & - & ๑. & $\varepsilon$. & - & 1. & - & r & r & إلتعليمية المؤسسات & \multirow[t]{2}{*}{ تخصص } & $\varepsilon$ \\
\hline$r$ & - & o. & $\varepsilon$. & - & 1. & - & r & r & تاريخ ورواد التربية & & 0 \\
\hline$r$ & - & o. & $\varepsilon$. & - & 1. & - & r & r & صعوبات التعلم & \multirow{2}{*}{ تخصص } & 7 \\
\hline r & - & o. & $\varepsilon$. & - & 1. & - & r & r & $\begin{array}{l}\text { تعديل السلوك } \\
\text { (برامج وفنيات) }\end{array}$ & & $v$ \\
\hline
\end{tabular}

جدول (1') الساعات التدريسية التزبوية لبرنامج الدبلوم الخاص تخصص (الصحافة والإذاعة التليفزيون، فنون المسرح) السنة الثانية (نظام الفصلين الدراسيين)

\begin{tabular}{|c|c|c|c|c|c|c|c|c|c|c|}
\hline \multicolumn{2}{|c|}{ زمن الامتحان } & \multicolumn{4}{|c|}{ درجة نهاية الفصل الدراسي } & \multicolumn{3}{|c|}{ عدد الساعات اللراسية } & \multirow[t]{2}{*}{ المقررات الدراسية } & \multirow[t]{2}{*}{ p } \\
\hline تحريري & تطبيقي & مجموع & تحريري & تطبيقي & سنة أعمال & تطبيقات & مخاضرة & سعتدة & & \\
\hline \multicolumn{11}{|c|}{ مقررات أساسية إجبارية (v) ساعة معتدة } \\
\hline
\end{tabular}




\begin{tabular}{|c|c|c|c|c|c|c|c|c|c|c|c|}
\hline$r$ & r & vo & o. & 10 & 1. & r & 1 & $r$ & \multicolumn{2}{|c|}{ مالنفاهج البحث التربوي } & 1 \\
\hline$r$ & - & o. & $\varepsilon$. & - & 1. & - & r & r & \multicolumn{2}{|c|}{ قضايا ورؤى فلسفية في } & r \\
\hline \multicolumn{12}{|c|}{ مقررات اختيارية (يختار الطالب ؛ ساعات متمدة) } \\
\hline r & - & o. & $\varepsilon$. & - & 1. & - & r & r & التعليكولوجية الفروقية & تخصص & $r$ \\
\hline r & - & o. & $\varepsilon$. & - & 1. & - & r & r & التربوي الإحصاء & & $\varepsilon$ \\
\hline r & - & ๑. & $\varepsilon$ & - & 1. & - & r & r & والاعتماد & تخصص & • \\
\hline$r$ & - & 0. & $\varepsilon$ & - & 1. & - & r & $r$ & التالديتقبلية في & & 7 \\
\hline
\end{tabular}

من هذين الجدولين نجد أن الطالب يدرس يوجد توصيف جيد للمقررات التربوية

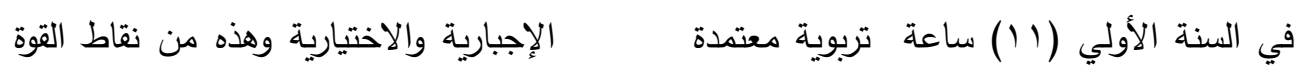

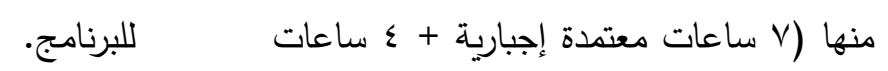

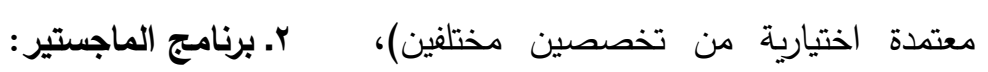
يمنح القسم درجة الماجستير في التربية معتمدة تربوية منها (0 ساعات معتمدة النوعية في تخصص الخصاعة العلوم الاجتماعية

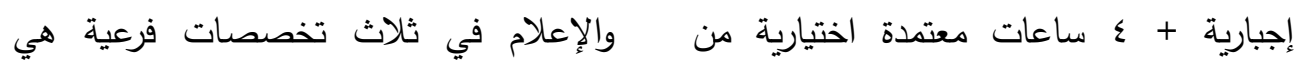

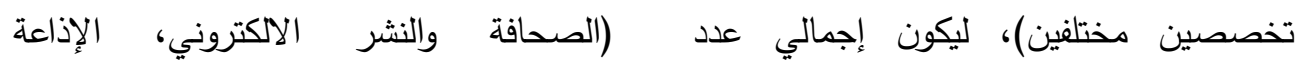
الساعات التربوية في السنة الأولي والثانية والتليفزيون، فنون المسرح).

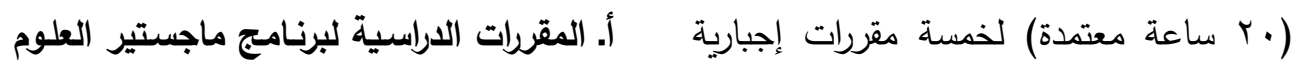
وأربعة اختيارية بإجمالي مقررات تربوية (9 و ل مقررات علي مدار الفصول الدراسية الأربعة النشر الإلكتروني:

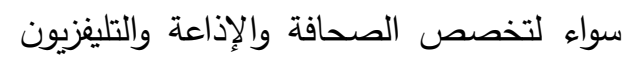
أو لتخصص فنون المسرح بالدبلوم الخاص. جدول (r ا I) الساعات التدريسية لبرنامج الماجستير في (الصحافة والنشر الاكتروني)

\begin{tabular}{|c|c|c|c|c|c|c|c|c|c|}
\hline \multirow{2}{*}{ الامتحان } & \multicolumn{4}{|c|}{ درجة نهاية الفصل الاراسي } & \multicolumn{3}{|c|}{ عدا لعاعات الدراسية } & \multirow[t]{2}{*}{ المقررات الاراسية } & \multirow[t]{2}{*}{ s } \\
\hline & مجموع & تحريري & تطبيقي & سنة أعمال & تطبيقات & محاضرة & ستاعة & & \\
\hline$r$ & $\circ$. & $\varepsilon$ & - & 1. & - & $r$ & $r$ & قراءات باللغة الأجنبية في & 1 \\
\hline
\end{tabular}




\begin{tabular}{|c|c|c|c|c|c|c|c|c|c|}
\hline & & & & & & & & مجال الصحافة والنشر & \\
\hline & o. & - & $\varepsilon$. & 1. & $\varepsilon$ & - & r & الصحافة بحث والنشناقشات في & r \\
\hline & & & & & & \multicolumn{4}{|c|}{ يختار الطالب مقررين دراسيين بما يعادل (؛) ساعات } \\
\hline r & o. & $\varepsilon$ & - & 1. & - & r & r & الإعلام الدولي والععبي & $r$ \\
\hline r & o. & $\varepsilon$. & - & 1. & - & r & r & نظريات الإعلام & $\varepsilon$ \\
\hline r & o. & $\varepsilon$. & - & 1. & - & r & r & التشربعات الصحفية & ○ \\
\hline
\end{tabular}

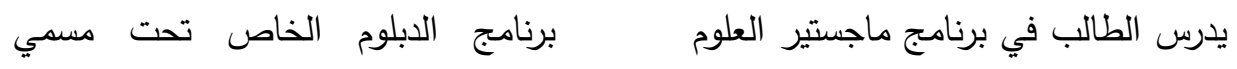
(الاتجاهات الحديثة في نظريات الإعلام، الاجتماعية والإعلام ت تخصص الصحافة

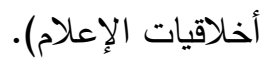

والنشر الالكتروني (^) ساعات معتمدة إلي

· جميع مقررات الماجستير كلها مقررات نظرية الهم جانب رسالته . (1) - (1) تفتقد الجوانب التطبيقية ما عدا مقرر حلقة • من الملاحظ أن المقررات الاختيارية الثلاث بحث ومناقشات في الصحافة والنشر والتي يختار الطالب منها مقررين دراسيين الالكتروني (1) لها جانب تطبيقي في في أربع ساعات هي مقررات من أربع ساعات. المفترض أن درسها الطالب في مرحلة البكالوريوس، وكان من الأفضل إضافة المقررات الدراسية لبرنامج ماجستير مقررات تتتاول الإعلام الجديد خاصة وأن العلوم الاجتماعية والإعلام تخصص الطالب قد درس هذين المقررين في السنة الإذاعة والتليفزيون: الأولي والثانية كمقررات اختيارية في فيرية

جدول (r ا I) الساعات التدريسية لبرنامج الماجستير في (الإذاعة والتليفزيون)

\begin{tabular}{|c|c|c|c|c|c|c|c|c|c|}
\hline \multirow{2}{*}{ زمن الامتحان } & \multicolumn{4}{|c|}{ درجة نهاية الفصل الاراسي } & \multicolumn{3}{|c|}{ عدد الساعات الدراسية } & \multirow[t]{2}{*}{ المقررات الاراسية } & \multirow[t]{2}{*}{ p } \\
\hline & مجموع & تحرير & تطبيقي & 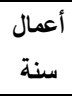 & تطبيقات & محاضرة & ستمدة & & \\
\hline$r$ & $\therefore$. & $\varepsilon$ & - & 1. & - & $r$ & r & 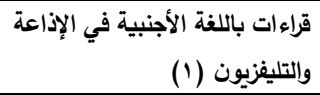 & 1 \\
\hline & 0. & - & $\varepsilon$ & 1. & $\varepsilon$ & - & r & حلقة بحث ومناقشات في مجال & r \\
\hline
\end{tabular}




\begin{tabular}{|c|c|c|c|c|c|c|c|c|c|}
\hline & & & & & & & & الإذاعة والتليفزيون & \\
\hline \multicolumn{10}{|c|}{ يختار الطالب مقررين دراسيين بما يعادل ( ؛) ساعات } \\
\hline r & ๑. & $\varepsilon$. & - & 1. & - & r & $r$ & دراسات في الإذاعة والتليفزيون & $r$ \\
\hline r & ๑. & $\varepsilon$. & - & 1. & - & r & r & البرامج المتخصصة & $\varepsilon$ \\
\hline r & ๑. & $\varepsilon$. & - & 1. & - & r & r & الإذاعة والتسجيلات الصوتية & • \\
\hline
\end{tabular}

يدرس الطالب لبرنامج ماجستير العلوم التليفزيون (1) لهاعية جانب تطبيقي في أربع

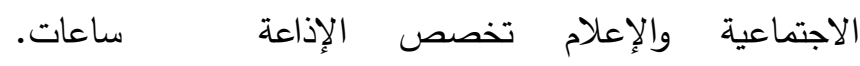

والتليفزيون (^) ساعات معتمدة إلي جانب الإعلاع ج - المقرات الدراسية لبرنامج ماجستير

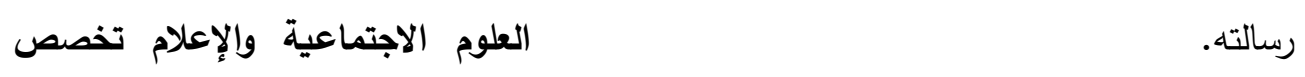

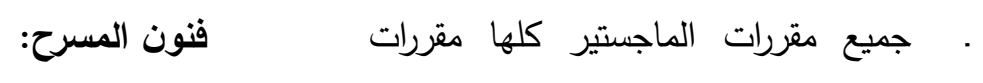

نظرية تثتقد الجوانب العملية ما عدا مقرر

حلقة بحث ومناقثات في مجال الإذاعة

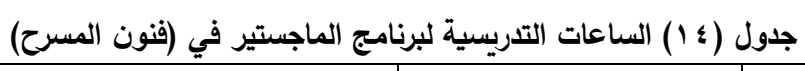

\begin{tabular}{|c|c|c|c|c|c|c|c|c|c|c|}
\hline \multicolumn{2}{|c|}{ زمن الامتحان } & \multicolumn{4}{|c|}{ درجة نهاية الفصل الدراسي } & \multicolumn{3}{|c|}{ عدد الساعات الاراسية } & \multirow[t]{2}{*}{ المقررات الدراسية } & \multirow[t]{2}{*}{ b } \\
\hline ت تحريري & تطبيقي & 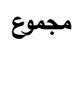 & 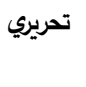 & تطبيقي & أعمال & تطبيقات & محاضرة & سعاعة & & \\
\hline r & - & o. & $\varepsilon$. & - & 1. & - & r & r & مجاءات باللغة الأجنبية في & 1 \\
\hline- & - & o. & - & $\leq$. & 1. & $\varepsilon$ & - & $r$ & حلقة بحث ومناقثات في & r \\
\hline \multicolumn{11}{|c|}{ يختار الطالب مقررين دراسيين بما يعادل (؛ ) ساعات } \\
\hline r & r & o. & $r$ r. & - & 1. & r & 1 & r & الزمان والمكان المسرحي & $r$ \\
\hline r & r & o. & r. & - & 1. & r & 1 & r & الإبداع المسرحي وسلطة & $\varepsilon$ \\
\hline r & r & o. & r. & - & 1. & 1 & 1 & r & المسرح اليوناني والروماني & 0 \\
\hline
\end{tabular}

وكان من الأفضل إضافة مقرر أخر

كالاتجاهات الحديثة في الإخراج المسرحي

يدرس الطالب في برنامج ماجستير العلوم

أو الاتجاهات الحديثة في المسرح التربوي

الاجتماعية والإعلام تخصص فنون المسرح

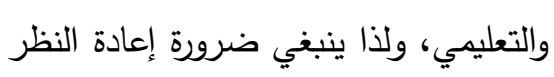

(^) ساعات معتمدة إلي جانب رسالته.

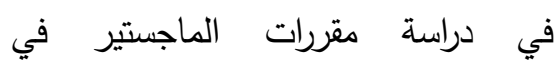

التخصصات الثلاثة، ومحاولة تعديلها

لمنع وجود تكرار بين ما درسه الطالب في

مرحلة البكالوريوس والدراسات العليا.

• ومما يؤخذ علي المقرر الاختياري المسرح

اليوناني والروماني والذي يتناول نثأة

التراجيديا والكوميديا وأهم رواد كل منهما

ونثأة الدراما الرومانية من المفترض أن والن

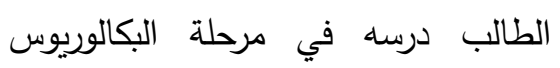


دراسيا، ولا تتم المناقثة إلا بعد مضي عامين

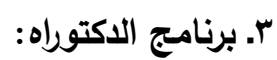

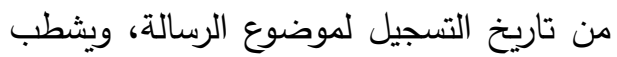
يمنح القسم درجة الدكتوراه في تخصص لتصدي قيد الطالب بعد مرور ثلاث سنوات من تاريخ العلوم الاجتماعية والإعلام في ثلاثية تسجيله ما لم يقدم عذرا مقبولا، ويلغي قيده إذا تخصصات (الصحافة والنشر الالكتروني، انقضت ست سنوات علي تسجيله دون تقديم عذر مقبول إلا إذا رأي مجلس الكلية الإبقاء

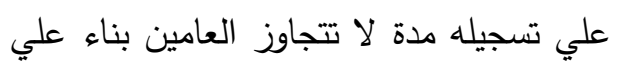
تقرير من المشرفين وموافقة مجلس القسم. ـ المقــرات الدراســية لبرنـــامـج الــدكتوراه

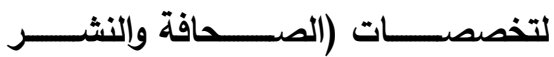
الاككترونـي، الإذاعـة والتليفزيـون، فنـون المسـرح): ويمكن تتاولهـا فـي الجـاول

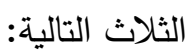
الإذاعة والتليفزيون، فنون المسرح).

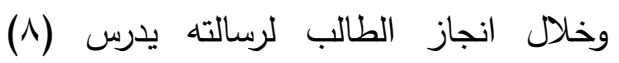
ساعات معتمدة منها حلقة بحث ومناقثات سيمنار (Y ساعة معتمدة) لمدة ستة أشهر علي الأقل من تاريخ موافقة مجلس الكلية علي تسجيل المقررات الدراسية لبرنامج الدكتوراه، ويشترط حصول الطالب علي (تقدير جيد c)

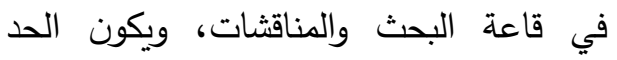

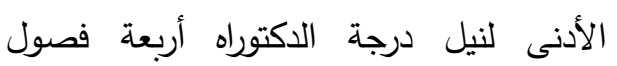
دراسية والحد الأقصى هو اثنا عشر فصلا

\begin{tabular}{|c|c|c|c|c|c|c|c|c|c|c|}
\hline \multicolumn{2}{|c|}{ زمن الامتحان } & \multicolumn{4}{|c|}{ لدرجة نهاية الفصل الدراسي } & \multicolumn{3}{|c|}{ عدد الساعات الدراسية } & \multirow[t]{2}{*}{ المقررات الدراسية } & \multirow[t]{2}{*}{ p } \\
\hline تحريري & تطبيقي & 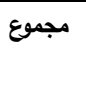 & تحريري & تطبيقي & أعمال & | تطبيقات & ن محاضرة & معتدة & & \\
\hline r & - & $\circ$. & ؛. & - & 1. & - & r & r & قاراءات باللغة الأجنبية في مجال الألنشتروني & 1 \\
\hline- & - & ๑. & - & ؛. & 1. & $\varepsilon$ & - & r & حلقة بحث ومناقشات في الصحافة & $r$ \\
\hline \multicolumn{11}{|c|}{ مقررات اختيارية يختار الطالب مقررين دراسيين بما يعادل (؛) ساعات } \\
\hline r & - & ○. & . & - & 1. & - & r & r & الاتجاهات المهنية في التتريس & $r$ \\
\hline r & - & o. & ؛. & - & 1. & _ & r & r & الصحافة الاستقصائية & 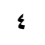 \\
\hline
\end{tabular}




\begin{tabular}{|c|c|c|c|c|c|c|c|c|c|c|}
\hline r & - & o. & $\varepsilon$. & - & 1. & - & r & r & الحملة الصحفية & • \\
\hline \multicolumn{11}{|c|}{ جدول (ד 1) الساعات التدريسية لبرنامج الدكتوراه في (الإذاعة والتليفزيون) } \\
\hline \multicolumn{2}{|c|}{ 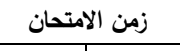 } & \multicolumn{4}{|c|}{ ل درجة نهاية الفصل الدراسي } & \multicolumn{3}{|c|}{ عدد الساعات الاراسية } & \multirow[t]{2}{*}{ 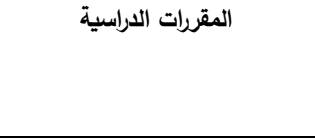 } & \multirow[t]{2}{*}{ r } \\
\hline تحريري & تطبيقي & 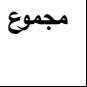 & ت تحريري & تطبيقي & سنة & تطبيقات & محاضرة & معتمدة & & \\
\hline r & - & o. & $\varepsilon$. & - & 1. & - & $r$ & r & 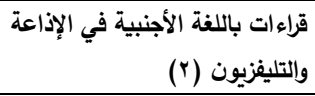 & 1 \\
\hline- & - & o. & - & 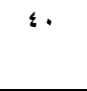 & 1. & $\varepsilon$ & - & $r$ & 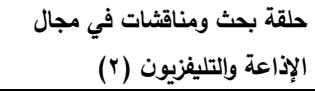 & $r$ \\
\hline \multicolumn{11}{|c|}{ يختار الطالب مقرين دراسيين بما يعادل (؛ ) ساعات } \\
\hline r & r & o. & r. & 1. & 1. & $r$ & 1 & r & البرامج الإخبارية & $r$ \\
\hline$r$ & r & o. & $r$. & 1. & 1. & r & 1 & $r$ & التصوير الإذاعي والتليفزيوني & $\varepsilon$ \\
\hline r & $-r$ & o. & $r$. & 1. & 1. & $r$ & 1 & $r$ & إنتاج برامج الفيديو والتليفزيون & • \\
\hline
\end{tabular}

جدول (IV) الساعات التدريسية لبرنامج الدكتوراه في (فنون المسرح)

\begin{tabular}{|c|c|c|c|c|c|c|c|c|c|c|}
\hline \multicolumn{2}{|c|}{ زمن الامتحان } & \multicolumn{4}{|c|}{ درجة نهاية الفصل الدراسي } & \multicolumn{3}{|c|}{ عدد الساعات الدراسية } & \multirow[t]{2}{*}{ المقررات الداسية } & \multirow[t]{2}{*}{ b } \\
\hline 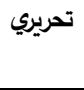 & تطبيقي & 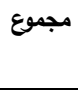 & 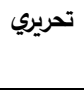 & تطبيقي & سنة & ت تطبيقات & محاضرة & متمدة & & \\
\hline r & - & $\circ$. & $\varepsilon$ & - & 1. & - & r & r & 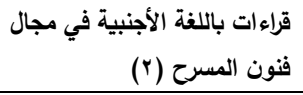 & 1 \\
\hline- & - & $\circ$. & - & $\varepsilon$ & 1. & $\varepsilon$ & - & r & 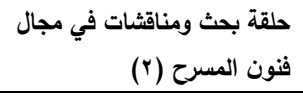 & r \\
\hline \multicolumn{11}{|c|}{ يختار الطالب مقررين دراسيين بما يعادل (؛) ساعات } \\
\hline r & r & $\triangle$. & $r \cdot$ & 1. & 1. & r & 1 & r & ومناهجه النقد الأدبي الحديث(أصوله & $r$ \\
\hline$r$ & r & $\therefore$. & $r \cdot$ & 1. & 1. & r & 1 & $r$ & المسرح التجريبي & $\varepsilon$ \\
\hline r & $r$ & 0. & $r$. & 1. & 1. & 1 & 1 & $r$ & مسرح العصور الوسطي وعصر & - \\
\hline
\end{tabular}

من هذه الجداول الثلاثة يتضح خلو المسرح علي مقررات نظرية وتطبيقية وهذا

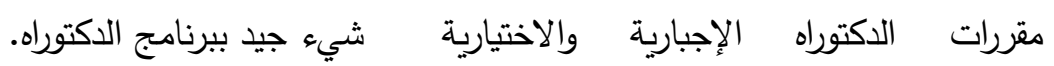

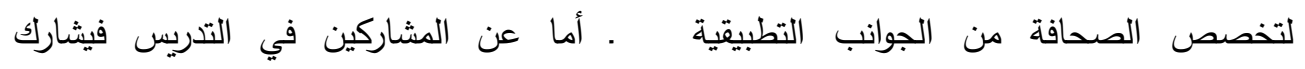
والعملية ماعدا مقرر (حلقة بحث ومناقثات المدرسون في تدريس المقررات الدراسية

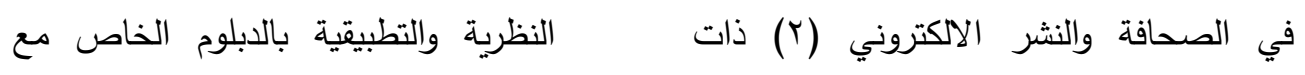

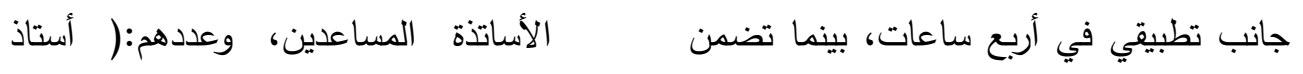

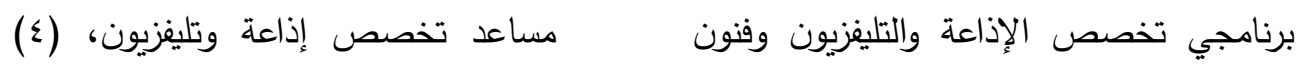


. يدرس الطالب برنامج الدبلوم الخاص في التربية النوعية في ثلاثة فصول دراسية، يدرس خلالها (Y (1) 1) ساعة معتمدة في الفصل الدراسي الواحد ونصفها في الفصل الدراسي الصيفي، علي ألا يدرس الطالب

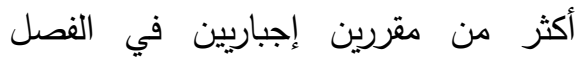
الدراسي الواحد. . مدة الدراسة بكل من الفصل الدراسي الأول والثاني (الخريف والربيع) (10) أسبوعا دراسيا، وأسبوعان للادتحانات التطبيقية والثفهية والتحريرية، أما الفصل الدراسي الصيفي والذي يبدأ من شهر يوليو مدته

$$
\text { • (^) }
$$

يحـق للطالب إعـادة التسـجيل فـي أي مقـرر

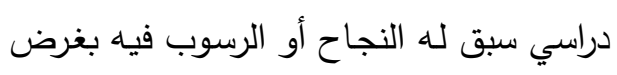

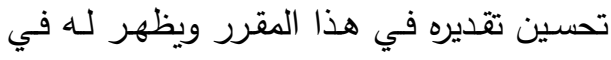
شهادته التقدير الأعلى، وهذه إحدى نقاط القوة غير المتوفرة في برامج الإعلام التربوي بكليات

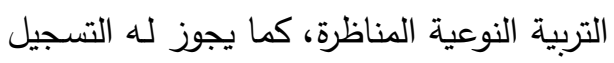

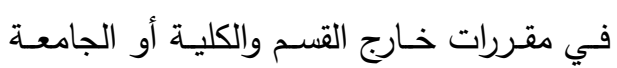
طالما أنها من بين برنامجه الدراسي بعد موافقة

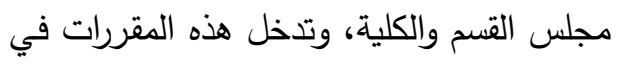
حساب المتوسط التراكمي للدرجات GPA. ورغم أن لائحة الكلية أقرت ذلك الشرط، لأل الثرات لكن يبقي السؤال: هل تسمح لوائح الكليات

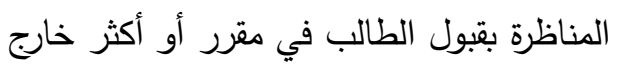
الكلية المقيد بها؟!، رغم أن كل كليه تلزم
مدرسين مسرح + أستاذ مساعد منتدب

$$
\text { مسرح التربوي، (r) صحافة ). }
$$

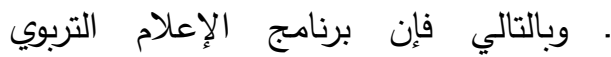
بالدراسات العليا بنوعية الزقازيق في حاجة إلي وجود رؤية ورسالة وأهداف للبرنامج كما يحتاج لتحسين مقرراته وساعات وله ولهات تدريسه مع وجود إستراتيجية للتعليم

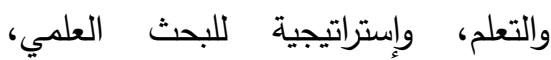
وأساليب لتقويم ومراجعة البرنامج معتمدة ومعلنة لجميع الأطراف المعنية.

ثالثا: كلية التربية النو عية جامعة بنها:

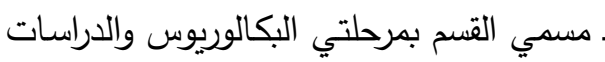

$$
\text { العليا، قسم الإعلام التربوي. }
$$

• يوجد برنامج للإعلام التربوي بالدراسات العليا.

$$
\text { (الدبلوم، الماجستير، الدكتوراه). }
$$

. لا توجد رؤية ورسالة وأهداف لبرنامج الإعلام

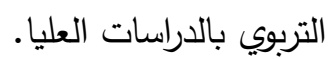

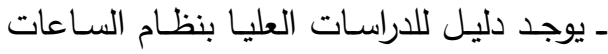
المعتمدة ومعلن علي الموقـع الالكترونـي لئي

\section{للكلية.}

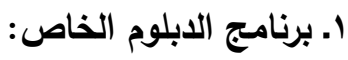

يمنح القسم درجة الدبلوم الخاص في التربية النوعية تخصص الإعلام التربوي حال إكمال الطالب دراسة جميع المقررات المحددة لارجة الماجستير، والمقررات الثلاثة الأساسية للتسجيل لدرجة الماجستير. 
الطالب عند قيده ببرنامج الدبلوم بتوقيع إقرار مجموع ساعات جميع الدقررات الدراسية، أنه غير مقيد بالدراسات العليا بأي كلية أخري. وكل ساعة دراسية تكافئ أربعة نقاط.

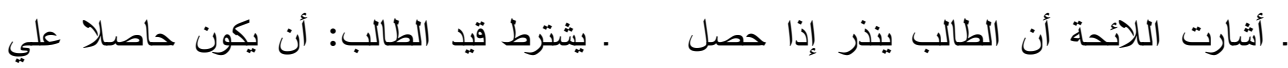

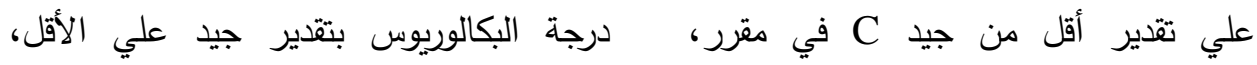

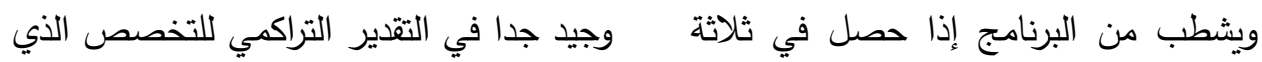

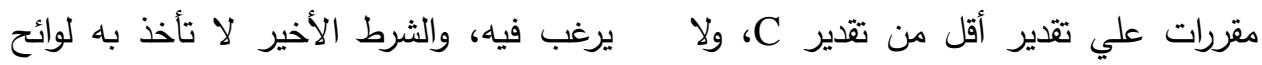

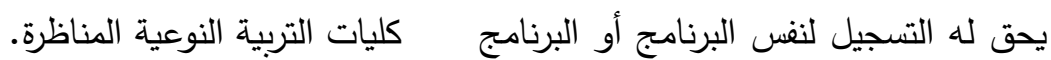

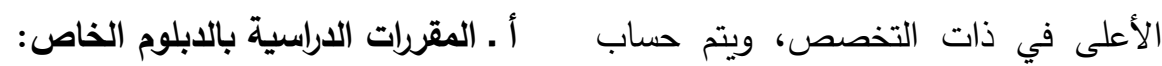

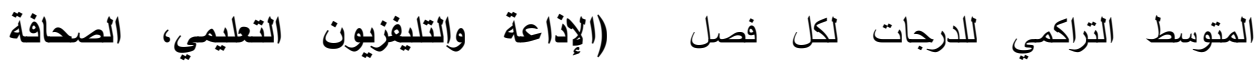
دراسي والمتوسط التراكمي النهائي : لمدرسية، مسرح مدرسي): ويمكن تتاولها في = CGPA المقررات الدراسية التي حصل عليها الطالب

جدول (1 ا) مقرات الماجستير في الإعلام التربوي " الإذاعة والتليفزيون التعليمي،الصحافة المدرسية، مسرح

\begin{tabular}{|c|c|c|c|}
\hline \multicolumn{4}{|c|}{ مدرسي) } \\
\hline المقررات التربوية الإجبارية & م & المقررات التخصصية الإجبارية & م \\
\hline طرق البحث وتحليل البيانات & 1 & تخطيط وإنتاج برامج الإذاعة المدرسية & 1 \\
\hline نظريات الاتصال & $r$ & إنتاج البرامج التليفزيونية للأطفال & $r$ \\
\hline سيكولوجية الإبداع & $r$ & المسرحيات المدرسية إنتاجها وإخراجها & $r$ \\
\hline الإعلام التربوي المقارن & $\varepsilon$ & الصحافة الالكترونية & $\varepsilon$ \\
\hline \multicolumn{2}{|l|}{ مقررات أساسية للتسجيل للماجستير } & الفيلم الاكتروني & 0 \\
\hline قراءات باللغة الانجليزية في التخصص & 1 & \multirow[t]{3}{*}{ | التليفزيون التعليمي } & 1 \\
\hline حلقة مناقثة في مجال التخصص & r & & \\
\hline بحوث في مجال التخصص & $r$ & & \\
\hline \multicolumn{4}{|c|}{ الدقرات التخصصية الاختيارية } \\
\hline الإعلام وقضايا المجتمع & 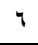 & إعاد البرامج التعليمية لوسائل الإعلام & 1 \\
\hline
\end{tabular}




\begin{tabular}{|c|c|c|c|}
\hline الوسائط المتعددة في الإعلام التربوي & $v$ & الموضوع في وسائل الإعلام & r \\
\hline أدب مقارن & $\wedge$ & أدب الأطفال المقارن & $r$ \\
\hline \multirow{2}{*}{ حاسب ألي في مجال التخصص } & \multirow[t]{2}{*}{9} & التذوق الفني & $\varepsilon$ \\
\hline & & التذوق الموسيقي & 。 \\
\hline
\end{tabular}

من نتائج هذا الجدول يدرس الطالب في معاهد وكليات الإعلام وأقسام الإعلام

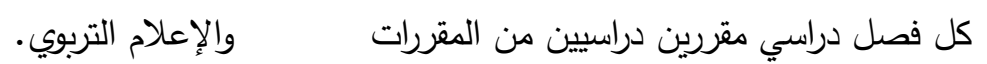

التخصصية الإجبارية، ومن الملاحظ علي لا توجد مادة لغة أجنبية أو ترجمة إعلامية

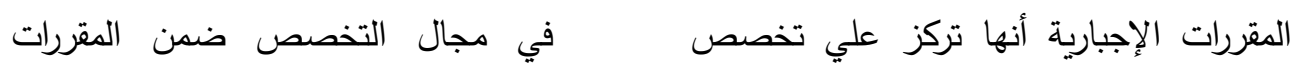

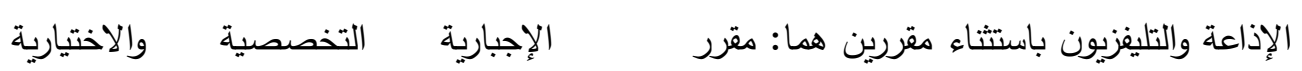

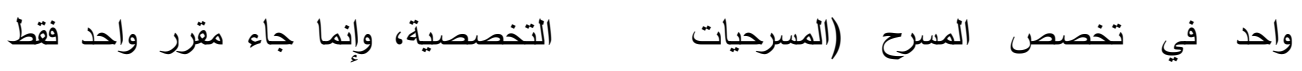

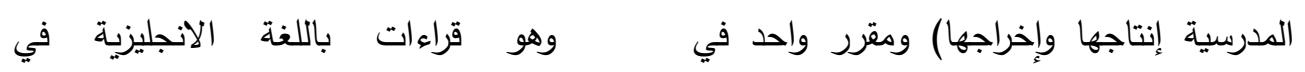

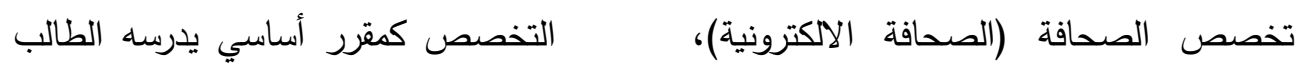

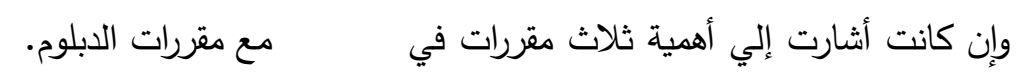

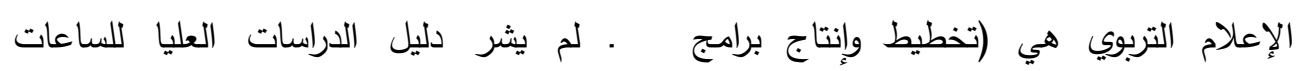
الإذاعة الددرسية، المسرحيات المدرسية إنتاجها التطبيقية للمقررات الدراسية ودرجة الثفئي والتحريري وأعمال السنة وزمن الامتحان وإخراجها، التليفزيون التعليمي). المقرر لها، ولكن عرف الساعة المعتمدة علي أنها تعادل محاضرة نظرية مدتها ساعة واحدة في الأسبوع أو درس تطبيقي تعادي

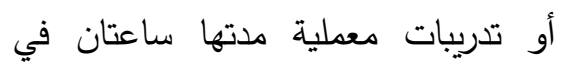

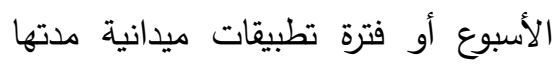

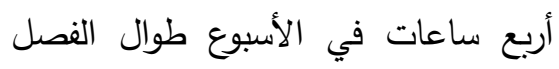

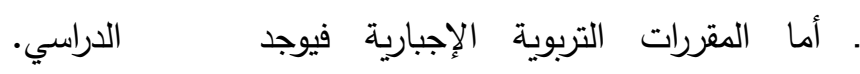
مقرر (نظريات الاتصال)، هذا المقرر من بالإضافة لدراسة هذه المقررات يدرس الطالب ثلاث مقررات أساسية مع دراسته لمقررات

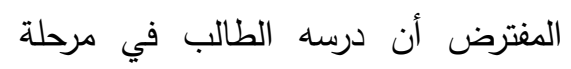

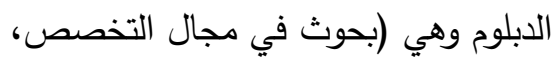

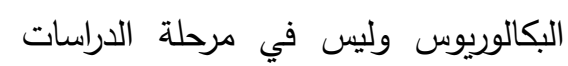

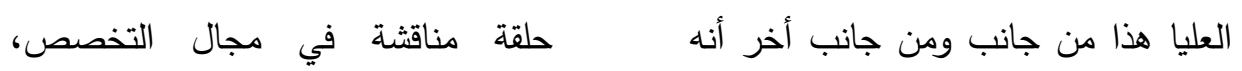

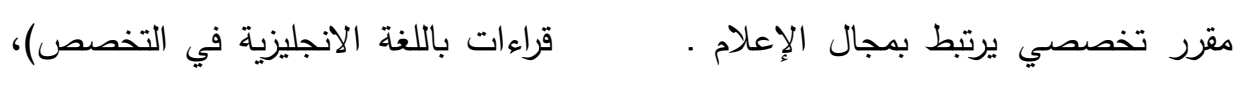

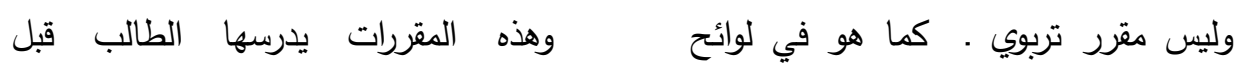




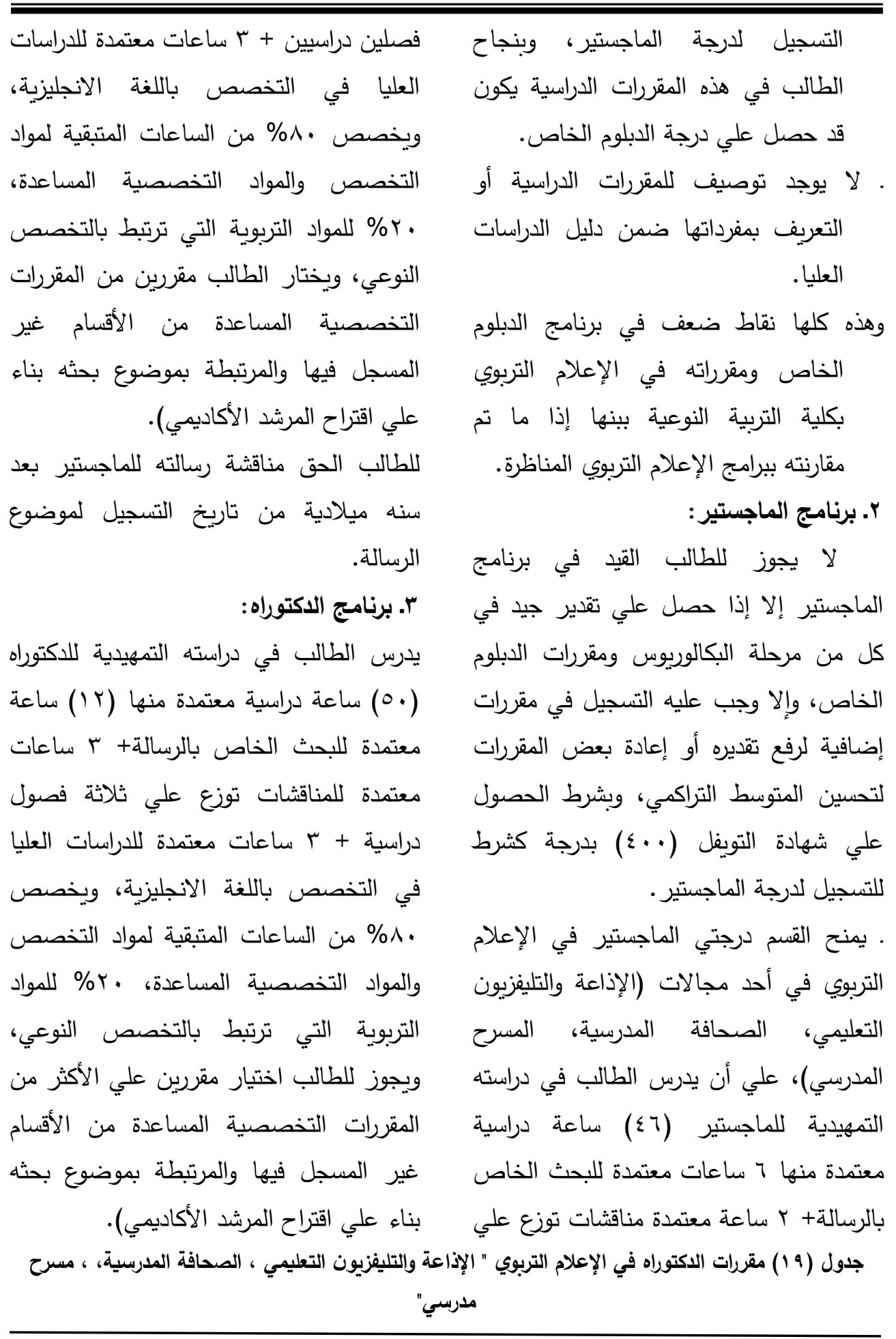




\begin{tabular}{|c|c|c|c|}
\hline المقررات التربوية الإجبارية & م & المقررات التخصصية الإجبارية & s \\
\hline بناء أدوات القياس في التخصص & 1 & إذاعة مدرسية (متقدمة) & 1 \\
\hline إحصاء متقدم & $r$ & تخطيط إذاعي وتليفزيوني (متقدم) & $r$ \\
\hline \multicolumn{2}{|c|}{ مقرلت أساسية للتسجيل للاكتوركاه } & صحافة مدرسية (متقدمة) & $r$ \\
\hline قراءات باللغة الانجليزية في التخصص & 1 & حركة الكاميرا وجمال الصورة & $\varepsilon$ \\
\hline حلقة مناقثة في مجال التخصص & $r$ & إخراج مسرحي (متقدم) & $\circ$ \\
\hline بحوث في مجال التخصص & $r$ & استماع وتذوق موسيقي & 7 \\
\hline \multicolumn{4}{|c|}{ المقررات التخصصية الاختيارية } \\
\hline تذوق الموسيقي ونقدها & 0 & مسرحة المناهج التعليمية & 1 \\
\hline تصميم وتنفيذ الملابس ومكملاتها & 7 & الصحافة الاكترونية وإخراجها (متقدم) & $r$ \\
\hline \multirow[t]{2}{*}{ حاسب آلي في مجال التخصص } & \multirow[t]{2}{*}{$\mathrm{v}$} & أدب عالمي مقارن للطفل & $r$ \\
\hline & & تذوق الفنون التشكيلية & $\varepsilon$ \\
\hline
\end{tabular}

من هذا الجدول يتضح وجود تثابه .المقررات التخصصية الاختيارية السبعة وتكرار إلي حد كبير في مسميات بعض ليمنت أربعة مقررات عامة ليست المقررات مع مقررات الماجستير التخصصية مقررات تخصصية دقيقة (تذوق الفنون والاختيارية. التشكيلية، تذوق الموسيقي ونقدها، تصميم

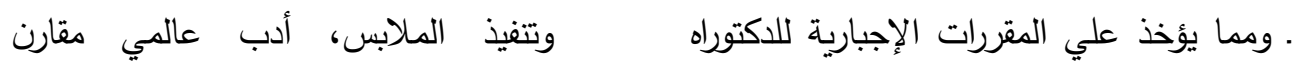

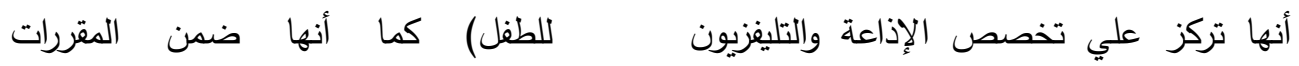
باستثاء مقررين: مقرر واحد في تخصص التخصصية الاختيارية في الماجستير المسرح (إخراج مسرحي متقدم) ، ومقرر واحد أما المقررات الثلاثة الأساسية والتي يدرسها الطالب مع مقررات الدكتوراه (بحوث في في تخصص الصحافة (صحافة مدرسية مجال التخصص، حلقة مناقشة في مجال متقدمة) ومقرر واحد عام (استماع وتذوق موسيقي) وهو مقرر يتشابه إلي حد كبير مع مقرر (تذوق الموسيقي ونقدها) كواحد من المقررات التخصصية الاختيارية للدكتوراه. الثلاثة الأساسية للماجستير، وهذه نقاط ضعف تحتاج إلى تحسين. - بعض المقررات الإجباريـة التخصصـية مـن المفترض أن درسـها الطالب في برنـامج ويشترط للتسجيل لدرجة الدكتوراه نجاح الطالب في هذه المقررات والحصول علي البكـالوريوس أو برنـامج الماجستير وليس تقدير جيد وإلا وجب علي الطالب مقـررات لبرنــامج الـدكتوراه (كالصــحافة التسجيل في مقررات إضافية أو إعادة المدرسـية والإذاعـة المدرسـية، الصــحافة بعض المقررات لتحسين المتوسط، واجتياز الالكترونية). 


\begin{tabular}{|c|c|}
\hline 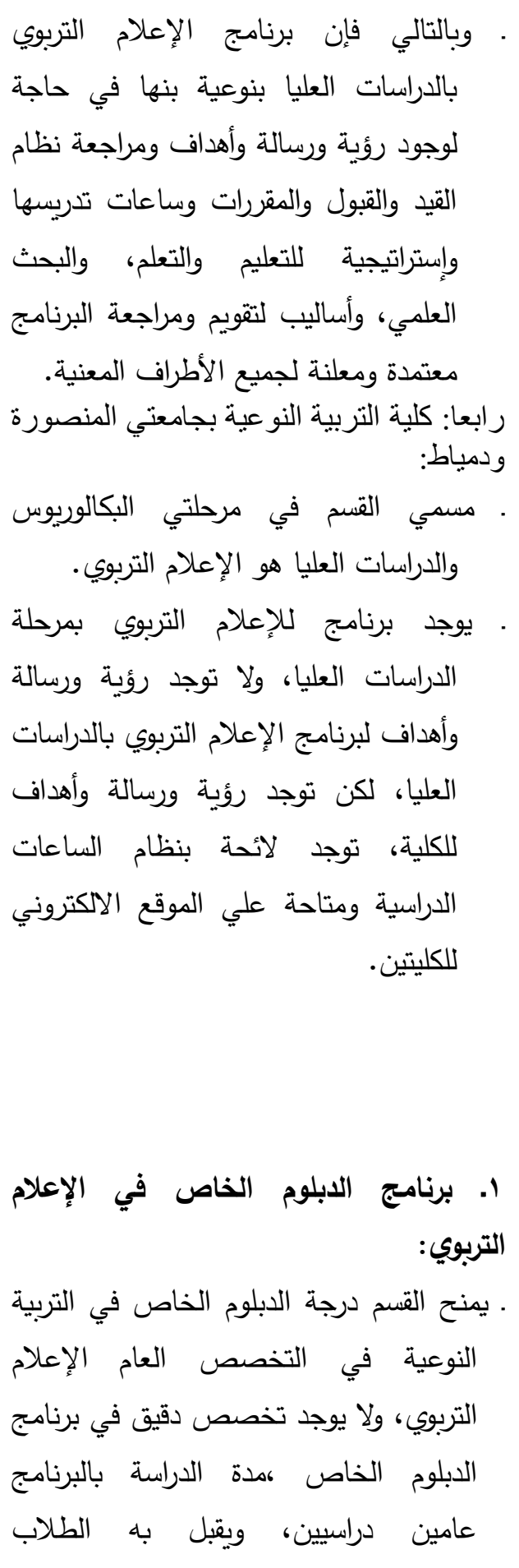 & 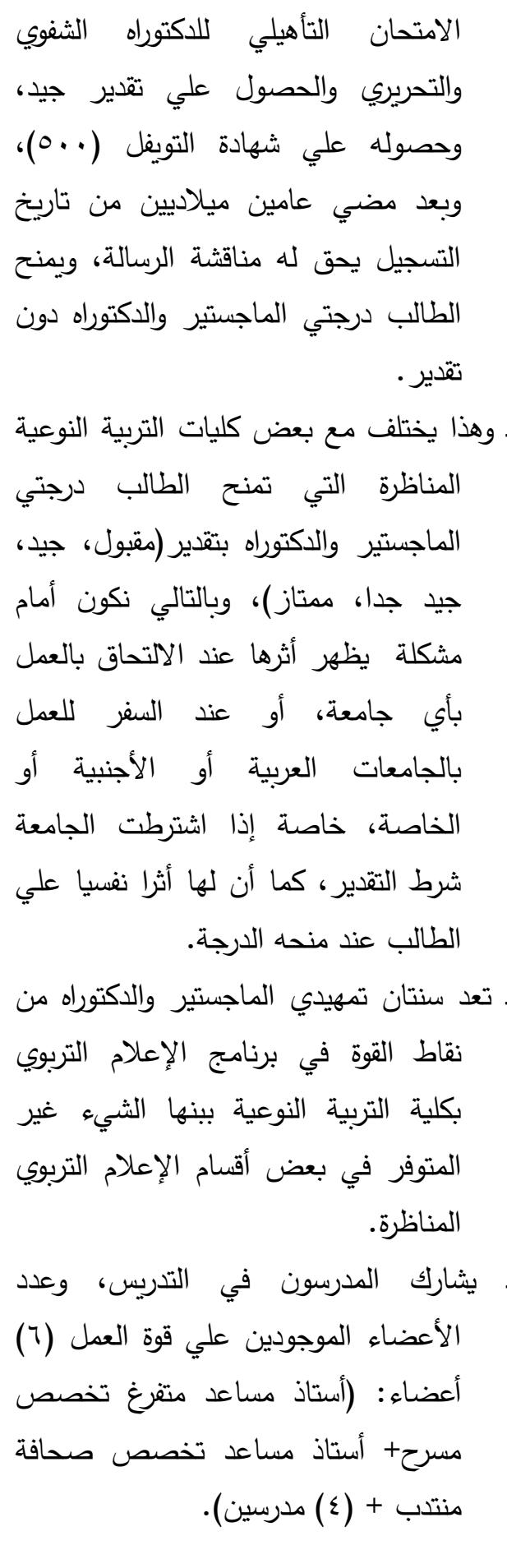 \\
\hline
\end{tabular}


تحريري وشفوي في نصوص في مجال التخصص بلغة أجنبية كثرط للقيد بالدبلوم

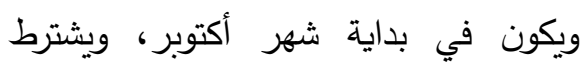

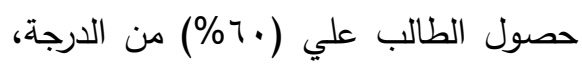
تبدأ الدراسة في شهر أكتوبر وتتتهي في مايو بعقد امتحان في نهاية العام، ويسمح للطالب بالإعادة مرة واحدة فقط.

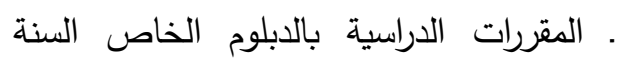

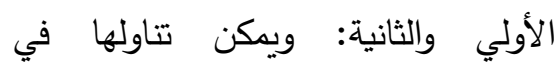

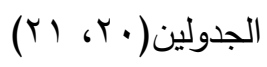

الحاصلين على درجة البكالوريوس في مالن

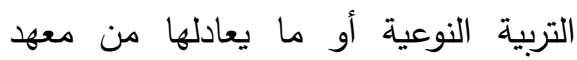
علمي معترف باه من المجلس الأعلى للجامعات بشرط الحصول على تقدير جيد على الأقل في الدرجة الجامعية الأولى . تم تعديله ويسمح للطلاب الحاصلين علي تقدير مقبول . ، ولا يسمح لغير خريجي قسم

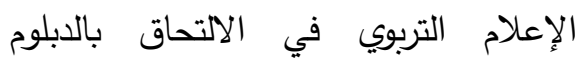
الخاص، ويعفى الطلاب الوافدون من شرط الحصول على تقدير جيد، ويعقد امتحان

جدول (·r) الساعات التدريسية لبرنامج الدبلوم الخاص في الإعلام التربوي السنة الأولي : نظام العام الدراسي

\begin{tabular}{|c|c|c|c|c|c|c|}
\hline \multicolumn{4}{|c|}{ النهاية العظمي للارجات } & \multirow{2}{*}{ الساعات } & \multirow[t]{2}{*}{ 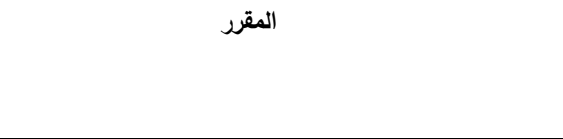 } & \multirow[t]{2}{*}{ b } \\
\hline 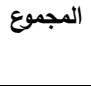 & عملي & أعمال سنة & تحريري & & & \\
\hline 50 & - & 10 & 40 & 2 & *دراسات في علم النفس (1) & 1 \\
\hline 50 & - & 10 & 40 & 2 & * دراسات في التربية (1) & r \\
\hline 50 & - & 10 & 40 & 2 & * دراسات في المناهج وتكنولوجيا التعليم وطرق التدريس (1) & $r$ \\
\hline 100 & r. & $r \cdot$ & 60 & 4 & إحصاء وحاسب آلي & $\varepsilon$ \\
\hline 100 & r. & $r \cdot$ & 60 & 4 & المسرح التربوي & $\bullet$ \\
\hline 100 & - & 20 & 80 & 4 & دراسات في علوم الصحافة & 7 \\
\hline 100 & - & 20 & 80 & 4 & دراسات في الإذاعة والتلفزيون التعليمي & $v$ \\
\hline 100 & - & 20 & 80 & 4 & 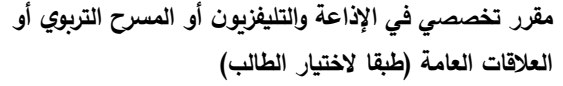 & $\wedge$ \\
\hline 650 & - & - & - & 26 & الإجمالي & \\
\hline
\end{tabular}

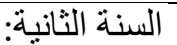

جدول ( آY) الساعات التتريسية لبرنامج الابلوم الخاص في الإعلام التربوي السنة الثانية : نظام العام الدراسي

\begin{tabular}{|c|c|c|c|c|c|c|}
\hline \multicolumn{4}{|c|}{ النهاية العظمي للارجات } & \multirow{2}{*}{ الساعات } & \multirow[t]{2}{*}{ 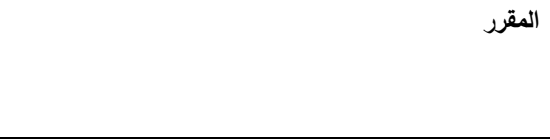 } & p \\
\hline 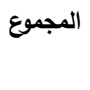 & 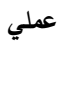 & أعمال سنة & 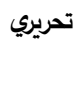 & & & \\
\hline 50 & - & 10 & 40 & 2 & " دراسات في علم النفس(؟) & 1 \\
\hline $\mathbf{5 0}$ & - & 10 & 40 & 2 & (ץ) دراسات في التربية(؟) & r \\
\hline 50 & - & 10 & 40 & 2 & *دراسات في المناهج وطرق التدريس وتكنولوجيا التعليم (؟)" & $r$ \\
\hline 100 & - & 20 & 80 & 4 & طرق البحث العلمي & $\varepsilon$ \\
\hline
\end{tabular}




\begin{tabular}{|c|c|c|c|c|c|c|}
\hline 100 & - & 40 & 60 & 4 & حلقات مناقثة & 0 \\
\hline 100 & $r$. & $r$. & 60 & 4 & مسرحة المناهج & 7 \\
\hline 100 & 20 & 20 & 60 & 4 & نظريات الاتصال & $v$ \\
\hline 100 & - & 20 & 80 & 4 & مقرر تخصصي في الإذاعة والتلفزيون أو المسرح التربوي أو العلاقات & $\wedge$ \\
\hline 650 & - & - & & 26 & الإجمالي & \\
\hline
\end{tabular}

وبتحليل المقررات الدراسية بلائحة الكلية (ع) ساعات في مقرر طرق البحث العلمي،

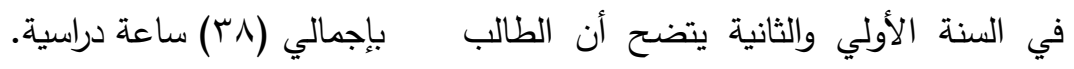

وبالتالي يكون إجمالي ساعات المقرات سداتهات يدرس في السنة الدراسية الأولي (16) ساعة والية

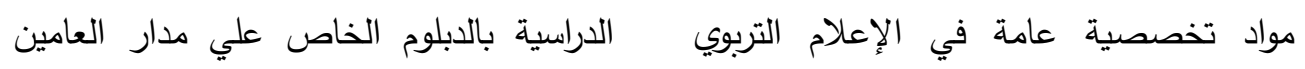

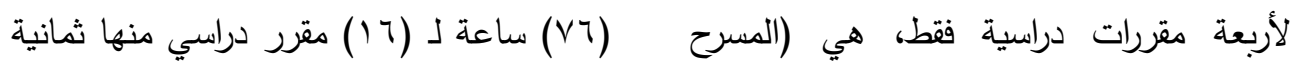

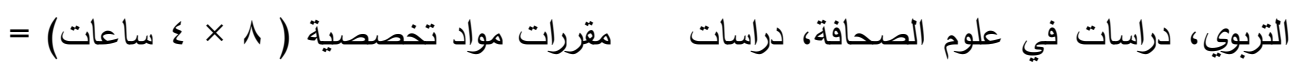

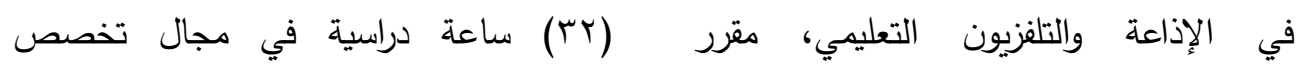

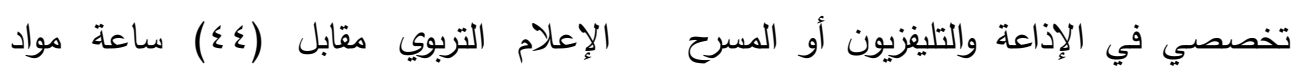
التربوي أو العلاقات العامة (طبقا لاختيار تربوية. من الملاحظ أيضا أنه يوجد مقرر واحد

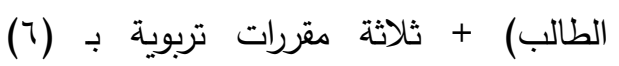

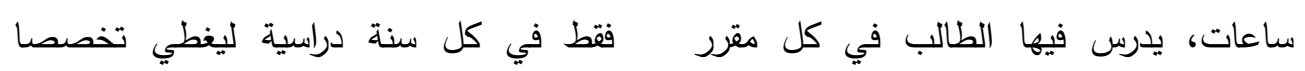

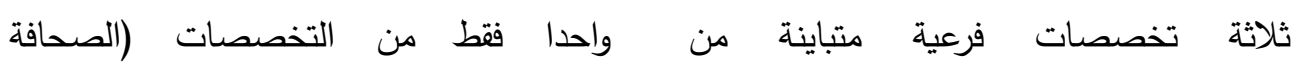
تخصصات الأقسام الأكاديمية التي تتنمي إليها المدرسية، الإذاعة والتليفزيون التعليمي، المسرح

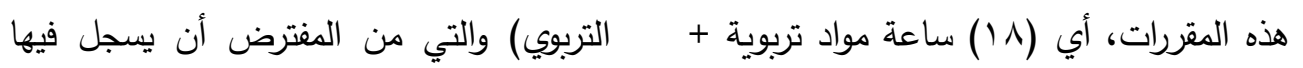

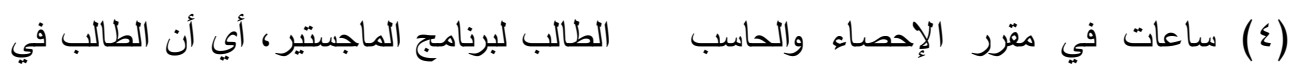

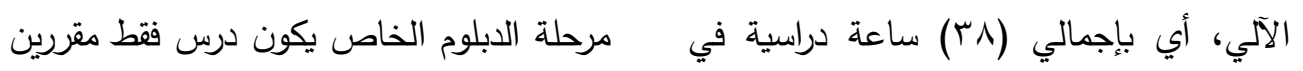

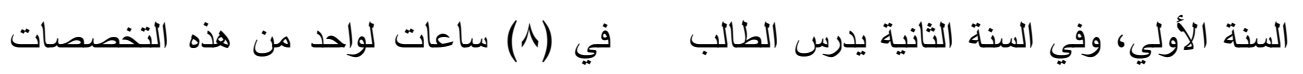

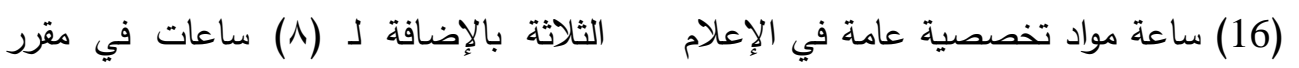
التربوي لأربعة مقررات دراسية فقط (حلقات تخصي في في الإذاعة والتلفيزيون أو المسرح

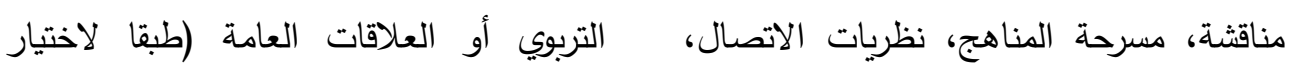

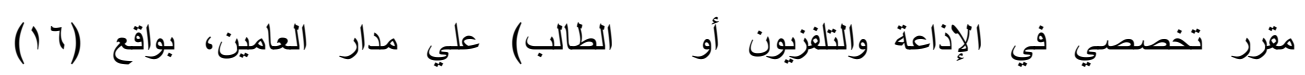

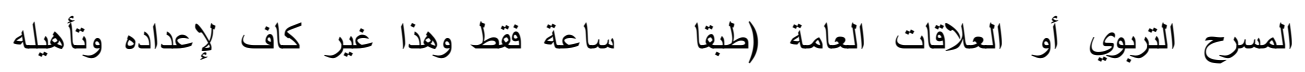

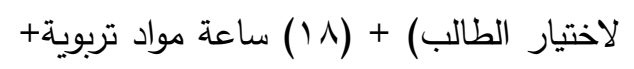




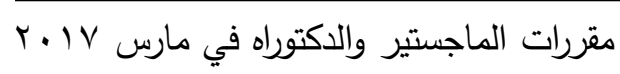

للتسجيل لدرجة الماجستير في الإعلام التربوي في أي من التخصصات الثلاث.

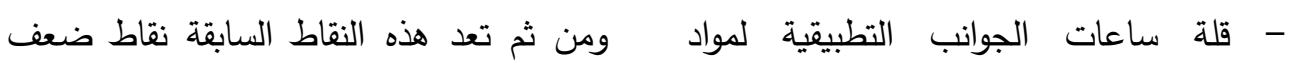
التخصص، فلم يوجد سوي مقرر المسرح تحتاج إلي تحسين وإعادة النظر في مقررات

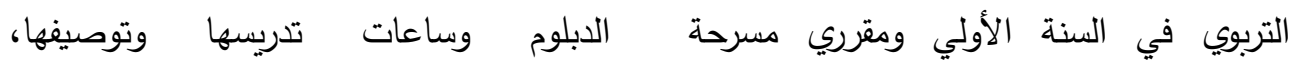

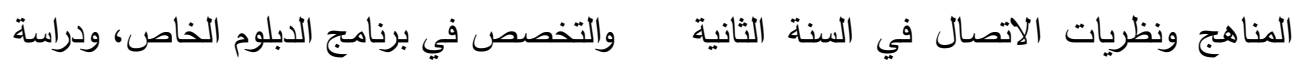
بواقع (7) ساعات تطبيقية علي مدار العامين مقرر في اللغة الانجليزية في التخصص.

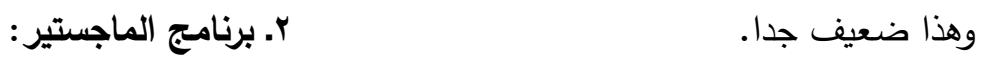
يمنح القسم درجة الماجستير في الإعلام التربوي في أحد تخصصات الإعلام التربوي - عدم وجود مقرر في اللغة الانجليزية في مدا.

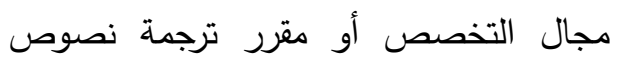
الثثلاثة (الصحافة المدرسية، الإذاعة والتليفزيون التعليمي، المسرح التربوي) ويشترط قيد الطالب المبات

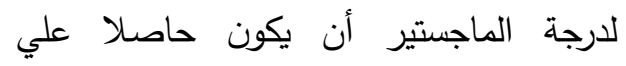
الابلوم الخاص في الإعلام التربوي من كلية

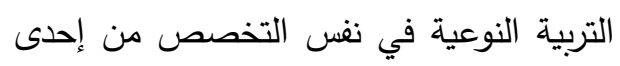

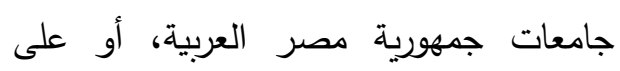

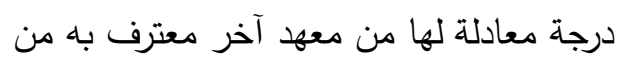

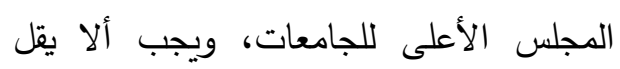
تقديره العام عن (جيد)، وألا يكون قد مضي وليدي علي حصوله أكثر من ثلاث سنوات، وقد تم إلغاء هذا الثرط الأخير . • يدرس الطالب بعد قيده لارجة الماجستير ثلاثة مقررات : (الإحصـاء المتقدم وتطبيقات الحاسب الآلي في مجال التخصص، مقررين في مجال التخصص أحدها بلغة أجنبية)، ويؤدى الطالب في كل منها امتحانًا لمدة ثلاث إعلامية في مجال التخصص علي مدار العامين. - غلبة المقررات التربوية علي المقررات التخصصية في الدبلوم الخاص، خاصة وأن

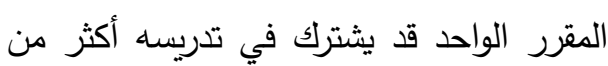
عضو هيئة تدري، مما يفرض علي الطلاب

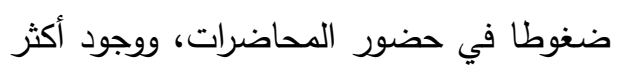
من كتاب مما يشعر الطلاب بالتثتت، كما في كثفت عنه مقابلات الباحث مع طلاب الدبلوم الخاص الفرقة الأولي والثانية.

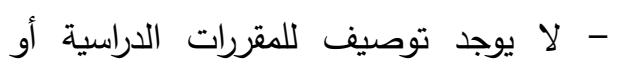
تعريف بمفرداتها، ومن ثم يترك الأمر لعضو لأورائ هيئة التدريس في اختيار موضوعات المقرر

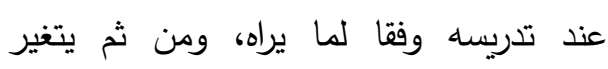
المحتوي التدريسي بتغير عضو هيئة التدريس،

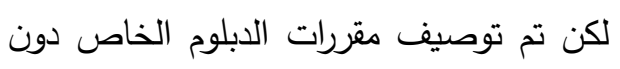

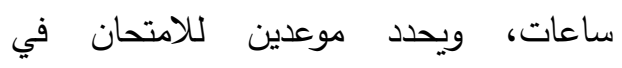


تاريخ القيد، ويحدد موعدين للامتحان في كل عام ( أكتوبر، أبريل ) ولا يجوز تشكيل لجنة

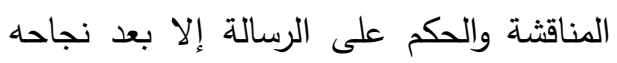
في هذه المقررات، وحضور قاعات البحث في

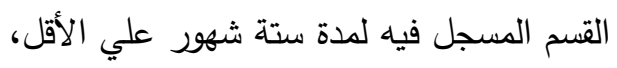
وحصوله علي شهادة التويفل ( •0؛ ) درجة. . لا يوجد توصيف للمقررات الدراسية ببرنامجي

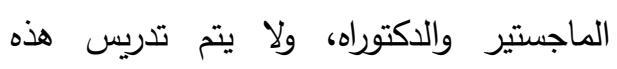
المقررات أسبوعيا، بل يقوم أستاذ المقرر

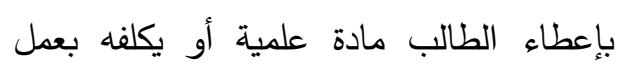

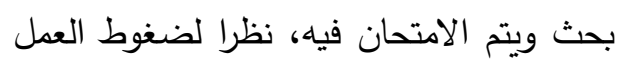
التي يتعرض لها أعضاء هيئة التدريس.

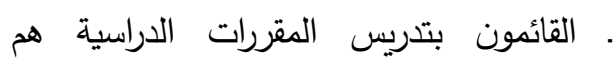

الأساتذة والأساتذة المساعدون وعددهم (0) المقرن

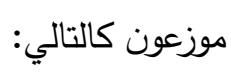

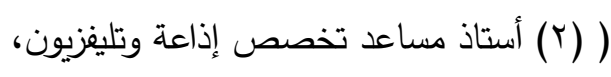
أستاذ مساعد

(1) مسرح' (1)

صحافة)، ولا يشارك المدرسون في التدريس،

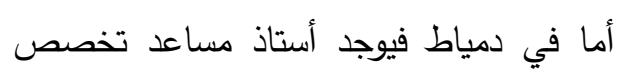
إذاعة وتليفزيون ويشارك المدرسون في في في

$$
\text { التدريس. - اعنة }
$$

• وبالتالي فإن برنامج الإعلام التربوي بنوعية

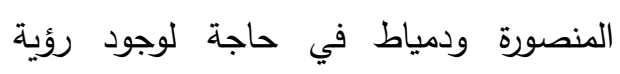
ورسالة وأهداف كما يحتاج إلي تحسين المقررات الدراسية وساعات تدريسها مع وجود إستراتيجية للتعليم والتعلم، وإستراتيجية للبحث
(أكتوبر، أبريل)، ولا يجوز تثكيل لجنة

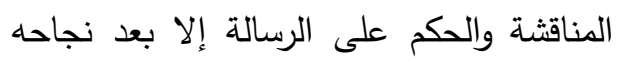

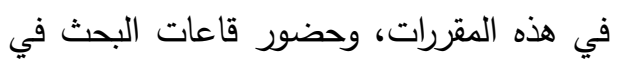

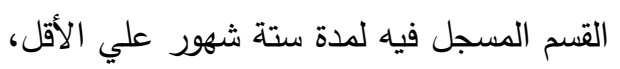
وحصوله علي شهادة التويفل ( · . ؟) درجة.

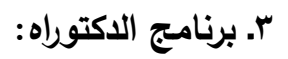
يمنح القسم درجة الدكتوراه في ثلاث تخصصات (الصحافة المدرسية، الإذاعة والتليفزيون التعليمي، المسرح التربوي)، ويتحدد الخديهات التهديه تخصص الطالب في برنامجي الماجستير والدكتوراه وفقا لاختياره موضوع رسالته الذي

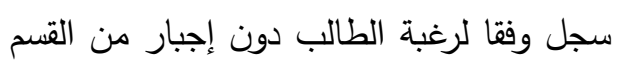
ـ يثترط قيد الطالب لدرجة الدكتوراه أن يكون حاصلا على درجة الماجستير في التربية

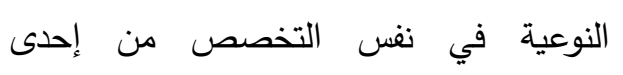

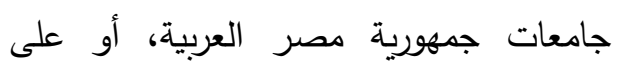

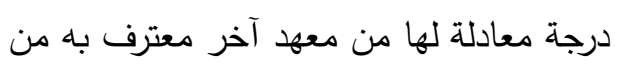

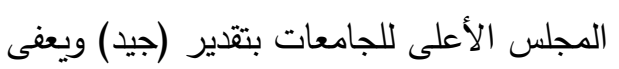
الطلاب الوافدون من هذا الشرط. ـ يدرس الطالب بعد قيده لبرنامج الدكتوراه ثلاثة

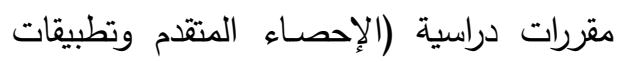
الحاسب الآلي في مجال التخصص، مقررين في مجال التخصص أحدهما بلغة أجنبية)،

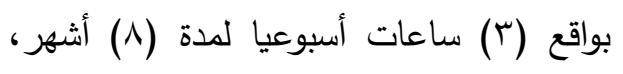
ويؤدى الطالب في كل منها امتحانًا لمدة ثلاث

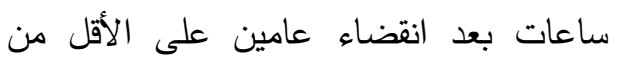


• يشترط قبول وقيد الطالب بالدبلوم الخاص: أن يكون حاصلا علي درجة البكالوريوس أو الليسانس في مجال التخصص من إحدى الجامعات المصرية أو درجة معادلة لها من لهن لهن الحئ معهد علمي معترف بتقدير جيد.

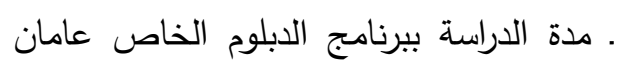
جامعيان، أي ثلاثين أسبوعا يتخللها أجازة نصف العام وتبدأ الدراسة في الأسبوع الأول الجائ التبوعان من شهر نوفمبر من كل عام.

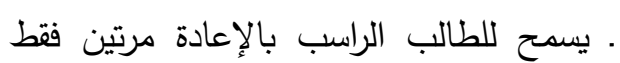

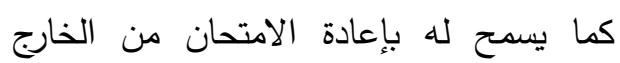

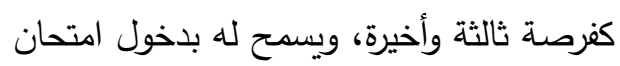
الدور الثاني في مقررين علي الأكثر قبل بدء لداء

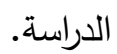

أ. المقررات الدراسية بالابلوم الخاص: السنة

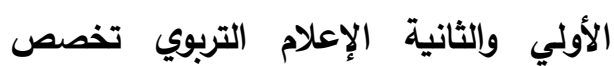

العلمي، وأساليب لتقويم ومراجعة البرنامج معتمدة ومعلنة لجميع الأطراف المعنية. خامسا: كلية التربية النو عية جامعة طنطا:

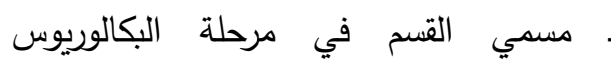
والدراسات العليا هو قسم الإعلام التربوي. ـ يوجد برنامج دراسات عليا بالقسم وتوجد رؤية

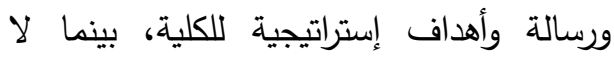
توجد رؤية ورسالة وأهداف معتمدة لبرنامج الإعلام التربوي، وتوجد لائحة بنظام الساعات الدراسية، ويوجد دليل لطلاب الدراسات العليا.

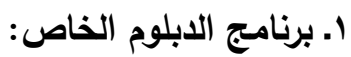

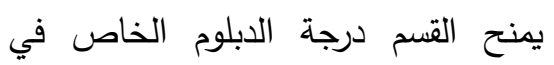
التربية النوعية في الإعلام التربوي في خمس لابوم تخصصات (صحافة، إذاعة، تليفزيون، علاقات عامة وإعلان)، وكذلك الدبلوم الخاص في المسرح (فنون المسرح، التذوق المسرحي).

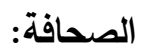

جدول (Y Y) الساعات التدريسية للابلوم الخاص في الإعلام التربوي تخصص(صحافة) السنة الأولي

\begin{tabular}{|c|c|c|c|c|c|c|c|c|c|}
\hline \multirow{2}{*}{ التحتحان } & \multicolumn{3}{|c|}{ 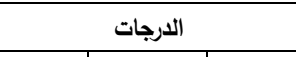 } & \multirow{2}{*}{ سنة أعمال } & \multicolumn{3}{|c|}{ الساعات الأسبوعية } & \multirow[t]{2}{*}{ المقررات الدراسية } & \multirow[t]{2}{*}{ s } \\
\hline & 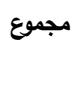 & 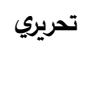 & تطبيقي & & 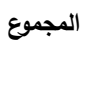 & تطبيقي & نظري & & \\
\hline$r$ & $1 \ldots$ & $\wedge$. & - & $r$. & $r$ & - & $r$ & موضوع خاص في التحرير الصحفي & 1 \\
\hline$r$ & $1 \ldots$ & $\wedge$. & - & $r$. & $r$ & - & $r$ & موضوع خاص في الإخراج الصحفي & $r$ \\
\hline$r$ & $1 \ldots$ & $\wedge$. & - & $r \cdot$ & $r$ & - & $r$ & الاتصال وقضايا المجتمع & $r$ \\
\hline$r$ & $1 \ldots$ & $\wedge$. & - & $r \cdot$ & $r$ & - & $r$ & مادة إعلامية بلغة أجنبية (1) & $\varepsilon$ \\
\hline$r$ & $1 \ldots$ & $\wedge$. & - & r. & $r$ & - & $r$ & مناهج بحث وكتابة بحث متخصص (1) & 0 \\
\hline$r$ & $1 \ldots$ & $\wedge$. & - & r. & $r$ & - & $r$ & الإحصاء وبحوث العمليات (1) & 7 \\
\hline- & 4. & - & - & - & Ir & - & Ir & المجموع & \\
\hline
\end{tabular}

السنة الثانية تخصص صحافة:

جدول (Yr) الساعات التدريسية لللبلوم الخاص في الإعلام التربوي تخصص (صحافة) السنة الأولي

\begin{tabular}{|c|c|c|c|c|c|}
\hline 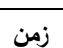 & الدرجات & أعمال & الساعات الأسبوعية & المقررات الدراسية & 5 \\
\hline
\end{tabular}




\begin{tabular}{|c|c|c|c|c|c|c|c|c|c|}
\hline التحريري & 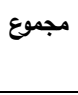 & 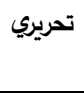 & تطبيقي & 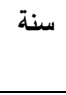 & 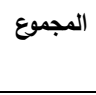 & تطبيقي & نظري & & \\
\hline$r$ & $1 \ldots$ & $\wedge$. & - & r. & $r$ & - & $r$ & الصحافة الاكترونية & 1 \\
\hline$r$ & $1 \cdots$ & $\wedge$. & - & r. & $r$ & - & $r$ & موضوع خاص في الإعلان الصحفي & $r$ \\
\hline$r$ & $1 \ldots$ & $\wedge$. & - & r. & r & - & $r$ & نظريات الاتصال ومداخله & $r$ \\
\hline$r$ & $1 \ldots$ & $\wedge$. & - & r. & $r$ & - & $r$ & مادة إعلامية بلغة أجنبية (ץ) & $\varepsilon$ \\
\hline$r$ & $1 \ldots$ & $\wedge$. & - & $r \cdot$ & $r$ & - & $r$ & مناهج بحث وكتابة بحث متخصص (r) & 0 \\
\hline$r$ & $1 \ldots$ & $\wedge$. & - & r. & $r$ & - & r & الإحصاء وبحوث العمليات (ץ) & 7 \\
\hline- & 7. & - & - & - & ir & - & ir & المجموع & \\
\hline
\end{tabular}

ب ـ تخصص الإذاعة السنة الأولي والثانية: جدول (؟ ب) الساعات التدريسية للدبلوم الخاص في الإعلام التربوي تخصص(إذاعة) السنة الأولي

\begin{tabular}{|c|c|c|c|c|c|c|c|c|c|}
\hline \multirow{2}{*}{ الامتحان } & \multicolumn{3}{|c|}{ 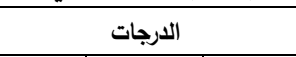 } & \multirow{2}{*}{ سنة } & \multicolumn{3}{|c|}{ الساعات الأسبوعية } & \multirow[t]{2}{*}{ المقرات الدراسية } & \multirow[t]{2}{*}{ s } \\
\hline & 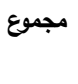 & 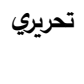 & تطبيقي & & 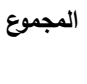 & تطبيقي & نظري & & \\
\hline$r$ & $1 \ldots$ & $\wedge$. & - & $r$. & r & - & r & موضوع خاص في الراديو & 1 \\
\hline$r$ & $1 \ldots$ & A. & - & r. & r & - & r & الثبكات الإذاعية الدولية & r \\
\hline$r$ & $1 \ldots$ & A. & - & r. & r & - & r & الاتصال وقضايا المجتمع & $r$ \\
\hline$r$ & $1 \ldots$ & $\wedge$. & - & $r$. & r & - & r & مادة إعلامية بلغة أجنبية (1) & $\varepsilon$ \\
\hline$r$ & $1 \ldots$ & A. & - & $r$. & r & - & r & مناهج بحث وكتابة بحث متخصص (1) & - \\
\hline$r$ & $1 \ldots$ & A. & - & r. & r & - & r & الإحصاء وبحوث العمليات (1) & 1 \\
\hline- & 7. & - & - & - & ir & - & ir & المجموع & \\
\hline
\end{tabular}

السنة الثانية تخصص إذاعة:

جدول (Y0) الساعات التدريسية للدبلوم الخاص في الإعلام التربوي تخصص(إذاعة) السنة الثانية

\begin{tabular}{|c|c|c|c|c|c|c|c|c|c|}
\hline \multirow{2}{*}{ الامتحان } & \multicolumn{3}{|c|}{ 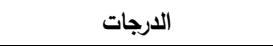 } & \multirow{2}{*}{ أعمال } & \multicolumn{3}{|c|}{ الساعات الأسبوعية } & \multirow[t]{2}{*}{ المقرات الدراسية } & \multirow[t]{2}{*}{ p } \\
\hline & 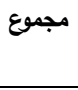 & 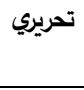 & تطبيقي & & 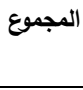 & تطبيقي & 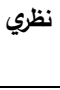 & & \\
\hline$r$ & $1 \ldots$ & $\wedge$. & - & r. & r & - & r & البرامج الثقافية & 1 \\
\hline$r$ & $1 \ldots$ & $\wedge$. & - & $r \cdot$ & r & - & r & موضوع خاص في الإعلان الإذاعي & r \\
\hline$r$ & $1 \ldots$ & A. & - & r. & r & - & r & نظريات الاتصال ومداخله & $r$ \\
\hline$r$ & $1 \ldots$ & A. & - & r. & r & - & r & مادة إعلامية بلغة أجنبية (ץ) & $\varepsilon$ \\
\hline$r$ & $1 \cdots$ & $\wedge$. & - & r. & r & - & $r$ & مناهج بحث وكتابة بحث متخصص (ץ) & $\bullet$ \\
\hline$r$ & $1 \cdots$ & $\wedge$. & - & $r \cdot$ & $r$ & - & $r$ & الإحصاء وبحوث العمليات (ץ) & 7 \\
\hline - & 7. & - & - & - & ir & - & ir & المجموع & \\
\hline
\end{tabular}

ج ـ تخصص التليفزيون السنة الأولي والثانية:

جدول (Yr) الساعات التدريسية للابلوم الخاص في الإعلام التربوي تخصص(تليفزيون) السنة الأولي

\begin{tabular}{|c|c|c|c|c|c|c|c|c|c|}
\hline \multirow{2}{*}{ الامتحان } & \multicolumn{3}{|c|}{ الارجات } & \multirow{2}{*}{ سنة } & \multicolumn{3}{|c|}{ الساعات الأسبوعية } & \multirow[t]{2}{*}{ المقررات الدراسية } & \multirow[t]{2}{*}{ r } \\
\hline & مجموع & تحريري & تطبيقي & & المجموع & تطبيقي & نظري & & \\
\hline
\end{tabular}




\begin{tabular}{|c|c|c|c|c|c|c|c|c|c|}
\hline \multicolumn{10}{|c|}{ 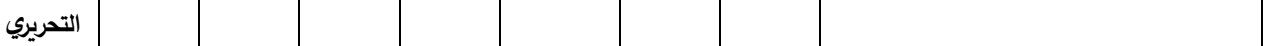 } \\
\hline r & $1 \ldots$ & $\wedge$. & - & r. & r & - & r & موضوع خاص في التليفزيون & 1 \\
\hline r & $1 \ldots$ & $\wedge$. & - & r. & r & - & r & الثبكات الفضائية للتليفزيون & r \\
\hline$r$ & $1 \ldots$ & $\wedge$. & - & $r$. & r & - & r & الاتصال وقضايا المجتمع & $r$ \\
\hline$r$ & $1 \ldots$ & $\wedge$. & - & r. & r & - & r & مادة إعلامية بلغة أجنبية (1) & $\varepsilon$ \\
\hline$r$ & $1 \ldots$ & $\wedge$. & - & r. & r & - & r & مناهج بحث وكتابة بحث متخصص (1) & • \\
\hline$r$ & $1 \ldots$ & $\wedge$. & - & r. & r & - & r & الإحصاء وبحوث العمليات(1) & 7 \\
\hline- & 7. & - & - & - & ir & - & Ir & المجموع & \\
\hline
\end{tabular}

السنة الثانية تخصص تليفزيون:

جدول (rV) الساعات التلريسية للابلوم الخاص في الإعلام التربوي تخصص(تليفزيون) السنة الثانية

\begin{tabular}{|c|c|c|c|c|c|c|c|c|c|}
\hline \multirow{2}{*}{ الامتحان } & \multicolumn{3}{|c|}{ 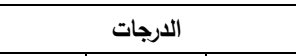 } & \multirow{2}{*}{ سنة أعمال } & \multicolumn{3}{|c|}{ الساعات الأسبوعية } & \multirow[t]{2}{*}{ المقرات الدراسية } & \multirow[t]{2}{*}{ b } \\
\hline & مجموع & 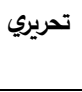 & تطبيقي & & 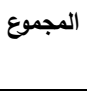 & تطبيقي & نظري & & \\
\hline$r$ & $1 \ldots$ & $\wedge$. & - & $r$. & r & - & r & البرامج الثقافية & 1 \\
\hline$r$ & $1 \ldots$ & $\wedge$. & - & $r$. & r & - & $r$ & الإعلان التليفزيوني & r \\
\hline$r$ & $1 \ldots$ & $\wedge$. & - & $r \cdot$ & r & - & r & نظريات الاتصال ومداخله & $r$ \\
\hline$r$ & $1 \ldots$ & $\Lambda$. & - & $r$. & $r$ & - & r & مادة إعلامية بلغة أجنبية (Y) & $\varepsilon$ \\
\hline$r$ & $1 \ldots$ & $\wedge$. & - & $r$. & r & - & $r$ & مناهج بحث وكتابة بحث متخصص (r) & • \\
\hline$r$ & $1 \ldots$ & $\wedge$. & - & $r$. & $r$ & - & r & الإحصاء وبحوث العمليات (ץ) & 7 \\
\hline- & 7. & - & - & - & Ir & - & ir & المجموع & \\
\hline
\end{tabular}

دـ ـ تخصص العلاقات العامة والإعلان السنة الأولي وإلثانية:

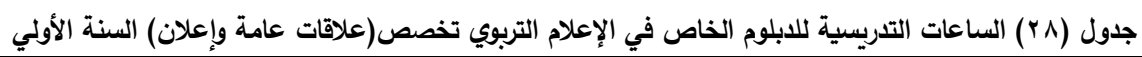

\begin{tabular}{|c|c|c|c|c|c|c|c|c|c|}
\hline \multirow{2}{*}{ الامتحان } & \multicolumn{3}{|c|}{ الدرجات } & \multirow{2}{*}{ سنة } & \multicolumn{3}{|c|}{ الساعات الأسبوعية } & \multirow[t]{2}{*}{ المقرات الدراسية } & \multirow[t]{2}{*}{ r } \\
\hline & 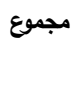 & تحريري & تطبيقي & & 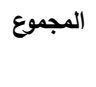 & تطبيقي & 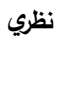 & & \\
\hline$r$ & $1 \ldots$ & $\Lambda$. & - & r. & r & - & r & موضوع خاص في العلاقات العامة & 1 \\
\hline$r$ & $1 \ldots$ & $\Lambda$. & - & r. & r & - & r & موضوع خاص في الإعلان & r \\
\hline r & $1 \ldots$ & $\wedge$. & - & r. & r & - & r & الاتصال وقضايا المجتمع & $r$ \\
\hline$r$ & $1 \ldots$ & $\Lambda$. & - & r. & $r$ & - & r & مادة إعلامية بلغة أجنبية (1) & $\varepsilon$ \\
\hline$r$ & $1 \ldots$ & $\wedge$. & - & r. & r & - & r & مناهج بحث وكتابة بحث متخصص (1) & 。 \\
\hline$r$ & $1 \ldots$ & $\wedge$. & - & r. & r & - & r & الإحصاء وبحوث العمليات (1) & 9 \\
\hline- & 9 & - & - & - & ir & - & ir & المجموع & \\
\hline
\end{tabular}

السنة الثانية تخصص علاقات عامة وإعلان:

جدول (ra) الساعات التتريسية للابلوم الخاص في الإعلام التربوي تخصص(علاقات عامة وإعلان) السنة الثانية

\begin{tabular}{|c|c|c|c|c|c|c|c|c|c|}
\hline زمن & & الارجات & & أعمال & & اعات الأس & & المقررات الدراسية & P \\
\hline التحريري & مجموع & تحريري & تطبيقي & سنة & المجموع & تطبيقي & نظري & & \\
\hline
\end{tabular}




\begin{tabular}{|c|c|c|c|c|c|c|c|c|c|}
\hline$r$ & $1 \ldots$ & $\wedge$. & - & r. & $r$ & - & $r$ & العلاقات العامة الدولية & 1 \\
\hline$r$ & $1 \ldots$ & $\wedge$. & - & r. & $r$ & - & $r$ & التسويق الاجتماعي & r \\
\hline$r$ & $1 \ldots$ & $\wedge$. & - & r. & $r$ & - & r & نظريات الاتصال ومداخله & $r$ \\
\hline$r$ & $1 \ldots$ & $\wedge$. & - & $r \cdot$ & r & - & r & مادة إعلامية بلغة أجنبية (ץ) & $\varepsilon$ \\
\hline$r$ & $1 \ldots$ & $\wedge$. & - & r. & r & - & r & مناهج بحث وكتابة بحث متخصص (ץ) & $\bullet$ \\
\hline$r$ & $1 \ldots$ & $\wedge$. & - & $r \cdot$ & $r$ & - & $r$ & الإحصاء وبحوث العمليات(ץ) & 9 \\
\hline- & 9. & - & - & - & ir & - & ir & المجموع & \\
\hline
\end{tabular}

حدد الدليل وجود اشتراطات خاصة بالدبلوم

الخاصة في فنون المسرح منها:

1. الدبلوم الخاصة في فنون المسرح:

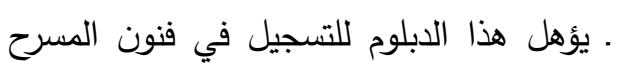
للحاصلين علي تقدير جيد علي الأقل.

• يلتزم كل طالب بتقديم مشروع عملي في كل تل سنة دراسية تحت إثراف أستاذ مادة

المشروع ويتم اعتماد المشروع بعد موافقة مجلس القسم وهذه المشروعات تكون

$$
\text { كالأتي : }
$$

. في نهاية السنة الأولي يلتزم الطالب بتقديم مشهد لعمل مسرحي من الأعمال العالمية

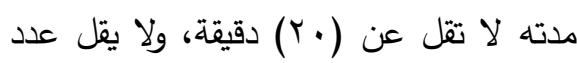
المشاركين في المشروع عن اثثين مع إظهار العمل بكل عناصره المسرحية. . في نهاية السنة الثانية يلتزم الطالب بتقديم مشهد لعمل معاصر أو تجريبي لفن المسرح

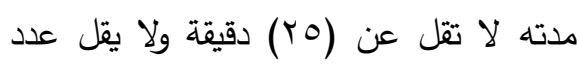
المشاركين عن ثلاثة مع إظهار العمل بكل

عناصره المسرحية. r ـ ـ الدبلوم الخاص في التذوق المسرحي:
من تحليل هذه الجداول يدرس الطالب

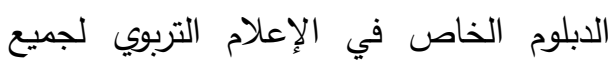
التخصصات الأربعة (الصحافة، الإذاعة، الإعلة التربية

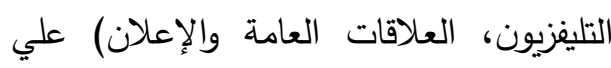
مدار عامين دراسيين في (Y Y) ساعة دراسية نظرية لستة مقررات دراسية دون وجود أي جوانب تطبيقية يتدرب عليها الطالب، ويؤدي دون ونيك فيها الامتحان في ثلاث ساعات، ولا يوجد توصيف أو تعريف للمقررات بدليل الطالب، وهذه نقاط ضعف تحتاج لمراجعة وتحسين. ـ اهتمت اللائحة بتدريس مقرر في اللغة فئة الأجنبية علي مدار سنتين في التخصصات

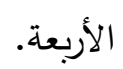
. نجد أن كلية التربية النوعية بطنطا هي الكلية الوحيدة التي فصلت تخصص الإذاعة عن تخصص التليفزيون ولكل منها سنتان دراسيتان في برنامج الدبلوم، وهي الكلية الوحيدة أيضا التي تمنح برنامج الدبلوم

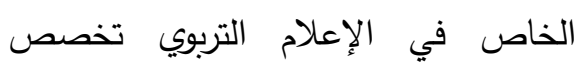
علاقات عامة وإعلان، وهذه من نقاط القوة في برنامج الإعلام التزبوي بطنطا. هـ ـ الابلوم الخاص في فنون المسرح: 
يمنح القصم الدبلوم الخاص دون وبذلك تعد كلية التربية النوعية طنطا هي

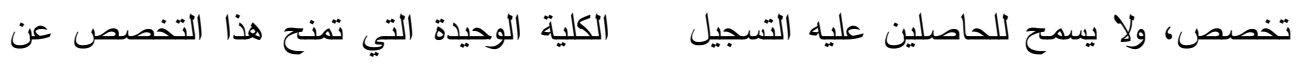

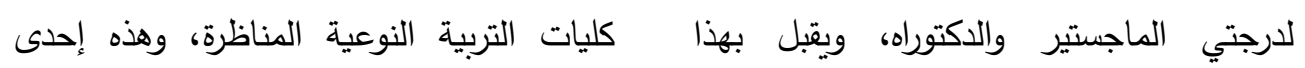

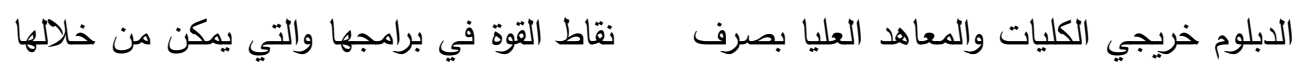
النظر عن طبيعة التخصص الذي تخرجوا منه تتمية موارد الكلية الذاتية. أو التقدير الحاصلين عليه، كما يقبل خريجي المقرات الدراسية للسنة الأولي والثانية: الكليات العسكرية، ويشترط اجتياز اختبارات القبول التي يحددها مجلس القسم والكلية،

\begin{tabular}{|c|c|c|c|c|c|c|c|c|c|c|}
\hline \multirow{2}{*}{ الامتحان } & \multicolumn{4}{|c|}{ الدرجات } & \multicolumn{4}{|c|}{ الساعات الأسبوعية } & \multirow{2}{*}{ المقررات اللاراسية } & \multirow[t]{2}{*}{ p } \\
\hline & 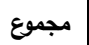 & تطبيقي & 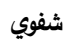 & تحريري & إشراف & تطبيقي & 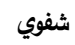 & 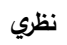 & & \\
\hline$r$ & o. & - & & o. & - & - & - & r & لغة انجليزية & 1 \\
\hline$r$ & o. & - & & o. & - & - & - & r & لغة عربية & r \\
\hline$r$ & o. & - & & o. & r & - & - & r & مذاهب مسرحية & $r$ \\
\hline r & $1 .$. & $r$. & r. & $\circ$. & r & r & r & r & دراما حركية واستعراضات (') & $\varepsilon$ \\
\hline$r$ & $\circ$. & - & 1. & $\varepsilon$ & $r$ & - & $r$ & $r$ & استماع وتنوق موسيقي (1) & $\circ$ \\
\hline$r$ & $\circ$. & $r$. & r. & - & r & - & - & r & حرفية وتذوق سينما ( ) & 4 \\
\hline تقديم بحث & ro & ro & - & - & - & $r$ & - & $r$ & مناهج بحث (ץ) & v \\
\hline$r$ & $\circ$. & - & - & $\circ$. & - & - & - & $r$ & تذوق فنون تثكيلية & $\wedge$ \\
\hline$r$ & 0. & - & - & 0. & - & - & - & $r$ & سوسيولوجيا الفلوكلور & 9 \\
\hline مشروع & 10. & o. & o. & o. & - & $\varepsilon$ & $\varepsilon$ & $\varepsilon$ & مشروع إعداد وتنفيذ & 1. \\
\hline- & ro & - & - & - & $\wedge$ & $\wedge$ & $\wedge$ & rr & 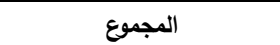 & \\
\hline
\end{tabular}

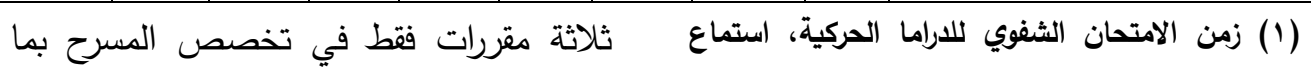

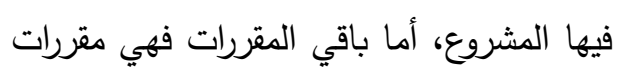

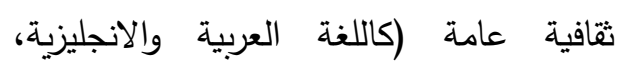
الاستماع والتذوق الموسيقي، حرفية وتذوق والنة

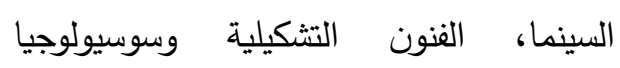
الفولكلور ).

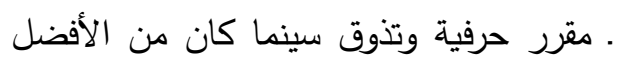
أن يدرس لطلاب الدبلوم تخصص تليفزيون

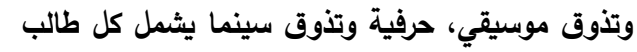
علي حدة. (ץ) مناهج بحث: يقدم الطالب بحثا في هذه المادة. ـ من هذا الجدول يتضح أن الطالب يدرس في دبلوم فنون المسرح في السنة الأولي († (؟)

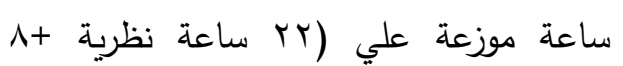

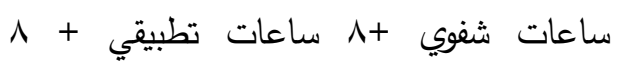
ساعات إثراف) لعشرة مقررات دراسية منها لطاعيات وليس لدبلوم فنون المسرح. 
السنة الثانية:

جدول ( آ⿱ الساعات التدربسية للدبلوم الخاص في فنون المسرح السنة الثانية

\begin{tabular}{|c|c|c|c|c|c|c|c|c|c|c|}
\hline \multirow{2}{*}{ الامتحان } & \multicolumn{4}{|c|}{ الدات } & \multicolumn{4}{|c|}{ الساعات الأسبوعية } & \multirow[t]{2}{*}{ المقررات الاراسية } & \multirow[t]{2}{*}{ p } \\
\hline & مجموع & تطبيقي & شفوي & تحريري & إشراف & تطبيقي & شفوي & نظري & & \\
\hline$r$ & o. & - & - & O. & - & - & - & $r$ & لغة انجليزية & 1 \\
\hline$r$ & $\circ$. & - & - & $\circ$. & - & - & - & $r$ & لغة عربية & $r$ \\
\hline$r$ & $1 \cdots$ & $r$. & $r$. & ○. & r & $\varepsilon$ & $\varepsilon$ & $r$ & إخراج مسرحي (1) & $r$ \\
\hline r & $1 \ldots$ & $r$. & $r$. & o. & r & r & r & r & 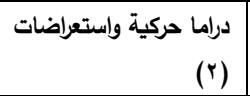 & $\varepsilon$ \\
\hline r & $\therefore$. & - & 1. & ؛. & r & r & - & r & 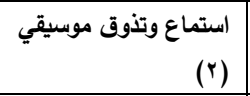 & 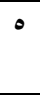 \\
\hline$r$ & ○. & r. & $r \cdot$ & - & - & - & - & r & حرفية وتذوق سينما (r) & 9 \\
\hline تقديم بحث & ๑. & - & - & O. & $r$ & r & - & r & تذوق فنون تشكيلية & $v$ \\
\hline مشروع & 10. & ○. & o. & ๑. & r & $\varepsilon$ & $\varepsilon$ & $\varepsilon$ & مشروع إعداد وتنفيذ & $\wedge$ \\
\hline$r$ & $\circ$. & - & - & $\circ$. & - & - & - & r & 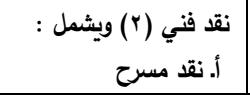 & 9 \\
\hline r & $\circ$. & - & - & $\circ$. & - & - & - & $r$ & نقد فن الباليه & \\
\hline r & $\circ$. & - & - & $\circ$. & - & - & - & r & النقد الموسيقي & \\
\hline r & ○. & - & - & 0. & - & - & - & r & قد الأوبرا والأوبريت & \\
\hline- & $\wedge \ldots$ & - & - & - & 1. & $1 \varepsilon$ & 1. & Yq & المجموع & \\
\hline
\end{tabular}

ساعات شفوي +ـ ا ساعة تطبيقي + 1. 1. سـاعات إشـراف ) لتسـعة مقررات دراسـية منهــا أربعـة مقـررات فقطـ في تخصـص المسـرح وهـي :(إخـراج مسـرحي، درامــا

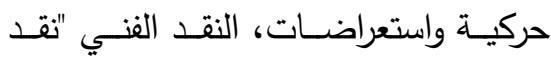
مسرح، مشروع)، أمـا باقي المقررات فهي مقـررات عامسـة ثقافيــة (كاللغـــة العربيـة والانجليزيـة، الاستماع والتذوق الموسيقي، حرفية وتذوق السينما، فنون تشكيلية).
. حدد دليل الطالب أن زمن الامتحان الثفوي لمـواد: (الإخـراج المسرحي، درامـا حركيـة واستعراضـات، اسـتماع وتذوق موسـيقي، حرفيـة وتـوق سـينما) يشـمل كـل طالب

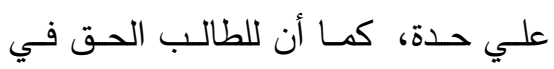
اختيار مادتين فقط من مقرر النقد الفني. ـ وبالتـالي يـدرس الطالب في دبلـوم فنـون المسـرح فـي السـنة الثانيـة (7هم) سـاعة موزعـة علـي (Y س سـاعة نظريــة +. 
الشرط تتفق فيه جميع كليات التربية النوعية فيما يخص برنامجي الماجستير والدكتوراه. ـ أما فيما يخص درجة الماجستير في المسرح

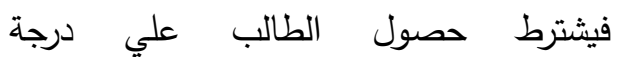
البكالوريوس في التربية النوعية أو ما يعادلها وأن يكون حاصلا علي جيد في دبلوم فنون المسرح ودرجة جيد جدا علي الأقل في مادة التخصص التي تحدد موضوع البحث ، كما جيد الته يجب أن تتضمن خطة الماجستير جانبا تطبيقيا عليا في التخصص،مع انتظام الطالب في حلقتي البحث (قضايا التربية

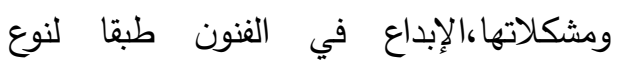
التخصص) بواقع ساعتين أسبوعيا لكل مادة، ويقدم الطالب بحثا في كل مادة يجيزه أستاذ

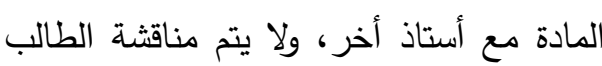

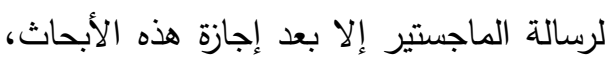
والحصول علي دورة الحاسب الآلي، ويمنح الطالب الدرجة بتقدير: ( ممتاز ، جيد جدا، دأ

$$
\text { جيد، مقبول). }
$$

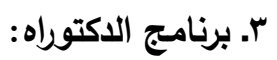
للحصول علي درجة الدكتوراه في بلاهي التخصصات السابقة لابد من الحصول علي

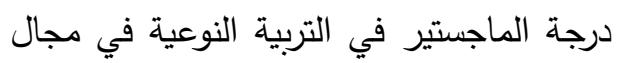
التخصص من إحدى كليات التربية النوعية أو

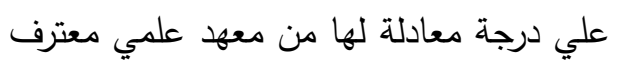
به بتقدير جيد، والحصول علي شهادة إتقان اللغة الانجليزية، والحصول علي سنة تمهيدية

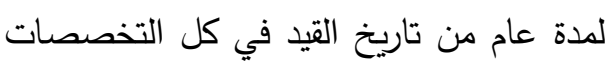

- المقررات العامـة والثقافية في السنة الثانية هي نفس مسميات مقررات السنة الأولي، وفي ذلك تكرار وتثابه كبير - اهتمت اللائحة بتدريس مقرر في اللغة ولتيه الأجنبية علي مدار السنتين الأولي والثانية في التخصصات الخمسة وهذا شيء جيد.

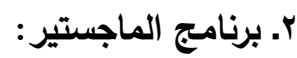
يمنح القسم ماجستير الإعلام التربوي في تخصصات (صحافة، إذاعة، تليفزيون، علاقات عامة وإعلان، المسرح)، بشرط لإنهات حصول الطالب علي الدبلوم الخاص في التربية النوعية في نفس التخصص وحصوله علي تقدير جيد في كل من البكالوريوس

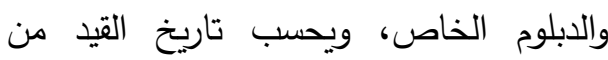

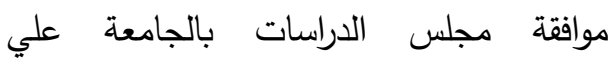
التسجيل، ويجوز مناقثة الطالب بعد مضي بلدي

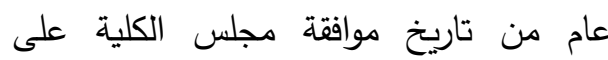
التسجيل، ويلغى قيد الطالب إذا لم يحصل ملتحل علي الدرجة خلال ثلاث سنوات من تاريخ القيد، إلا إذا وافق مجلس الكلية علي الإبقاء للتسجيل سنة أخري قابلة للتجديد مرتين باقتراح مسبب من المشرف بعد أخذ موافقة مجلس القسم، كما يشترط حصول الطالب علي شهادة إتقان اللغة الانجليزية، ونشر بحث من رسالة الماجستير في إحدى المجلات العلمية المحلية أو الدولية كشرط للحصول علي الدرجة، وهذا 
ما عدا درجة دكتوراه الفلسفة في مجال المسرح التذوق المسرحي) وهذه تعتبر نقاط قوة في التي لا تتطلب دراسة تمهيدية، ولكن يثترط برنامج الإعلام التربوي بطنطا.

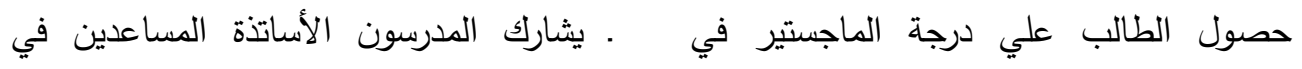
تخصص فنون المسرح بدرجة جيد علي الأقل تدريس المقررات النظرية والعملية، وعددهم

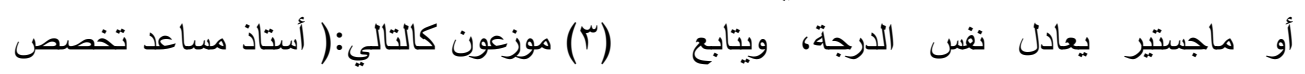

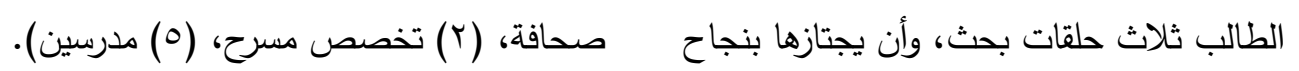

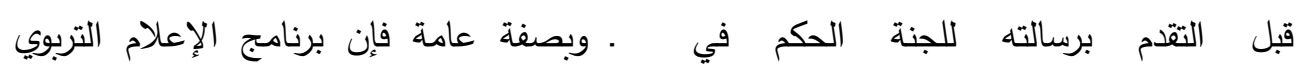

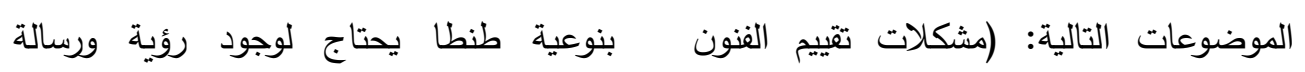

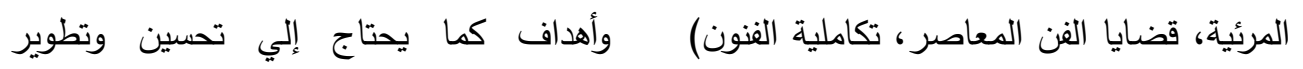
وذلك بواقع أربع ساعات أسبوعية لكل حلقة مقرراته وساعات تدريسها مع وجود إستراتيجية

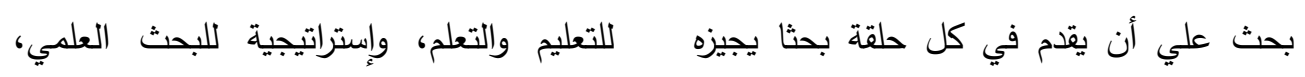

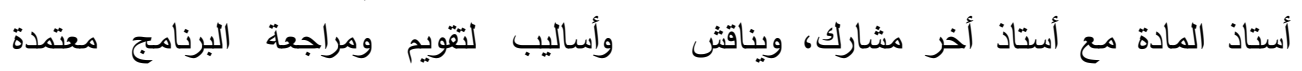
الطالب درجة الدكتوراه بعد مضي عامين علي ومعلنة لجميع الأطراف المعنية.

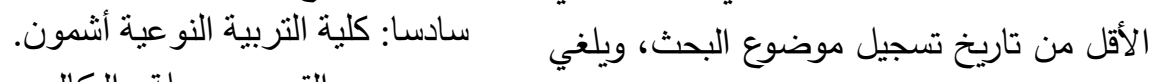

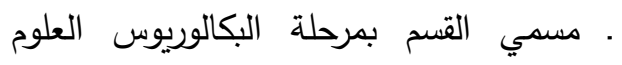
الاجتماعية والإعلام وفي مرحلة الدراسات لئل العليا الإعلام التربوي، وهنا يجب توحيد مسمي القسم بالمرحلتين.

• يوجد برنامج دراسات عليا بالقسم وتوجد رؤية

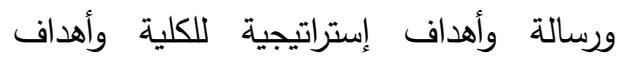
للاراسات العليا، بينما لا توجد رؤية ورسالة وأهداف معتمدة لبرنامج الإعلام التربوي، كما للإيات توجد لائحة بنظام الساعات الدراسية ومتاحة علي الموقع الالكتروني للكلية. ا. برنامج الدبلوم الخاص في الإعلام لإمية التربوي:

• يمنح القسم درجة الدبلوم الخاص في التربية النوعية في الإعلام التزبوي. تسجيل الطالب إذ لم يحصل علي الدرجة خلال خمس سنوات إلا إذا وافق مجلس الكلية علي الإبقاء للتسجيل سنة أخري قابلة للتجديد

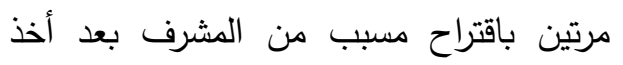

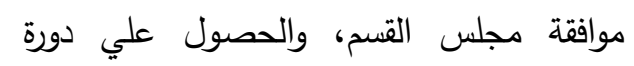
الحاسب الآلي، ويمنح الطالب الدرجة بتقدير: ( ممتاز، جيد جدا، جيد، مقبول).

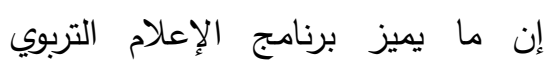

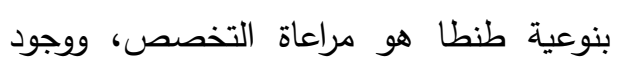
تخصص(علاقات عامة وإعلان) في برنامج

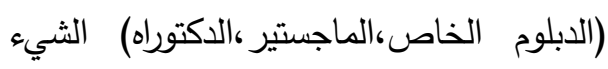
غير متاح لأقسام الإعلام التربوي المناظرة،

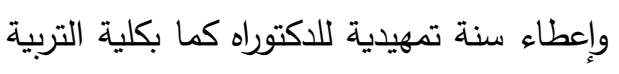
النوعية ببنها، بالإضافة لوجود دبلوم المسرح 
• يشترط قيد الطالب بالدبلوم الخاص: أن يكون يسمح للطلاب الحاصلين علي درجة مقبول

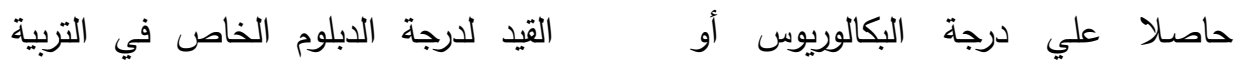
الليسانس في مجال التخصص من إحدى النوعية وهذا غير موجود بكليات التربية الجامعات المصرية أو درجة معادلة لهال النوعية الأخرى سوي نوعية الزقازيق.

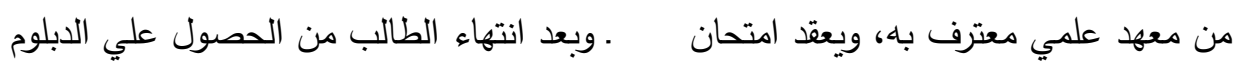

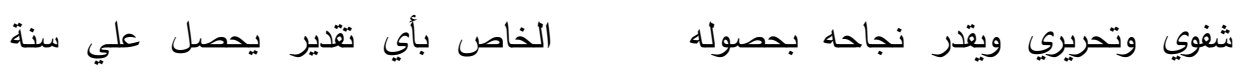

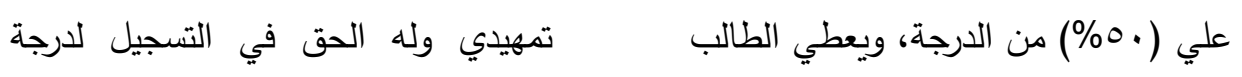

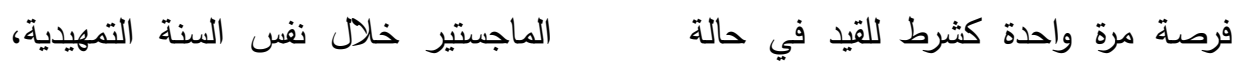

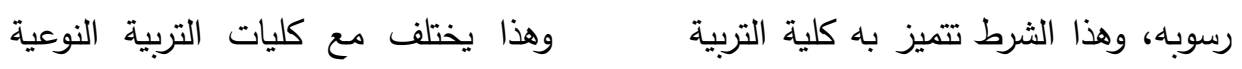

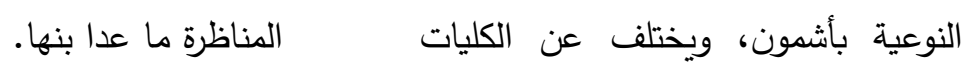

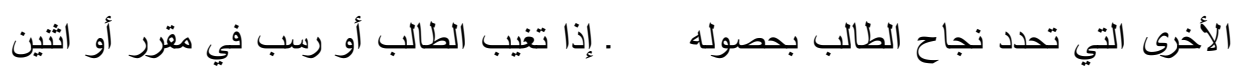

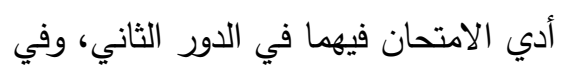
حالة رسوبه في أكثر من مقررين يعيد في الاني

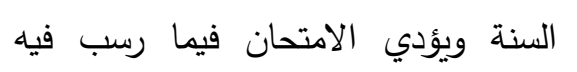
ويحسب تقديره (مقبول) وإذا رسب مردي الأبان

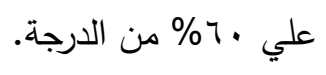
ـ مدة الدراسة ببرنامج الدبلوم الخاص علد عامين،

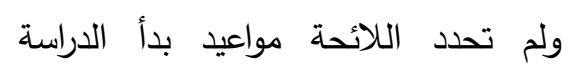
أخري ألغي قيده نهائيا. والانتهاء منها. المقررات الدراسية بالدبلوم الخاص السنة الأولي والثانية:

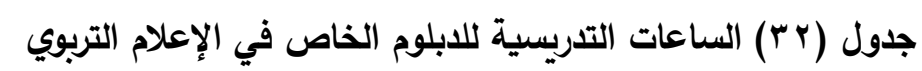

\begin{tabular}{|c|c|c|c|c|c|c|c|c|}
\hline \multicolumn{4}{|c|}{ النهاية العظمي للارجات } & \multicolumn{3}{|c|}{ الساعات الأسبوعية } & \multirow[b]{2}{*}{ المقررات الدراسية } & \multirow[t]{2}{*}{ b } \\
\hline 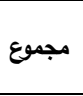 & تطبيقي & أعمال سنة & 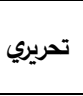 & 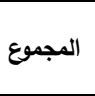 & تطبيقي & 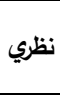 & & \\
\hline ๑. & - & 1. & $\varepsilon$. & r & & r & سيكولوجية الإبداع & 1 \\
\hline$\circ$. & - & 1. & $\varepsilon$ & r & & r & نظم التعليم المقارنة في مجال التخصص & r \\
\hline •. & - & 1. & $\varepsilon$. & r & & r & مناهج البحث والإحصاء & $r$ \\
\hline $1 \ldots$ & $r$ r. & $r \cdot$ & 7. & $\varepsilon$ & r & r & الحاسب الآلي واستخدامه في التخصص & $\varepsilon$ \\
\hline $1 \ldots$ & $r$ r. & $r$ r. & 7. & $\varepsilon$ & r & $r$ & المسرح التربوي & 0 \\
\hline $1 \ldots$ & $r$. & $r$. & 7. & $\varepsilon$ & r & $r$ & دراسات في علوم الصحافة ووسائل الإعلام & 7 \\
\hline $1 \ldots$ & $r \cdot$ & $r \cdot$ & 7. & $\varepsilon$ & r & r & دراسات في الإذاعة والتليفزيون التعليمي & $v$ \\
\hline $1 \ldots$ & r. & $r \cdot$ & 7. & $\varepsilon$ & r & r & العلاقات العامة والإعلان & $\wedge$ \\
\hline ro. & - & - & - & & Y & & إجمالي & \\
\hline
\end{tabular}




\begin{tabular}{|c|c|c|c|c|c|c|c|c|}
\hline \multicolumn{9}{|c|}{ جدول (بr) الساعات التدربسية للابلوم الخاص في الإعلام التربوي } \\
\hline \multicolumn{4}{|c|}{ ال النهاية العظمي للارجات } & \multicolumn{3}{|c|}{ الساعات الأسبوعية } & \multirow[t]{2}{*}{ المقررات الدراسية } & \multirow[t]{2}{*}{ b } \\
\hline 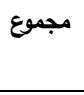 & تطبيقي & أعمال سنة & 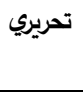 & 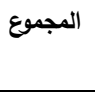 & تطبيقي & نظري & & \\
\hline ๑. & - & 1. & $\varepsilon$ & r & & r & أسس وتطوير المناهج & 1 \\
\hline ○. & - & 1. & $\varepsilon$ & $r$ & & $r$ & تكنولوجيا التعليم & r \\
\hline ๑. & - & 1. & $\varepsilon$ & r & & r & حلقة بحث & $r$ \\
\hline $1 \ldots$ & r. & r. & $\checkmark$. & $\varepsilon$ & $r$ & r & الحاسب الآلي واستخذامه في التخصص & $\varepsilon$ \\
\hline $1 \ldots$ & $r$. & r. & 7. & $\varepsilon$ & $r$ & r & التحرير والإخراج الصحفي & 。 \\
\hline $1 \ldots$ & r. & r. & 7. & $\varepsilon$ & r & r & المسرحة المناهج ونظريات الإخراج & 9 \\
\hline $1 \ldots$ & $r$. & r. & 7. & $\varepsilon$ & $r$ & $r$ & نظريات الاتصال & $v$ \\
\hline $1 \ldots$ & $r$. & r. & 7. & $\varepsilon$ & $r$ & r & الميختادة الاختيارية في التخصص الذانب لبحثه & $\wedge$ \\
\hline 70. & - & - & - & & Y & & إجمالي & \\
\hline
\end{tabular}

لخمس مقررات في مجـال الإعـلام (الحاسب الآلـي واسـتخدامه فـي التخصـص، التحريـر والإخراج الصحفي، مسرحة المناهج ونظريات الإخراج المسرحي، نظريـات الاتصـال، المـادة

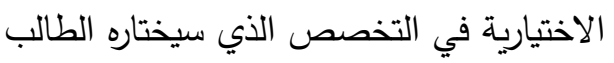

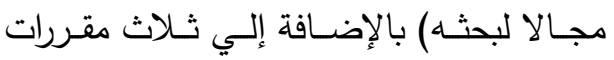

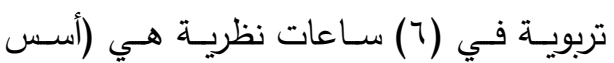

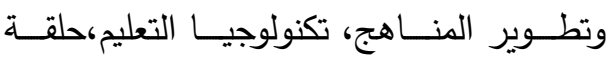

$$
\text { بحث). }
$$

وبالتالي يكون إجمالي ساعات المقررات الدراسية بالدبلوم الخاص علي مدار العامين

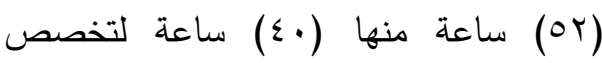
الإعلام بما فيها مقرري استخدام الحاسب سلاعبه الآلي في التخصص علي مدار العامين، (Y I (T) ساعة مواد تربوية بما فيها مقرر تكنولوجيا التعليم في ساعتين.
بتحليل المقررات الدراسية بلائحة الكلية في السنة الأولي والثانية يتضح أن الطالب

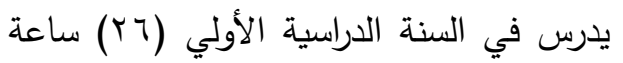

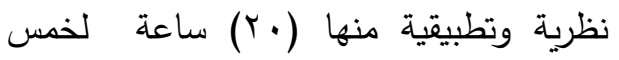
مقررات في مجال الإعلام هي (الحاسب الآلي

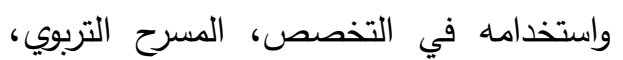
دراسات في علوم الصحافة ووسائل الإعلام، دراسات في الإذاعة والتليفزيون التعليمي، العلاقات العامة والإعلان)، أي مقرر في كل الإدهات تخصص ، بالإضافة لثلاث مقررات تربوية في

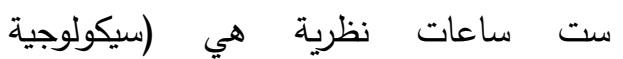
الإبداع،نظم التعليم المقارنة في مجاعيه التخصص، مناهج البحث والإحصاء) أي مجئ

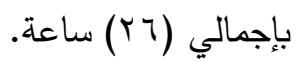

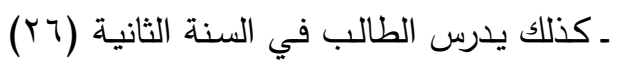

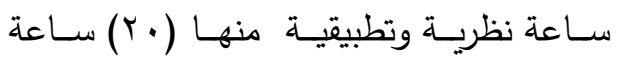


ل لم يدرس الطالب في السنة الثانية أي مقرر .لا يوجد توصيف للمقررات الدراسية أو تعريف بمفردات كل مقرر باللائحة، ولا يوجد في مجال الإذاعة والتليفزيون. · يوجد تكرار في تدريس مقرر استخدام توصيف للمقررات الدراسية متاح للاطلاع عليه

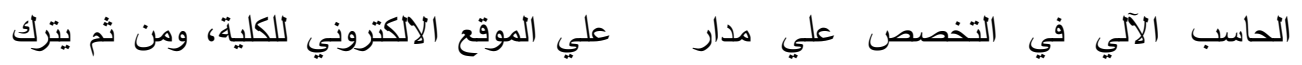

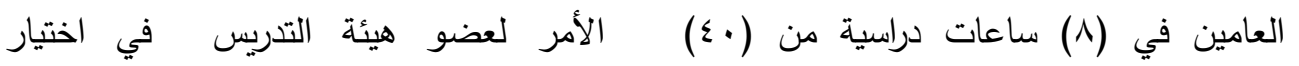

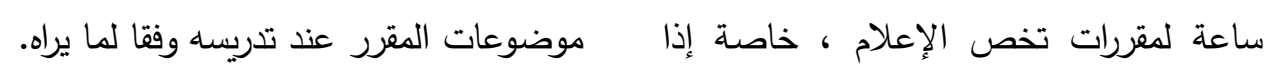

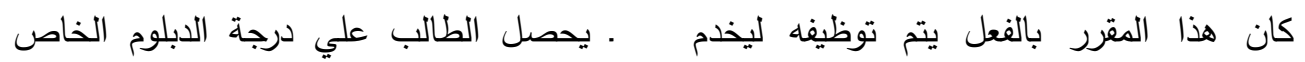
في الإعلام التربوي دون وجود تخصص دقيق، تخصصات الإعلام التربوي الثلاثة.

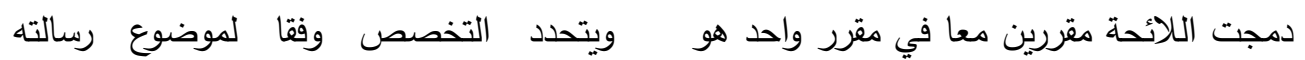

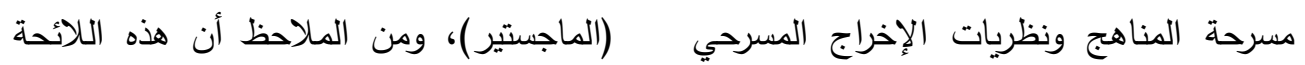

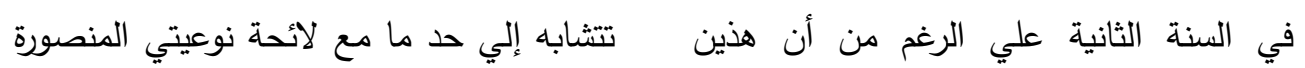

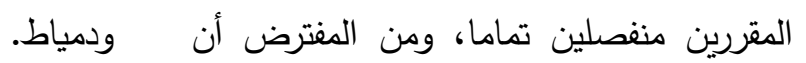

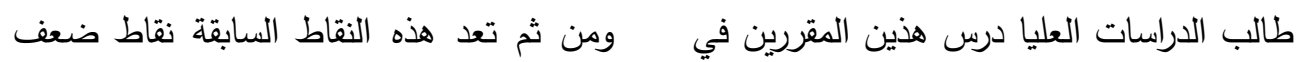
مرحلة البكالوريوس،وبالتالي فإن الطالب يدرس تحتاج إلي تحسين وإعادة النظر في في مقردات

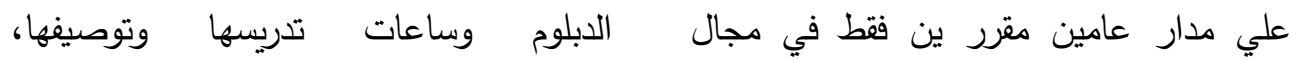
المسرح (المسرح التزبوي في السنة الأولي، والتخصص فين ، ودراسة مقرر في اللغة الانجليزية مسرحة المناهج ونظريات الإخراج في السنة في التخصص.

\section{r. برنامج الماجستير في الإعلام التربوي:}

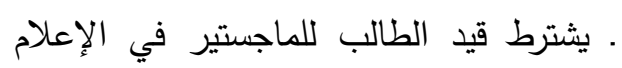

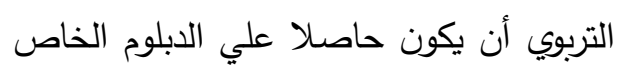
في التربية النوعية بتقدير جيد من إحدى كليات

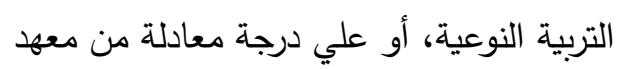
علمي معترف به، وعلي تقدير جيد جدا في مقررات التخصص، والثرط الأخير لا تأخذ به كليات التربية النوعية المناظرة وتكتفي بحصول الطالب علي تقدير جيد في الدبلوم الخاص. الثانية بإجمالي (^) ساعات نظرية وعملية

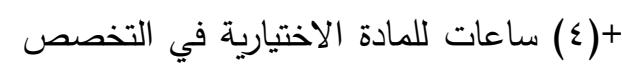

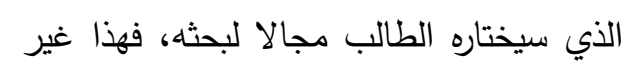
كاف لإعداد الطالب للحصول علي الدبلوم

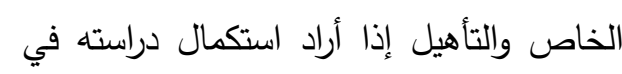

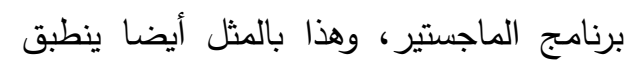

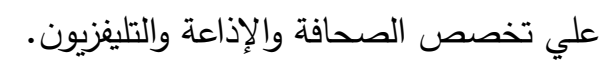

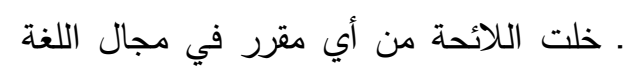
الانجليزية أو مقرر ترجمة إعلامية في مجال 


\section{• يدرس الطالب بعد قيده لبرنامج الماجستير أ. مقررات الماجستير في مجال الصحافة والإذاعة والتليفزيون:

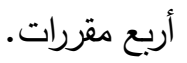

جدول (ع ب) مقررات الماجستير في مجال الصحافة والإذاعة والتليفزيون

\begin{tabular}{|c|c|c|c|c|c|c|c|c|}
\hline \multicolumn{4}{|c|}{ النهاية العظمي للارجات } & \multicolumn{3}{|c|}{ الساعات الأسبوعية } & \multirow[b]{2}{*}{ 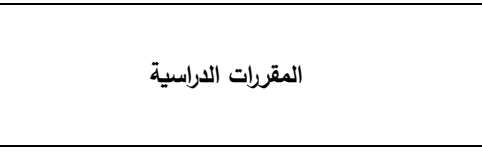 } & م \\
\hline 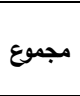 & 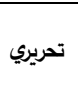 & تطبيقي & أعمال سنة & 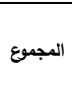 & تطبيقي & نظري & & \\
\hline $1 \cdots$ & $\varepsilon$. & $\varepsilon$. & $r \cdot$ & $r$ & r & 1 & الإحصاء وتطبيقات الحاسب في مجال التخصص & 1 \\
\hline $1 \ldots$ & $\wedge$. & - & r. & $r$ & - & $r$ & مقرر أجنبي دراسات في تكنولوجيا الاتصال الحليثة & $r$ \\
\hline $1 \ldots$ & $\wedge$. & - & $r \cdot$ & $r$ & - & $r$ & مقرر عربي التحرير والإنتاج الإعلامي الإعلام الجديد & $r$ \\
\hline $1 \ldots$ & - & - & $1 \ldots$ & $r$ & - & $r$ & حلقة بحث ( حمث & $\varepsilon$ \\
\hline
\end{tabular}

ب ـ مقررات ماجستير الإعلام التربوي في مجال الفنون المسرحية:

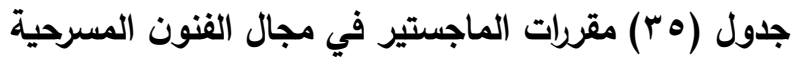

\begin{tabular}{|c|c|c|c|c|c|c|c|c|}
\hline \multicolumn{4}{|c|}{ النهاية العظمي للارجات } & \multicolumn{3}{|c|}{ الساعات الأسبوعية } & \multirow[b]{2}{*}{ المقرات الدراسية } & \multirow[t]{2}{*}{ p } \\
\hline 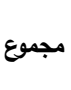 & 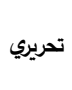 & تطبيقي & أعمال سنة & 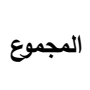 & تطبيقي & نظري & & \\
\hline $1 \ldots$ & $\varepsilon$. & 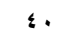 & $r \cdot$ & $r$ & r & 1 & الإحصاء وتطبيقات الحاسب في مجال التخصص & 1 \\
\hline $1 \ldots$ & $\wedge$. & - & $r$ r. & $r$ & - & $r$ & مقرر أجنبي نظريات تمثيل وإخراج & r \\
\hline $1 \ldots$ & $\wedge$. & - & r. & $r$ & - & $r$ & مقرر أجنبي الاتجاهات التجريبية الحديثة في & $r$ \\
\hline $1 \ldots$ & - & - & $1 \ldots$ & $r$ & - & $r$ & حلقة بحث & $\varepsilon$ \\
\hline
\end{tabular}

من الدرجة. وهذه التقديرات تتشابه مع لوائح كليات التربية النوعية الأخرى. . للطالب الحق في مناقشة رسالته للماجستير خلال عام من تاريخ موافقة مجلس الكلية علي

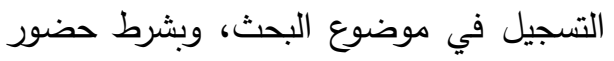

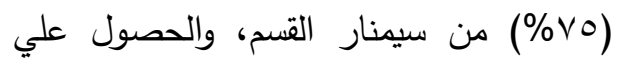
شهادة التويفل كشرط للمناقثة بدرجة ( . . ع). • دمجت اللائحة مقررات ماجستير الصحافة والإذاعة والتليفزيون في تخصص واحد.

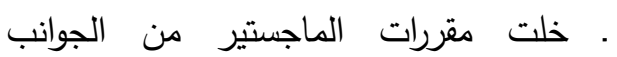
التطبيقية والعملية في التخصصات (الصحافة

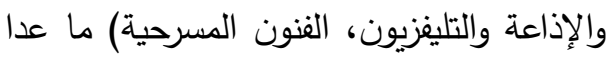
مقرر الإحصاء وتطبيقات الحاسب في مجال
· ويكون نجاح الطالب فيها بحصوله علي ( • (\% من الدرجة ويؤدي الامتحان في ثلاث

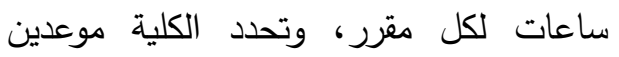

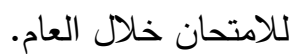
ـ تحسب تقدير الطالب في المقرر أو المجموع الكلي للدرجات بالنسبة للدبلوم والماجستير بالتقديرات التالية:(ممتاز 9 \% فأكثر ،جيد

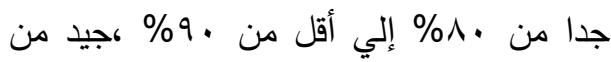

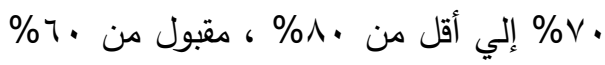

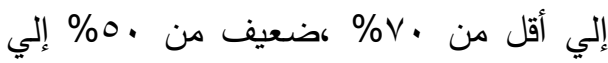

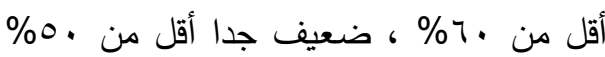




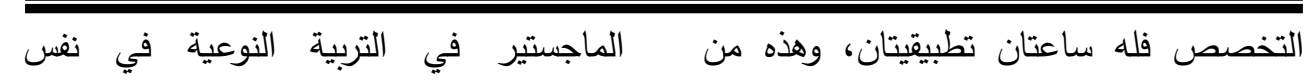
التخصص من إحدى جامعات جمهورية مصر فئية النقاط التي تحتاج إلي تحسين وتطوير .

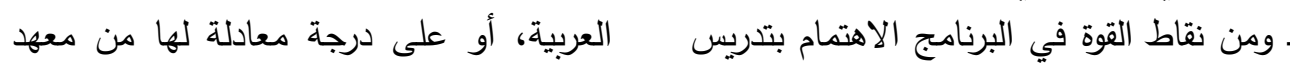

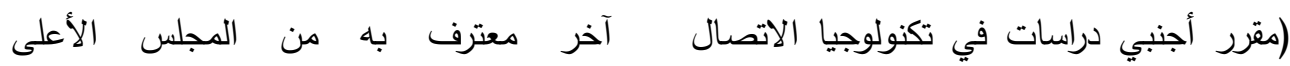

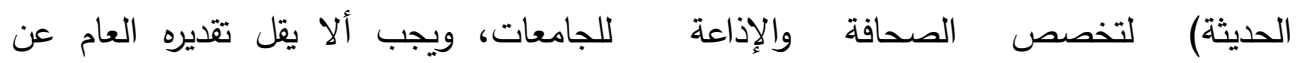
والتليفزيون، ومقرين في تخصص المسرح (جيد) في ماجستير التربية النوعية.

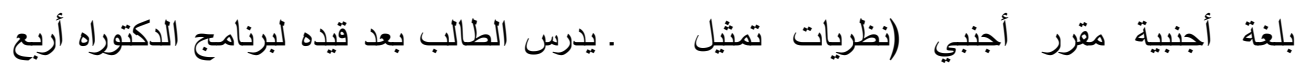
وإخراج، الاتجاهات التجريبية الحديثة في مجال مقررات كالتالي: أ. مقررات الاكتوراه مجال الصحافة والإذاعة والتليفزيون: r. برنامج الاكتوراه: يشترط قيد الطالب لبرنامج الدكتوراه في الأبوري

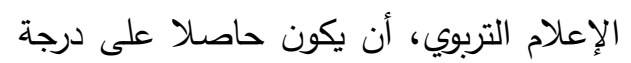

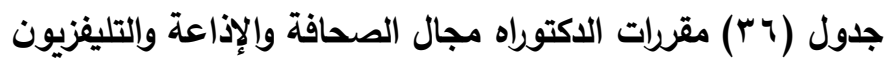

\begin{tabular}{|c|c|c|c|c|c|c|c|c|}
\hline \multicolumn{4}{|c|}{ النهاية العظمي للارجات } & \multicolumn{3}{|c|}{ الساعات الأسبوعية } & \multirow[b]{2}{*}{ المقررات الدراسية } & \multirow[b]{2}{*}{ 5 } \\
\hline 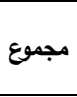 & 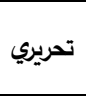 & تطبيقي & أعمال سنة & المجموع & تطبيقي & نظري & & \\
\hline $1 \cdots$ & $\varepsilon$ & $\varepsilon$ & $r \cdot$ & $r$ & r & 1 & الإحصاء وتطبيقات الحاسب في التخصص & 1 \\
\hline $1 \ldots$ & $\varepsilon$ & $\varepsilon$ & $r$. & $r$ & 1 & r & مقرر عربي نظريات الإعلام الحديثة في التخصص & r \\
\hline $1 \cdots$ & $\varepsilon$ & $\varepsilon$ & r. & $r$ & 1 & r & دراسات في الإعلام الجديد & $r$ \\
\hline $1 \ldots$ & - & - & $1 \ldots$ & $r$ & & $r$ & حلقة بحث & $\varepsilon$ \\
\hline
\end{tabular}

ب ـ مقرات الدكتوراه في مجال الفنون المسرحية: جدول (rv) مقررات الاكتوراه في مجال الفنون المسرحية

\begin{tabular}{|c|c|c|c|c|c|c|c|c|}
\hline \multicolumn{4}{|c|}{ النهاية العظمي للدرجات } & \multicolumn{3}{|c|}{ الساعات الأسبوعية } & \multirow[t]{2}{*}{ المقررات الدراسية } & \multirow[t]{2}{*}{ s } \\
\hline 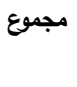 & 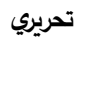 & تطبيقي & أعمال سنة & 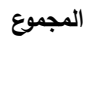 & تطبيقي & 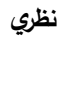 & & \\
\hline $1 \ldots$ & $\varepsilon$ & $\varepsilon$ & r. & $r$ & r & 1 & الإحصاء وتطبيقات الحاسب في التخصص & 1 \\
\hline $1 \ldots$ & $\varepsilon$ & $\varepsilon$. & $r \cdot$ & $r$ & 1 & r & مقرر عربي نظريات تمثيل وإخراج متقدم & r \\
\hline $1 \ldots$ & 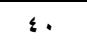 & $\varepsilon$ & r. & $r$ & 1 & r & مدارس حديثة في المسرح & $r$ \\
\hline $1 \ldots$ & - & - & $1 \ldots$ & $r$ & & $r$ & حلقة بحث & $\varepsilon$ \\
\hline
\end{tabular}

بحد أدني، قبل تشكيل لجنة المناقشة

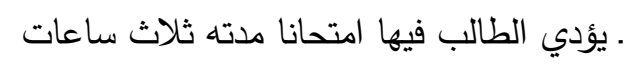
والحكم، ولا يجوز للطالب أن يؤدي فيها

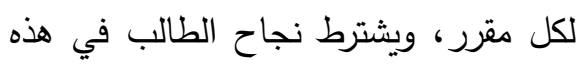
الامتحان أكثر من مرتين، ويحسب تقدير

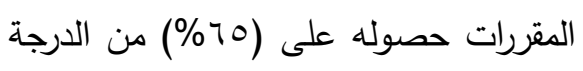




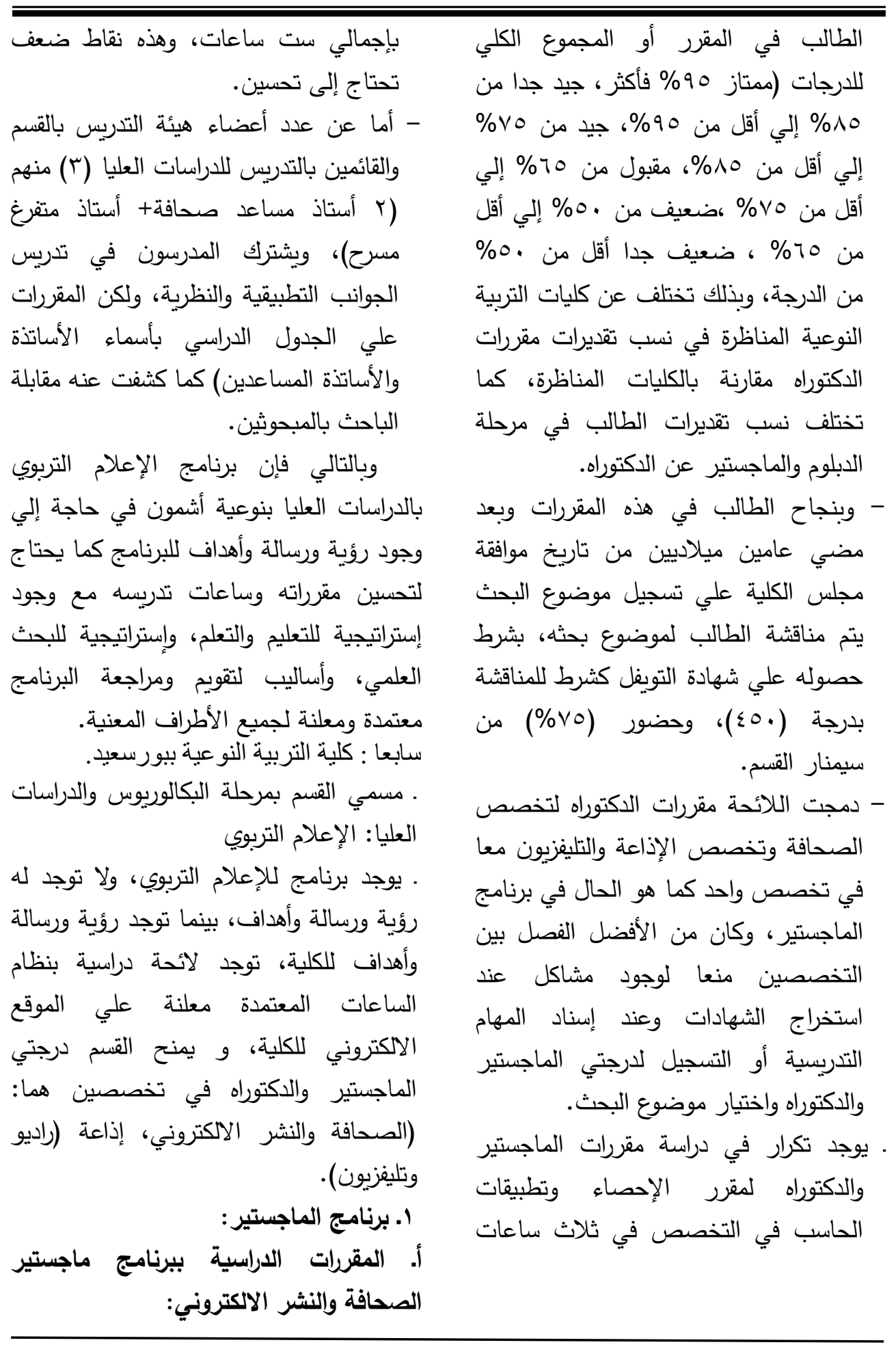


جدول (r^) الساعات التدريسية لبرنامج الماجستير في الإعلام التربوي تخصص(صحافة ونشر الكتروني)

\begin{tabular}{|c|c|c|c|c|c|c|c|c|c|c|c|}
\hline \multicolumn{2}{|c|}{ زمن الامتحان } & \multicolumn{4}{|c|}{ درجات الامتحان النهائي } & \multirow{2}{*}{ سنة أعمال } & \multicolumn{3}{|c|}{ عدد الساعات الأسبوعية } & \multirow[t]{2}{*}{ المقررات اللاراسية } & \multirow[t]{2}{*}{ p } \\
\hline تطبيقي & نظري & مجموع & نظري & شفوي & تطبيقي & & معتمدة & تطبيقي & نظري & & \\
\hline \multicolumn{12}{|c|}{ المقررات الدراسية الإجبارية (01) ساعات معتدة } \\
\hline r & r & $1 \ldots$ & . & - & $\varepsilon$. & r. & r & r & 1 & صحافة الانترنت & 1 \\
\hline r & $r$ & 1.. & $\varepsilon$. & - & $\varepsilon$ & r. & r & r & 1 & الصحفي خاص في التحرير & r \\
\hline r & r & 1.. & ؛. & - & ؛. & r. & r & r & r & الصوضف الاكترونية في إخراج & $r$ \\
\hline r & r & $1 \ldots$ & ؛. & - & ؛. & r. & $r$ & r & r & إعلامية باللغة الانجليزية & $\varepsilon$ \\
\hline- & r & 1.. & ^. & - & - & r. & r & - & r & ألكالاقيات وقوانين الصحافة & . \\
\hline r & r & 1.. & 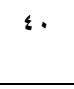 & - & ؛. & r. & r & r & r & للنثر الاكتروني الصوت والفيديو & 7 \\
\hline \multicolumn{12}{|c|}{ مقررات تخصصية اختيارية (يختار الطالب IV ساعة متثدة) } \\
\hline- & r & $1 \ldots$ & A. & - & - & r. & r & - & $r$ & تكنولويبا الاتصال والمعلومات & 1 \\
\hline$r$ & $r$ & $1 \ldots$ & «. & - & $\varepsilon$. & $r$. & $r$ & $r$ & 1 & الرأي العام وبحوث الإعلام & $r$ \\
\hline- & $r$ & $1 \ldots$ & A. & - & - & $r$. & $r$ & - & $r$ & نحو وصرف & $r$ \\
\hline- & $r$ & $1 \ldots$ & A. & - & - & r. & r & - & $r$ & علم السياسة والنظم السياسية & $\varepsilon$ \\
\hline- & $r$ & $1 .$. & A. & - & - & $r$. & $r$ & - & $r$ & الاعاية ونشر المستحدثات & - \\
\hline$r$ & $r$ & $1 \ldots$ & $\vdots$. & - & «. & $r$. & $r$ & $r$ & 1 & كتابة بحث متخصص في الصحافة & 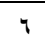 \\
\hline$r$ & $r$ & $1 .$. & $\Leftrightarrow$. & - & $\varepsilon$ & $r$. & $\mu$ & $r$ & $r$ & بحوث الإعلام التزبوي & 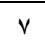 \\
\hline$r$ & $r$ & $1 \ldots$ & $\varepsilon$. & - & «. & r. & $r$ & $r$ & $r$ & إحصاء وقياس الرأي العام & $\wedge$ \\
\hline$r$ & $r$ & $1 \cdots$ & $\varepsilon$. & - & $\varepsilon$ & $r$. & $r$ & $r$ & $r$ & الدتخصص متقدة في الإعلام & 9 \\
\hline \multicolumn{12}{|c|}{ المقرات التربوية الإجبارية (^) ساعات معتمدة } \\
\hline- & $r$ & $1 \ldots$ & $r$ & $r$. & - & $r$. & $r$ & - & $r$ & مناهج بحث & 1 \\
\hline$r$ & r & $1 \ldots$ & ؛. & - & ؛. & $r$. & $\varepsilon$ & 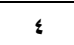 & r & الإحصاء وتحليل البيانات & $r$ \\
\hline r & r & $1 \cdots$ & . & - & $\varepsilon$ & r. & $r$ & r & 1 & طرق تدريس متقدم في & $r$ \\
\hline
\end{tabular}

ب ـ المقررات الدراسية ببرنامج الماجستير إذاعة (راديو وتليفزيون):

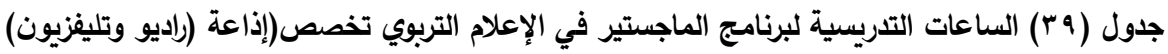

\begin{tabular}{|c|c|c|c|c|c|c|c|c|c|c|c|}
\hline \multicolumn{2}{|c|}{ زمن الامتحان } & \multicolumn{4}{|c|}{ درجات الامتحان النهائي } & \multirow{2}{*}{ سنة أعمال } & \multicolumn{3}{|c|}{ عدد الساعات الأسبوعية } & \multirow[b]{2}{*}{ المقررات الدراسية } & \\
\hline تطبيقي & نظري & مجموع & نظري & شفوي & تطبيقي & & المتسدة & تطبيقي & نظري & & \\
\hline \multicolumn{12}{|c|}{ المقرات الدراسية الإجبارية (ه (1) ساعات معتدة } \\
\hline r & r & $1 \ldots$ & 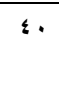 & - & ؛. & r. & $r$ & r & 1 & $\begin{array}{r}\text { والثبامتج التعليمية } \\
\text { والثقافية }\end{array}$ & 1 \\
\hline$r$ & $r$ & $1 \ldots$ & $\varepsilon$. & - & ؛. & $r$. & $r$ & $r$ & 1 & الإلقاء والتقديم & r \\
\hline
\end{tabular}




\begin{tabular}{|c|c|c|c|c|c|c|c|c|c|c|c|}
\hline r & r & $1 \ldots$ & $\wedge$. & - & - & $r$. & r & - & r & والإذاعات الإقليمية & $r$ \\
\hline r & r & $1 \ldots$ & $\varepsilon$ & - & $\varepsilon$ & $r \cdot$ & $r$ & $r$ & $r$ & إعلامية باللغة الانجليزية & $\varepsilon$ \\
\hline r & r & $1 \ldots$ & $\varepsilon$ & - & $\varepsilon$ & $r \cdot$ & $r$ & r & r & الفيلم الوثائقي & 0 \\
\hline r & $r$ & $1 \ldots$ & $\varepsilon$. & - & $\varepsilon$. & $r \cdot$ & $r$ & $r$ & $r$ & $\begin{array}{r}\text { إنتاج الأخبار والبرامتجة } \\
\text { الإعية }\end{array}$ & 9 \\
\hline \multicolumn{12}{|c|}{ مقررات تخصصية اختيارية (يختار الطالب V ساعة معتمدة) } \\
\hline- & r & $1 \ldots$ & $\wedge$. & - & - & r. & r & - & r & تكنولوجيا الاتصال & 1 \\
\hline r & r & $1 \cdots$ & $\varepsilon$ & - & $\varepsilon$. & r. & r & r & 1 & الرأي العام وبحوث & r \\
\hline- & r & $1 \ldots$ & $\Lambda$. & - & - & r. & r & - & r & نحو وصرف & r \\
\hline- & r & $1 \cdots$ & $\wedge$. & - & - & r. & r & - & r & علم السياسة والنظم & $\varepsilon$ \\
\hline - & r & $1 \ldots$ & $\wedge$. & - & - & r. & r & - & r & الاعاية ونشر & 0 \\
\hline r & $r$ & $1 \ldots$ & $\varepsilon$ & - & 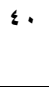 & $r \cdot$ & r & $r$ & 1 & كتابة بحث متخصص في & 7 \\
\hline r & r & $1 \ldots$ & $\varepsilon$. & - & $\varepsilon$ & $r$. & $r$ & $r$ & $r$ & بحوث الإعلام التربوي & v \\
\hline r & r & $1 \cdots$ & $\varepsilon$. & - & $\varepsilon$ & r. & $r$ & $r$ & $r$ & إحصاء وقياس الرأي & $\wedge$ \\
\hline$r$ & $r$ & $1 \ldots$ & $\varepsilon$ & - & $\varepsilon$ & $r \cdot$ & $r$ & $r$ & $r$ & الإعلام المتخصصات متقدمة في & 9 \\
\hline \multicolumn{12}{|c|}{ المقرات التربوية الإجبارية (^) ساعات معتمدة } \\
\hline- & $r$ & $1 \cdots$ & 7. & $r \cdot$ & - & $r \cdot$ & r & - & r & مناهج بحث & 1 \\
\hline$r$ & $r$ & $1 \cdots$ & $\varepsilon$. & - & $\varepsilon$ & $r$. & $\varepsilon$ & $\varepsilon$ & $r$ & الإحصاء وتحليل البيانات & r \\
\hline 1 & r & $1 \cdots$ & $\varepsilon$ & - & $\varepsilon$. & $r$. & r & r & 1 & طرق تدريس متقدم في & $r$ \\
\hline
\end{tabular}

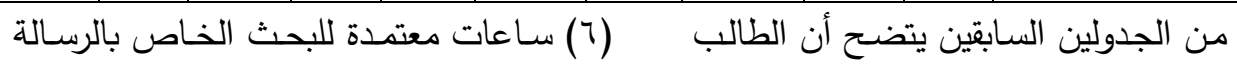

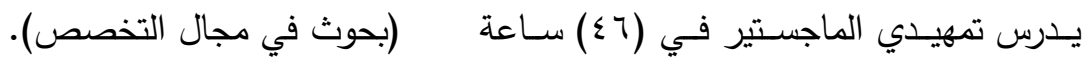

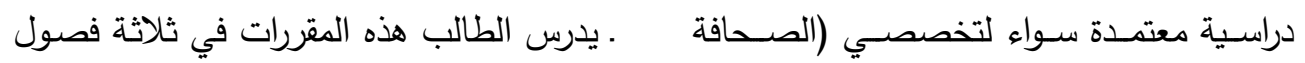

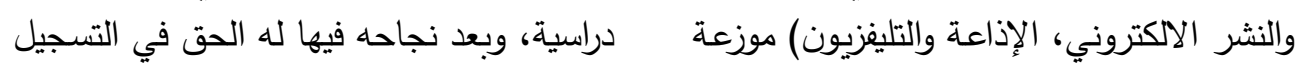

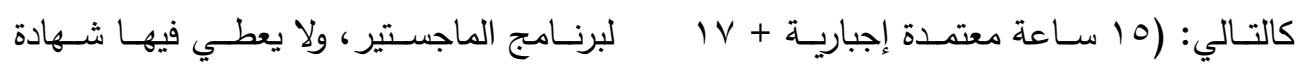

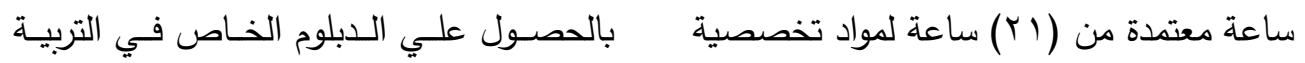
اختيارية + 1 ساعات معتمدة مقررات تربوية+ النوعية، بعكس نوعية بنها التي تعطي شهادة 
أهميـة التدريبات العمليـة والتطبيقيـة، واللائحسة

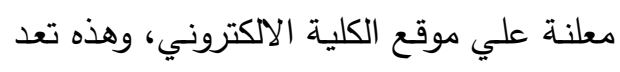

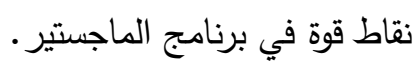

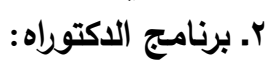

أ. المقررات الاراسية بيرنـامج دكتوراه الفلسفة

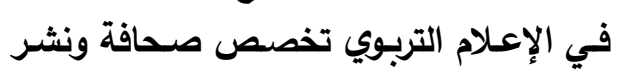
الكتروني: - الإعام

بالحصـول علـي الــبلوم الخـاص بعـد نجـاح الطالب في دراسة الفصول الدراسية. ـ مقرر علم السياسة والنظم السياسية هو مقرر

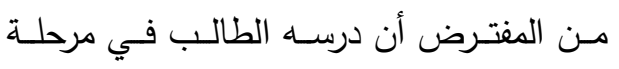

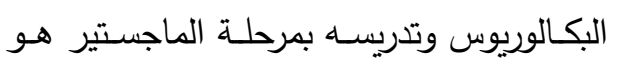
تكرار لما تم دراسته من قبل.

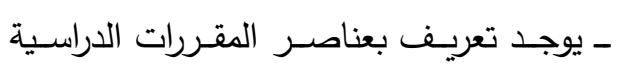

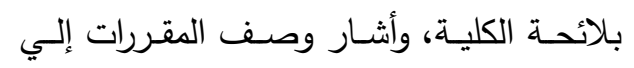

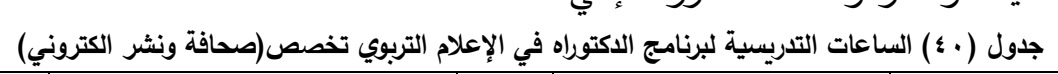

\begin{tabular}{|c|c|c|c|c|c|c|c|c|c|c|c|}
\hline \multicolumn{2}{|c|}{ 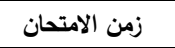 } & \multicolumn{4}{|c|}{ درجات الامتحان النهائي } & \multirow{2}{*}{ سنة } & \multicolumn{3}{|c|}{ عدد الساعات الأسبوعية } & \multirow[t]{2}{*}{ 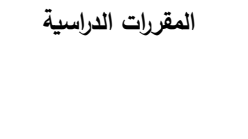 } & \multirow[t]{2}{*}{ b } \\
\hline ت تطبيقي & نظري & 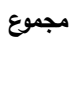 & نظري & شفوي & ت تطبيقي & & المعاعات & تطبيقي & 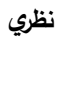 & & \\
\hline \multicolumn{12}{|c|}{ المقررات الدراسية الإجبارية (^ ا ) ساعات معتمدة } \\
\hline r & r & $1 \ldots$ & $\leq$ & - & $\varepsilon$ & r. & $r$ & r & r & دالاتجاهات المعاصرة في & 1 \\
\hline- & r & $1 \ldots$ & $\wedge$. & - & - & r. & $r$ & - & $r$ & سوسيولوجيا المجتمع الرقمي & r \\
\hline r & r & $1 \ldots$ & $\varepsilon$ & - & $\varepsilon$ & r. & $r$ & r & r & مهارات ملتميديا النشر الاكتروني & $r$ \\
\hline r & r & $1 \ldots$ & $\varepsilon$ & - & $\varepsilon$ & r. & $r$ & r & r & كتابة وتصميم الإعلانات الصحفية & $\varepsilon$ \\
\hline$r$ & $r$ & $1 \ldots$ & $\varepsilon$ & - & $\varepsilon$ & $r$. & $r$ & r & r & تطبيقات في نظريات الإعلام & • \\
\hline$r$ & $r$ & $1 \ldots$ & $\varepsilon$. & - & $\varepsilon$ & r. & $r$ & r & $r$ & إدارة القضايا والأزمات إعلاميا & 7 \\
\hline \multicolumn{12}{|c|}{ مقررات تخصصية اختيارية (يختار الطالب 1 ساعة معتمدة) } \\
\hline r & r & $1 \ldots$ & $\varepsilon$. & - & $\varepsilon$ & r. & $r$ & r & $r$ & أسس التصميم الجرافيكي & 1 \\
\hline- & r & $1 \ldots$ & $\wedge$. & - & - & $r \cdot$ & r & - & r & موضوعات في الاقتصاد & r \\
\hline- & r & $1 \ldots$ & $\wedge$. & - & - & $r$. & $r$ & - & $r$ & إدارة المؤسسات الإعلامية & $r$ \\
\hline r & r & $1 \ldots$ & $\varepsilon$ & - & $\varepsilon$ & $r$. & $r$ & r & r & الحملات الصحفية & $\varepsilon$ \\
\hline- & r & $1 \ldots$ & $\wedge$. & - & - & r. & $r$ & - & $r$ & الإعلام الاولي & • \\
\hline r & $r$ & $1 \ldots$ & $\varepsilon$ & - & $\varepsilon$ & $r$. & $r$ & r & r & دراسات متقدمة في الدعاية & 7 \\
\hline \multicolumn{12}{|c|}{ المقررات التربوية الإجبارية (ع ) ساعات معتمدة } \\
\hline r & r & $1 \ldots$ & $\varepsilon$. & - & $\varepsilon$. & r. & r & r & 1 & بناء أدوات القياس في التخصص & 1 \\
\hline- & r & $1 \ldots$ & $\Lambda$ & - & - & r. & r & - & r & إحصاء متقدم & r \\
\hline
\end{tabular}

ب ـ المقرات الدراسية ببرنامج دكتوراه الفلسفة في الإعلام التربوي تخصص إذاعة وتليفزيون:

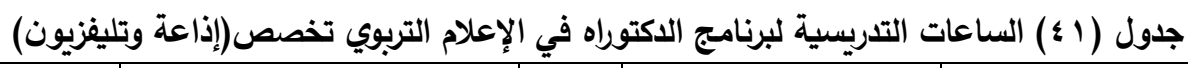

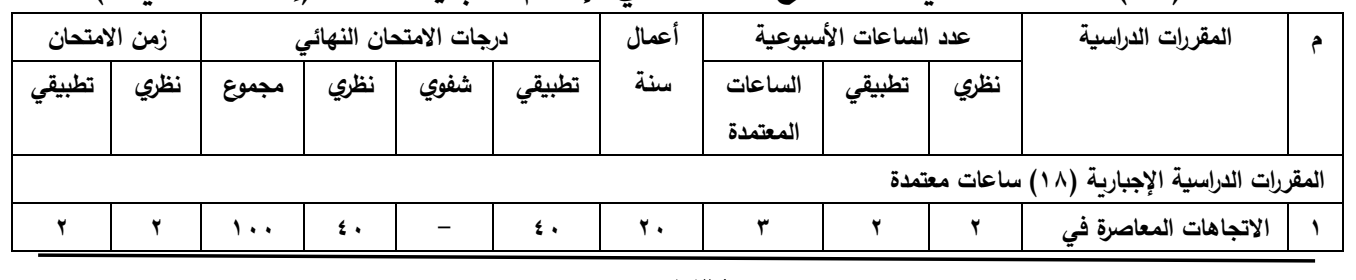
I $\mathrm{\mu \Lambda}$ 


\begin{tabular}{|c|c|c|c|c|c|c|c|c|c|c|c|}
\hline & & & & & & & & & & دراسات الاتصال & \\
\hline- & r & $1 \ldots$ & $\wedge$. & - & - & r. & $r$ & - & $r$ & التخطيط الإذاعي & r \\
\hline r & r & $1 \ldots$ & $\varepsilon$ & - & $\varepsilon$. & $r \cdot$ & $r$ & r & $r$ & الإذاعات عبر الانترنت & $r$ \\
\hline r & r & $1 \ldots$ & $\varepsilon$ & - & $\varepsilon$ & r. & $r$ & r & $r$ & 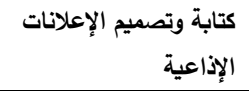 & $\varepsilon$ \\
\hline r & r & $1 \ldots$ & $\varepsilon$ & - & $\varepsilon$ & r. & $r$ & r & r & تطبيقات في نظريات & ○ \\
\hline r & r & $1 \ldots$ & $\varepsilon$ & - & $\varepsilon$. & r. & $r$ & r & r & $\begin{array}{r}\text { إدارة القضايا والأزمات } \\
\text { إعلاتيات }\end{array}$ & 7 \\
\hline \multicolumn{12}{|c|}{ مقررات تخصصية اختيارية (يختار الطالب 1 ساعة معتمدة) } \\
\hline r & r & $1 \ldots$ & $\varepsilon$ & - & $\varepsilon$ & r. & $r$ & r & r & أسس التصميم الجرافيكي & 1 \\
\hline- & r & $1 \ldots$ & $\wedge$. & - & - & r. & r & - & r & موضوعات في الاقتصاد & r \\
\hline- & r & $1 \ldots$ & $\wedge$. & - & - & r. & $r$ & - & $r$ & إدارة المؤسسات الإعلامية & $r$ \\
\hline$r$ & r & $1 \ldots$ & $\varepsilon$ & - & $\varepsilon$ & r. & $r$ & r & r & والتليفزيوت الإعلامية للراديو & $\varepsilon$ \\
\hline- & r & $1 \ldots$ & $\wedge$. & - & - & r. & $r$ & - & $r$ & الإعلام الدولي & $\bullet$ \\
\hline$r$ & r & $1 \cdots$ & $\varepsilon$ & - & $\varepsilon$. & r. & $r$ & r & r & الدراسات متقدمة في & 7 \\
\hline \multicolumn{12}{|c|}{ المقررات التربوية الإجبارية (؛ ) ساعات معتمدة } \\
\hline$r$ & r & $1 \cdots$ & $\varepsilon$. & - & $\varepsilon$ & $r$. & r & r & 1 & بناء أدوات القياس في & 1 \\
\hline- & r & $1 \ldots$ & $\wedge$. & - & - & $r \cdot$ & r & - & r & إحصاء متقدم & r \\
\hline
\end{tabular}

من هذين الجدولين يتضح أن الطالب أنه يوجد أربعة مقررات دراسية من المفترض

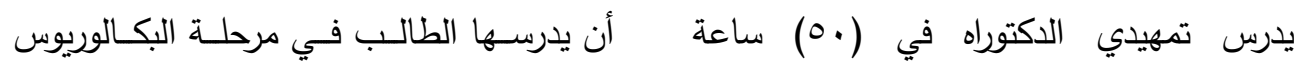

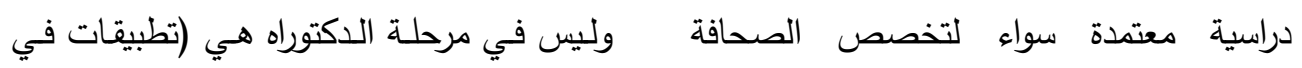

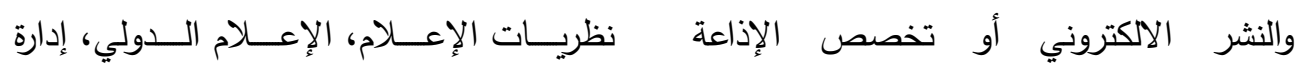

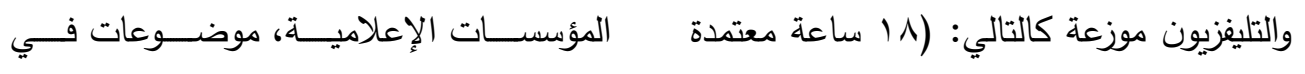
مواد إجبارية تخصصية + 17 ساعة معتمدة الاقتصاده).

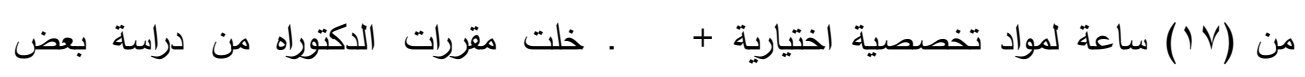

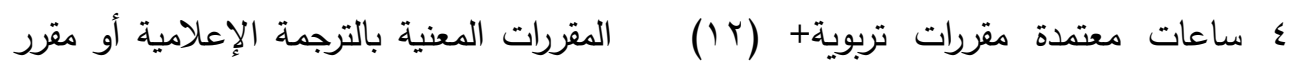

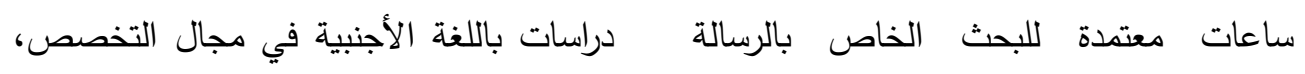

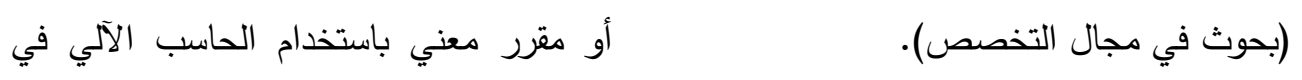

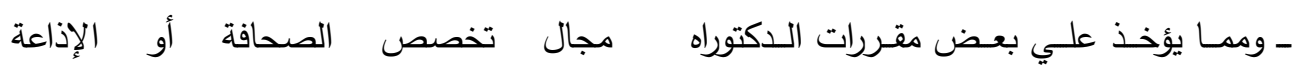
للتخصصـين (الصـحافة، الإذاعـة والتليفزيـون) والتليفزيون، أو مقرر معني بالإعلام التربوي 
يحتاج لتحسين مقرراته وساعات تدريسه مع وجود إستراتيجية للتعليم والتعلم، وإستراتيجية

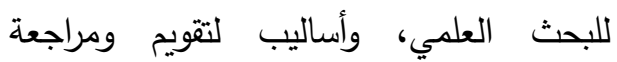

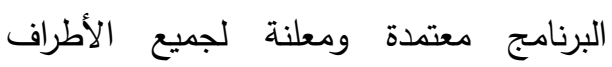

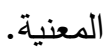
ثامنا : كلية التربية النوعية بالمنيا جامعة المنيا: • مسمي القسم بمرحلة البكالوريوس والدراسات العليا قسم الإعلام التربوي.

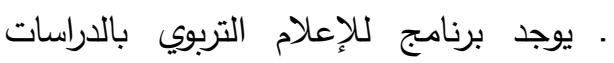
العليا، وتوجد رؤية ورسالة وأهداف إستراتيجية

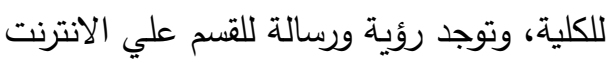
وهذا غير متوفر لبرامج الإعلام التربوي

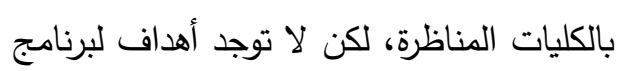
الإعلام التربوي بالدراسات العليا، وتوجد لائحة بنظام الساعات الدراسية، ويوجد دليل لطلاب الدراسات العليا.

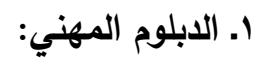

• يمنح القسم درجة الدبلوم المهني في الإعلام التربوي، ويشترط الحصول عليه أن يكون

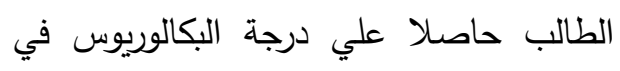
الإعلام التربوي أو علي درجة معادلة لها من

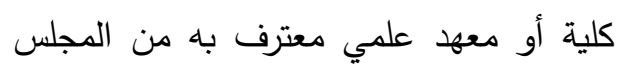
الأعلى للجامعات واجتياز اختبارات القبول، ومدة الدراسة بالدبلوم المهني سنة جامعية

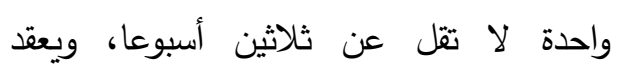
للطالب امتحان في نهاية العام، وإذا تغيب الطالب أو رسب فيما لا يزيد عن مقررين فيسمح له بالتقدم للادتحان الدور الثاني في لئلي
علي الرغم من أن درجة الدكتوراه تمنح في الإعلام التربوي في أحد التخصصين. وللتسجيل لدرجة الدكتوراه في التخصصين يعقد الاعدي امتحان تأهيلي للطالب (شفوي + تحريري) في المجال الذي يتخصص فيه الطالب، والحد الأدنى لمناقشة الدكتوراه سنتين، وسنة لمناقشة الماجستير، ويمنح الطالب درجة الماجستير والدكتوراه بدون تقدير، كما هو موجود بكلية التربية النوعية ببنها، وهذا يختلف عن الكليات المناظرة ، وقد أشار الباحث لهذه المشكلة عند تحليله لبرنامج الإعلام التربوي بينها.

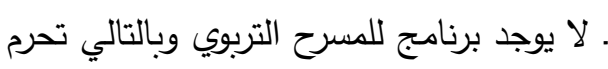
مدن التناة من هذا التخصص في مرحلتي البكالوريوس والدراسات العليا كما في برنامج الإعلام التربوي بالمنيا. . أما عن المشاركين في التدريس للدراسات لتربي بالينا. العليا فيشترك المدرسون والأساتذة المساعدون

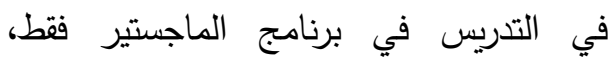
والأساتذة المساعدون والأساتذة في برنامج

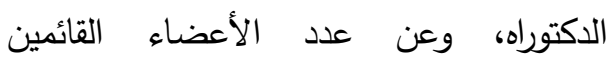
بالتدريس للدراسات العليا والموجودين علي قوة

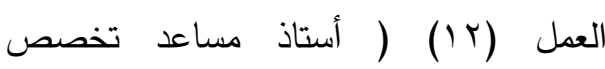
صحافة، + أستاذ مساعد منتدب + (.

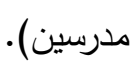
· وبالتالي فإن برنامج الإعلام التربوي بالدراسات العليا بنوعية بورسعيد في حاجة إلي

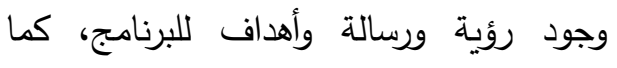


شهر سبتمبر من كل عام، وإذا رسب أو تغيب ويعيد السنة الدراسية دراسة وامتحانا ، فإذا

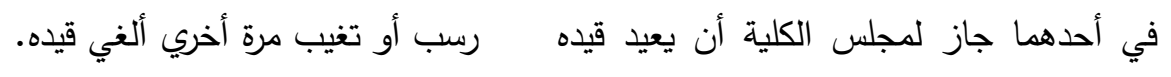

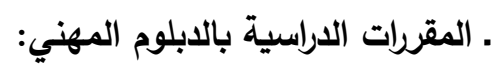

جدول (ץ ؛ ) الساعات التدريسية للابلوم المهنية في الإعلام التربوي

\begin{tabular}{|c|c|c|c|c|c|c|c|c|c|}
\hline \multirow{2}{*}{ الامتحان زمن } & \multicolumn{4}{|c|}{ الارجة } & \multicolumn{3}{|c|}{ الساعات الأسبوعية } & \multirow{2}{*}{ المقررات الدراسية } & \multirow{2}{*}{ p } \\
\hline & مجموع & تحريري & تطبيقي & أعمال سنة & المجموع & تطبيقي & نظري & & \\
\hline$r$ & ๑. & $\varepsilon$ & - & 1. & r & - & r & مناهج البحث في الإعلام & 1 \\
\hline$r$ & o. & $\varepsilon$ & - & 1. & r & - & r & الإحصاء التربوي & r \\
\hline$r$ & 0 . & $\varepsilon$. & - & 1. & $r$ & - & $r$ & الإعلام والتتمية & $r$ \\
\hline$r$ & o. & $\varepsilon$ & - & 1. & $r$ & - & $r$ & الإذاعات الدولية & $\varepsilon$ \\
\hline$r$ & o. & 7. & $r$. & 1. & ؛ & $r$ & $r$ & الكتابة للراديو & 0 \\
\hline$r$ & o. & 7. & r. & 1. & $\varepsilon$ & $r$ & $r$ & الكتابة للتليفزيون & 7 \\
\hline$r$ & o. & $\varepsilon$. & - & 1. & r & - & r & التشريعات الإعلامية & $\mathrm{v}$ \\
\hline$r$ & o. & 7. & $r$. & 1. & $\varepsilon$ & r & $r$ & الصحافة المدرسية & $\wedge$ \\
\hline$r$ & 0 . & $\varepsilon$. & - & 1. & $r$ & - & r & الرأي العام والدعاية & 9 \\
\hline - & ... & - & - & - & $r \varepsilon$ & 1 & 11 & المجموع & \\
\hline
\end{tabular}

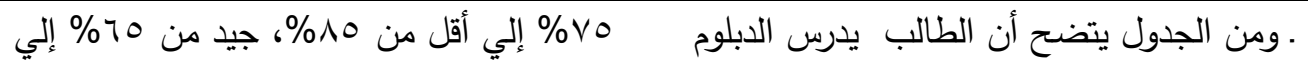

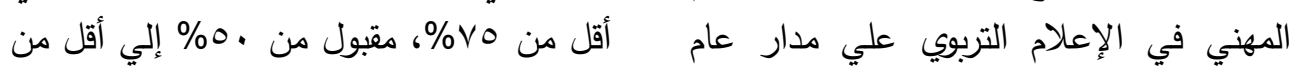

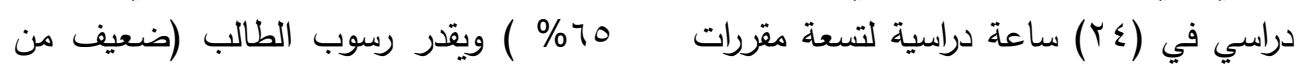

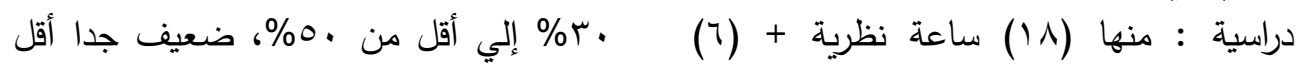

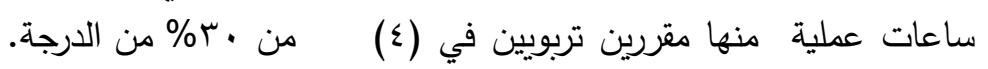

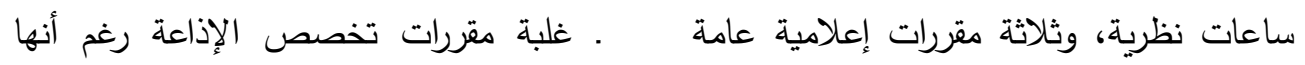

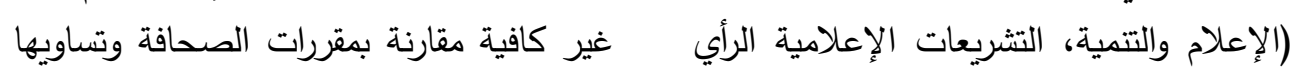

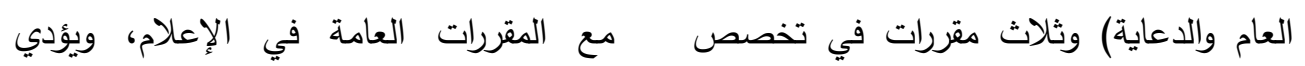

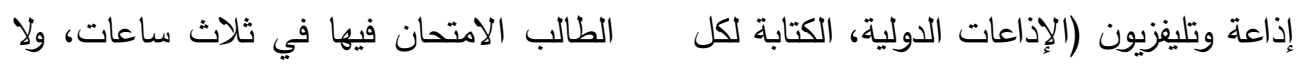

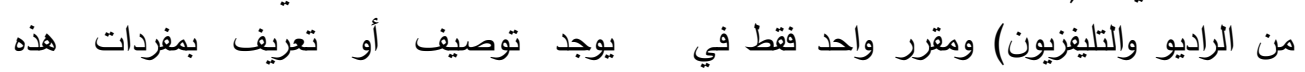
تخصص صحافة مدرسية دون وجود أي المقررات بلائحة الدراسات العليا.

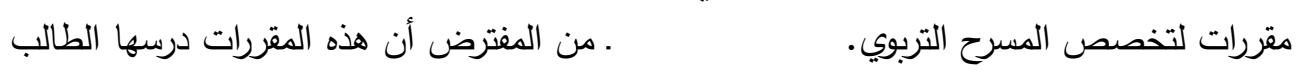

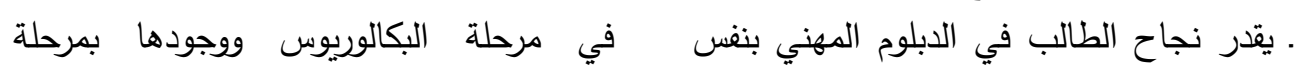
التقديرات المطبقة علي مرحلة البكالوريوس الدراسات العليا هو تكرار لها.

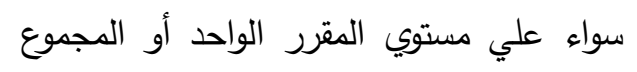

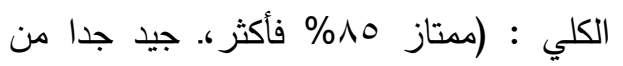


معادلة من معهد علمي معترف باه من المجلس

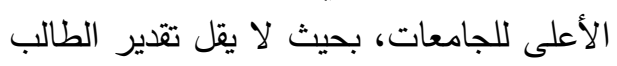

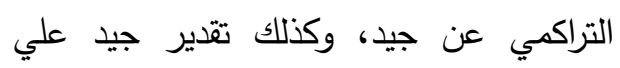
الأقل في مقررات التخصص في في دئ درجة البكالوريوس، مع ضرورة اجتياز امتحان القبول فقرل

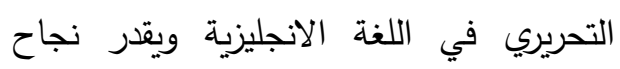

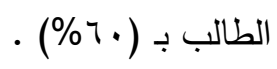

ـ مدة الدراسة ببرنامج الدبلوم الخاص سنتان

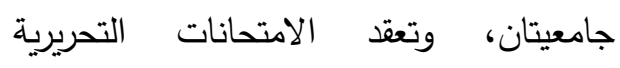
والثفوية والتطبيقية في شهر مايو من كل

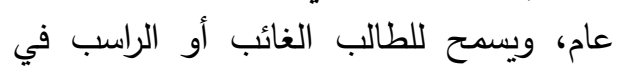

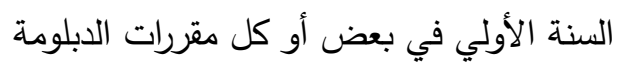

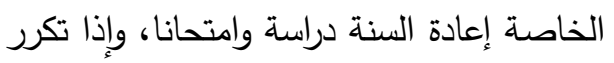

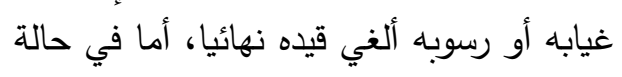
رسوب الطالب في مقررات الفرقة الثانية في أكثر من مقررين فيعيد السنة دراسة وامتحانا،

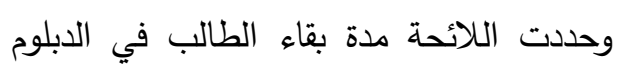
الخاص بألا تزيد عن أربع سنوات.

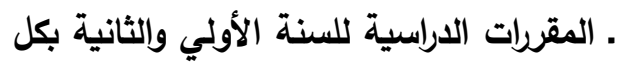
التخصصات بالكلية ومنها تخصص الإعلام

التربوي:

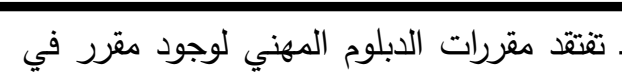

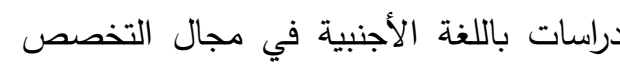
أو مقرر في الترجمة الإعلامية. · وعلي الرغم من نص اللائحة بضرورة

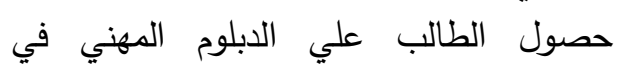
الإعلام التربوي قبل التحاقه بالدبلوم الخاص الطاب الطاب إلا أن الطالب لا يلتحق به ـ فهو غير مفعل وغير مطبق حتى وقت إجراء الدراسة ـ ويتقدم

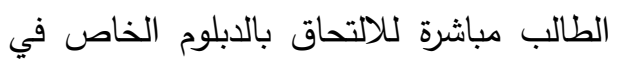

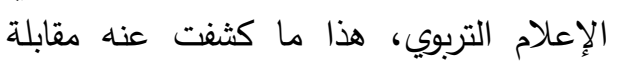

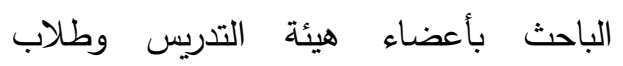

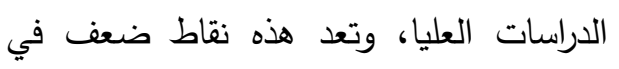
برنامج الدبلوم المهني في الإعلام التربوي تحتاج إلى تحسين وتعديل.

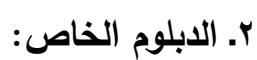
يثترط قيد الطالب بالدبلوم الخاص أن

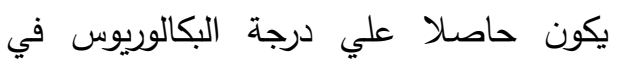
التربية النوعية من إحدى الجامعات المصرية

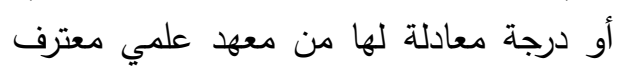
باه، ودرجة الدبلوم المهني في التربية النوعية التهنية من إحدى الجامعات المصرية أو علي درجة التربة لإنية

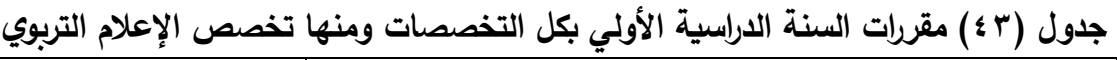

\begin{tabular}{|c|c|c|c|}
\hline \multicolumn{2}{|c|}{ عدد الساعات } & \multirow[t]{2}{*}{ المقررات الدراسية } & \multirow[t]{2}{*}{ s } \\
\hline مجموع & نظري & & \\
\hline$r$ & r & علم النفس التعليمي & 1 \\
\hline$r$ & $r$ & مناهج البحث في مجالات التربية & r \\
\hline$r$ & $r$ & مقرر في اللغة العربية وآدابها & $r$ \\
\hline$r$ & $r$ & مقرر في التخصص باللغة الإنجليزية & $\varepsilon$ \\
\hline$r$ & - & مقرر في تطبيقات مادة التخصص & 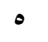 \\
\hline$\varepsilon$ & - & مشروع تطبيقي في التخصص & 1 \\
\hline$r$ & - & مقرر في التخصص (1) & $v$ \\
\hline$r$ & - & مقرر في التخصص (r) & $\wedge$ \\
\hline
\end{tabular}




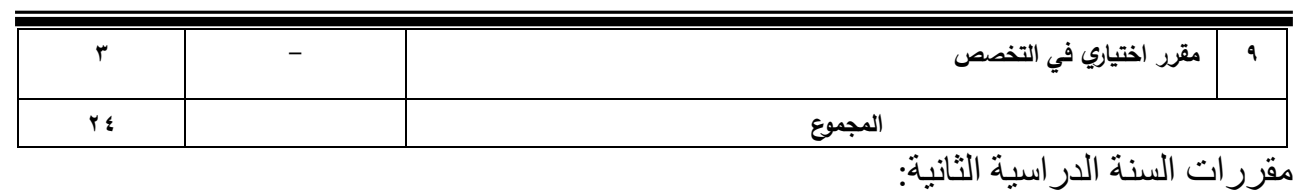

جدول (؛ ؛ ) مقررات السنة الدراسية الثانية بكل التخصصات ومنها تخصص الإعلام التربوي

\begin{tabular}{|c|c|c|c|}
\hline \multicolumn{2}{|c|}{ عدد الساعات } & \multirow[t]{2}{*}{ المقررات الدراسية } & \multirow[t]{2}{*}{ b } \\
\hline مجموع & 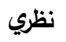 & & \\
\hline r & r & طرق تدريس مادة التخصص & 1 \\
\hline r & r & أصول التربية & $r$ \\
\hline r & r & تكنولوجيا التربية & $r$ \\
\hline r & r & التوجيه التعليمي والإرشاد النفسي & $\varepsilon$ \\
\hline$r$ & $r$ & مصادر المعلومات & - \\
\hline r & $r$ & الإحصاء التربوي & 9 \\
\hline$r$ & - & مقرر في التخصص (1) & $\mathrm{v}$ \\
\hline$r$ & - & مقرر في التخصص (r) باللغة الإنجليزية & $\wedge$ \\
\hline$r$ & - & مقرر اختياري في التخصص & 9 \\
\hline$\varepsilon$ & - & مشروع تطبيقي & 1. \\
\hline ro & & المجموع & \\
\hline
\end{tabular}

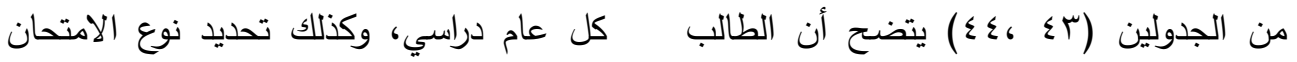

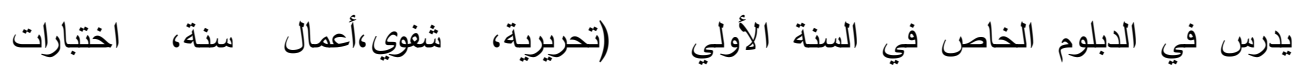

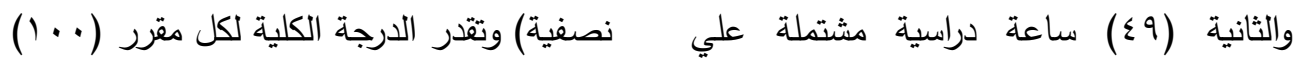

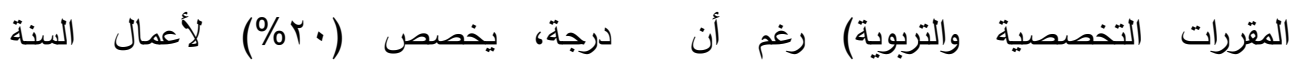

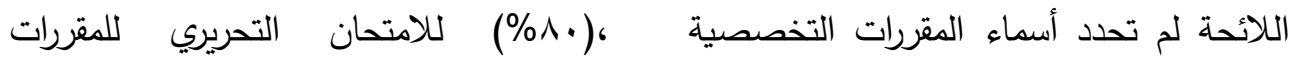

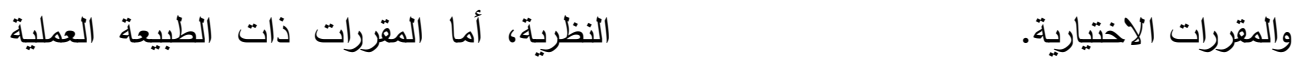

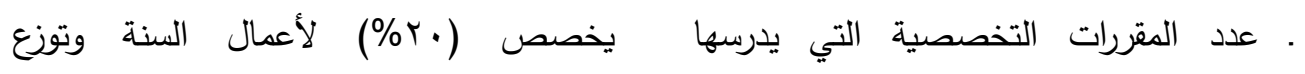

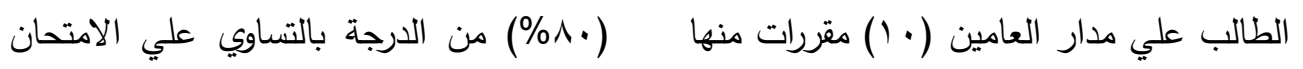

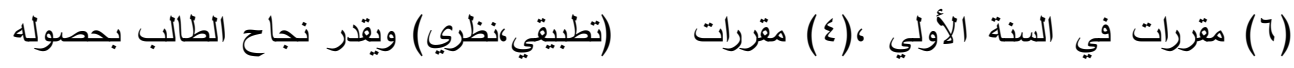

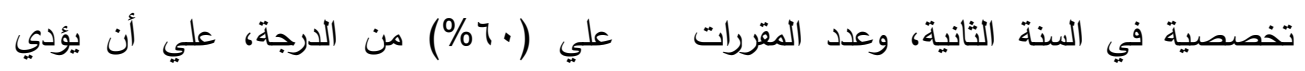

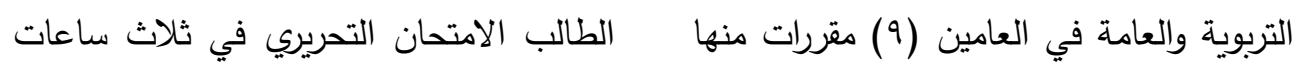
(r) في السنة الأولي + (T) في السنة الثانية. في شهر مايو والتطبيقية قبلها بأسبوع، ويعقد · تركت اللائحة اقتراح مسميات المقررات امتحان في شهر سبتمبر للطلاب الذين تخلفوا

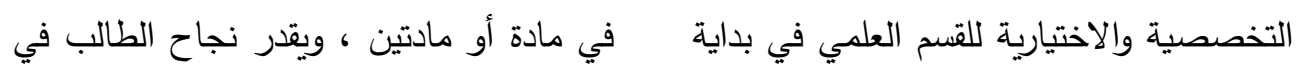


يثترط قيد الطالب للماجستير أن يكون حاصلا علي الدبلوم الخاص في التربية النوعية في تخصص الإعلام التربوي أو علي درجة معادلة لها من معهة علمي معترف باله.

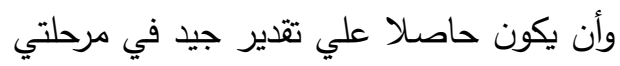
البكالوريوس والدبلوم الخاص، وكذلك مقررات

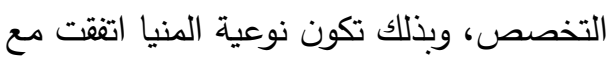
أشمون في تطبيق شرط التقدير في مقررات التخصص، ولكن ليس بتقدير جيد جدا وليس بتقدير جيد. كما أثارت اللائحة ألا يكون قد مضي علي

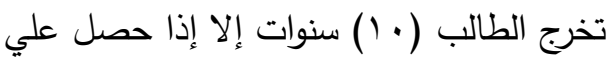
دبلوم الدراسات العليا، وبالتالي فإن الثرال الثرط الأخير يحرم من لله رغبة في الحصول علي درجة الماجستير في الإعلام التربوي، وهذا الشرط يحتاج إلي أعادة النظر فيه حيث الاعليث أنها الكلية الوحيدة في صعيد مصر بها دراسات عليا في مجال الإعلام التربوي.

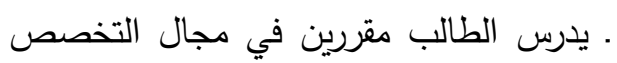

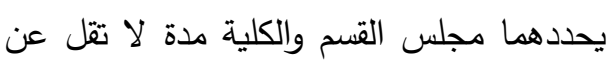
(10) أسبوعا (فصل دراسي) في ثلاث ساعات أسبوعية للمقرر الواحد، بالإضافة لحضور حلقة بحث لمناقثة مشروع بحثه،

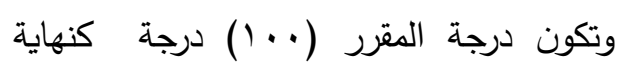

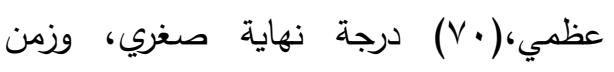
الامتحان ثلاث ساعات، ولا يجوز التسجيل في درجيه موضوع البحث إلا بعد نجاحه في المقررات
المقرر الواحد أو المجموع الكلي (ممتاز من

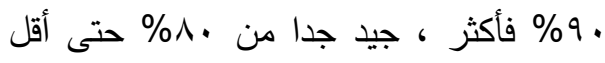

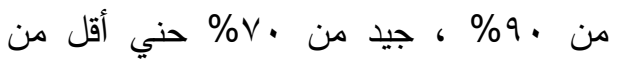

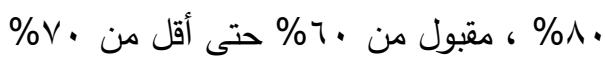

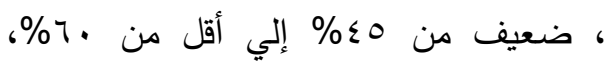
ضعيف جدا أقل من ه؛\%\%)، وهي بذلك تختلف عن تقديرات الدبلوم المهني.

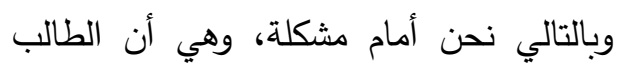

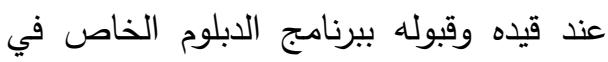
الإعلام التربوي سواء كان من المصريين أو

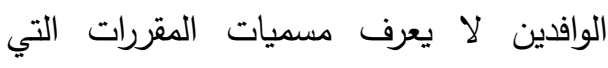

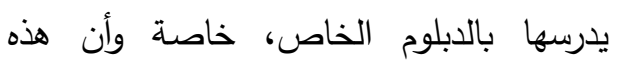
المقررات غير متاحة علي الموقع الالكتروني

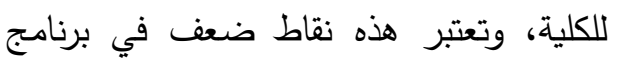
الدبلوم الخاص والمهني تحتاج إلي تحسين.

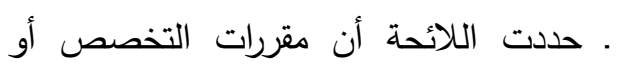
المقرر الاختياري في التخصص من ساعات

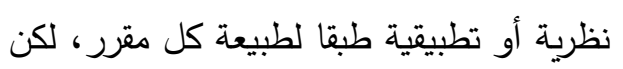
لا يوجد تعريف أو توصيف لهذه المقررات باللائحة أو الموقع الاككتروني للكلية.

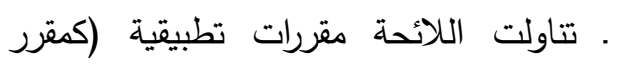
تطبيقات مادة التخصص، مشروع تطبيقي في التخصص) للفرقة الأولي والثانية، كما حرصت علي وجود مقررين باللغة الأجنبية في السنة الأولي والثانية وهذه نقاط قوة في برنامج الدبلوم

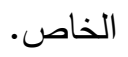

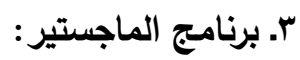


يشترط قيد الطالب للبرنامج أن يكون

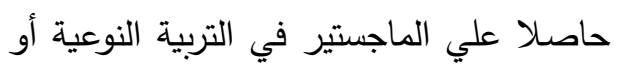
درجة معادلة لها من معهد علمي معترف به من الجامعة ، ويدرس الطالب بعد قيده مقررين

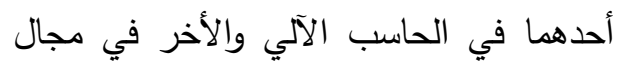

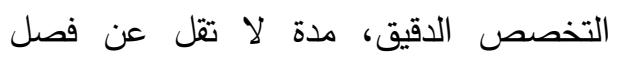
دراسي واحد، في ثلاث ساعات أسبوعية

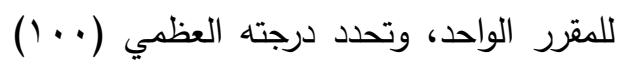

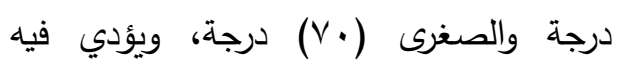
امتحانا ثلاث ساعات يحدد مجلس الكلية ميعاد الامتحان، ولا يجوز لله تسجيل موضوع رسالته إلا بعد نجاحه فيها وهذا عكس ما يحدث في لاهي بعض الكليات المناظرة كالمنصورة ودمياط وأشمون التي اعتبرت دراسة الدقررات والنجاح فيها شرطا للمناقثة وليس للتسجيل، وتحسب دربن درجة النجاح من حصول الطالب علي

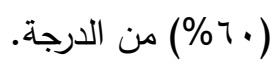

. حددت اللائحة إلغاء قيد الطالب للماجستير ل

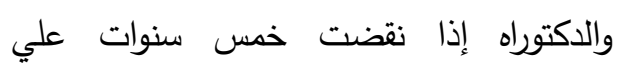
تسجيله إلا إذا رأي مجلس الكلية الإبقاء علي

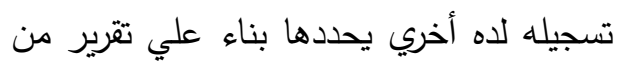
المشرف وبحد أقصي عامين وقد اتفتت لوائح الكليات المناظرة في ذلك. وبالتالي فإن برنامج الإعلام التربوي

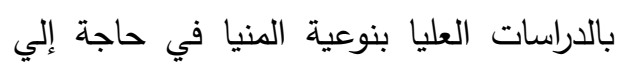
تحسين وتطوير رؤية ورسالة البرنامج، كما يحتاج لتحديد أهدافه وتحسين مقرراته وساعات وتئ ورئات
الدراسية، وهذا يختلف عن الكليات المناظرة التي اعتبرت نجاح الطالب في مقررات الماجستير شرط للمناقثة وليس شرط للتسجيل. • بعد مضي عام علي الأقل من تاريخ تسجيل

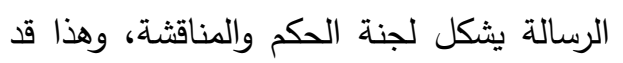
يؤدي إلي تسرع الطلاب في إعداد رسائلهم دون الاهتمام بجودة البحث العلمي ووجود الكثير من الأخطاء العلمية والمنهجية في لإنيات الرسائل العلمية. • حددت اللائحة أيضا حالة الطلاب الوافدين فيما يخص قبول الرسالة للمناقثة، أن يكون

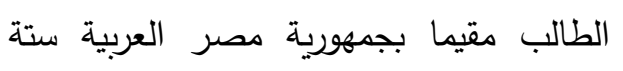
أثهر علي الأقل خلال فترة البحث، وأن يحضر قاعات البحث في القسم لمدة ستة شهور علي الأقل من تاريخ موافقة مجلس الكلية علي التسجيل للماجستير والدكتوراه معا،

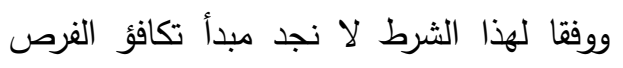
عند مناقثة الرسالة خلال عام من التسجيل حال قيام الطالب الوافد بتطبيق دراسته في البلد

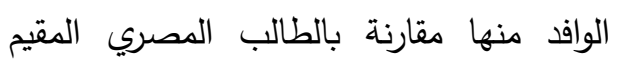
بمصر، علي الرغم من أن هذا الثرط ميز

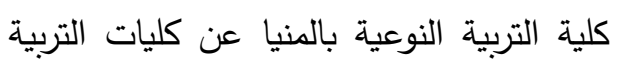

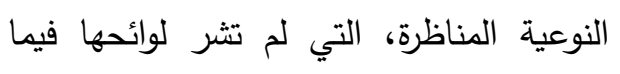

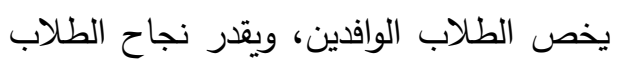
(ممتاز ، جيد جدا، جيد، مقبول).

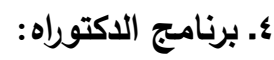


تدريسها مع وجود إستراتيجية للتعليم والتعلم، والأهمية النسبية للمتوسط، واختبار (كا؟)

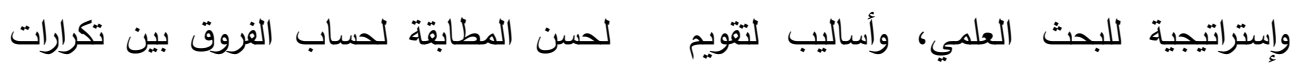

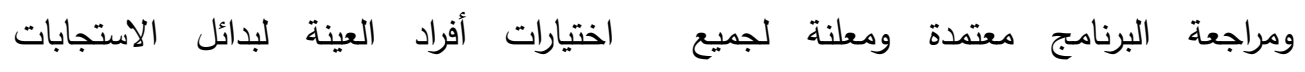

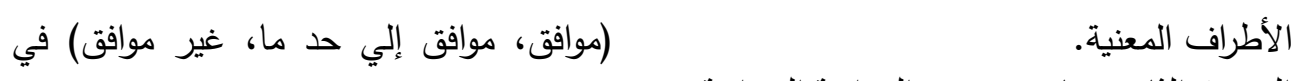

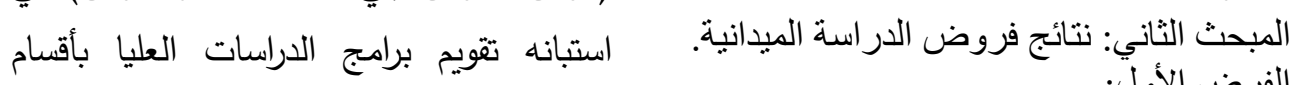

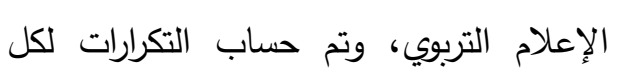

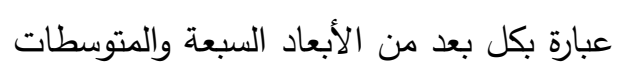

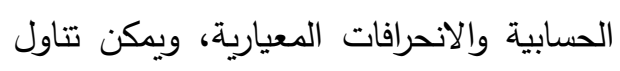
النتائج كما يتضح بالجداول التالية: البعد الأول: برنامج الدراسات بالجات العليا وأهدافه التهالئ

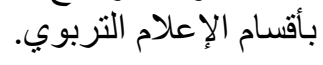
الفرض الأول: توجد فروق ذات دلالة إحصائية بين تكرارات

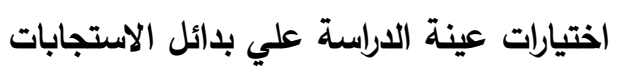
(موافق، موافق إلي حد ما، غير موافق) في استبانه تقويم برامج الاراسات العليا بأقسام الإعلام التربوي.

للتحقق من صحة هذا الفرض استخدم الإعلامبوي الباحث المتوسط الحسابي والانحراف المعياري

جدول(0 ؛ ) التكرارات والمتوسطات الحسابية والانحرافات المعيارية ومربع كا؟ للفروق بين بدائل

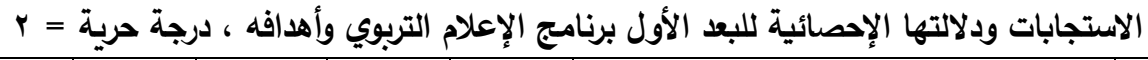

\begin{tabular}{|c|c|c|c|c|c|c|c|c|c|c|c|c|c|}
\hline \multirow{3}{*}{ 需 } & \multirow[t]{3}{*}{ الدلالة } & \multirow[t]{3}{*}{ مربع كا" } & \multirow{3}{*}{ للمتوسطبة الأهمية } & \multirow{3}{*}{ المعياري } & \multirow[t]{3}{*}{ المتوسط } & \multicolumn{6}{|c|}{ بدائل الاختيارات } & \multirow[t]{3}{*}{ p } & \multirow{3}{*}{$\underline{\underline{E}}$} \\
\hline & & & & & & \multicolumn{2}{|c|}{ غير موافق } & \multicolumn{2}{|c|}{ إلي حد ما } & \multicolumn{2}{|c|}{ موافق } & & \\
\hline & & & & & & $\%$ & s & $\%$ & 5 & $\%$ & 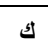 & & \\
\hline ir & $\cdot, \cdots r$ & $11,71 \leqslant$ & 59.47 & אדוג,י & $1, \vee \wedge \varepsilon$ & $0 \cdot, \cdot$ & « & $r 1, r$ & 19 & $r \wedge, \varepsilon$ & ro & 1 & \\
\hline 1 &,$\ldots$, & QV, QTr & 92.40 & $\cdot, 0 \leqslant$. & r,VYr & $\bullet, v$ & • & $11, \varepsilon$ & 1. & Ar & $V_{r}$ & r & \\
\hline 7 & $\cdots, \ldots r$ & $|r, . q|$ & 73.47 & $\cdot$, AVr & $r, r, \xi$ & $r 9,0$ & Y & $r \cdot, 0$ & 11 & o. & ؛ & $r$ & \\
\hline - & $\cdot, .00$ & $0, \wedge \backslash \wedge$ & 72.70 & •, Arv & $r,|\wedge|$ & $r v, r$ & $Y \varepsilon$ & $r v, r$ & $r \xi$ & $\{0,0$ & $\varepsilon$. & $\varepsilon$ & \\
\hline$\wedge$ &,$\ldots$, & $r T, 0 \leq 0$ & 70.43 & ., 90. & $r, 11 T$ & 10,9 & $1 \varepsilon$ & $04, \wedge$ & o. & $r v, r$ & $r \varepsilon$ & 0 & $\frac{10}{5}$ \\
\hline$r$ &,$\ldots 1$ & $|v, T| \varepsilon$ & 76.13 & $\cdot$, TVV & $r, Y \wedge \varepsilon$ & $1 \%, 0$ & 11 & $\leq 4,7$ & $\leqslant 1$ & $\varepsilon \cdot, q$ & 4 & 7 & 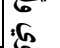 \\
\hline ir &,$\ldots$, & IT,VTV & 56.03 & • & 1,711 & $\varepsilon v, v$ & $\varepsilon r$ & $r_{4, \varepsilon}$ & rr & 10,9 & $1 \leqslant$ & $v$ & 宸 \\
\hline - & •, ror & $r, \cdot ४ \wedge$ & 62.87 & - V१ & 1, & $r v, 0$ & rT & ץ ४, & rr & $r, 1$ & r & $\wedge$ & そ̌ \\
\hline 0 & $\cdot, .1 \varepsilon$ & $\Lambda, \varepsilon \vee \vee$ & 74.60 & $\cdot, A 14$ & r,YrA & $r r, q$ & $r_{1}$ & $Y \wedge, \varepsilon$ & ro & $\leq \vee, V$ & $\leqslant r$ & 9 & \\
\hline- & -, Err & 1,VYV & 64.37 & $\cdot, \vee \wedge \wedge$ & 1,941 & $r \leqslant, 1$ & r. & $r \wedge, \tau$ & & $r v, r$ & Y $\varepsilon$ & 1. & 5. \\
\hline- & $\cdot, r \leqslant \leqslant$ & $r, \wedge \backslash A$ & 71.20 & •, $\vee$ ৭. & r,ITY & ro & YY & rq, \& & rr & $r \Lambda, \tau$ & צ & 11 & \\
\hline$v$ &,$\ldots$, & 1 IT, ז人 & 72.33 &., 791 & r,iv. & iv & 10 & $\varepsilon \wedge, q$ & $\leq r$ & $r \varepsilon, 1$ & $r$. & ir & \\
\hline- & ., QY & $\cdot, 109$ & 67.03 & $\cdot, \wedge .9$ & $r, .11$ & $r 1, \Lambda$ & YA & $r_{0, r}$ & r & rr & ra & ir & \\
\hline 1. &,$\ldots \varepsilon$ & $11, r \vee \mu$ & 68.17 & $\cdot, v \cdot q$ & $r, . \leqslant 0$ & $r r, V$ & $r$. & o. & ؛ & $r v, r$ & Y $\varepsilon$ & $1 \varepsilon$ & \\
\hline
\end{tabular}




\begin{tabular}{|c|c|c|c|c|c|c|c|c|c|c|c|c|}
\hline ؛ & $\cdots, \ldots \wedge$ & $9, v, 0$ & 75.37 & ., > 0 . & r,YTl & $1 \wedge, r$ & 19 & $r v, 0$ & rr & & ra & 10 \\
\hline r & 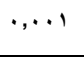 & $1\{, .71$ & 76.87 & -, V & $r, r \cdot \varphi$ & $1 \varepsilon, 1$ & 14 & $r q, \wedge$ & ro & $\leq 0,0$ & $\varepsilon$. & 14 \\
\hline 11 & ${ }^{\prime}, \ldots \varepsilon$ & $11,+41$ & 66.73 & .,, 1 . & $r, \ldots r$ & $r \mu, q$ & ri & o. & ๕ & Yq, 1 & r & iv \\
\hline 1. & , , & $\Lambda, \varepsilon \vee \vee$ & 68.17 & - vro & $r, \cdot \leqslant 0$ & $r r, q$ & ri & $\varepsilon v, V$ & $\varepsilon r$ & $r \wedge, \varepsilon$ & ro & 11 \\
\hline 9 & r & $8,9,9$ & 69.67 & •, VTV & $r, . q$. & $r Y, Y$ & $r$. & $\varepsilon 0,0$ & $\varepsilon$. & r & rA & 19 \\
\hline
\end{tabular}

rا ـ يعلن عن الأهداف من خـلال (الموقع

لالكتروني للكلية، لوحات، دليل ، مطويات). ع ا ـ تراعي الأهداف مهارات خريجي الإعلام

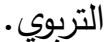

IV ت تثجع الأهداف الباحثين علي الابتكار

والإبداع.

1 ا ـ تواكب الأهداف الجديد في مجال الإعلام

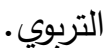

19

التدريبيـة فـي المجـالات الصـحفية والإذاعيـة والمسرحية.

حيث جاءت كا؟ دالة إحصـائية عند مستوي دلالـة (1 (,. . . .,.•)، وهذا يعني أن معظم أفراد العينـة (موافقون، وموافقون إلى حد مـا)

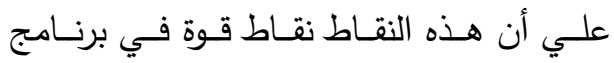
الإعلام التربوي. ـ وجـدت أيضــا فـروق ذات دلاعـــة إحصـائية لصالح الاختيار غير موافق في العبارتين: ا ـ يوجد برنـامج دراسـات عليـا بقسم الإعـلام التربوي وفقا لمعايير الجودة.

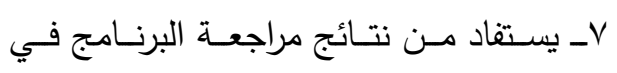
تطويره.
من نتائج الجدول السـابق يتضـح وجـود فـروق ذات دلالـــة إحصــائية بـين تكـرارات

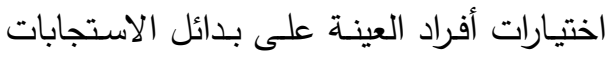

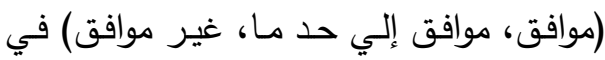
تقيـيمهم اللبعد الأول: برنـامج الدراسـات العليـا

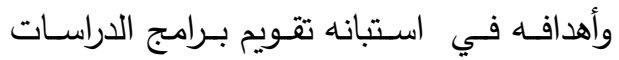
العليا بأقسام الإعلام التربوي، لصالح الاختيار موافق في العبارات الخمسة الآتية: r. توجد رؤية ورسالة للبرنامج.

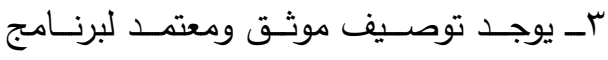
الإعلام التربوي.

9 و ـ تبنــي الأهــاف علـي التحليـل البيئـي والتحديات الحالية والمستتبلية. 10 للباحثين في مجال الإعلام.

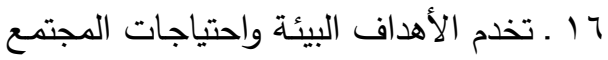

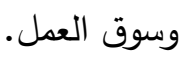
ـ وجدت فروق دالة إحصائية لصالح الاختيار موافق إلي حد ما في العبارات السبعة الآتية: ه ـ مدة الدراسة بالبرنامج مناسبة وكافية. 7 ـ ـ تراجـع محتويـات البرنـامج مـن مـراجعين خارجيين. 
الحسابية والنسب المئوية لهم في هذه العبارات، وجاءت كا؟ غير دالة إحصائية. وبصفة عامة فإن برنامج الإعلام التربوي بكليات التربية النوعية يحتاج إلي: تحديد

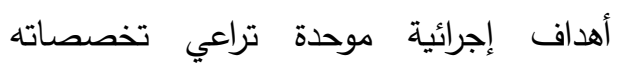
الاقيقة، ويشارك في وضعها كافة الأطراف المعنية، ويتضمن مقررات تخصصية كافية

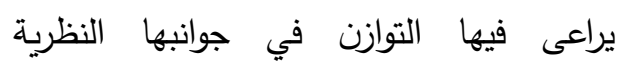
والتطبيقية وساعات تدريسها مستوي(الدبلوم، الماجستير، الدكتوراه). ـ واعتمادا علي المتوسطات الحسابية للعبارات وترتيبها، نجد أن العبارة (r) توجد رؤية ورسالة للبرنامج جاءت في الترتيب الأول، ثخ العبارة (7 (1) تخدم الأهداف البيئة واحتياجات سوق العمل في الترتيب الثاني، ثم العبارة (†) تراجع محتويات البرنامج من مراجعين خارجين

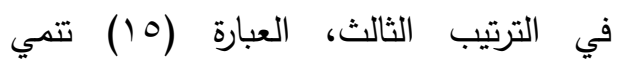
الأهداف مهارات البحث العلمي للباحثين في لتي

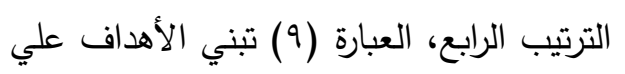
التحليل البيئي في الترتيب الخامس، والعبارة (r) يوجد توصيف موثق ومعتمد للبرنامج في

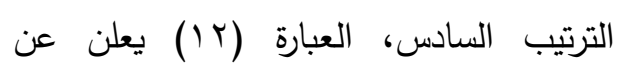
الأهداف من خلال موقع الكلية في الترتيب السابع، والعبارة (0) مدي كفاية مدة الدراسة بالبرنامج في الترتيب الثامن، والعبارة (9) تلبية الأهداف لاحتياجات الباحثين في الترتيب

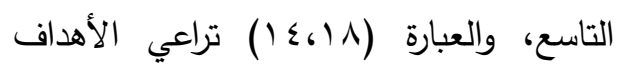

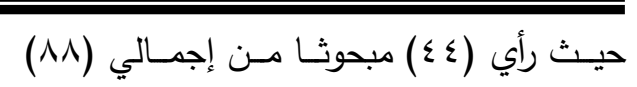

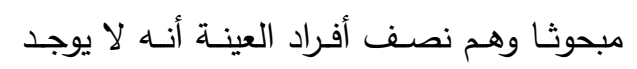
برنـامج للدراسـات العليا في ضدوء الجودة فهم

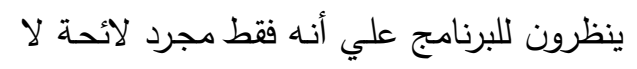

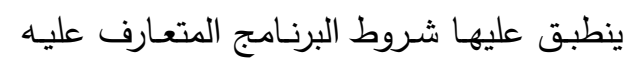

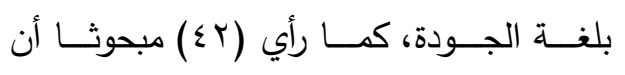

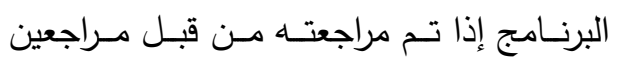
داخليين أو خارجيين لا يستفاد من نتائج هذه

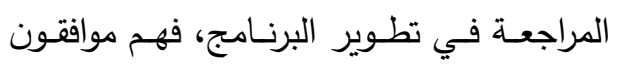
علي أن هذه النقاط هي نقاط ضعنف ما زالت تحتاج إلي تحسين. - لا توجـد فـروق ذات دلاتــة إحصــائية بـين

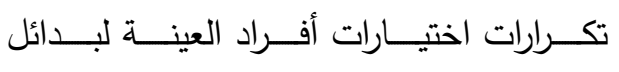

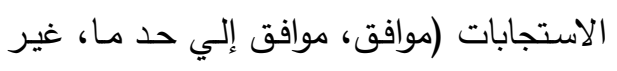
موافق) في العبارات الخمس الآتية : كـ يحتوي البرنـامج علـي مقررات تخصصية كافية. ^ـ توجد أهداف للبرنـامج تراعي تخصصـات الإعلام التربوي. • اــ تحقـق الأهـداف رؤيـة ورسـالة البرنـامج والكلية. 11 - ـيثـارك فـي وضــع الأهــاف الأطــاف المعنية داخل وخارج المؤسسة. ب ا. الأهداف إجرائية وقابلة للتحقيق والقياس.

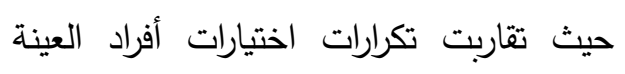

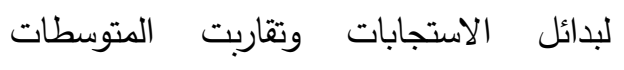


الثاني عشر، ثم العبارة (V) يستفاد من نتائج مهارات الخريجين، مواكبة الأهداف للجديد في مراجعة البرنامج في تطويره في الترتيب الثالث

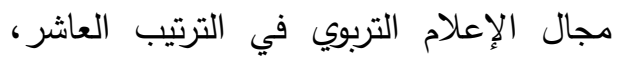

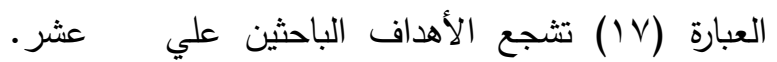

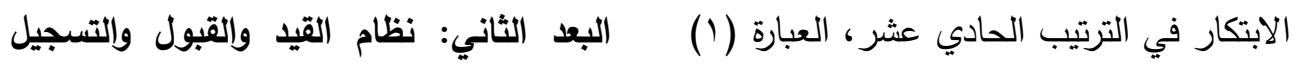
يوجد برنامج للدراسات العليا في الإعلام بالدراسات العليا. التربوي يراعي معايير الجودة في الترتيب

جدول († §) التكرارات والمتوسطات الحسابية والانحرافات المعيارية ومربع كا` للفروق بين بائل

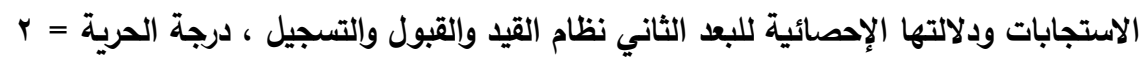

\begin{tabular}{|c|c|c|c|c|c|c|c|c|c|c|c|c|c|}
\hline \multirow{3}{*}{ يب الترت } & \multirow{3}{*}{ الالالة } & \multirow{3}{*}{ مربع كا" } & \multirow{3}{*}{ اللمتوسط ألمبية } & \multirow{3}{*}{ المعياري } & \multirow{3}{*}{ المتوسط } & \multicolumn{6}{|c|}{ بدائل الاختيارات } & \multirow[t]{3}{*}{ م } & \multirow[t]{3}{*}{ البعد } \\
\hline & & & & & & \multicolumn{2}{|c|}{ غير موافق } & \multicolumn{2}{|c|}{ إلي حذ ما } & \multicolumn{2}{|c|}{ موافق } & & \\
\hline & & & & & & $\%$ & S & $\%$ & S & $\%$ & s & & \\
\hline - & . $10 \mathrm{~V}$ & $\cdot, \wedge \leqslant 1$ & 67.80 & •, $\vee 9 \&$ & $r, \cdot r \xi$ & $r 9,0$ & ry & $r v, 0$ & rr & $r T$ & ra & 1 & \\
\hline 1 & 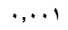 & Y9, & 88.63 & . & r, 109 & 9,1 & $\wedge$ & 10,9 & $1 \varepsilon$ & vo & 74 & $r$ & \\
\hline$r$ & ., , & $11, r \vee r$ & 74.23 & , , 0 \& & Y,YYV & $r v, r$ & $r \xi$ & $r Y, Y$ & r. & 0. & $\leqslant$ & $r$ & \\
\hline 。 & -,. $\times 9$ & $v, 11 \varepsilon$ & 67.80 & •, VN & $r, \cdot r \varepsilon$ & ro & rr & $\leqslant 4,4$ & \&1 & $\lceil\Lambda, \xi$ & ro & 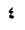 & \\
\hline$r$ & $\cdot, \ldots 1$ & $T \leqslant, O Y T$ & 75.00 & .,094 & r, YO. & $\wedge$ & $\mathrm{v}$ & 09,1 & or & $r \mu$ & ra & - & \\
\hline - & P & 1,OrT & 70.07 & $\cdot, \Lambda, r$ & $r, 1, r$ & $r v, r$ & $r \xi$ & $r 0, r$ & $r$ & $r v, 0$ & rr & 1 & \\
\hline 9 &.,$\ldots 1$ & ०Y, & 50.37 & דו, & 1,011 & $19, r$ & 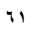 & $1 ., r$ & 9 & $r, 0$ & 11 & $v$ & \\
\hline v & $\cdot, \ldots 1$ & $r \cdot, \wedge \backslash \wedge$ & 62.87 & - 949 & 1,^^५ & o. & 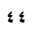 & $11, \xi$ & 1. & $r \Lambda, \tau$ & $r \varepsilon$ & $\wedge$ & \\
\hline - & - rov & $\cdot, \wedge \leqslant 1$ & 68.17 & •, ^ $\leqslant r$ & $r, . \leqslant 0$ & rr & ra & $r q, 0$ & Y & $r v, 0$ & rr & 9 & \\
\hline ؛ & $\cdots, \ldots v$ & $9,9 \vee \mathrm{V}$ & 68.53 & $\cdot, \times 14$ & $r, .04$ & $r Y, Y$ & $r$. & $\leqslant \wedge, q$ & $\leqslant r$ & $\uparrow_{\Lambda, \xi}$ & ro & 1 & والت \\
\hline 1 & .,. r. & v, vav & 66.27 & $\cdot, 9 \cdot 4$ & $1,9 \wedge 1$ & $\varepsilon, q$ & ry & $19, r$ & iv & $\Gamma 9, \wedge$ & ro & 1 & يل \\
\hline$r$ &,$\ldots$ & 1.,ORT & 75.00 & , & r, ro. & iv & 10 & $\leq \cdot, q$ & ry & $\leqslant r$ & rv & 1 & \\
\hline - & D,YYI & $r, \cdot r \mu$ & 67.03 & •, vis & $r,+11$ & $\lceil\wedge, \xi$ & ro & $\leqslant r$ & $r v$ & $r 9,0$ & r & $r$ & \\
\hline$\wedge$ & -, , rr & $\curlyvee, \wedge \leqslant 1$ & 59.47 & •, Vฯ & $1, \vee \wedge \varepsilon$ & $\varepsilon r$ & rv & $r v, 0$ & rr & $r ., 0$ & 14 & $\varepsilon$ & \\
\hline
\end{tabular}

من نتائج الجدول السـابق يتضـح وجود اختيارات أفراد العينـة علي بـدائل الاستجابات

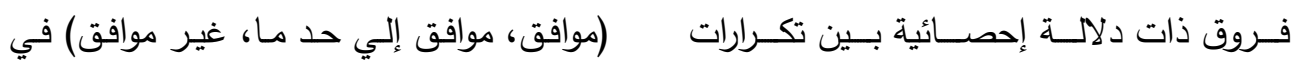


V- يقتصـر الالتحـاق بالدراسـات العليـا علـي طلاب الإعلام التربوي فقط.

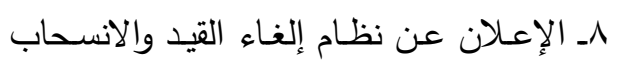
والتحويل للباحثين ا ا. تراعي إدارة الكلية ظروف عمل الباحثين. ع اــــــتبط الاختبــارات التمهيديـــة للقبــول بتخصصات الإعلام التربوي. حيث جاءت كا`ّ دالة إحصـائية وذلك بتكرارات

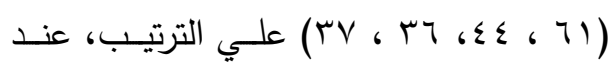
مستوي دلالة (1 . . •)، وهذا يعني أنهم متفقون

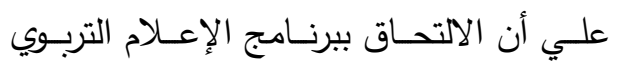
يقتصر علي الطلاب تخصص الإعلام التربوي

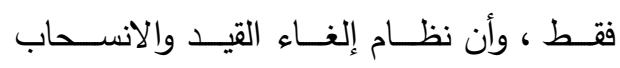

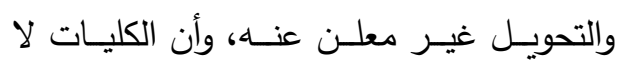
تراعي ظروف عمل الباحثين، وأن الاختبارات التمهيدية للقبول لا ترتبط بالتخصصسات الدقيقة

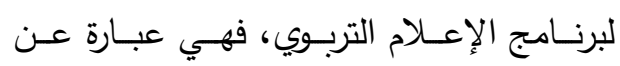

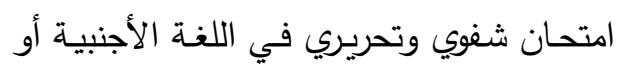
الترجمة الإعلامية.

وهذه النتيجة تتفق تماما مع لوائح كليات التربية

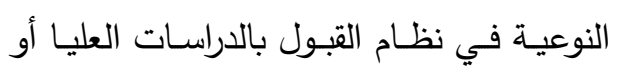

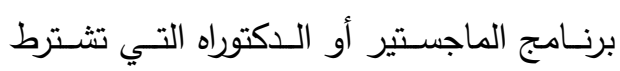
حصــول الطالـب علــي بكـالوريوس التربيــة النوعيـة في الإعـلام التربـوي أو مـا يعادلها إذا كان الطالب يلتحق بالدبلوم الخاص أو متقدم

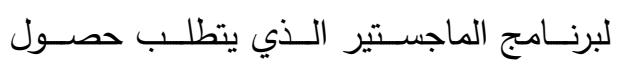

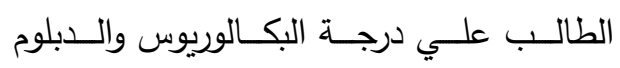

تقيـيمهم للبعـد الثـاني: نظـام القبـول والقيــد والتسـجيل بالدراسـات العليـا في اسـتبانه تقـويم برامج الدراسـات العليا بأقسام الإعلام التربوي، لصـالح الاختيار (موافق) في العبارات الثلاثة الآتية: r- يوجد دليل إشـادي يساعد في عملية القيد والتسجيل والإشراف. عـ تتصف إجراءات القيد والتسـجيل بالبرنـامج

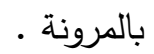

Y ا ـ توجـد قواعـد منظمــة ومعلنـة للبـاحثين الوافدين. - وجدت فروق دالة إحصـائية لصـالح الاختيار (موافق إلي حد ما) في العبارات الثلاثة الآتية:

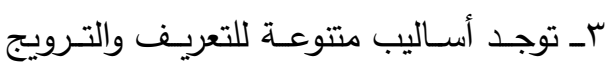
لبرنامج الإعلام التربوي. 0. يوجد تحديث لإجراءات القيد والتسجيل . • ـ ـ تــوفر قاعـدة بيانـات بأعـداد الـدبلومات والدرجات العلمية الممنوحة. حيث جاءت كاب دالـة إحصـائية عند مستوي دلالة (1 (., . . . . •)، وهذا يعني أن معظم أفراد العينة (موافقين، موافقين إلي حد ما) علي أن هذه النقـاط هـي نقـاط قوة في نظـام القيد والقبول والتسجيل بأقسام الإعلام التربوي يجب دعمها. - وجدت فـروق ذات دلالــة إحصـائية لصـالح الاختيـار (غيـر موافق) في العبـارات الأربعـة الآتية: 
يتتاسب مع مستوي الخدمة المقدمة للباحثين التي تقتصر في الغالب علي المحاضرات النظرية، بالإضافة إلى وجود مشكلة كبيرة متمثلة في عدم وجود تحليل لتتاقص أعداد الباحثين ببرامج الإعلام التربوي مقارنة بمرحلة البكالوريوس.

ـ واعتمادا علي المتوسطات الحسابية للعبارات وترتيبها، نجد أن العبارة (Y) يوجد دليل إرشادي يساعد الطلاب في عملية القيد والتسجيل جاءت في الترتيب الأول، ثم العبارة (0) يوجد تحديث لإجراءات القيد والتسجيل في الترتيب الثاني، ثم العبارة (ץ) توجد أساليب متتوعة للتعريف والترويج لبرنامج الإعلام التربوي في الترتيب الثالث،العبارة (• (1) تتوافر قاعدة بيانات بأعداد الدبلومات والدرجات العلمية الممنوحة في الترتيب الرابع،العبارة (ع) باتيات تتصف إجراءات القيد والتسجيل بالبرنامج بالمرونة في الترتيب الخامس، والعبارة (1) تراعي الكلية والقسم ظروف عمل الباحثين في الترتيب السادس، العبارة(^) نظام إلغاء القيد

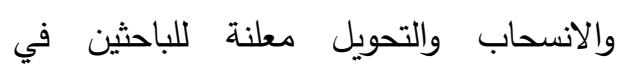

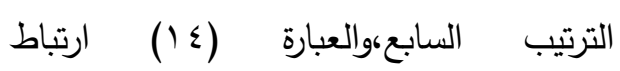
الاختبارات التمهيدية للقبول بالدراسات العليا بتخصصات الإعلام التربوي في الترتيب

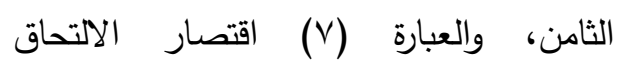
بالدراسات العليا علي طلاب الإعلام التربوي فقط في الترتيب التاسع.
الخـاص في التربيـة النوعيـة، وحصـوله علي درجـة الماجستير في التربيـة النوعيـة إذا كـان الطالب متقدما لدرجة الدكتوراه، وهذه من نقاط الضـف التي ما زالت في حاجة إلي تحسين مستمر - مصع

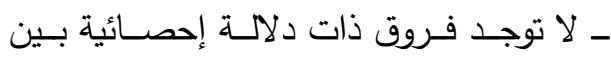

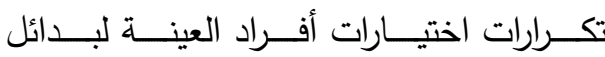
الاستجابات (موافق، موافق إلي حد ما، غير موافق) في العبارات الأربعة الآتية:

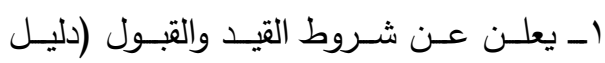
الطالب،الموقع الالكتروني). 7. تتم إجراءات التسجيل بشكل الكتروني. 9ـ تتناسب المصروفات الدراسية مـع الخدمات لهرات الدراسية المقدمة للباحثين. با ا. يوجد تحليل لتزايد وتتاقص أعداد الباحثين بالبرنامج. حيـث تقاربـت تكرارات اختيـارات أفـراد العينـة لبـدائل الاسـتجابات وتقاربــــ النسـب المئويــة

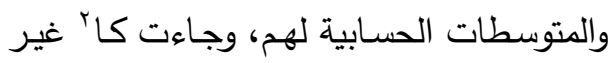
دالة إحصائية . ومن الواضح أن شروط القيد والتسجيل ببعض كليات التربية النوعية غير معلن عنه من خلال دليل ورقي أو الكتروني للطلاب، لونية ولكن معلن عنه من خلال اللوائح بموقع الكلية الالكتروني، كما لا يتم التقديم بشكل الكتروني،

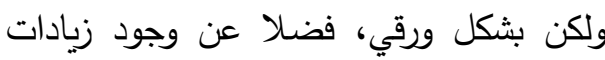

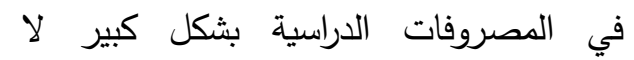


البعد الثالث: المقرر ات الدر اسية.

جدول (\&V) التكرارات والمتوسطات الحسابية والانحرافات المعيارية ومربع كاب للفروق بين بدائل

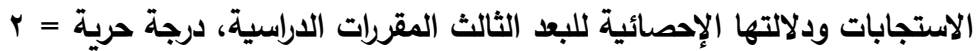

\begin{tabular}{|c|c|c|c|c|c|c|c|c|c|c|c|c|c|}
\hline \multirow{3}{*}{ 䒫 } & \multirow{3}{*}{$\begin{array}{l}\text { 定 } \\
\underline{\underline{E}}\end{array}$} & \multirow{3}{*}{$\underset{\mathfrak{r}}{\mathfrak{r}}$} & \multirow{3}{*}{$\begin{array}{c}\text { للمتوسطبية } \\
\text { الألهمية }\end{array}$} & \multirow{3}{*}{ الانعراف } & \multirow{3}{*}{ المتوسط } & \multicolumn{6}{|c|}{ بائل الاختيارات } & \multirow{3}{*}{ p } & \multirow{3}{*}{$\underline{E}$} \\
\hline & & & & & & \multicolumn{2}{|c|}{ غير موافق } & \multicolumn{2}{|c|}{ إلي حـ ما } & \multicolumn{2}{|c|}{ موافق } & & \\
\hline & & & & & & $\%$ & 5 & $\%$ & s & $\%$ & ك5 & & \\
\hline 1 & $\cdot, .17$ & $\Lambda$, YVY & 75.00 & $\cdot, \vee \vee \vee ४$ & $r, r o$. & $r \cdot, \theta$ & 11 & $r \leqslant, 1$ & $r$. & $\{0,0$ & $\varepsilon$. & 1 & \\
\hline r &,,$\ldots 1$ & $r \cdot, r q 0$ & 80.30 &., 099 & $r, \varepsilon, q$ & $0, v$ & • & $\varepsilon v, v$ & $\leqslant r$ & \& ४ & \&1 & $r$ & \\
\hline - & \& & $\varepsilon, V T V$ & 72.70 & •, VAI & $r,|\wedge|$ & YY,V & r. & r४, \& & rr & $\{\cdot, q$ & rq & $r$ & \\
\hline$\wedge$ &., .11 & $9, .91$ & 74.23 & $\cdot, \mathrm{V} \mu \wedge$ & r,YYV & $1 \Lambda, r$ & 19 & $\{, q$ & Tr & $\{\cdot, q$ & ry & $\varepsilon$ & \\
\hline 1 & $\cdot, \ldots 9$ & $9, \Gamma 4 \leq$ & 75.00 & $\cdot, v \leqslant 4$ & r, ro. & $1 \wedge, r$ & 19 & rی,ч & ع & $\varepsilon r, r$ & rA & 。 & \\
\hline 1. &,$\ldots 1$ & $|\wedge, \wedge \leqslant|$ & 71.57 & . & $r, 1 \leqslant V$ & 10,9 & $1 \varepsilon$ & s & $\leqslant V$ & $r \cdot, v$ & TV & 1 & \\
\hline 1 &,$\ldots$, & $r \cdot, 7 r 4$ & 82.57 & $\cdot, 79 \leq$ & $r, \varepsilon \vee V$ & $11, \varepsilon$ & 1. & r৭,० & Y & 09,1 & or & v & \\
\hline 10 & $\cdot, \ldots 9$ & $9, \Gamma \div \leq$ & 58.33 & $\cdot, v \leq 4$ & $1, \times 0$. & $\leq r, r$ & rA & $r \wedge, \uparrow$ & $\mu \varepsilon$ & $1 \Lambda, r$ & 14 & $\wedge$ & \\
\hline 11 &., .17 & $\Lambda, r V \Psi$ & 65.90 & •, VYY & $1, q \vee \vee$ & $r v, r$ & $Y \varepsilon$ & $\varepsilon v, V$ & $\leqslant r$ & ro & YY & 9 & 'है' \\
\hline 9 & $\cdot,, \leq \leqslant$ & 8,109 & 73.83 & $\cdot, \vee \vee q \leq$ & $r, r i o$ & YY,V & r. & rr & rq & 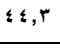 & ra & 1. & $\underline{E}$ \\
\hline ir &,,$\ldots 1$ & $r q, \& \vee v$ & 64.00 & - & $1,94$. & $r r, q$ & r) & $7, r$ & or & 10,9 & $1 \varepsilon$ & " & $\underline{\underline{E}}$ \\
\hline $1 \varepsilon$ &., .1 . & $9, \times 90$ & 63.63 & $\cdot, V Y)$ & $1,9.9$ & $r \cdot, v$ & $r V$ & $\varepsilon v, v$ & $\leqslant r$ & $r 1,4$ & 19 & ir & $\underline{E}$ \\
\hline - & $\cdot, \varepsilon Y Y$ & $1, V Y V$ & 64.37 & $\cdot, \vee \wedge \varepsilon$ & 1,941 & $r \varepsilon, 1$ & $r$. & $r \wedge, \uparrow$ & ع & $r v, r$ & $Y \varepsilon$ & ir & \\
\hline$\varepsilon$ & $\cdot, \ldots 1$ & $r \cdot, \wedge 1 \wedge$ & 75.73 &., 704 & $r, r v r$ & $11, \varepsilon$ & 1. & $\varepsilon$. & \& & $\uparrow \wedge, \uparrow$ & ז & $1:$ & \\
\hline v &,$\ldots$, & $1 v, . \uparrow 1$ & 74.60 & $\cdot, 7 \vee \vee$ & $r, r r \Lambda$ & 14,4 & ir & $\leqslant \wedge, 9$ & $\leq r$ & $r v, 0$ & r & 10 & \\
\hline - & $\cdot, 1 . \varepsilon$ & $\varepsilon, 0 Y T$ & 71.57 & $\cdot, \times 44$ & $r, 1 \leq v$ & YY,V & $r$. & $r q, \wedge$ & ro & $r v, 0$ & r & 14 & \\
\hline$r$ &,,$\ldots 1$ & $r+, 109$ & 78.00 & $\cdot, 0 \wedge \varepsilon$ & $r, r \leqslant$. & $0, v$ & • & $0 \leqslant, 0$ & 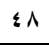 & $r a, \wedge$ & ro & iv & \\
\hline 。 & $\cdot, \ldots r$ & Rr,,$r r$ & 75.37 & $\cdot, \vee \vee १$ & r,YYI & 10,9 & $1 \varepsilon$ & $\varepsilon r$ & $r v$ & $\leqslant r$ & rV & is & \\
\hline - & $\cdot, \mathrm{V} \cdot \mathrm{r}$ & $\cdot, \mathrm{v}, \mathrm{o}$ & 64.37 & $\cdot, \wedge Y V$ & 1,941 & $r v, 0$ & זr & $r, 1$ & rA & $r \cdot, v$ & TV & 19 & \\
\hline ir & $\cdot, \ldots 1$ & $1 \Lambda, \leqslant r Y$ & 64.37 & ,, $7 \vee \leqslant$ & 1,941 & $r q, 1$ & rT & $0 \leqslant, 0$ & $\leq \wedge$ & $19, r$ & iv & $r$ & \\
\hline
\end{tabular}

من نتائج الجدول السابق يتضـح وجود فروق البعد الثالث : المقررات الدراسية في استبانه

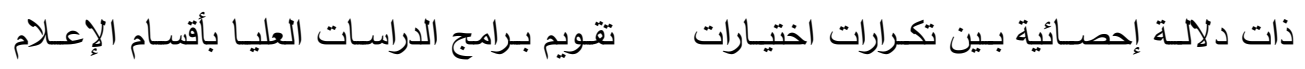
أفراد العينة لبدائل الاستجابات (موافق، موافق التربوي لصالح الاختيار (موافق) في العبارات إلي حد ما، غير موافق) في تقييمهم لعبارات الستة الآتية : 
1. يتتاسب نظام الدراسة (نظام التيرم، السنة) مع المهارات المستهدفة من المقررات. V ا يوجد تحديث للمقررات الدراسية من خلال الأساتذة بالقسم.

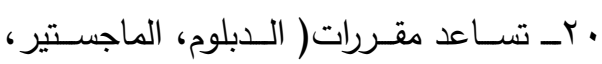
الدكتوراه) علي التطور المهني للباحثين.

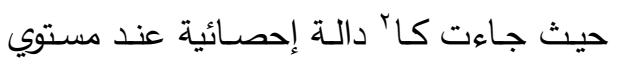

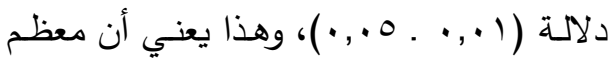

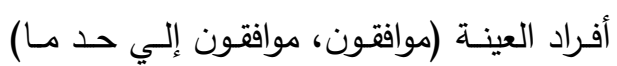
علي أن هذه نقاط قوة في المقررات الدراسية.

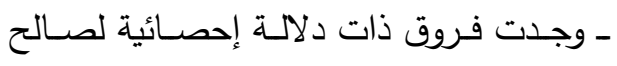
الاختيار (غير موافق) في عبارة واحدة: ^ـ يوجد توازن في عدد المقررات التخصصية والتربوية. وهذا يعني أن معظم أفراد العينة متفقون علي أن المقررات الدراسية تعتمد في تدريسها علي لئي

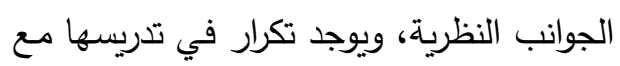

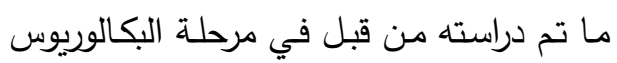

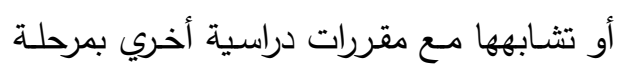

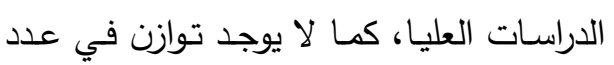

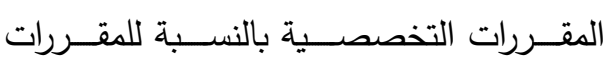

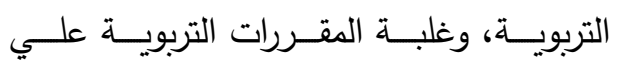
المقـررات التخصصـية فـي برنـامج الإعـلام التربوي، وهذه من نقاط الضـف التي تحتاج

$$
\text { إلي تحسين. }
$$

ـ لا توجـد فـروق ذات دلالـــة إحصــائية بـين

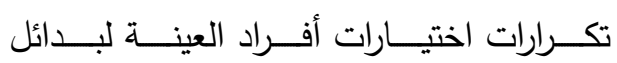

اــــــق المقـررات رسـالة برنـامج الإعــلام التزبوي والكلية.

ع- يوجـد توصـيف لمقـررات برنـامج الإعـلام التربوي.

ه ـ يتفق محتوى المقررات مع التطور العلمي في التخصص.

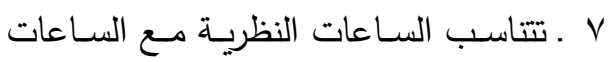
التطبيقية للمقررات. • اـ تتوافر المواد التعليميـة لتدريس المقررات (المراجع ، المعامل، الوسائل التعليمية). 1 اـ يتم تطوير المقرر في ضوه ، نتائج تقويم الباحثين. ـ وجدت فروق دالة إحصائية لصالح الاختيار (موافق إلي حد ما) في العبارات التسعة الآتية:

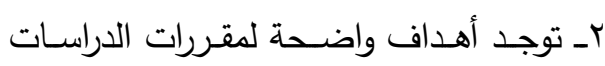
العليا. 7 ـ ـ يغلب الجانب النظري على الجانب العملي في تدريس المقررات بالدراسات العليا.

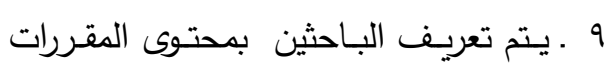
الدراسية والهدف منها. 11. تتناسب المقررات مع احتياجات الباحثين والمجتمع وسوق العمل.

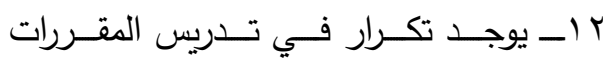

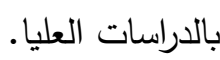
ع اـ تتناسب المهارات المحددة بالمقررات مـع محتواها. 
الترتيب الرابع، العبارة (^ ا) يتم تطوير المقرر في ضوء نتائج تقويم الباحثين في الترتيب الخامس، والعبارتين (1، 0) تحقق المقررات رسالة البرنامج والكلية، يتقق محتوى المقررات مع التطور العلمي في التخصص في الترتيب الساد، العبارة (10) يتتاسب نظام الدراسة (نظام التيرم ،السنة) مع المهارات المستهدفة من المقررات في الترتيب السابع، والعبارة (ع) يوجد توصيف لمقررات برنامج الإعلام التربوي في الترتيب الثامن، والعبارة (• (1) تتوافر المواد التعليمية (المراجع، المعامل، الأدوات، الوسائط

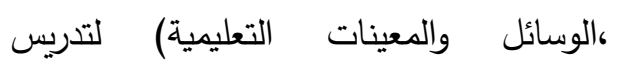
المقررات في الترتيب التاسع، والعبارة (ج) يغلب الجانب النظري على الجانب العملي في الترتيب العاشر، والعبارة (9) يتم تعريف الباحثين بحتوى المقررات الدراسية والهدف منها في الترتيب الحادي عشر ، والعبارة (•r) تساعد مقررات ( الدبلوم، الماجستير، الدكتوراه) علي التطور المهني للباحثين في الترتيب الثاني عشر، والعبارة (1') تيتاسب المقررات

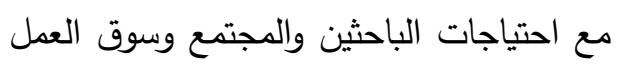
في الترتيب الثالث عشر ، والعبارة (Y I إ) يوجد تكرار في تدريس المقررات بالدراسات العليا في الترتيب الرابع عشر ، والعبارة (^) يوجد توازن

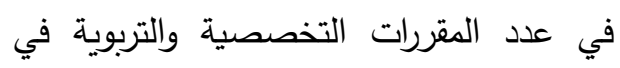

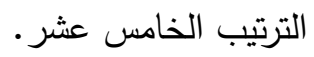

الاستجابات (موافق، موافق إلي حد ما، غير موافق) في العبارات الأربعة الآتية: r. تتلاءم أهداف المقررات مع أهداف البرنامج.

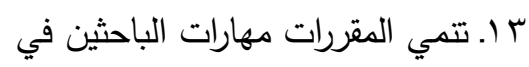

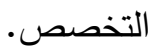
7 ا ـ تتناسب المقررات مع قدرات الباحثين واهتماماتهم. 9 (. تساعد المقررات في حل مشكلات المجتمع وقضاياه. حيث تقاربـت تكـرارات اختيـارات أفـراد العينـة لبـدائل الاسـتجابات، وتقاربـت النسـب المئويــة والمتوسطات الحسابية، وجاءت كا؟ غير دالة

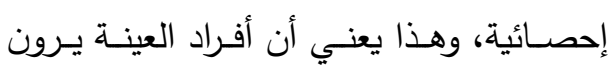

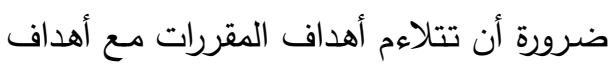

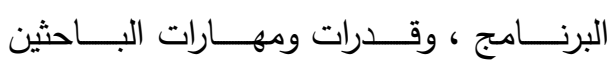

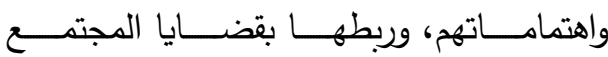

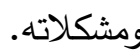
ـ واعتمادا علي المتوسطات الحسابية للعبارات

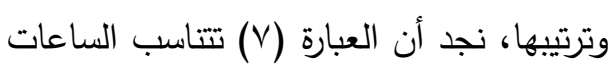
النظرية مع الساعات التطبيقية للمقررات جاءت في الترتيب الأول، العبارة (Y) توجد أهداف واضحة لمقررات الدراسات العليا في الترتيب الثاني، العبارة (IV) يوجد تحديث للمقررات الدراسية من خلال الأساتذة بالقسم

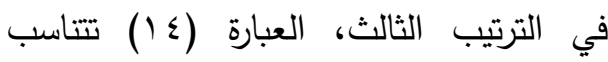
المهارات المحددة بالمقررات مع محتواها في البعد الر ابع: استر اتيجيات التعليم و التعلم. 
جدول (1 ؛ ) التكرارات والمتوسطات الحسابية والانحرافات المعيارية ومربع كا؟ للفروق بين بدائل

الاستجابات ودلالتها الإحصائية للبعد الرابع استراتيجيات التعليم والتعلم،درجة الحربة والاتية

\begin{tabular}{|c|c|c|c|c|c|c|c|c|c|c|c|c|c|}
\hline \multirow{3}{*}{ 荃 } & \multirow{3}{*}{ 点 } & \multirow{3}{*}{ 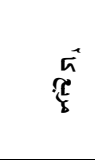 } & \multirow{3}{*}{$\begin{array}{c}\text { اللنسبية } \\
\text { اللهتوسط } \\
\text { المية }\end{array}$} & \multirow{3}{*}{ المعياري } & \multirow[t]{3}{*}{ المتوسط } & \multicolumn{6}{|c|}{ بائل الاختيارات } & \multirow[t]{3}{*}{ p } & \multirow{3}{*}{$\underline{E}$} \\
\hline & & & & & & \multicolumn{2}{|c|}{ غير موافق } & \multicolumn{2}{|c|}{ إلي حـ ما } & \multicolumn{2}{|c|}{ موافق } & & \\
\hline & & & & & & $\%$ & s & $\%$ & ك & $\%$ & s & & \\
\hline 1 & $\therefore, \ldots 1$ & $1 \&, \varepsilon \vee V$ & 74.60 & ., $79 \leqslant$ & r,YrA & $1 \leqslant, \wedge$ & ir & $\leq 4,4$ & \&1 & $r \wedge, \uparrow$ & $r \varepsilon$ & 1 & \\
\hline r & .,.rT & $8,9,9$ & 69.67 & $\cdot, \mathrm{V} \mu \mathrm{V}$ & $r, . q$. & $r Y, Y$ & r. & $\{0,0$ & $\{$. & $r, \Lambda$ & rA & $r$ & \\
\hline 1 & $\cdot, \ldots r$ & $11,71 \leqslant$ & 64.37 & $\cdot, \mathrm{v} \cdot \mathrm{v}$ & 1,941 & $Y \Lambda, \xi$ & ro & 0. & $\leqslant \leqslant$ & $r 1,4$ & 19 & $r$ & \\
\hline- & $\cdot, 0 \vee \mu$ & $1,11 \leqslant$ & 63.63 & $\cdot, \wedge 11$ & $1,9.9$ & $r v, 0$ & $r \mu$ & $r \leqslant, 1$ & r. & $Y \Lambda, \xi$ & ro & $\varepsilon$ & \\
\hline- & $\cdot, 1 \cdot 1$ & $\{,\{00$ & 64.37 & - $\mathrm{v}$ ० & 1,941 & $r, \Lambda$ & rA & $\varepsilon r, r$ & rᄉ & ro & rr & - & \\
\hline v & $\cdot, \ldots 1$ & $11,9.9$ & 63.63 & ., IVI & $1,9.9$ & $r v, r$ & $r \&$ & $0 \leqslant, 0$ & $\leqslant \wedge$ & $i \Lambda, r$ & 17 & 9 & $\underline{6}$ \\
\hline - & $\cdot, \ldots \varepsilon$ & $11, .41$ & 65.90 & $\cdot, v_{1}$. & $1,9 \vee v$ & $r, 1$ & rT & $\circ$. & « & $r \mu, q$ & $r$ & v & E \\
\hline$\varepsilon$ &,$\ldots \wedge$ & 9,041 & 66.27 & $\cdot, \times 19$ & $1,9 \wedge 1$ & $r, 1$ & r & $\varepsilon \wedge, q$ & $\varepsilon r$ & ro & rr & $\wedge$ & : \\
\hline 1 &.,$\ldots r$ & $11,71 \leq$ & 64.37 & $\cdot, \mathrm{v} \cdot \mathrm{V}$ & $1,9+1$ & $r \Lambda, \varepsilon$ & ro & $\circ$. & $\varepsilon \leqslant$ & $r 1,4$ & 19 & 9 & $\frac{E_{1}}{\xi_{i}}$ \\
\hline- & r, r०4 & $r, .71$ & 67.03 & 促, & $r, .11$ & $\mu_{4, \varepsilon}$ & rr & $r 4,1$ & r & $r v, 0$ & re & 1. & \\
\hline$\wedge$ & $\cdot, \ldots 9$ & $9, r 4 \leqslant$ & 58.33 & $\cdot, v \leqslant 4$ & $1, v_{0}$. & $\varepsilon r, r$ & $r \wedge$ & $\mu \wedge, \uparrow$ & $r \varepsilon$ & $1 \Lambda, r$ & 17 & 11 & \\
\hline 9 &,$\ldots 1$ & $r 9, .71$ & 52.27 & $\cdot, \mathrm{vv}$. & 1,041 & $r, r$ & or & YY,V & $r$. & iv & 10 & ir & \\
\hline 1. & 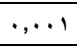 & $r \Psi, r, 0$ & 51.87 & $\cdot, v \cdot A$ & 1,004 & $\triangle 4, \wedge$ & $\therefore$ & $r \cdot, v$ & iv & ${ }_{1} \mathrm{r}, \mathrm{O}$ & 11 & ir & \\
\hline$r$ & $\cdot, \ldots 1$ & $10,9 \vee V$ & 67.03 & צוגז, & $r, .11$ & $r Y, V$ & r. & or, \& & $\leqslant v$ & $r+q$ & r & $1 \varepsilon$ & \\
\hline
\end{tabular}

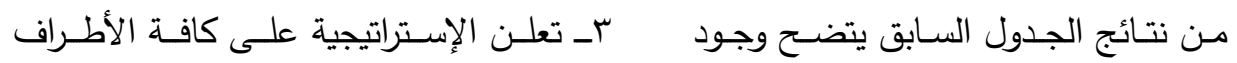

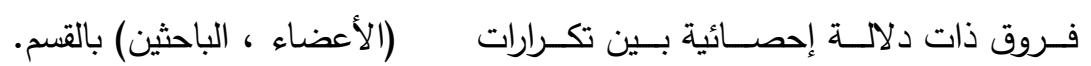

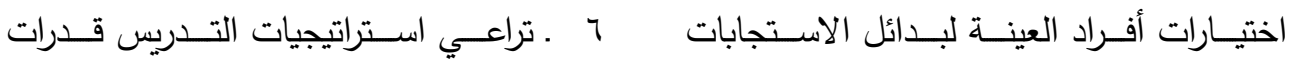
(موافق، موافق إلي حد مـا، غير موافق) في الباحثين وخصائصهم.

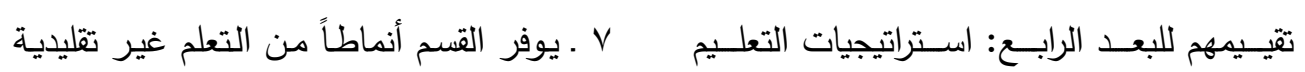
والتعلم: في استبانه تقويم برامج الدراسات العليا (التعلم الذاتي، الالكتروني).

بأقسـام الإعـلام التربـوي، لصــالح الاختيـار ـ ـ تستخدم التقنيات الحديثة في التدريس.

(موافق إلـي حـد مـا) في العبـارات الثمانيـة 9 ـ يعتمد التدريس علي المحاضرات فقط.

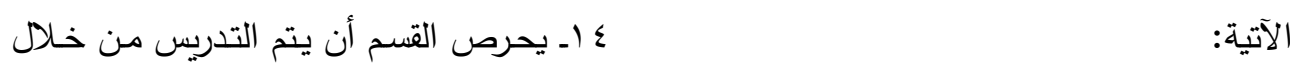

ا. يضع القسم إستراتيجية للتعليم والتعلم تحقق متخصصين.

حيث جاءت كا؟ دالة إحصـائية عند مستوي رسالته وأهدافه.

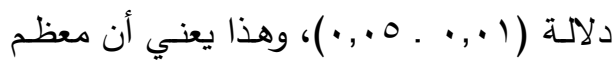

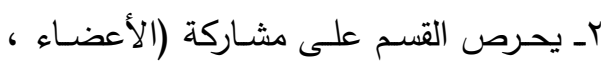

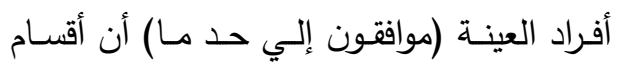

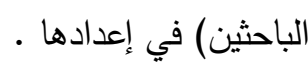
الإعلام التربوي تضع استراتيجيه للتعليم والتعلم 
للعبارة (9) يعتمدـ التدريس علي المحاضـرات النظريـة ، تعد من نقاط الضـعف في برنـامج الإعلام التربوي. - لا توجــ فـروق ذات دلالـــة إحصــائية بـين

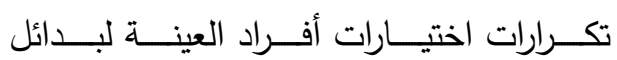

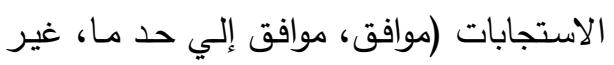
موافق) في العبارات الثلاثة الآتية :

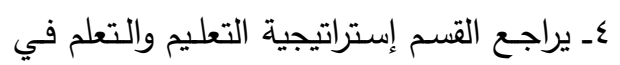
ضوء نتائج (الامتحانـات، استقصـاء الباحثين وأعضاء هيئة التدريس ومعاونيهج). ه. يستقيد القسم من نتائج مراجعة استراتيجيات

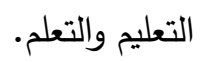
• اــ يـوفر القسـم إمكانيـات للتدريب (مسـرح، استديو،قاعة صحفية). حيـث تقاربـت تكـرارات اختيـارات أفـراد العينــة لبـدائل الاسـتجابات، وتقاربـت النسـب المئويــة والمتوسطات الحسابية، وجاءت كا؟ غير دالة إحصائية.

لذا ينبغي وجود إستراتيجية للتعليم والتعلم ومراجعتها دوريا في ضوء نتائج (الامتحانات،

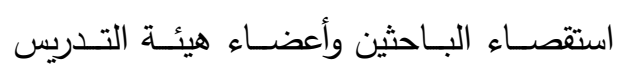
ومعاونيهم)،مع الاستفادة من هذه المراجعة، مع ولئح

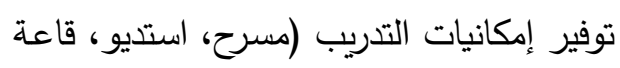
صحفية) والتدريب العملي لهم في المؤسسات

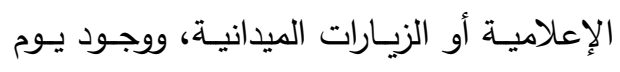

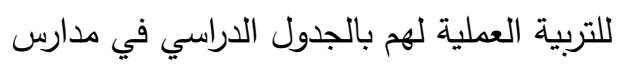

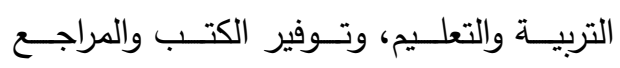

ويثـارك فيهـا الأطـراف المعنيـة وأنهـا معلنـة وتراعـي قـدرات البـاحثين وخصائصـهم، كمــا تسـتخدم التقنيـات الحديثـة في التـدريس وأن القسم يستخدم أنماطا غير تقليدية في التعلم، لهن من خـلال أعضـاء هيئة تدريس متخصصين، وهذا يعني أن هذه نقاط قوة في برنامج الإعلام التربوي، على الرغم من أن الباحث عند تحليله

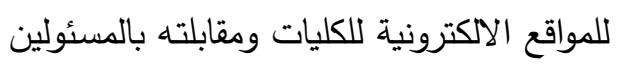

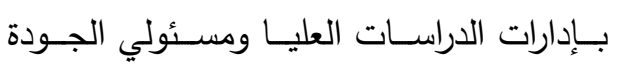
بالكليات لم يجد أي استراتيجيات للتعلم والتعلم

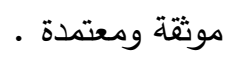
- وجدت فروق ذات دلالــة إحصـائية لصـالح

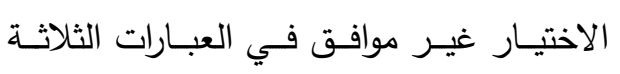
الآتية: الآتل ا إـ يوجد تدريب ميداني يثـارك فيـه طـلاب

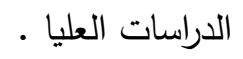
r ا ـ يـوفر القســم رحـلات تعليميــة وزيــارات ميدانية لمؤسسات التدريب. ب ا ــــوفر القسـم المراجـع والمجـلات العلميـة الحديثة بالمكتبة.

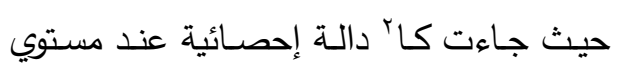
دلالــة ( ( ., ))، وهـــا يعنـي أن معظـم أفـراد

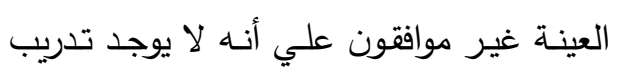
ميداني يشارك فيه الطلاب، أو رحلات تعليمية

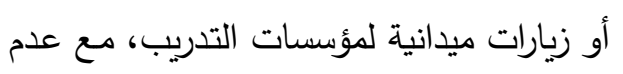

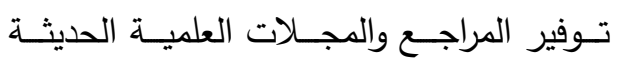
بالمكتبة وهذه النقاط الثلاثة السابقة بالإضـافة 
الالكتروني) في الترتيب الخامس، والعبارة (r) ، 9 (9 تعلن الإستراتيجية على كافة الأطراف

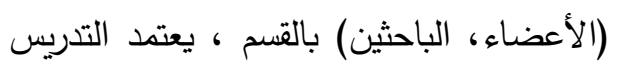

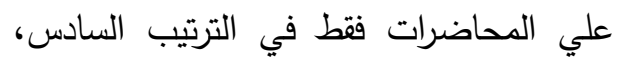
العبارة(†) تراعي استراتيجيات التدريس قدرات

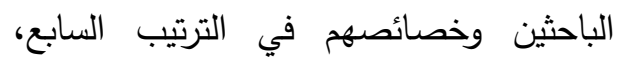
والعبارة (1) يوجد تدريب ميداني يشارك فيه

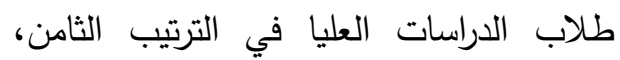
والعبارة (Y) (I) يوفر القسم رحلات تعليمية وزيارات ميدانية لمؤسسات التدريب في الترتيب التاسع، والعبارة (r) (1) يوفر القسم المراجع والمجلات العلمية الحديثة بالمكتبة في الترتيب • العاشر
والاسـتفادة مـن المكتبـة الرقميـة والاسـتعارة ، ووجود مكتبة خاصة بالدراسات العليا. ـ واعتمادا علي المتوسطات الحسابية للعبارات وترتيبها نجد أن العبارة (1) يضع القسم إستراتيجية للتعليم والتعلم تحقق رسالته وأهدافه

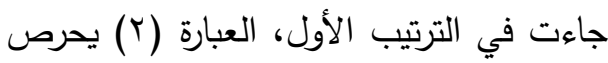
القسم على مشاركة (الأعضاء، الباحثين) في

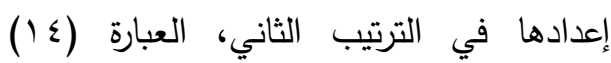
يحرص القسم أن يتم التدريس من خلال متخصصين في الترتيب الثالث، العبارة (^) لتخدئ تستخدم التقنيات الحديثة في التدريس في لي الترتيب الرابع، العبارة (V) يوفر القسم أنماطاً

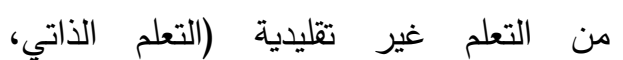
البعد الخامس: أساليب التقويم.

جدول (9 ؛ ) التكرارات والمتوسطات الحسابية والانحرافات المعيارية ومربع كا`` للفروق بين بدائل

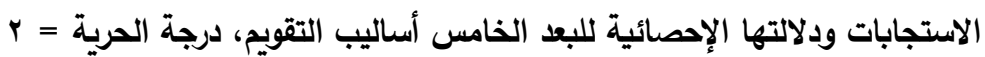

\begin{tabular}{|c|c|c|c|c|c|c|c|c|c|c|c|c|c|}
\hline \multirow{3}{*}{ 䒫 } & \multirow{3}{*}{ 㫡 } & \multirow{3}{*}{$\overrightarrow{\frac{5}{2}}$} & \multirow{3}{*}{ للمتوسط النسبية } & \multirow{3}{*}{ المعياري } & \multirow[t]{3}{*}{ المتوسط } & \multicolumn{6}{|c|}{ بدائل الاختيارات } & \multirow[t]{3}{*}{ b } & \multirow{3}{*}{$\underline{E}$} \\
\hline & & & & & & \multicolumn{2}{|c|}{ غير موافق } & \multicolumn{2}{|c|}{ إلي حد ما } & \multicolumn{2}{|c|}{ موافق } & & \\
\hline & & & & & & $\%$ & s & $\%$ & ك & $\%$ & ك & & \\
\hline 1 &,$\ldots 1$ & $0 r, 0 \leqslant 0$ & 87.87 & -, ora & צוזו, & $r, r$ & r & $\Gamma, \Lambda$ & rA & 90,9 & 01 & 1 & \\
\hline- & ., \&YY & $1, v Y v$ & 68.93 & $\cdot, \vee \vee \wedge \varepsilon$ & $r, \cdot{ }^{\prime} \wedge$ & $r v, r$ & $Y \varepsilon$ & $\Gamma \wedge, \uparrow$ & $\Gamma \varepsilon$ & $r \leqslant, 1$ & $r$. & r & \\
\hline 。 & $0,+r 1$ & ४, $9 \mathrm{VV}$ & 66.27 & .,$V \Psi \varepsilon$ & $1,9 \wedge \wedge$ & $r v, r$ & $r \varepsilon$ & $\leq 4,7$ & \&1 & r४, & $r \mu$ & $r$ & \\
\hline- &., $0 \ldots$ & $1, r \wedge 4$ & 70.07 & .,AIV & $r, 1 . r$ & $r_{\Lambda, \&}$ & ro & r & rq & $r \wedge, \uparrow$ & $r \varepsilon$ & $\varepsilon$ & \\
\hline v &,,$\ldots 1$ & $r \leqslant, r 90$ & 52.63 & , VथN & $1,0 \vee 9$ & $\triangle 4, \wedge$ & o. & $Y \Lambda, \varepsilon$ & ro & $1 \leqslant, \wedge$ & 14 & 0 & \\
\hline 1 &,,$\ldots 1$ & $1\{, .71$ & 58.33 &., 791 & 1,vo. & $\Gamma 9, \wedge$ & ro & $\{0,0$ & \&. & $1 \varepsilon, A$ & ir & 1 & 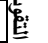 \\
\hline- & .,.4r & $0,0 \leqslant 0$ & 59.83 & ., va. & 1,va० & $\varepsilon r, r$ & $r \wedge$ & $r \leqslant, 1$ & r. & $r Y, Y$ & $r$. & $\mathrm{v}$ & E. \\
\hline- & .,9Yะ &., 109 & 66.27 & $\cdot, \wedge \cdot 9$ & $1,9 \wedge 1$ & rr & rq & $r 0, r$ & $\mu$ & $\Gamma, \Lambda$ & rA & $\wedge$ & \\
\hline 1 &,$\ldots$, & $0 \%, r .0$ & 87.87 & $\cdot, 09$. & rצוTו & $0, v$ & $\bullet$ & ro & rY & $79, r$ & 7 & 9 & \\
\hline$r$ &,,$\ldots 1$ & $r r, 0 \leqslant 0$ & 79.53 &., 10. & r, rAT & 9,1 & $\wedge$ & $\varepsilon r, r$ & rA & $\leqslant v, v$ & $\leqslant r$ & 1. & \\
\hline$\varepsilon$ & ., & $\curlyvee, \wedge \leqslant 1$ & 72.33 & $\cdot, v \leqslant 4$ & r,iv. & $r \cdot, 0$ & 11 & $\leq r$ & rv & $r v, 0$ & $r \mu$ & 11 & \\
\hline$r$ &,$\ldots$, & $10, v, 0$ & 78.00 & , VYo & $r, r \leqslant$. & $1 \varepsilon, \wedge$ & $1 \%$ & $\Gamma_{4}, \varepsilon$ & rr & $\leqslant \wedge, q$ & \& & Ir & \\
\hline
\end{tabular}

مـن نتـائج الجدول السـابق يتضـح وجـود اختيــارات أفـراد العينــة لبــائل الاســتجابات

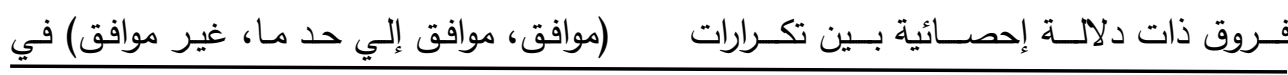


تقيـيمهم للبعـد الخـامس: أسـاليب التقويم في تطوير المقررات، كما يحرص علي قياس رضا اسـتبانه تقـويم بـرامج الدراسـات العليـا بأقسـام الباحثين.

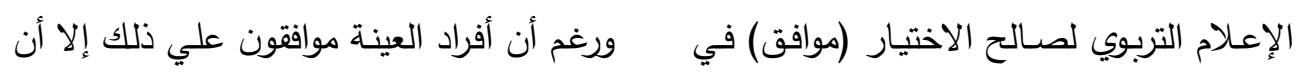

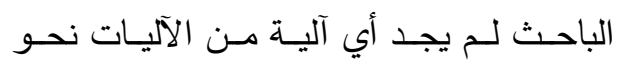

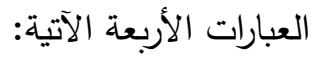

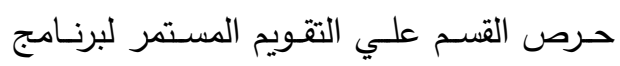

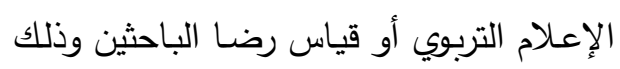
بخـلاف الاختبـارات وتقـارير الإشـراف لرسـائل

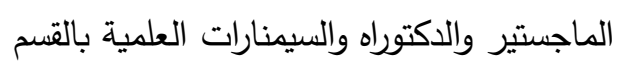
وإعلان النتائج للطلاب. - في حين وجدت فروق ذات دلالة إحصائية لصالح الاختيار (غير موافق) في عبارة واحدة هي: ه. يتم تحليل نتائج تقويم الباحثين. حيث جاءت كا؟ دالة إحصائية عند (1 ( , •)

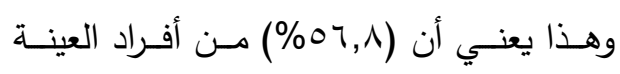

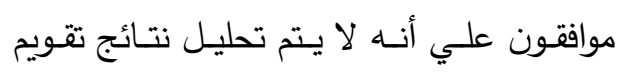
الباحثين ومـن ثم عدم الإفـادة مـن نتائج هذا

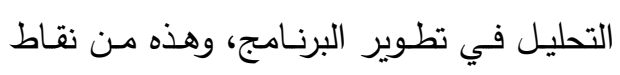
الضعف التي في حاجة للتحسين.

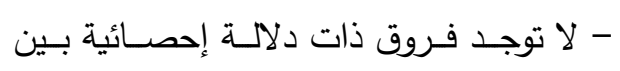

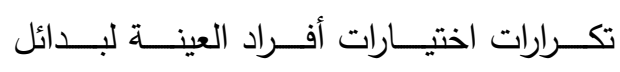

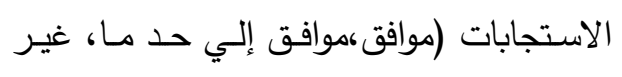
موافق) في العبارات الأربعة الآتية: r- يـوفر القسم آلية للتأكد مـن عدالـة تقويم الباحثين.

ع. يستخدم القسم نظام المتحنين الخارجيين. 
Vـ يناقش القسم تقارير نتائج الامتحانـات من القسم علي التقويم المستمر لبرنـامج الإعـلام

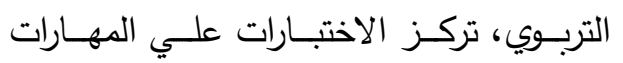

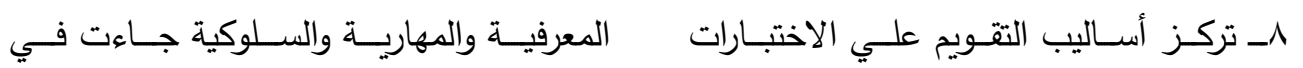
الترتيب الأول، والعبارة (· • (1) اختبارات القبول ولبه ذات معايير محددة في الترتيب الثاني، والعبارة (r ( ) يحرص القسم على قياس رضا الباحثين

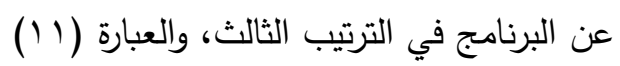

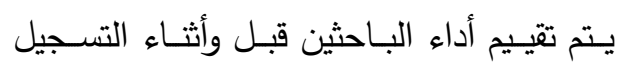
للدرجات العلميـة في الترتيب الرابع، والعبارة

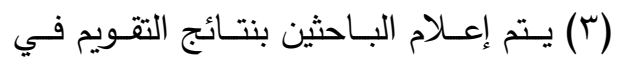

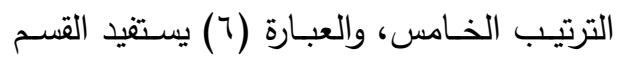
من تحليل نتائج الباحثين في تطوير البرنامج ومقرراته في الترتيب السادس، العبارة (0) يتم تحليل نتائج تقويم الباحثين في الترتيب السابع.

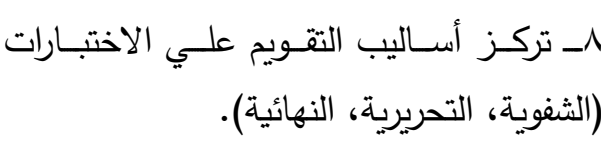

$$
\begin{aligned}
& \text { هذا يعني أن جميع أفراد العينة ليس بينهم }
\end{aligned}
$$

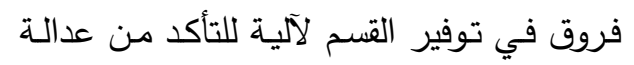
تقــويم البـاحثين، واســتخدام نظــام الممتحنـين الخارجيين، ومناقثـة تقارير نتائج الامتحانسات مـن خـلال مجلسـه، واعتمـاد أسـاليب التقـويم علي الاختبارات( الثفوية، التحريرية، النهائية). حيث تقاربت تكرارات اختيـارات أفـراد العينـة لبـدائل الاسـتجابات وتقاربــت النسـب المئويـة والمتوسطات الحسابية، وجاءت كا؟ غير دالة إحصائية. - واعتمادا علي المتوسطات الحسابية للعبارات

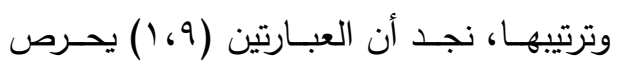
البعد السادس: أعضاء هيئة التدريس.

\begin{tabular}{|c|c|c|c|c|c|c|c|c|c|c|c|c|c|}
\hline \multirow{3}{*}{$\begin{array}{l}\text { 甚 } \\
\underline{\underline{E}} \\
\underline{E}\end{array}$} & \multirow{3}{*}{$\begin{array}{l}\text { 宽 } \\
\underline{\underline{E}}\end{array}$} & \multirow{3}{*}{$\stackrel{\vec{\hbar}}{\mathfrak{r}}$} & \multirow{3}{*}{ 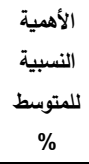 } & \multirow{3}{*}{ الانحرا } & \multirow{3}{*}{ ط ط } & \multicolumn{6}{|c|}{ بائل الاختيارات } & \multirow[t]{3}{*}{ P } & \multirow{3}{*}{$\underline{E}$} \\
\hline & & & & & & \multicolumn{2}{|c|}{ غير موافق } & \multicolumn{2}{|c|}{ إلي حد ما } & \multicolumn{2}{|c|}{ موافق } & & \\
\hline & & & & & & $\%$ & S & $\%$ & S & $\%$ & ك & & \\
\hline- & r, $1 \leqslant v$ & $r, \wedge \leqslant 1$ & 64.00 & •, VII & $1,94$. & rr & rq & $\varepsilon r$ & $r v$ & ro & rr & 1 & - \\
\hline
\end{tabular}
جدول ( • ) التكرارات والمتوسطات الحسابية والانحرافات المعيارية ومربع كاب للفروق بين بدائل

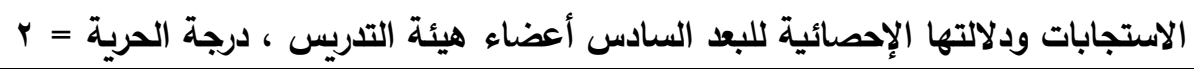




\begin{tabular}{|c|c|c|c|c|c|c|c|c|c|c|c|c|}
\hline 。 & .,.. & $r 1,709$ & 82.17 & ,, 40 & $r, 440$ & $0, v$ & 。 & $\leq r$ & rv & Or,r & $\leq 4$ & $r$ \\
\hline$\varepsilon$ &,$\ldots$, & $r \cdot, \leqslant \psi r T$ & 82.57 & r & $r, \xi \vee V$ & $\wedge$ & v & ץ & rr & $\Delta 0, v$ & $\leqslant 9$ & $r$ \\
\hline v & , ,..r & $\mid r, 071$ & 72.70 & $\cdot, v, r$ & $r, 1{ }_{1}$ & IV & 10 & $\varepsilon V, V$ & $\leq r$ & $r \Delta, r$ & ri & $\varepsilon$ \\
\hline 1 & ,... & lV,r.o & 76.87 & 证, & $r, r .4$ & $1 Y, 0$ & 11 & $\varepsilon \varepsilon, r$ & ra & $\varepsilon r, r$ & rs & 。 \\
\hline - & , ,.00 & $0, \wedge 1 \wedge$ & 66.67 & r, $v \leqslant r$ & $r, \ldots$ & $r v, r$ & $r \varepsilon$ & $\leqslant 0,0$ & $\varepsilon$. & $r v, r$ & $r \leqslant$ & 1 \\
\hline$r$ &,$\ldots$, & 00,409 & 88.23 & , , & $r, Y \leqslant v$ & $r, r$ & r & $r \cdot, v$ & $r V$ & IV & ०Q & $v$ \\
\hline$r$ &,$\ldots$, & rV, IAr & 84.07 & , ,014 & r,orr & $\varepsilon, 0$ & $\varepsilon$ & $r \Lambda, \tau$ & & א & 0 . & $\wedge$ \\
\hline$\wedge$ & .,.. & $|v, \wedge| \wedge$ & 66.67 & A ז', & $r, \ldots$ & $r r, V$ & $r$. & $0 \leqslant, 0$ & $\leqslant \wedge$ & $r Y, V$ & $r$. & 9 \\
\hline 1 & ,... & 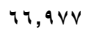 & 89.77 & -, orr & r, Tar & ץ, ६ & $r$ & rr,q & YI & $V r, V$ & צ & 1. \\
\hline r & .,.. & 00,409 & 88.23 & , OYY & $r, Y \leqslant v$ & $r, r$ & $r$ & $r \cdot, V$ & YV & IV & $\Delta q$ & "1 \\
\hline
\end{tabular}

- وجـدت فـروق دالــة إحصـــائية لصــالح

الاختيـار (موافت إلي حد مـا) في العبـارات

الثلاثة الآتية: - التية

ع. يشارك في أنشطة ضمان الجودة والتطوير

بالقسم.

ه. يساهم في تتمية موارد الكلية.

9

والباحثين.

حيث جـاءت كا' دالة إحصـائية عند مستوي دلالـة (1 ., • ) ، وهـذا يعنـي أن معظم أفـراد العينـة (موافقـون، موافقـون إلـي حـد مــا) أن

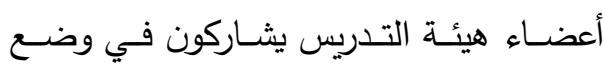
الخطة البحثية للقسم، وأنشطة المجتمع وتتمية البيئة، وتوافق مـا يقوم بتدريسـه مـع مـا هـو موجود بالمقرر، ويستخدمون التقنيات الحديثة في التدري، وتوجيه الباحثين للمراجع العلمية

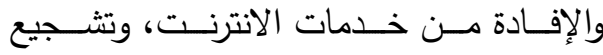
البــاحثين علـي البحــث العلمـي والابتكــار ، وموافقون إلي حد ما أن أعضـاء هيئة التدريس يشـاركون في أنشـة ضــــان الجـودة وتتميـة موارد الكلية، والتواصل مع الزملاء والباحثين،
مـن نتائج الجدول السـابق يتضـح وجـود فـروق ذات دلالــة إحصــائية بــين تكـرارات اختيــارات أفـراد العينــة لبــدائل الاســتجابات (موافق، موافق إلي حد مـا، غير موافق) في تقيـيمهم للبعد السادس:أعضـاء هيئة التدريس في استبانه تقويم برامج الدراسات العليا بأقسام الإعلام التربوي لصالح الاختيار (موافق) في العبارات الستة التالية : r- يشـارك أعضـاء هيئة التدريس في الخطـة البحثية للقتسم بـ يسـاهم في أنشـطة خدمــة المجتمـع وتتميـة البيئة . . يتوافق مـا يقوم بتدريسـه بالمحاضـرات مـع V ما هو موجود بالمقرر • A . يستخدم التقنيات الحديثة في التدري. • 1 ـ يوجـه البـاحثين للمراجـع العلميـة والإفـادة من الانترنت. 11 العلمي والابتكار . 
عضو هيئة التدريس الباحثين للمراجع العلمية

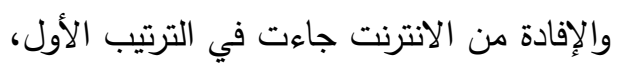

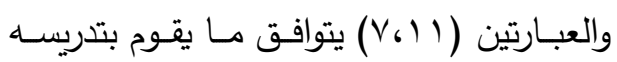

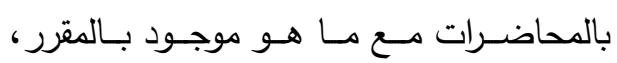

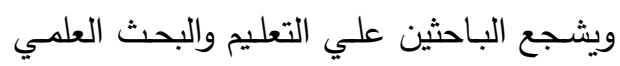

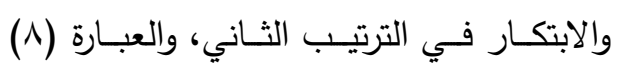
يسـتخدم التقنيـات الحديثـة فـي التـدريس في ولتي الترتيب الثالث، والعبارة (ץ) يساهم في أنشطة خدمة المجتمع وتتمية البيئة في الترتيب الرابع،

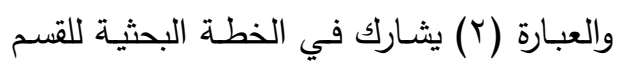

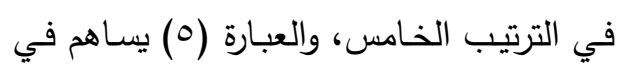
تتمية موارد الكلية في الترتيب السادس، والعبارة (ع) يشارك في أنشطة ضمان الجودة والتطوير

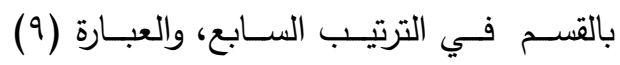
يحرص علي التواصل مـع الزملاء والباحثين

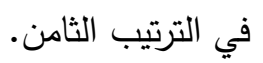

فهم يرون أن هذه من نقاط القوة التي يجب دعمها. - لا توجد فـروق ذات دلالـــة إحصـائية بـين

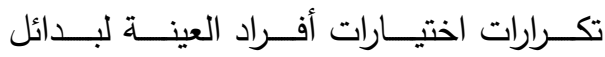

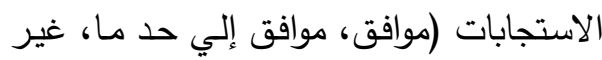

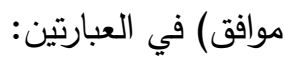
1 ـ يلتزم بالجداول الدراسية ووقت المحاضرة.

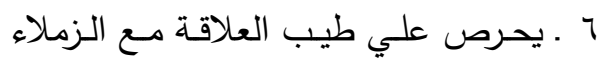
والرؤساء، والباحثين. وهذا يعني أن جميع أفراد العينـة ليس بينهم

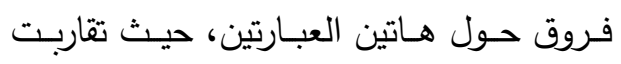

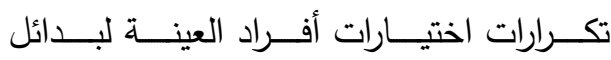
الاستجابات (موافق، موافق إلي حد ما، غير

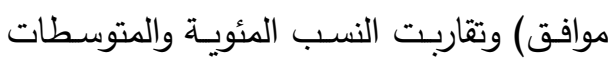
الحسابية، وجاءت كا؟ غير دالة إحصائية. - وبمقارنة المتوسطات الحسابية لعبارات هذا

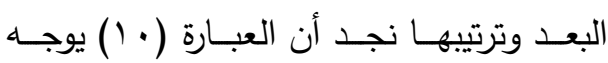

جدول( إن)التكرارات والمتوسطات الحسابية والانحرافات المعيارية ومربع كاء للفروق بين بدائل الاستجابات ودلالتها الإحصائية للبعد السابع البحث العلمي، درجة الحربة العربة

\begin{tabular}{|c|c|c|c|c|c|c|c|c|c|c|c|c|c|}
\hline \multirow{3}{*}{ يب } & \multirow{3}{*}{ الدلالة } & \multirow{3}{*}{ مربع كا' } & \multirow{3}{*}{$\begin{array}{c}\text { اللنهبية } \\
\text { اللمتوسط \% } \\
\end{array}$} & \multirow{3}{*}{ المعياري } & \multirow{3}{*}{ المتوسط } & \multicolumn{6}{|c|}{ بدائل الاختيارات } & \multirow{3}{*}{ P } & \multirow{3}{*}{$\underline{E}$} \\
\hline & & & & & & \multicolumn{2}{|c|}{ غير موافق } & \multicolumn{2}{|c|}{ إلي حـ ما } & \multicolumn{2}{|c|}{ موافق } & & \\
\hline & & & & & & $\%$ & 5 & $\%$ & S & $\%$ & s & & \\
\hline$r$ & $\cdot, \cdots$, & $\leqslant \varphi, q \vee \vee$ & 85.20 & $\cdot, 101$ & Y,004 & 9,1 & $\wedge$ & $r, 1$ & rr & $\leq 4, \wedge$ & ov & 1 & \\
\hline- & $\cdot, 1 \wedge$ & $r, \leqslant \psi r$ & 71.97 & $\cdot, \lambda 1 \leqslant$ & $r, 109$ & $\mathrm{r}, 1$ & $r r$ & $r, 1, \wedge$ & $\lceil\Lambda$ & $\leqslant r$ & $r v$ & $r$ & \\
\hline 10 &.,$\ldots 1$ & $12,11 \leqslant$ & 59.47 & $\cdot, v \cdot r$ & $1, \vee \wedge \varepsilon$ & $r v, 0$ & rr & $\leq 4, \uparrow$ & $\leqslant 1$ & 10,9 & $1 \leqslant$ & $r$ & \\
\hline- & $\cdot, \cdot \wedge 0$ & $\varepsilon, 9 \pi r$ & 65.50 & $\cdot, v \leqslant 9$ & 1,970 & $r 9,0$ & ry & $\varepsilon \leqslant, r$ & ra & $r 4,1$ & rr & $\leqslant$ & ' \\
\hline 11 & $\cdot, \cdot, 4$ & 7,109 & 70.07 & $\cdot, v \leqslant r$ & $r, 1 \cdot r$ & $r Y, Y$ & $r \cdot$ & $\varepsilon \leqslant, r$ & ra & $r r$ & rq & $\circ$ & 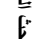 \\
\hline • &,$\ldots 1$ & r4,7r4 & 84.07 &., 14 & r,orr & 9,1 & $\wedge$ & $r 9,0$ & $r 4$ & $71, \varepsilon$ & $0 \leqslant$ & 1 & \\
\hline 15 &,$\ldots$, & $18, r \wedge 4$ & 60.97 & $\cdot, \times \wedge 1$ & 1, Arq & $r$ & ra & 01,1 & $\leq 0$ & 10,9 & $1 \leqslant$ & v & \\
\hline$r$ &,,$\ldots 1$ & ra,7ru & 84.83 & $\cdot, 0 \wedge 0$ & $r, 0 \leqslant 0$ & $\varepsilon, 0$ & $\varepsilon$ & $r 4, \varepsilon$ & rr & 09,1 & Or & $\wedge$ & \\
\hline 1 &,,$\ldots 1$ & $1 \leqslant, r \leqslant 1$ & 77.63 & , vor & r,rra & iv & 10 & $r r$ & ra & $\circ$. & $\leq \varepsilon$ & 9 & \\
\hline
\end{tabular}




\begin{tabular}{|c|c|c|c|c|c|c|c|c|c|c|c|c|}
\hline ir & , , . 1 & $19, \vee 90$ & 67.03 & - 179 & $r, .11$ & $r, 4$ & 19 & $00, v$ & $\leqslant 9$ & $r Y, Y$ & $r$. & 1. \\
\hline 17 & $\cdot, \ldots 1$ & $19, V Y V$ & 54.53 & . & $1,7 \times 4$ & $\varepsilon v, v$ & $\leqslant r$ & $\{\cdot, q$ & ry & $11, \varepsilon$ & 1. & 11 \\
\hline$\wedge$ &,$\ldots 1$ & 14,709 & 75.73 & $\cdot, v, Y$ & Y,YVY & $1 \leqslant, \wedge$ & ir & $\varepsilon r, r$ & $\mu \Lambda$ & $\sum r$ & $r v$ & ir \\
\hline $\mathrm{v}$ & 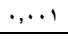 & $|V, r| \leq$ & 76.13 & •, TVV & $r, Y \wedge \leqslant$ & $1 \%, 0$ & 11 & $\leq 4,4$ & \$1 & $\varepsilon$. & $r$ & 15 \\
\hline$\varepsilon$ &,$\ldots 1$ & $r v, q \pi r$ & 84.47 & . & $Y, O Y \leqslant$ & $\wedge$ & $\mathrm{v}$ & $r \cdot, v$ & $r v$ & $11, \varepsilon$ & $0 \leqslant$ & $1 \leqslant$ \\
\hline 1 &,$\ldots$, & $\leqslant \vee, \wedge \wedge \uparrow$ & 86.73 & ., $00 \mathrm{~V}$ & $r, Y, r$ & $r, \xi$ & $r$ & $r r$ & ra & 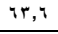 & .4 & 10 \\
\hline 1. & ., & $\checkmark, \wedge \leqslant 1$ & 70.83 & $\cdot, \mathrm{V} \times \mathrm{q}$ & r, Y Yo & $r 1,4$ & 19 & $\leq \leqslant, 1$ & ra & $r \leqslant, 1$ & $r$. & 14 \\
\hline Ir &,,$\ldots 1$ & $10,9 \vee \mathrm{V}$ & 67.03 & 4 צ', & $r, .11$ & $r, \gamma$ & $r$. & ०५, \& & $\leqslant v$ & $r \quad r, q$ & $r$ & iv \\
\hline 9 & $\cdot, \cdots 1$ & $r \Lambda, 71 \leqslant$ & 73.10 & $\cdot, \bullet \wedge \varepsilon$ & $r, 194$ & 9,1 & $\wedge$ & $r \%, 0$ & $\because 0$ & $Y \wedge, \varepsilon$ & ro & 11 \\
\hline $1 \leqslant$ & $\cdot, \ldots 1$ & $\mid \varepsilon, 71 \leqslant$ & 59.83 & 促 & $1, \vee 9_{0}$ & 01,1 & $\leqslant 0$ & $1 \wedge, r$ & 14 & $r \cdot, v$ & rV & 19 \\
\hline
\end{tabular}

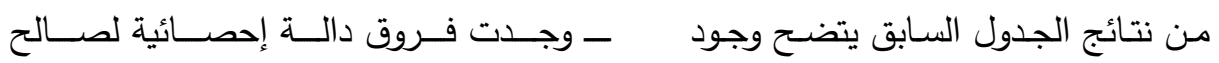

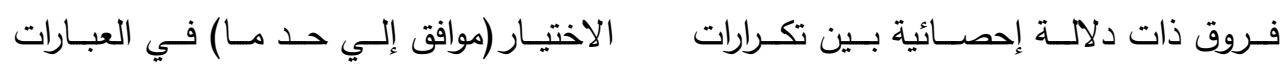

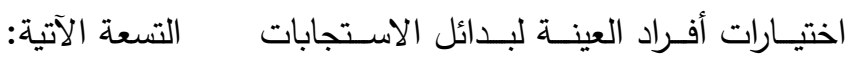

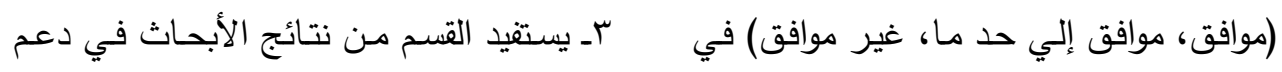

تتييمهم للبعد السابع:البحث العلمي والإشراف وتعزيز العملية التعليمية.

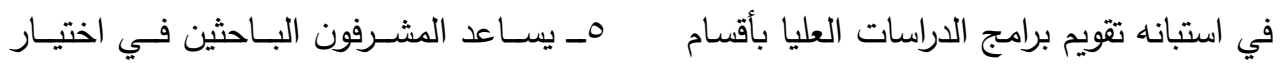

الإعلام التربوي لصالح الاختيار (موافق) في موضوعاتهم البحثية .

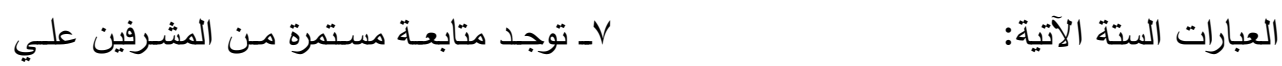

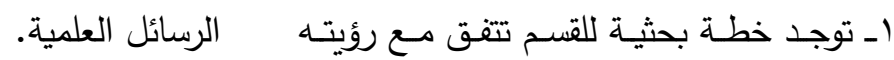

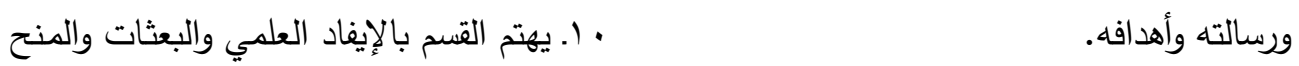

7. ينشغل المشرفون بالمحاضرات علي حساب البحثية للباحثين.

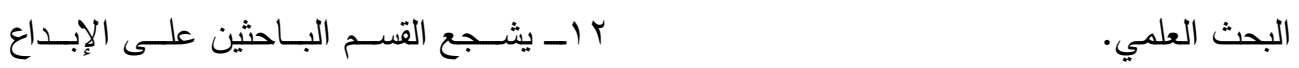

^ــ توجـد قاعـدة بيانـات بالأبحـاث ورسـائل والابتكار في بحوثهم.

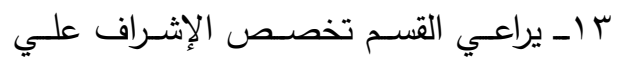

(الماجستير والدكتوراه).

9- يوفر القسم المراجع المتخصصـة والحديثة رسائل الماجستير والدكتوراه.

7 ا ا. يسمح القسم للباحثين باختيار مشرفيهم.

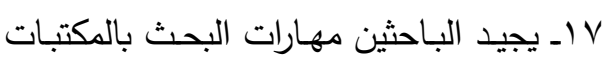

$$
\text { وقواعد البيانات العالمية. }
$$

في التخصص.

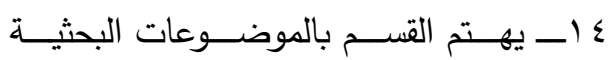

بتخصصات الإعلام التربوي.

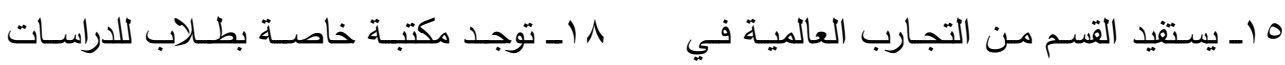

$$
\text { تخصصات الإعلام التربوي. العليا. }
$$

حيث جاءت كا؟ دالة إحصائية عند مستوي

دلالــة ( ( . . )، وهـذا يعنـي أن معظم أفـراد 
مدـا يتطلـب منــه ضـرورة الموازنـة بـين هـذه

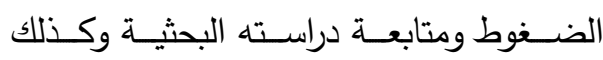
طلابـه، وهذه النتيجـة اتققت مـع دراسـة أحمد حسين (Y ( • (Y)، وهذه من نقاط الضعف في برنـامج الإعـلام التربـوي فيمـا يخـص البحث العلمي والإشراف التي تحتاج إلي تحسين. - لا توجد فروق ذات دلالة إحصائية بين

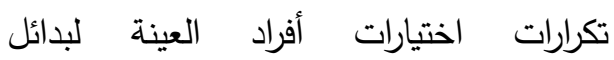
الاستجابات (موافق، موافق إلي حد ما، غير موافق) في العبارتين: r. يوفر القسم الموارد الكافية لتمكن الباحثين من النشاط البحثي. ع. يهتم القسم بمشاركة الباحثين في المشاريح البحثية. حيث تقاربت تكرارات اختيارات أفراد العينة لبدائل الاستجابات وتقاربت النسب المئوية والمتوسطات الحسابية، وجاءت كا' غير دالة إحصائية.

وهذا يعني أن أفراد العينة ليس بينهح فروق حول ضعف الموارد التي تمكن الباحثين من النشاط البحثي، وكذلك ضعف مشاركة الباحثين في المشروعات البحثية بالقسم. - واعتمادا علي المتوسطات الحسابية للعبارات وترتيها كنجد أن العبارة (10) يستفيد القسم من التجارب العالمية في تخصصات الإعلام التربوي جاءت في الترتيب الأول، والعبارة (1) توجد خطة بحثية
العينة (موافقون، موافقون إلي حد مـا) أن هذه النقـاط نقـاط قـوة يتميـز بهـا برنـامج الإعـلام التربوي فيما يخص البحث العلمي والإشـراف وهي تحتاج إلي دعم مستمر • - وجدت فروق لصالح الاختيار (غير موافق)

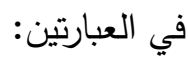
1 إيثـجع القسـم البـاحثين للمشــاركة فـي لـي المؤتمرات. 9 ا ـ تقدم المكتبة خدمات وتسهيلات للباحثين (مواعيـد الـدوام، تــوفير المراجـع، التصــوير ،

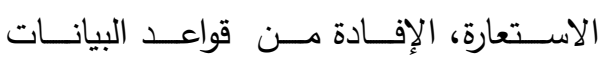
(العالمية). حيث جاءت كاب دالة إحصائية عند (1 •, •)،

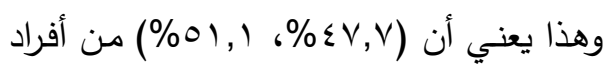
العينة موافقون علي أن القسم العلمي لا يشجع البـاحثين للمشــاركة فـي المـؤتمرات العلميـة

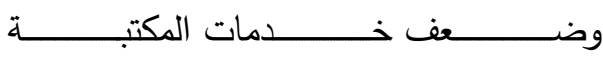
(كالتصوير ،الاستعارة،قواعد البيانـات العالميـة،

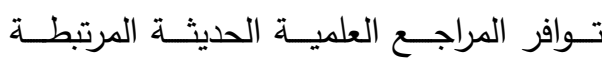
بالتخصص)،فضلا عن أن المشرفين ينشغلون بالتدريس علي حساب البحث العلمي وقد وافق

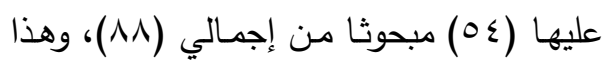
يعني أن عضو هيئة التدريس عليه كثير من من الضــغوط الخاصــة بالتـدريس ســواء لمرحلـة البكـالوريوس أو لمرحلـة الدراسـات العليـا التي دائمـا مـا تشـغله عـن البحـث العلمي والتفـرغ بثـكل كلي لمتابعـة أبحاثه أو أبحـاث طلابـه 
من المشرفين علي الرسائل العلمية في الترتيب الثالث عشر، والعبارة (9 (1) تقدم المكتبة خدمات وتسهيلات للباحثين في الترتيب الرابع عشر، والعبارة (r) يستفيد القسم من نتائج

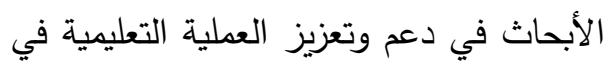

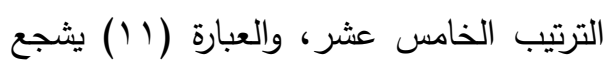
القسم الباحثين للمشاركة في المؤتمرات في الترتيب السادس عشر. ومما سبق يتضح تحقق الفرض الأول جزئيا، حيث وجدت فروق ذات دلالة إحصائية بين تكرارات اختيارات عينة الدراسة علي بدائل

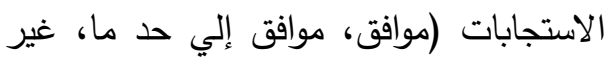
موافق) في استبانه تقويم برامج الدراسات العليا بأقسام الإعلام التربوي. الفرض الثاني:

توجد فروق ذات دلالة إحصائية بين متوسطي درجات الأكور والإناث في استبانه تقويم برامج الاراسات العليا بأقسام الإعلام التربوي علي مستوي الأبعاد والارجة الكلية للاستبانة.

للتحقق من صحة هذا الفرض استخدم الباحث اختبار (ت) للعينات المستقلة ، وتم حساب المتوسطات الحسابية والانحرافات

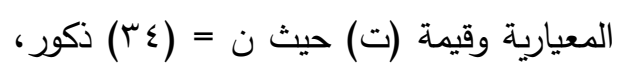

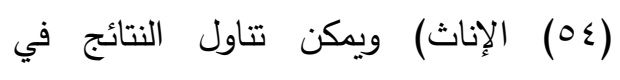

للقسم تتفق مع رؤيته ورسالته وأهدافه في

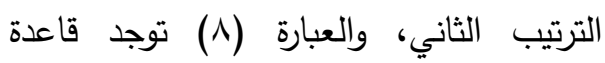
بيانات بالأبحاث ورسائل (الماجستير والدكتوراه) في الترتيب الثالث، والعبارة (ع ( ) بالاني يهتم القسم بالموضوعات البحثية بتخصصات الإعلام التربوي في الترتيب الرابع، والعبارة

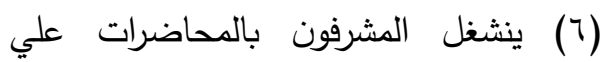
حساب البحث العلمي في الترتيب الخامس، والعبارة (9) يوفر القسم المراجع المتخصصة فئ والحديثة في التخصص في الترتيب السادس، والعبارة (T I) يراعي القسم تخصص الإشراف علي رسائل الماجستير والدكتوراه في الترتيب السابع، والعبارة (Y Y ( ) يشجع القسم الباحثين على الإبداع والابتكار في بحوثهم في الترتيب

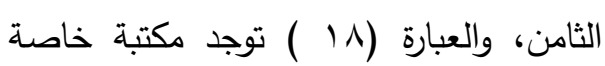
بطلاب للدراسات العليا في الترتيب التاسع، ولتهارة والعبارة (7 (1) يسمح القسم للباحثين باختيار مشرفيهم في الترتيب العاشر، والعبارة (0)

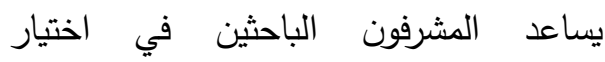
موضوعاتهم البحثية في الترتيب الحادي لئي

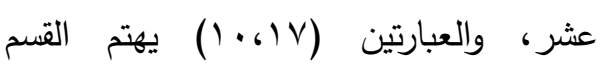

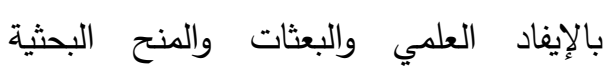
للباحثين، يجيد الباحثين مهارات البحث بالمكتبات وقواعد البيانات العالمية في الترتيب الثاني عشر ، والعبارة (V) توجد متابعة مستمرة الجدول (ror) التالي: 
جدول (ro) اختبار (ت) لالالة الفروق بين متوسطات درجات الأكور والإناث علي استبانه تقويم

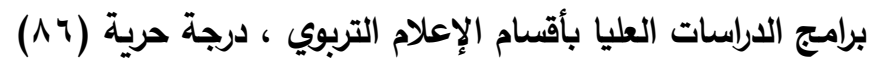

\begin{tabular}{|c|c|c|c|c|c|c|c|}
\hline \multirow{3}{*}{ 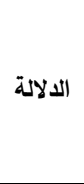 } & \multirow{3}{*}{ ت } & \multicolumn{4}{|c|}{ النوع } & \multirow{3}{*}{ الأبعاد } & \multirow{3}{*}{ p } \\
\hline & & \multicolumn{2}{|c|}{ إناث } & \multicolumn{2}{|c|}{ ذكور } & & \\
\hline & & الانعراف & المتوسط & المعياري & المتوسط & & \\
\hline$\cdot$, Arr & • , Y P & $\Lambda, \vee \backslash 1$ & $\varepsilon \cdot, \ldots$ & Q, & $\leqslant \cdot, \leqslant \leqslant 1$ & برنامج الإعلام التربوي وأهدافه & 1 \\
\hline$\cdot, \leqslant \vee 1$ & $\cdot, \vee \vee Y \varepsilon$ & $0, Y 11$ & $\lceil\wedge, \varepsilon \wedge 1$ & $\curlyvee, \wedge \ldots$ & rq, $\leqslant 11$ & نظام القيد والتسجيل & r \\
\hline . & $1, \ldots 1$ & $V, 99 Y$ & $\varepsilon r, \cdot V \varepsilon$ & $\wedge, \leqslant १ \wedge$ & $\varepsilon r, \wedge \wedge r$ & المقررات الاراسية & $r$ \\
\hline$\cdot,+499$ & $\cdot, q \cdot \varepsilon$ & $0,10 \mathrm{~V}$ & $r v, r \circ q$ & $7, \Gamma 17$ & $r 4, \cdot \wedge \wedge$ & استراتيجيات التعليم والتعلم & $\varepsilon$ \\
\hline$\cdot, q \cdot Y$ & $\cdot, I r r$ & $0, Y \wedge \vee$ & $r_{0,0} \ldots$ & $0, Y Y 0$ & ro,ror & أساليب التقويم & $\circ$ \\
\hline • & 1,017 & $v, 1$ ro & $\leq r, r, r$ & $\vee, \uparrow \wedge r$ & $r q, v ч \varepsilon$ & أعضاء هيئة الترريس & 1 \\
\hline r & 1,017 & $v, 1$ Tro & $\leq r, r, r$ & $\vee, \uparrow \wedge r$ & $r q, v ч \varepsilon$ & البحث العلمي & $v$ \\
\hline$\cdot, \mathrm{v} 01$ & $\cdot, \mu 1 \wedge$ & $\varepsilon r, .9 r$ & $r \leqslant V, V Y r$ & $\leqslant 0, r \leqslant r$ & $r \leq \varepsilon, V \cdot 0$ & الارجة الكلية & \\
\hline
\end{tabular}

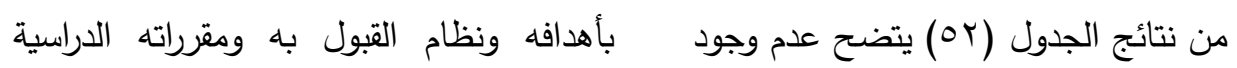

فروق ذات دلالة إحصائية بين أفراد العينة وات واستراتيجيات التعليم والتعلم وأساليب التقويم

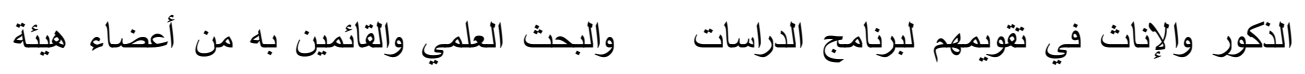

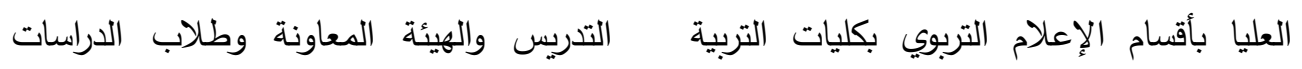

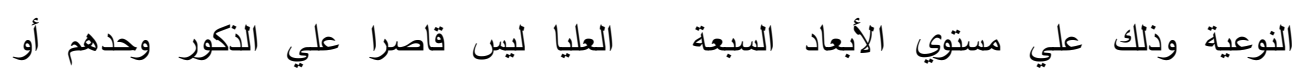

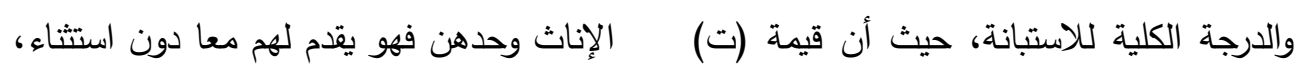

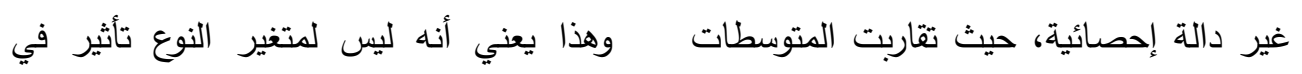

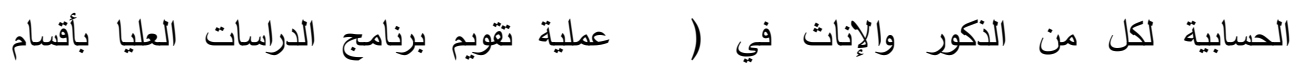
تقويمهم لبرنامج الإعلام التربوي وأهدافه، نظام الإعلام التربوي.

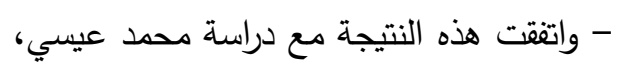

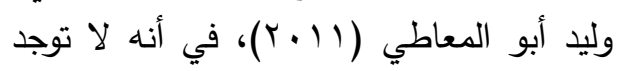
فروق ترجع لمتغير النوع ( ذكور، إناث) بين النين

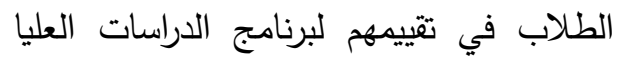

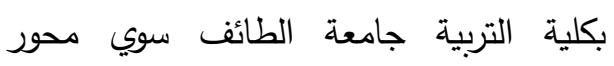

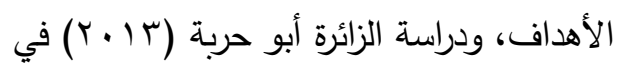
أنه لا توجد فروق ترجع لمتغيري الجنس والتخصص علي استراتيجيات حل المشكلات القيد والقبول والتسجيل، المقررات الدراسية،

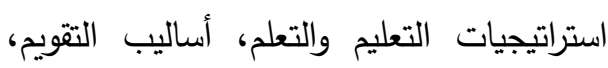

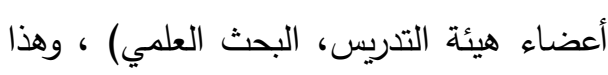

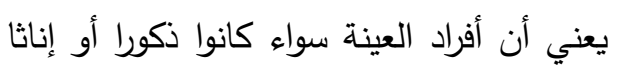
من أعضاء هيئة التدريس والهيئة المعاونة وطلاب الدراسات العليا لا يختلفون في تقويمهح

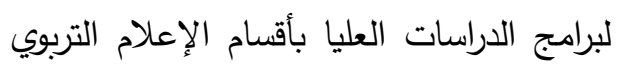
فهم يقومون البرنامج بنفس الدرجة، فالبرنامج 
الإعلام التربوي علي مستوي الأبعاد والدرجة

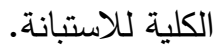

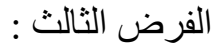

توجد فروق ذات دلالة إحصائية بين متوسطات درجات رتب أفراد العينة (أعضاء

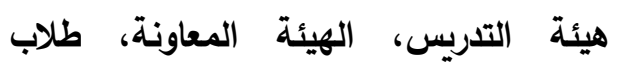
الاراسات العليا) في استبانه تقويم برامج الدراسات العليا بأقسام الإعلام التربوي علي الإئه مستوي الأبعاد والارجة الكلية.

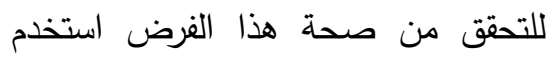
الباحث اختبار تحليل التباين أحادي الاتجاه للعينات المستقلة، وتم حساب المتوسطات المات الدادين

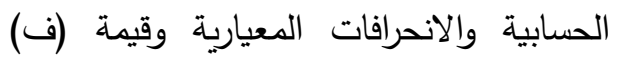
لتحليل التباين أحادي الاتجاه، حيث ن

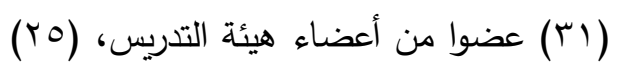

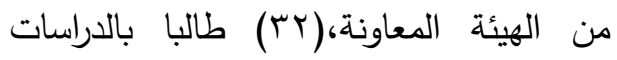

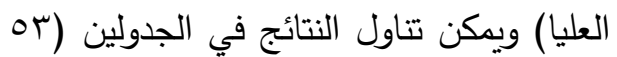
، ع ع م التاليين:
لمواجهة الضغوط النفسية والأكاديمية لطلبة

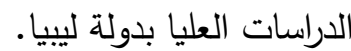
- واختلفت الدراسة الحالية مع دراسة عليان

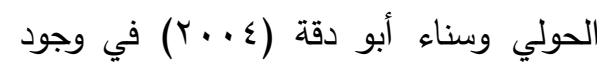
فروق في محور تلبية برامج الدراسات العليا

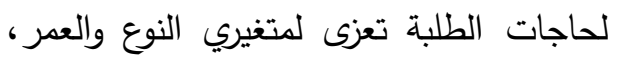

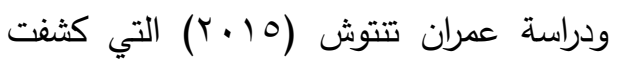
عن أنه توجد فروق ترجع لمتغير نوع العينة في مصادر الضغوط النفسية لطلبة الدراسات

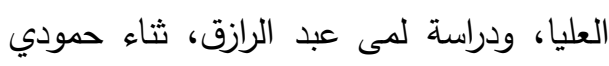

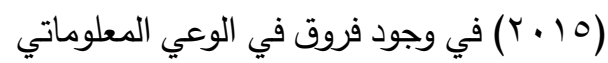
تعود لمتغير الجنس، ودراسة محمد آل سفران

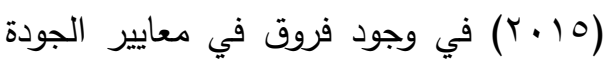
لمتغير النوع لصالح الإناث. ومما سبق يتضح أن هذا الفرض لم لم لإنان يتحقق حيث لا توجد فروق ذات لات دلالة إحصائية بين متوسطي درجات الذكور والإناث في استبانه تقويم برامج الدراسات العليا بأقسام

جدول (ro) المتوسطات الحسابية والانحرافات المعيارية للعينة وفقا للرتبة (أعضاء هيئة التدريس، الهيئة

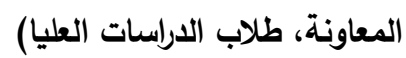

\begin{tabular}{|c|c|c|c|c|c|c|c|}
\hline \multicolumn{6}{|c|}{ الرتبة العلمية } & \multirow{3}{*}{ الأبعاد } & \multirow{3}{*}{ b } \\
\hline \multicolumn{2}{|c|}{ طلاب الدراسات العليا } & \multicolumn{2}{|c|}{ الهيئة المعاونة } & \multicolumn{2}{|c|}{ أعضاء هيئة التدريس } & & \\
\hline المعياري & المتوسط & المعياري & المتوسط & المعياري & المتوسط & & \\
\hline$\Lambda, 09 \leq$ & $r \wedge, 09 r$ & $\Lambda, \uparrow \wedge r$ & $r \Lambda, r r$. & $\Lambda, \Lambda \mid r$ & $\varepsilon r, r q$. & برنامج الإعلام التزبوي وأهدافه & 1 \\
\hline $7,0 \leqslant$ & $r v, v_{0}$. & $\varepsilon, \wedge$ & r^,lr. & $7, .91$ & $r \cdot, 0 \leqslant \Lambda$ & نظام القيد والتسجيل & $r$ \\
\hline$\Lambda, r \backslash 1$ & $\{4,104$ & V,ru. & $r q, \varepsilon \wedge$. & $v, \wedge \cdot 0$ & $\varepsilon 4, .7 \varepsilon$ & المقررات الدراسية & $r$ \\
\hline Y,YYT & $r \Psi, \uparrow \wedge V$ & $0, r \vee 1$ & Y0,9T. & 7,101 & $r V, T / Y$ & استراتيجيات التعليم والتعلم & $\varepsilon$ \\
\hline 0,799 & $r \varepsilon, \Upsilon \wedge V$ & $\varepsilon, 01 Y$ & $r \varepsilon, \wedge \wedge$. & $0, v \bullet \wedge$ & $r q, T V V$ & أساليب التقويم & 0 \\
\hline$V, 0 Y 9$ & $\{\cdot, \varepsilon, 4$ & 7,091 & $\varepsilon \cdot, 94$. & $V, 970$ & $\varepsilon Y, r \wedge V$ & أعضاء هيئة التدريس & 4 \\
\hline$V$, or 9 & $\varepsilon \cdot, \varepsilon \cdot 7$ & 8,091 & $\varepsilon \cdot, 9 \%$ & $V, 970$ & $\varepsilon r, r \wedge V$ & البحث العلمي & $v$ \\
\hline$\varepsilon \&, \leqslant 79$ & $r \varepsilon \cdot, \backslash \wedge V$ & r4,人५q & 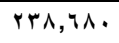 & $\sum \varepsilon, 9+\wedge$ & Y०^,१४V & الارجة الكلية & \\
\hline
\end{tabular}

جدول (؛ ه) تحليل التباين أحادي الاتجاه لدلالة الفروق بين متوسطات درجات رتب أفراد العينة (أعضاء

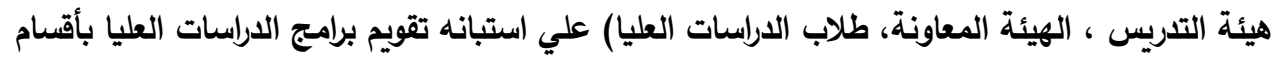

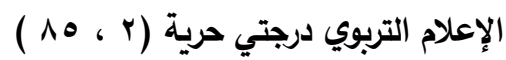




\begin{tabular}{|c|c|c|c|c|c|c|c|}
\hline التأثير & 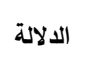 & ف & المربعات & المربعات & مصدر التباين & الأبعاد & م \\
\hline \multirow[t]{2}{*}{$\cdot, \cdot 7 \Lambda$} & \multirow[t]{2}{*}{$\cdot, .0$} & \multirow[t]{2}{*}{$r, \wedge 4$} & rrr, $\leqslant \leq q$ & $\leq \curlyvee 7, \wedge 9 \vee$ & بين المجموعات & \multirow[t]{2}{*}{ برنامج الإعلام التربوي وأهدافه } & \multirow[t]{2}{*}{1} \\
\hline & & & $v 0, T \leq$ & $7 \leq Y 9,0 \leqslant$ & داخل المجموعات & & \\
\hline \multirow[t]{2}{*}{$\cdot, \cdot \leq V$} & \multirow[t]{2}{*}{$\cdot, I Y V$} & \multirow[t]{2}{*}{$r, 110$} & $\vee \cdot, V Y \wedge$ & $1 \leqslant 1, \leqslant 00$ & بين المجموعات & \multirow[t]{2}{*}{ نظام القيد والتسجيل } & \multirow[t]{2}{*}{ r } \\
\hline & & & $r r, \varepsilon \varepsilon$ & $r \wedge \leq r, r r$ & داخل المجموعات & & \\
\hline \multirow[t]{2}{*}{., $1 \cdot 7$} & \multirow[t]{2}{*}{$\cdot, \cdot 1$} & \multirow[t]{2}{*}{$0, \cdot \leq r$} & $r .9,04 r$ & $919,1 \% 0$ & بين المجموعات & \multirow[t]{2}{*}{ المقررات الدراسية } & \multirow[t]{2}{*}{$r$} \\
\hline & & & $71, r q$ & Or $\mid \wedge, r r$ & داخل المجموعات & & \\
\hline \multirow[t]{2}{*}{$\cdot, \cdot 1 r$} & \multirow[t]{2}{*}{$\cdot, O \wedge Y$} & \multirow[t]{2}{*}{$\cdot, 0 \leq 0$} & 19,YTr & 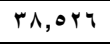 & بين المجموعات & \multirow[t]{2}{*}{ استراتيجيات التعليم والتعلم } & \multirow[t]{2}{*}{$\varepsilon$} \\
\hline & & & ro,rr & $r \ldots, 19$ & داخل المجموعات & & \\
\hline \multirow[t]{2}{*}{$\cdot,+r q$} & \multirow[t]{2}{*}{$\cdot, Y q 1$} & \multirow[t]{2}{*}{1, YOr } & rq,vir & $V \Psi, \varepsilon r V$ & بين المجموعات & \multirow[t]{2}{*}{ أساليب التقويم } & \multirow[t]{2}{*}{0} \\
\hline & & & ५q, Yq & $r \leqslant q \cdot, r q$ & داخل المجموعات & & \\
\hline \multirow[t]{2}{*}{$\cdot,+1 \leq$} & \multirow[t]{2}{*}{$\cdot, 001$} & \multirow[t]{2}{*}{$\cdot, \Delta \wedge \vee$} & rY, \&VA & $7 \leqslant, 900$ & بين المجموعات & \multirow{2}{*}{ أعضاء هيئة التدريس } & \multirow[t]{2}{*}{7} \\
\hline & & & $00, r v$ & $\varepsilon V \cdot \tau, \cdot r$ & داخل المجموعات & & \\
\hline \multirow[t]{2}{*}{$\cdot,+1 \leq$} & \multirow[t]{2}{*}{$\cdot, 00 \wedge$} & \multirow[t]{2}{*}{$\cdot, \diamond \wedge \vee$} & $r_{Y,}, \varepsilon \wedge \wedge$ & $7 \leq, 900$ & بين المجموعات & \multirow[t]{2}{*}{ البحث العلمي } & \multirow[t]{2}{*}{$v$} \\
\hline & & & $\Delta \Delta, r v$ & $\varepsilon V \cdot 7, \cdot r$ & داخل المجموعات & & \\
\hline \multirow[t]{2}{*}{$\cdot,, 04$} & \multirow[t]{2}{*}{$\cdot, 1+4$} & $r, \cdot \leq r$ & $r V I \varepsilon, r I V$ & $V \leqslant r \wedge, \leqslant r r$ & بين المجموعات & الدرجة الكلية & \\
\hline & & & $\wedge \wedge \vee, \wedge r$ & $10 \leqslant 010, Y \wedge$ & داخل المجموعات & & \\
\hline
\end{tabular}

يتضح من نتائج الجدولين السابقين أعضاء هيئة التدريس بما لديهم من رؤية وخبرة

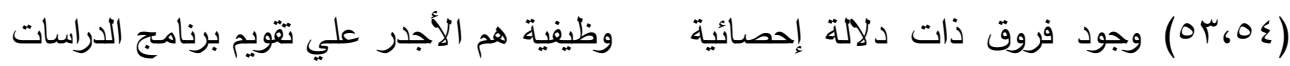

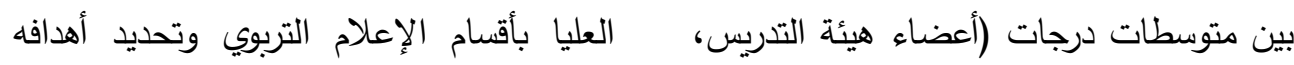

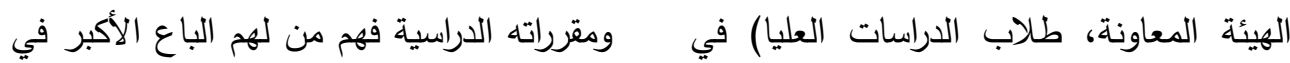

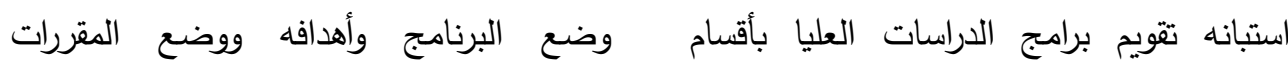

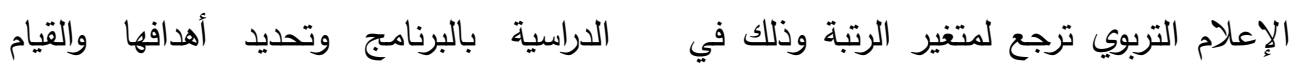

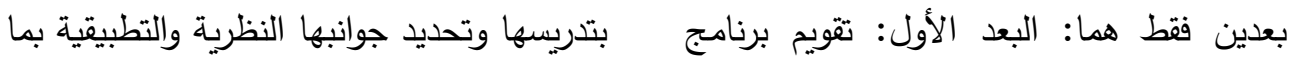

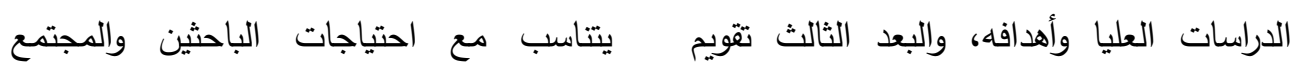

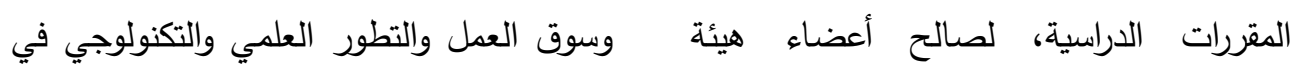

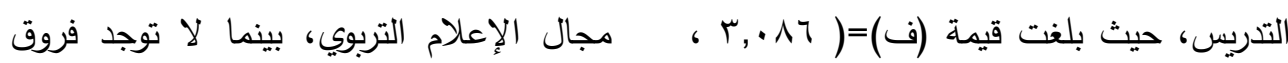

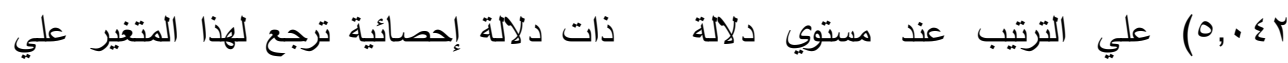

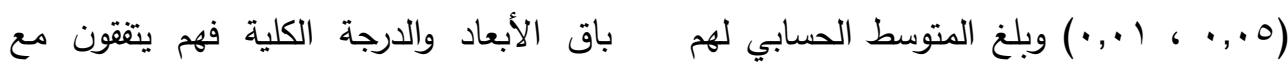

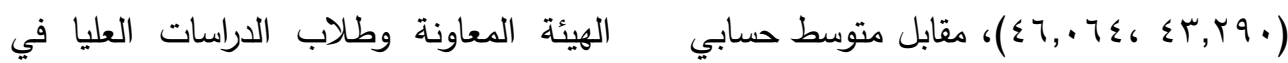

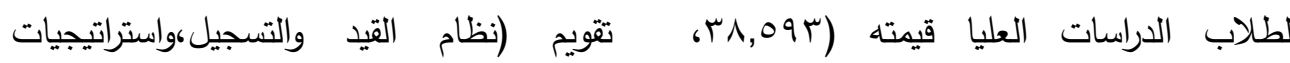

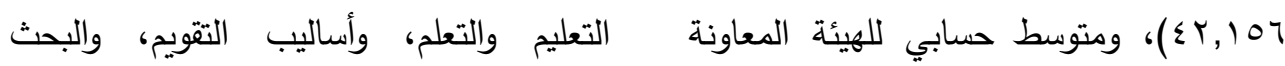

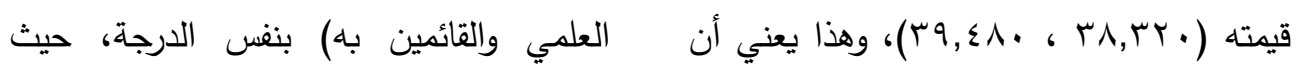


تقاربت المتوسطات الحسابية لهم في هذه الدراسات العليا لهذا البعد حيث تقاربت المتوسطات الحسابية لهم. الأبعاد.

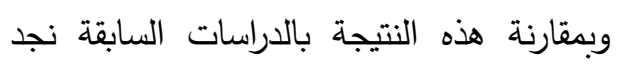

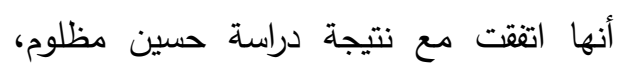

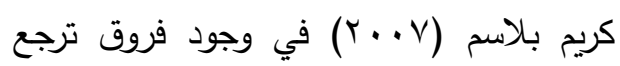

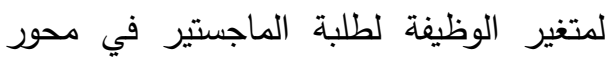
(تلبية البرامج لحاجات الطلبة) دون الدكتوراه،

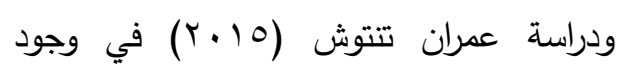
فروق في مصادر الضغوط النفية لطلبة الدراسات العليا ترجع لمتغير الوظيفة. ومما سبق يتضح تحقق الفرض الثاني جزئيا حيث وجدت فروق ذات دلالة إحصائية بين متوسطات درجات (أعضاء هيئة التدريس،

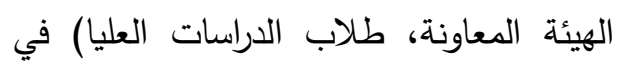
استبانه تقويم برامج الدراسات العليا بأقسام

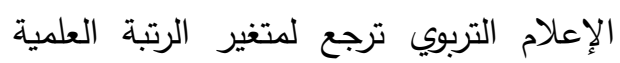

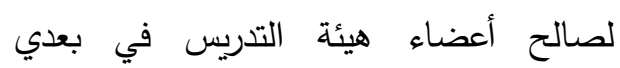

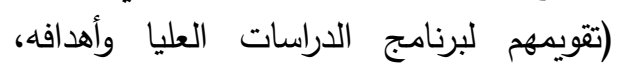

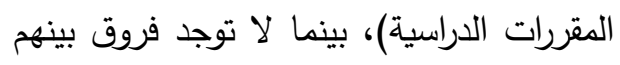

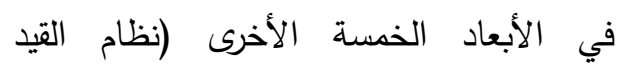

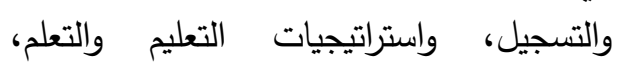
وأساليب التقويم، أعضاء هيئة التدريس، البحث التحثي العلمي) والدرجة الكلية للاستبانة.

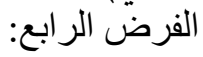

توجد فروق ذات الرابع دلالة إحصائية بين

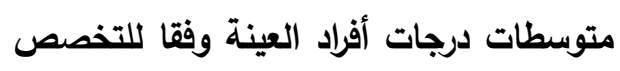
(صحافة، إذاعة وتليفزيون، مسرح تربوي) في استبانه تقويم برامج الإراسات العليا بأقسام الإعلام التربوي علي مستوي الأبعاد والدرجة الكلية للاستبانة.

للتحقق من اتجاه الفروق استخدم الباحث اختبار (LSD) للمقارنات البعدية لتحديد اتجاه الفروق بين كل من (أعضاء هيئة التدريس والهيئة المعاونة، أعضاء هيئة التدريس وطلاب هن التئة الدراسات العليا) في البعد الأول: تقويمهم لبرنامج الدراسات العليا وأهدافه، حيث جاءت الاءت الفروق لصالح أعضاء هيئة التدريس بفرق بين

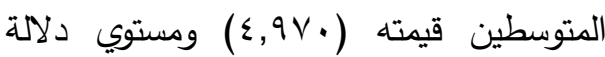
(ד +,.•)، ولصالح أعضاء هيئة التدريس أيضا في تقويمهم لبرنامج الدراسات العليا

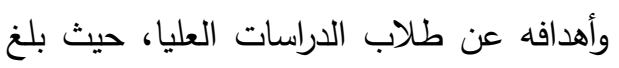
الفرق بين المتوسطين (797, ؟) عند مستوي دلالة (דr.,•)، بينما لا توجد فروق ذات ذات

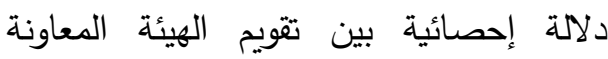

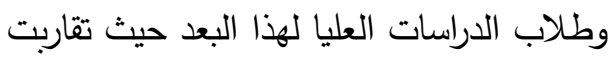
المتوسطات الحسابية لهما. - أيضا وجدت فروق ذات دلالة إحصائية بين

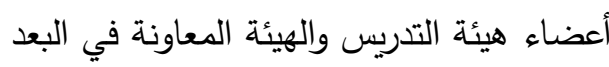
الثالث: تقويم المقررات الدراسية لصالح أعضاء هيئة التدريس بفرق بيم التين المتوسطين قيمته وله ( $)$ ولصالح أعضاء هيئة التدريس أيضا في داندي

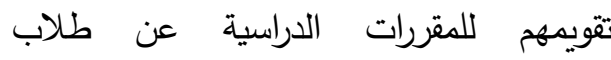
الدراسات العليا حيث بلغ الفرق بين المتوسطين

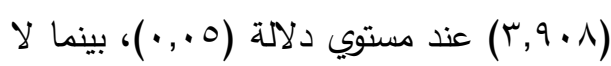
توجد فروق في تقويم الهيئة المعاونة وطلاب 
( § § ) عضوا تخصص صحافة، (9 (1) عضوا للتحقق من صحة هذا الفرض استخدم

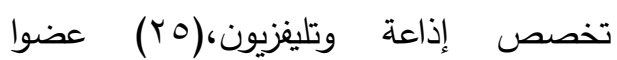
الباحث اختبار تحليل التباين أحادي الاتجاه تخصص مسرح تربوي، ويمكن تتاول النتائج

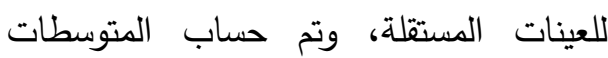
في الجدولين (40،007) التاليين:

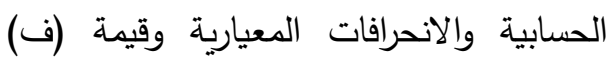
لتحليل التباين أحادي الاتجاه، حيث ن جدول (ه ) المتوسطات الحسابية والانحرافات المعيارية للعينة (صحافة، إذاعة وتليفزيون، مسرح تربوي) وفقا التخصص والاندرات المعيه

\begin{tabular}{|c|c|c|c|c|c|c|c|}
\hline \multicolumn{6}{|c|}{ التخصص } & \multirow[t]{3}{*}{ الأبعاد } & \multirow[t]{3}{*}{ r } \\
\hline \multicolumn{2}{|c|}{ مسرح تربوي } & \multicolumn{2}{|c|}{ إذاعة وتليفزيون } & \multicolumn{2}{|c|}{ صحافة } & & \\
\hline الانحراف & المتوسط & الانعراف & المتوسط & الانعراف & المتوسط & & \\
\hline Q,OrV & rq, 17. & $\neg, \vee \leqslant$. & $\varepsilon \cdot, \wedge 9 \varepsilon$ & $q, \leqslant \vee$. & 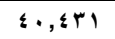 & برنامج الإعلام التربوي وأهدافه & 1 \\
\hline צ, 9ז人 & Ү৭, 1 . & $\varepsilon, \wedge ৭ \wedge$ & $r \wedge, \ldots$ & 0, טצד & $r q, \cdot r r$ & نظام القيد والتسجيل & r \\
\hline$q, T \vee r$ & $\{1,7 \wedge$. & $Y, Y V$. & $\varepsilon r, r q r$ & $\wedge, 1 \uparrow$ & $\varepsilon r,|\wedge|$ & المقررات الدراسية & $r$ \\
\hline$v_{,} \cdot v_{1}$ & $r \bullet, \wedge \ldots$ & $\varepsilon, 1 \%$ & YV, YI. & $0,9 \cdot \varepsilon$ & $r V, r \cdot \varepsilon$ & استراتيجيات التعليم والتعلم & $\varepsilon$ \\
\hline $7,11 \mathrm{r}$ & $r \leq, 1 Y$. & $\varepsilon, \wedge \neg 9$ & YO,OYY & $0, Y Y \leq$ & $r q, 109$ & أساليب التقويم & - \\
\hline $9, \pi 0$. & rq, $\leqslant \varepsilon$. & $ץ, \wedge 91$ & $\varepsilon r, 10 \mathrm{~V}$ & $\vee, r \wedge \vee$ & $\leqslant 1,9.9$ & أعضاء هيئة التدريس & 7 \\
\hline q, ro. & rq, $\varepsilon \varepsilon$. & $r, \wedge q 1$ & $\varepsilon Y, 10 V$ & $\vee, r \wedge \vee$ & $\leqslant 1,9.9$ & البحث العلمي & $v$ \\
\hline or, $\{0 \leq$ & $r r \wedge, \wedge \ldots$ & $r q, \leq q \leq$ & $r \leq q, r)$. & $\leqslant 1,94$. & $r \leq q, \wedge \backslash \wedge$ & الدرجة الكلية & \\
\hline
\end{tabular}

جدول (†ه) تحليل التباين أحادي الاتجاه لالالة الفروق بين متوسطات درجات أفراد العينة وفقا لمتفير التخصص (صحافة، إذاعة وتليفزيون، مسرح تربوي) في استبانه تقويم برامج الدراسات

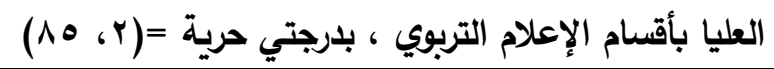

\begin{tabular}{|c|c|c|c|c|c|c|c|}
\hline التأثير & 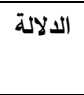 & ف & متوسط المربعات & المربعات & مصدر التباين & الأبعاد & b \\
\hline \multirow[t]{2}{*}{$\cdot, \ldots 4$} & \multirow[t]{2}{*}{$\cdot, \vee \wedge \wedge$} & \multirow[t]{2}{*}{ - } & $19, r \leq 9$ & $r \wedge, \& 9 \wedge$ & بين المجموعات & \multirow[t]{2}{*}{ برنامج الإعلام التربوي وأهدافه } & \multirow[t]{2}{*}{1} \\
\hline & & & $\wedge \cdot, \uparrow \wedge$ & $\neg \wedge \circ \vee, q 0$ & داخل المجموعات & & \\
\hline \multirow[t]{2}{*}{$\cdot, \ldots 4$} & \multirow[t]{2}{*}{$\cdot, \mathrm{\vee} \wedge$. } & \multirow[t]{2}{*}{$\cdot$, ro. } & $\wedge, \vee \backslash \wedge$ & IV, \&०Y & بين المجموعات & \multirow[t]{2}{*}{ نظام القيد والتسجيل } & \multirow[t]{2}{*}{ r } \\
\hline & & & $\Gamma \leq, \wedge q$ & หа४ч, & داخل المجموعات & & \\
\hline \multirow[t]{2}{*}{$\cdot, \cdots v$} & \multirow[t]{2}{*}{$\cdot, \mathrm{V} r \mathrm{~V}$} & \multirow[t]{2}{*}{$\cdot, r \cdot 4$} & $r \cdot, \wedge q r$ & $\approx 1, \vee \wedge \bullet$ & بين المجموعات & \multirow[t]{2}{*}{ المقررات الدراسية } & \multirow[t]{2}{*}{$r$} \\
\hline & & & $\uparrow \Lambda, 1 \wedge$ & OV१०, १ & داخل المجموعات & & \\
\hline \multirow[t]{2}{*}{$\cdot, \cdot 1 r$} & \multirow[t]{2}{*}{$\cdot,+, \wedge$} & \multirow[t]{2}{*}{$\cdot, 0 \ldots$} & $1 V, 799$ & $r 0, r q q$ & بين المجموعات & \multirow[t]{2}{*}{ استراتيجيات التعليم والتعلم } & \multirow[t]{2}{*}{$\varepsilon$} \\
\hline & & & $r_{0, r v}$ & $r \ldots r, r r$ & داخل المجموعات & & \\
\hline \multirow[t]{2}{*}{-, } & \multirow[t]{2}{*}{ • Tru } & \multirow[t]{2}{*}{$1,1+1$} & Tr,YYT & Y & بين المجموعات & \multirow[t]{2}{*}{ أساليب التقويم } & \multirow[t]{2}{*}{ - } \\
\hline & & & rq, rı & $r \leqslant 9 \vee, r ४$ & داخل المجموعات & & \\
\hline \multirow[t]{2}{*}{$\cdot, \cdot r \leqslant$} & \multirow[t]{2}{*}{$\cdot, r \leqslant 9$} & \multirow[t]{2}{*}{$1, .70$} & OA, rrr & 118,748 & بين المجموعات & \multirow[t]{2}{*}{ أعضاء هيئة التدريس } & \multirow[t]{2}{*}{1} \\
\hline & & & $0 \leqslant, \vee 4$ & $\varepsilon Y 0 \leqslant, \mu Y$ & داخل المجموعات & & \\
\hline \multirow[t]{2}{*}{$\cdot, \cdot r \varepsilon$} & \multirow[t]{2}{*}{$\cdot, r \leqslant q$} & \multirow[t]{2}{*}{$1, .70$} & OA, & 117,797 & بين المجموعات & \multirow[t]{2}{*}{ البحث العلمي } & \multirow[t]{2}{*}{ v } \\
\hline & & & $0 \leqslant, V 4$ & \&YO & داخل المجموعات & & \\
\hline
\end{tabular}




\begin{tabular}{|c|c|c|c|c|c|c|}
\hline \multirow[t]{2}{*}{.,.,$r$} & \multirow[t]{2}{*}{$\cdot, 0 \vee r$} & \multirow[t]{2}{*}{., 04} & $1.04, \ldots 4$ & $r 1.4, .1$ & بين المجموعات & \multirow[t]{2}{*}{ الدرجة الكلية } \\
\hline & & & $r \theta, r v$ & $109 \mathrm{Ar}, \mathrm{V}$. & داخل المجموعات & \\
\hline
\end{tabular}

يتضح من نتائج الجدولين السابقين علي تلمية بعض استراتيجيات حل المشكلات

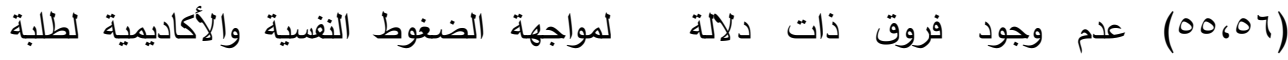

إحصائية بين متوسطات درجات أفراد العينة الدراسات العليا بدولة لليبيا.

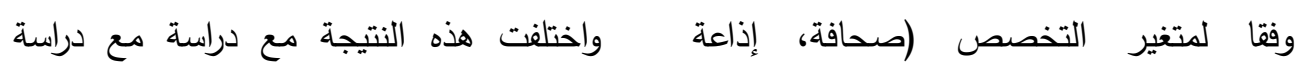

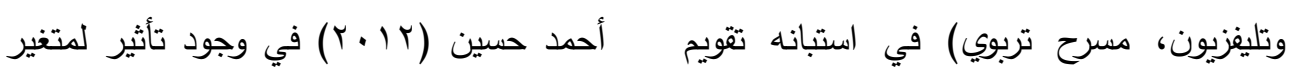

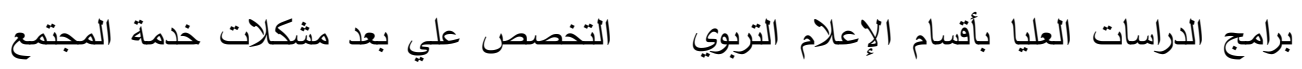

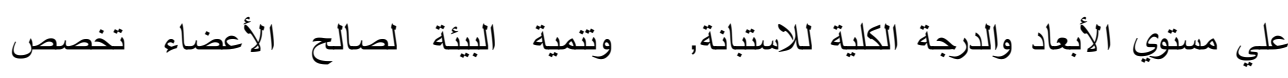

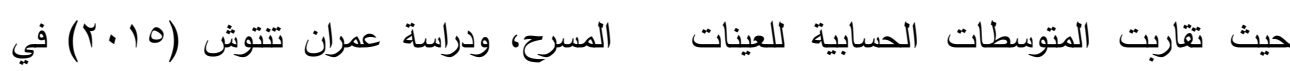
الثلاث في تقويمهم (لبرنامج الإعلام التربوي وجود تأثير لـتغير التخصص ودرسة علي مصات

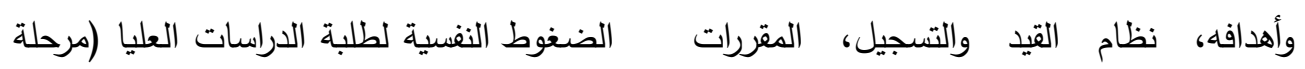

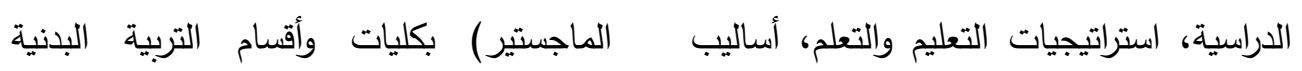
التقويم، أعضاء هيئة التدريس،البحث العلمي) والرياضة بالجامعات الليبية، ودراسة لمى عبدات

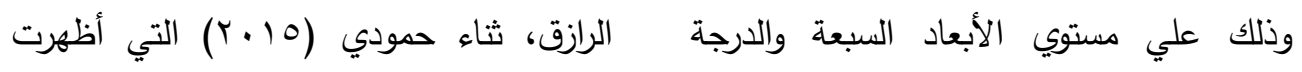
الكلية، حيث تقاربت المتوسطات الحسابية لهم وجود فروق في الوعي المعلوماتي تعود للمتغير لتراه

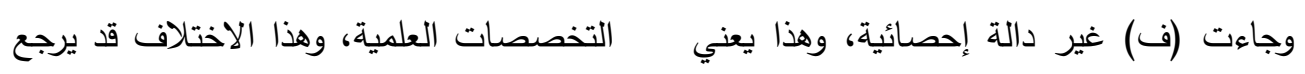

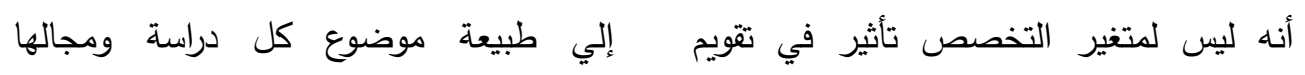

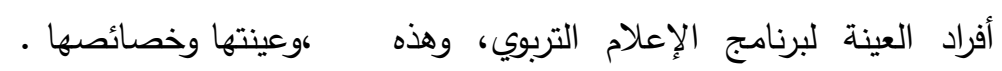

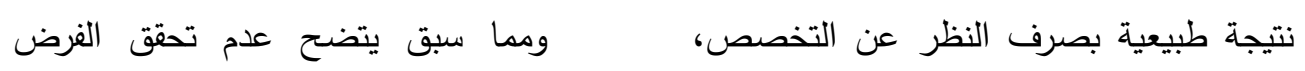

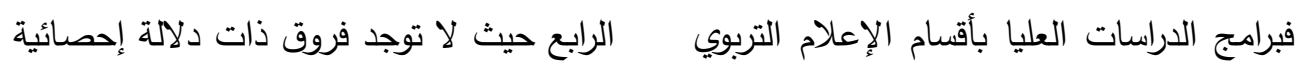

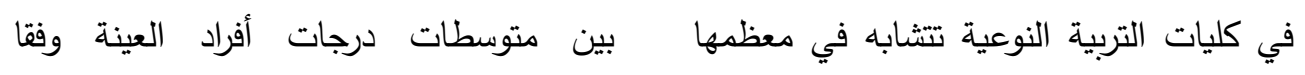

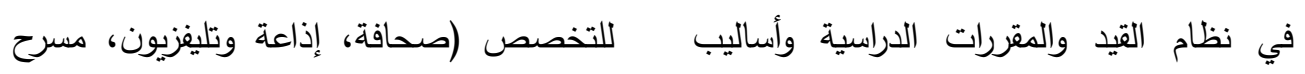
التتريس والتقويم وكذلك في البحث العلمي) تربوي) في استبانه تقويم برامج الدراسات العليا

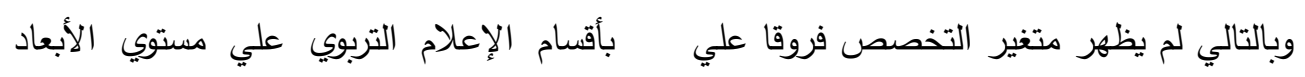

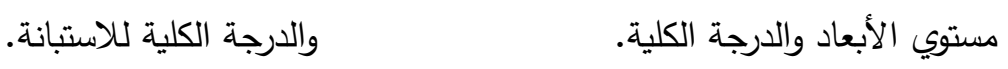

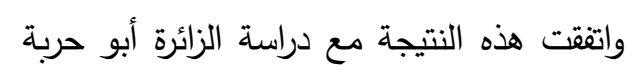

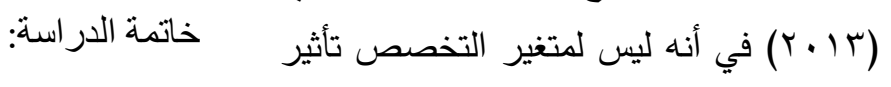


التربية النوعية (الدقي جامعة القاهرة، العباسية

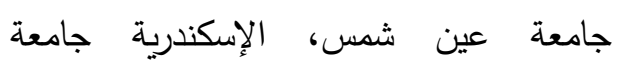
الإسكندرية، أسيوط جامعة أسيوط، الزقازيق

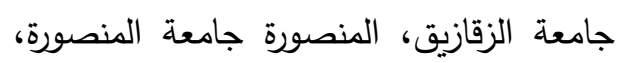

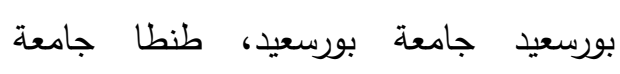

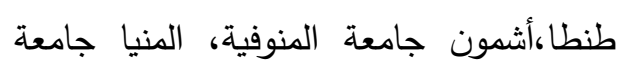

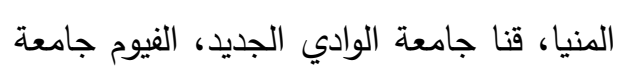
الفيوم، دمياط جامعة دمياط، بنها جامعة بنها، كفر الثيخ جامعة كفر الثيخ، أسوان جامعة أسوان). r. عدد كليات التربية النوعية التي بهان تخصص الإعلام في مرحلة البكالوريوس

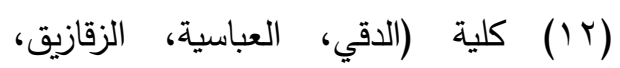
المنصورة، بورسعيد، طنطا، أشمون، المنيا، دمياط، بنها، كفر الثيخ، أسوان).

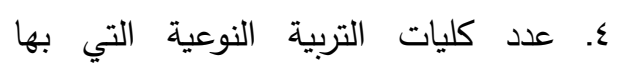
تخصص الإعلام التربوي في مرحلة في مرحلة

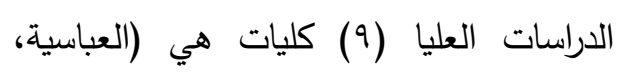
الزقازيق،المنصورة، بورسعيد ،طنطا، أشمون، المنيا، دمياط ، بنها ).

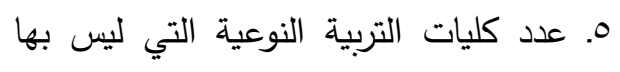
تخصص الإعلام التربوي في في مرحلة

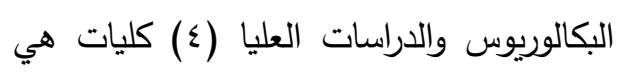
: الإسكندرية، الفيوم، أسيوط، قنا).

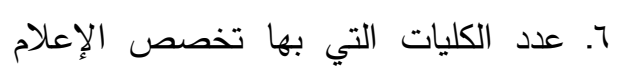
التربوي في مرحلة البكالوريوس دون الدراسات

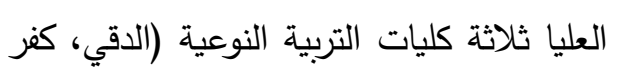

تتاولت الدراسـة تقويم بـرامج الدراســات العليـا بأقسام الإعلام التربوي بكليات التربية النوعية

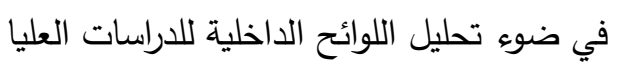
بكليـات التربيـة النوعيـة ورؤيــة أعضــاء هيئسة

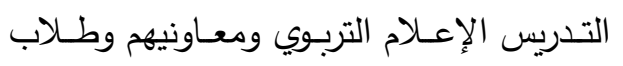

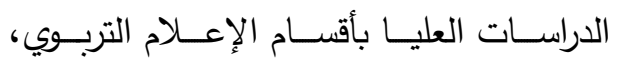

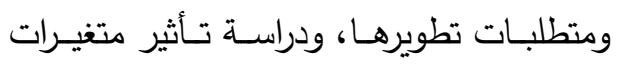

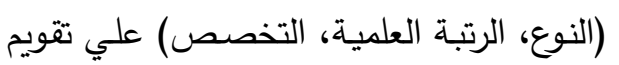

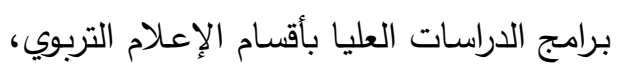

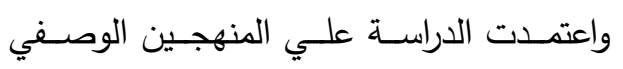

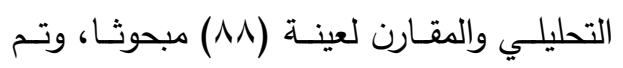
إعـداد أداتـين الأولـي لتحليـل بـرامج الإعـلام

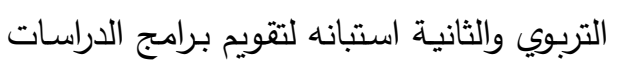

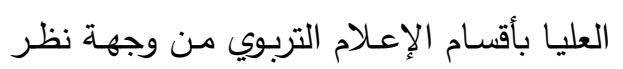
عينة البحث، وتضـنت الاستبانه سبعة أبعاد

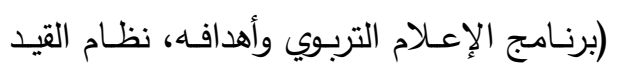

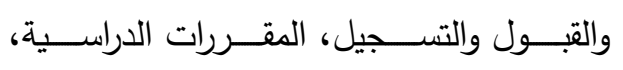

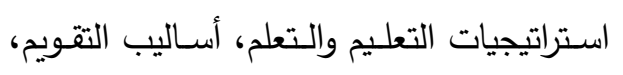

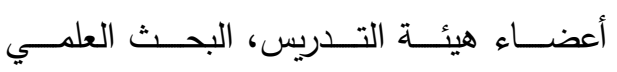
والإشـراف)، وكثفت نتائج الدراسـة التحليليـة عن: ا. كليات التربية النوعية بتخصصاتها المختلفة ليس لها كليات مناظرة علي مستوي العالم العربي والأجنبي. r. عدد كليات التربية النوعية في جمهورية مصر العربية (7 (1) كلية تمثل (7 (1) جامعة حكومية تقع في (10) محافظة، هي كلية 
الكلية لا تقبل إلا من أبناء المحافظة فقط علي مستوي مرحلة البكالوريوس.

9. ومن حيث مدي توافر التخصص العام الإعلام التربوي بالكليات يوجد (9) كليات تراعي التخصص في مرحلتي البكالوريوس بلاعدي

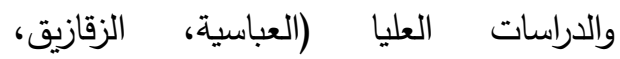

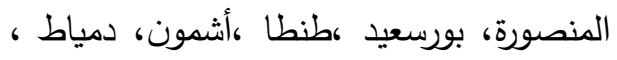
بنها، المنيا) مع الأخذ في الاعتبار أن الدراسة بونة

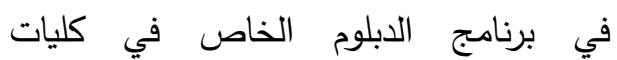
(العباسية، المنصورة، أثمون، دمياط، المنيا) عام، ويتخصص الطالب وفقا لموضوع رسالته. • ا. توجد (ع) كليات تراعي التخصص الدقيق

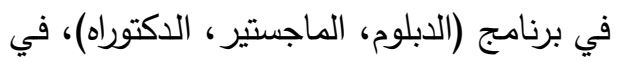

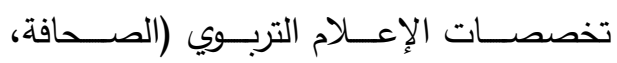

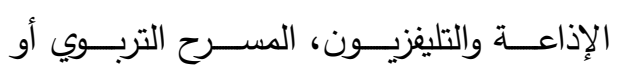
المدرسـي)،هي (الزقــازيق، بورسـعيد، طنطـا، بنها). وتزيــ طنطسا علي هذه البرامج برنـامج العلاقات العامة والإعلان.

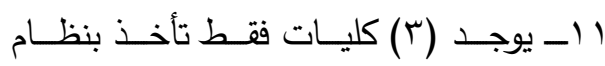
السـاعات المعتمدة في برنامج الدراسات العليا

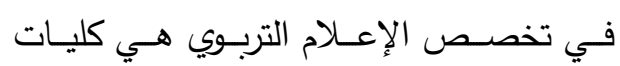
التربية النوعية (الزقازيق، بنها، بورسعيد) بينما توجد (؟) كليـات تكـون الدراسـة بهـا بنظــام (العـام الدراسـي) وهـي كليـات التربيـة النوعيـة

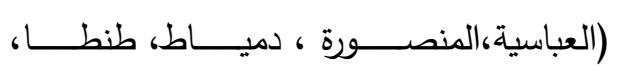
أشمون، المنيا).
الثيخ، أسوان)، وسيتم فتحها بالدقي بداية من

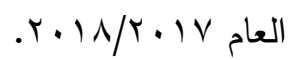
V. عدد الجامعات التي ليس بها كليات للتربية

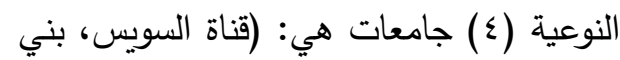
سويف، حلوان، سوهاج). A. من حيث تغطية كليات التربية النوعية لحاجة المحافظات والأقاليم توجد (0) كليات للتربية النوعية في صعيد مصر هي (الفيوم،

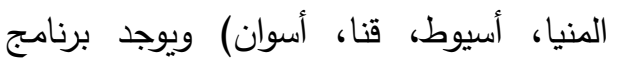
للإعلام التربوي لمرحلة البكالوريوس والدراسات العليا في كلية واحدة فقط وهي (كلية التربية

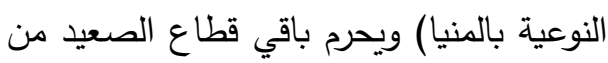

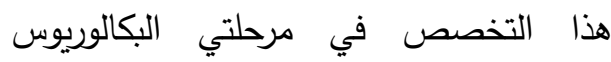
والدراسات العليا، في حين يوجد (^) كليات تغطي حاجة الوجه البحري والدلتا (الإسكندرية، ولان الزقازيق، المنصورة، طنطا، أثمون، دمياط، لفه

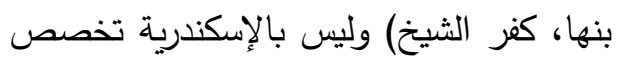

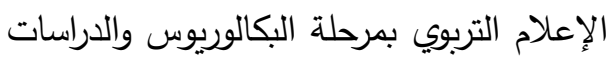
العليا، في حين توجد كلية واحدة فقط هي كلية التربية النوعية ببورسعيد تغطي حاجة محافظة بورسعيد دون مدن محافظات القناة (السويس، الإسماعيلية) ويوجد بها تخصص مد الإعلام التربوي في مرحلة البكالوريوس والدراسات العليا، وهذا غير كاف لسد حاجة الثلاث محافظات لتخصص الإعلام التربوي، خاصة وأن القبول في هذه الكليات إقليمي، بمعني أن 
إلي حد ما في بعض شروط القيد (الدبلوم

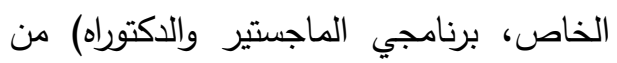
حيث (الحصول علي بكالوريوس التربية النوعية أو الدبلوم الخاص أو الماجستير في

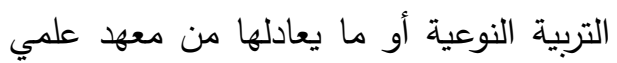
معترف به، وموافقة جهة العمل، وشهادة إتقان

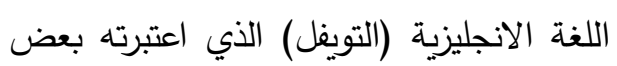
الكليات شرطا للتسجيل والبعض الأخر شرطا للمناقثة، والموقف من التجنيد، وموافقة جهة

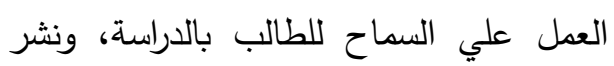

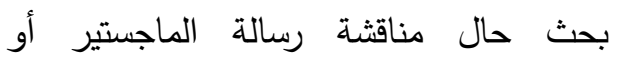
الدكتوراه في مجلة علمية محكمة، وتحديد الحد الأدنى لمناقثة الماجستير (عام) والحد الأدنى فئل لمناقشة الدكتوراه (عامين)، وكذلك إجراءات إلغاء التسجيل للدرجة والمحددة بعد مضي

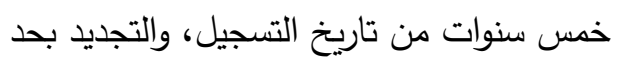
أقص مرتين بعد أخذ رأي لجنة الإشراف وموافقة مجلسي القسم والكلية. 1. اشترطت بعض الكليات القيد لبرنامج الدبلوم الخاص الحصول علي تقدير جيد في مرحلة البكالوريوس علي الأقل، والبعض الأخر تقدير مقبول ككلية التربية النوعية بالزقازيق البكالوريق التوني

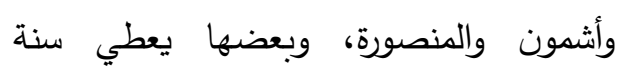

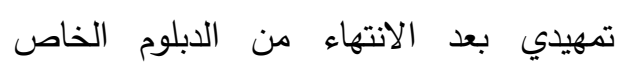
كأشمون وبنها، كما تشترط بعض الكليات قبول الطالب بالدبلوم الخاص بعد نجاحه في امتحان الثفوي والتحريري ويقدر نجاحه بحصوله علي rا. أما فيما يخص تحليل برامج الإعلام التربوي ومقرراته، اختلفت الكليات فيما بينها لتحليا في تتاولها للمقررات ببرامج (الدبلوم الخاص،

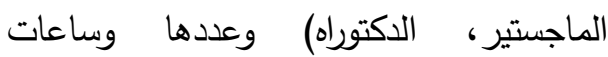
تدريسها النظرية والعملية وتقديراتها ودرجة النجاح فيها، فقد عرض الباحث لبرامج هذه الكليات التسع وانتهي الباحث إلي أن برنامج

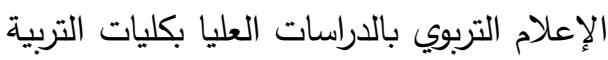
النوعية في حاجة إلي وجود رؤية ورسالة وأهداف إجرائية واضحة، كما تحتاج إلي إلي وجية رؤية ورساله تحسين المقررات وساعات تدريسها مع وجود إستراتيجية للتعليم والتعلم، وإستراتيجية للبحث العلمي معتمدة ومعلنة، وأساليب لتقويم وليني

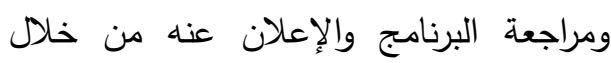
دليل الطالب، والموقع الالكتروني لكل كلية. r اـ لاحظ الباحث وجود تعجل في فتح باب الدراسات العليا في كليات التربية النوعية، علي

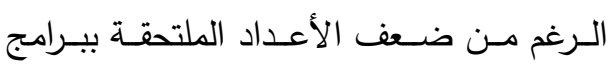
الإعـلام التربـوي التـي لا تتـراوح في برنــامج

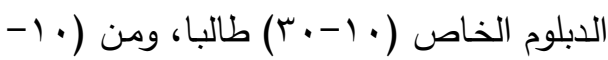
ه 1) طالبـا ببرنـامجي الماجستير والـدكتوراه،

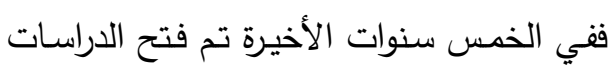

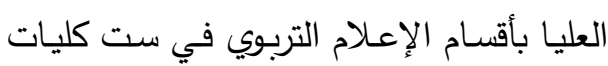

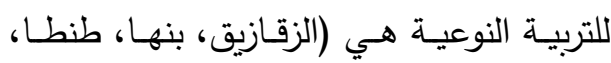
أشمون، بورسعيد، المنيا).

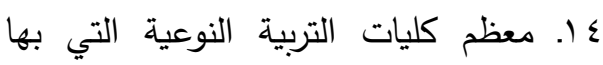
دراسات عليا بأقسام الإعلام التربوي تثابهت 
(\%०\%) من الدرجة وبعض الكليات حددتها المنيا)، والبعض الأخر بنظام الساعات بحصوله علي . ب\% من الدرجة، وكذلك المعتمدة من خلال أربعة فصول دراسية لمدة بعض الكليات تفرض للالتحاق أو القيد عن عامين كما في الزقازيق، وثلاثة فصول دراسية

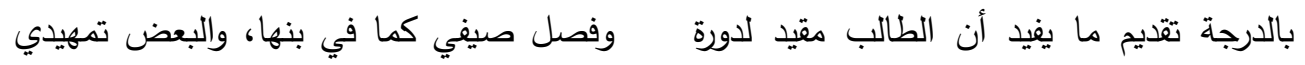

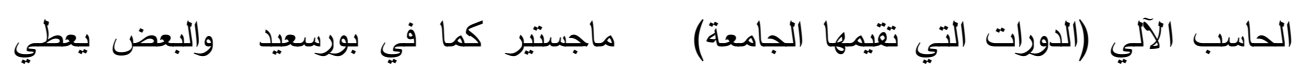

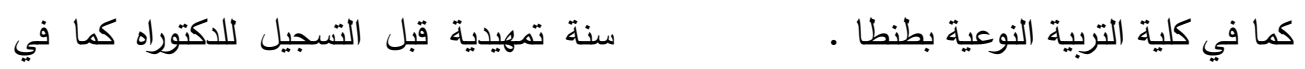

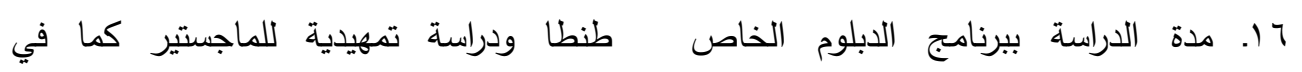
عامين جامعيين في بعض الكليات وثثلاث بورسعيد.

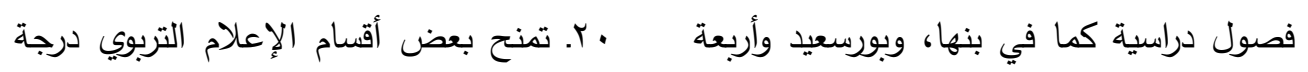

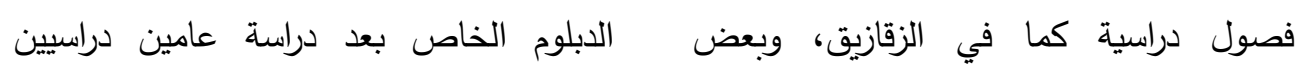

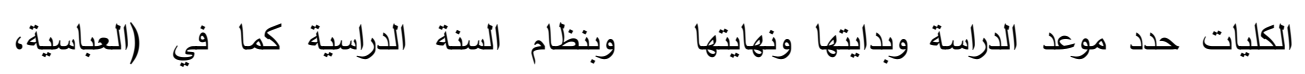

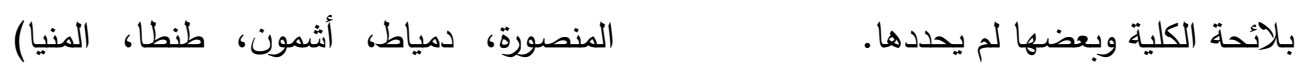
Vا. اتتقت بعض الكليات في منح درجتي وبعض أقسام الإعلام التربوي تمنح درجة

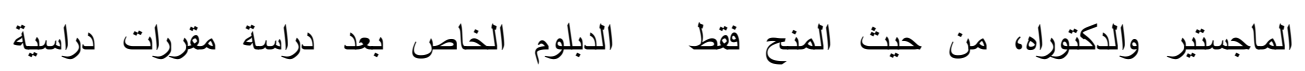

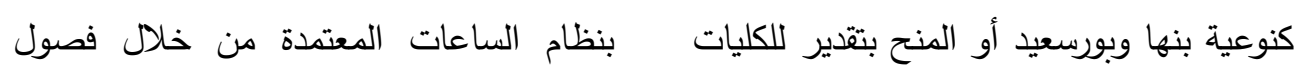

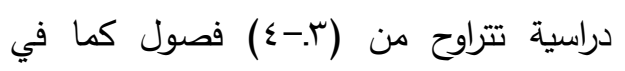

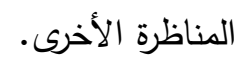
1 ا. اختلفت برامج الإعلام التربوي بين الكليات أقسام الإعلام التربوي بكليات التربية النوعية في عدد المقررات وساعات تدريسها النظرية (بالزقازيق، بنها، بورسعيد).

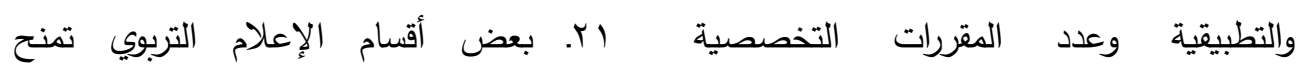

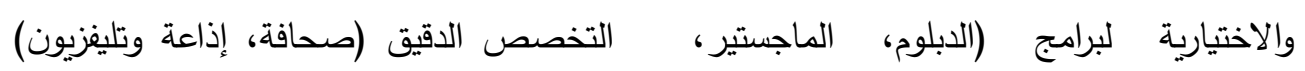
الدكتوراه) وتقديراتها ونسب النجاح فيها، كما بداية من برنامج الدبلوم الخاص كما في كليات

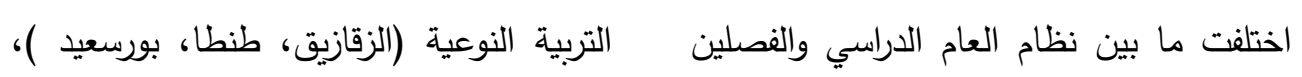
الدراسيين ونظام الثلاث فصول ونظام والبعض الأخر يكون التخصص عام في مجال

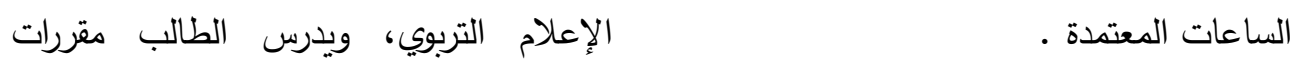
9 ا. بعض أقسام الإعلام التربوي تطبق نظام دراسية في تخصصات الصحافة والإذاعة

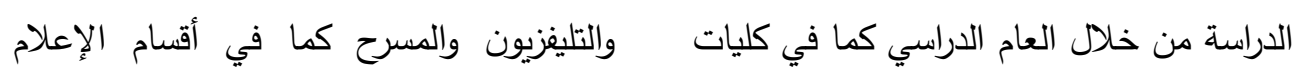
(العباسية، المنصورة، دمياط، أثمون، طنطا، التربوي بكليات التربية النوعية العباسية، 
Tr. عدم وجود رؤية ورسالة وأهداف واضحة

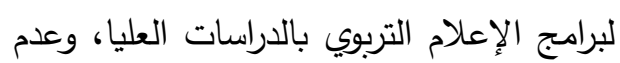

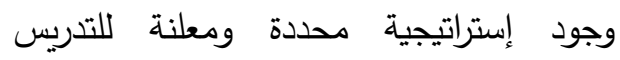
والتعليم والتعلم أو خطة للبحث العلمي وأساليب لتقويم ومراجعة برامج الإعلام التربوي معتمدة ومعلنة لجميع الأطراف المعنية علي الموقع لإعلام لتربوي دعثدة الالكتروني لكل كلية من الكليات حتى وقت لتعن تطبيق الدراسة التحليلية والميدانية، رغم أن معظم أفراد العينة موافقون علي ولتئ وجود إستراتيجية للتدريس والتعليم والتعلم ووجود خطة للبحث العلمي.

• وفيما يخص نتائج الدراسة الميدانية: V V r. كثفت نتائج الدراسة عن وجود نقاط قوة في أبعاد الاستبانه السبعة تحتاج إلي دعم وتطوير مستمر، ونقاط ضعف تحتاج إلي اليتبانه تحسين في كل أبعاد ومحاور الاستبانه. ^ ז. . لا توجد فروق ذات دلالة إحصائية ترجع

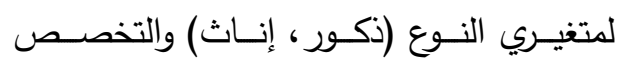
(صحافة، إذاعة وتليفزيون، مسرح تربوي)، في تقـويم بـرامج الدراسـات العليـا بأقسـام الإعـلام

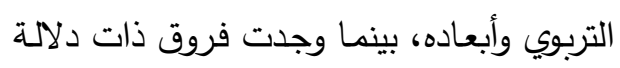
إحصائية بين متوسطات درجات (أعضاء هيئة

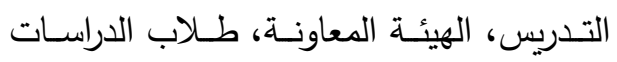
العليا) في استبانه تقويم برامج الدراسات العليا بأقسـام الإعـام التربـوي ترجـع لمتغيـر الرتبـة العلمية لصالح أعضاء هيئة التدريس في بعدين

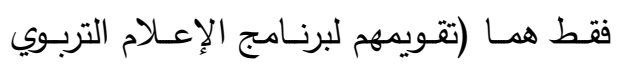

المنصورة، دمياط، أثمون، بنها)، ويتخصص

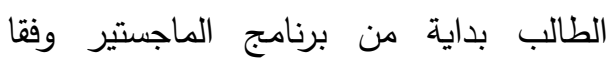
لموضوع رسالته. r r. يوجد تخصص فنون المسرح في برنامج الدبلوم الخاص بكليتي التربية النوعية

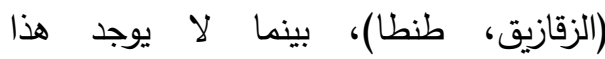
التخصص مطلقا في برنامج الإعلام التربوي

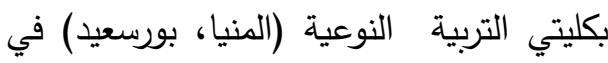
الدبلوم الخاص أو الماجستير أو الدكتوراه.

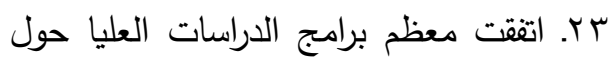
تقديرات النجاح في المقررات الدراسية في لدات لدرات برنامج الدبلوم الخاص أو مقررات الماجستير

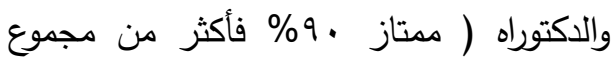

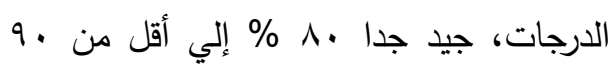

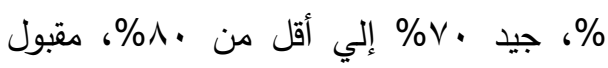

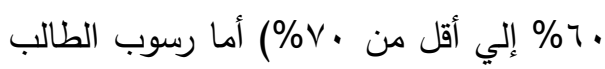

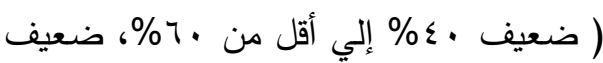
جدا أقل من • § \% من مجموع الدرجات). ع r. بعض الأقسام يعطي سنه تمهيدية لبرنامج

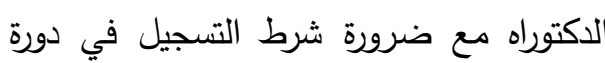
الحاسب الآلي بالجامعة كما في طنطا دون بعض أقسام الإعلام التربوي المناظرة. هr. اتفقت معظم اللوائح علي ألا تقل نسبة الاعلرية حضور الطالب للدحاضرات والدروس العملية عن (\%0\%) وبعضها حددها (\%) لمقررات

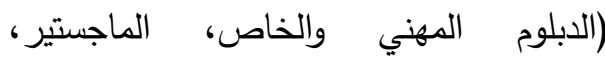
الأكتوراه). 
الامتدادي لتحديد الواقع الراهن للدراسات العليا

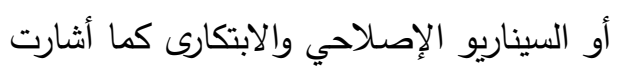

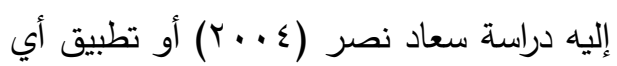

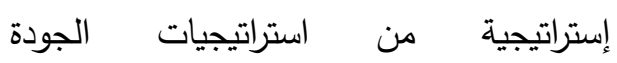
كإستراتيجية six sigma لتحقيق الميزة التتافسية، كما أثارت إليه دراسة علي عبد ربه

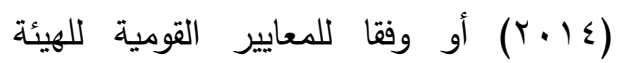
القومية لضمان جودة التعليم والاعتماد المصرية في مجال الإعلام التربوي. r. زيادة القدرة التتافسية بين كليات التربية

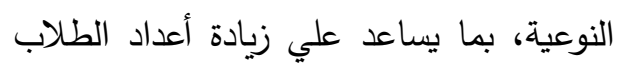
ببرنامج الإعلام التربوي بالدراسات العليا مقارنة

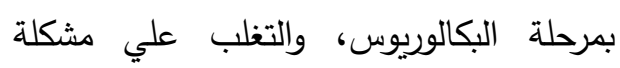
ضعف الأعداد الملتحقين به. r. الاستجابة للتغيرات السريعة واحتياجات لهاته المجتمع وسوق العمل وتوقعات المستقيدين من الانديه الدراسات العليا بأقسام الإعلام التربوي. ثانيا. آليات تطبيق التصور المقترح: ا. تحديد أهداف عامة للدراسات العليا بكليات

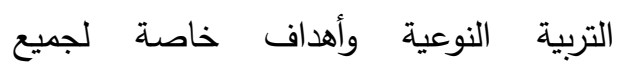
التخصصات بها، ومنها أهداف خاصة لبرامج

$$
\text { الإعلام التربوي. }
$$

r. تحديد الاحتياجات الحالية والمستقبلية للمستقيدين من الدراسات العليا (الطلاب، المجتمع) من خلال استطلاع أرائهج حول هذه الأليات الطناب، الاحتياجات.

ז. التقويم المستمر لبرامج الإعلام التربوي.
وأهدافـه، المقـررات الدراسـية) بينمــا لا توجـــ

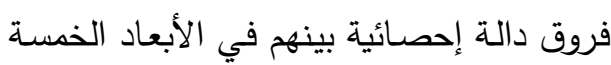

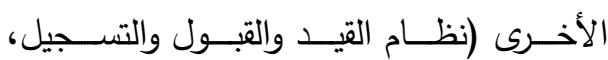

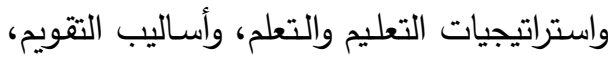
أعضاء هيئة التدري، البحث العلمي) والدرجة الكلية للاستبانة.

ـ ومـن خـلال نتـائج الدراســة الحاليــة ونتـائج الدراسـات السـابقة، يتضـح أن بـرامج الدراسـات

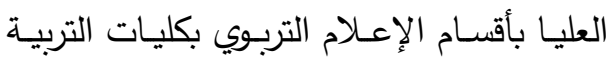

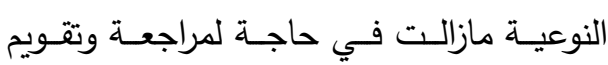

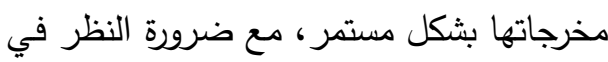
الكم والكيف في قبول الطلاب وإعدادهم، وهذا

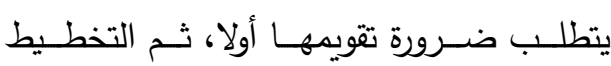
الاستراتيجي الجيد المبني علي التحليل البيئي من أجل تطوير برامجها، بشكل يواكب التقدم العلمسي خاصـة في تحسين (برنـامج الإعـلام

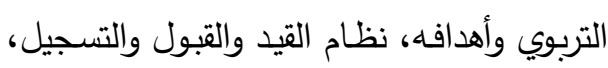
المقررات الدراسية، استراتيجيات التعليم والتعلم،

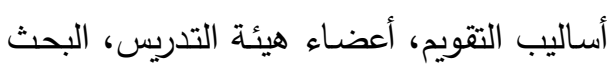
العلمي والإثراف). لذا يضع الباحث التصور المقترح التالي لتفعيل برامج الدراسات العليا بأقسام الإعلام التربوي.

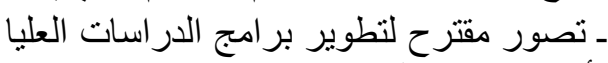

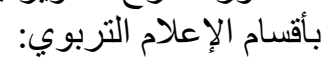
أولا. أهداف التصور المقترح: ا. تطوير برامج الدراسات العليا بأقسام الإعلام التربوي بكليات التربية النوعية، وذلك باستخدام أي سيناريو من سيناريوهات الجودة كالسيناريو 


$$
\begin{aligned}
& \text { r- ضـرورة توصـيف موثق ومعتمـد لبرنـامج } \\
& \text { ثالثا. متطلبات تطبيق التصور المقترح: } \\
& \text { ا. وضع لائحة داخلية موحدة لجميع كليات الإعلام التربوي. } \\
& \text { r. أن يحتوي البرنامج علي مقررات تخصصية. } \\
& \text { تتمي مهارات الباحثين وترتبط بعملهم. }
\end{aligned}
$$

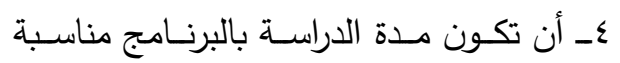

$$
\begin{aligned}
& \text { وكافية. } \\
& \text { ــ المراجعـة المستمرة للبرنـامج مـن مـراجعين } \\
& \text { داخليين وخارجيين. } \\
& \text { 7ـ الاسـتفادة مـن نتـائج المراجعـة الداخليــة } \\
& \text { والخارجية في تطوير البرنامج. } \\
& \text { علي أن تكون أهداف البرنامج: } \\
& \text { • إجرائية وقابلة للقياس. } \\
& \text { ـ تحقق رؤيسة ورسالة وأهداف أقسـام الإعـلام }
\end{aligned}
$$

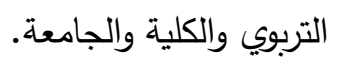

$$
\begin{aligned}
& \text { ـ مبنية علي التحليل البيئي والتحديات الحالية } \\
& \text { والمستقبلية. } \\
& \text { تراعـي التخصصــات الدقيقـة فـي مجــال } \\
& \text { الإعلام التربوي. } \\
& \text { ـ يثـارك في وضعها كافة الأطراف المعنية } \\
& \text { داخل وخارج المؤسسة. } \\
& \text { تلبــي احتياجـات البــاحثين التدريبيـة فــي } \\
& \text { المجالات الصحفية والإذاعية والمسرحية. }
\end{aligned}
$$

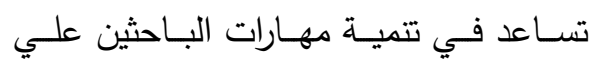

$$
\begin{aligned}
& \text { الابتكار والإبداع. } \\
& \text { ـ تخدم البيئة والمجتمع. } \\
& \text { ـ تواكب التغيرات الجديدة في مجال الإعلام } \\
& \text { التربوي. }
\end{aligned}
$$

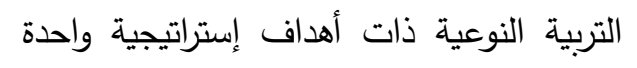

$$
\begin{aligned}
& \text { وذات رؤية ورسالة محددة ومعلنة لكل برنامج } \\
& \text { من برامج الدراسات العليا بها. } \\
& \text { r. تحسين الهيكل التظظيمي للدراسات العليا، } \\
& \text { ورفع مستوى الكفاءة الإدارية للعاملين به. } \\
& \text { r. اختيار القيادات الأكاديمية والإدارية الواعية }
\end{aligned}
$$

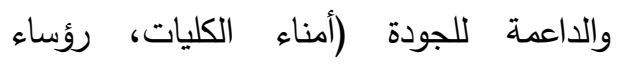

$$
\begin{aligned}
& \text { الأقسام، الوكلاء، العداء) والتي تثجع علي } \\
& \text { الابتكار والإبداع. } \\
& \text { عـ معرفـة احتياجـات العمـلاء والمستتيدين من الإن } \\
& \text { الدراسـات العليـا ومتطلبـات سـوق العملـ، مـن } \\
& \text { خلال استطلاع رأيهم حول هذه الاحتياجات، } \\
& \text { وقياس رضاهم عنها. } \\
& \text { ه. الاستفادة من الكوادر الأكاديمية من أعضاء رضاء } \\
& \text { هيئة التدريس ومعاونيهم بالكليات، والحاصلين }
\end{aligned}
$$

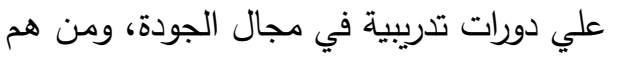

$$
\begin{aligned}
& \text { مراجعون بالهيئة القومية لضمان جودة التعليم } \\
& \text { والاعتمـاد ليكونوا رؤسـاء فرق لمعايير (القدرة } \\
& \text { المؤسسية، الفاعلية التعليمية). } \\
& \text { ـ علي أن تتضـن متطلبات التصـور المقترح }
\end{aligned}
$$

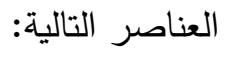

$$
\begin{aligned}
& \text { أ. برنامج الإعلام التربوي وأهدافه: }
\end{aligned}
$$

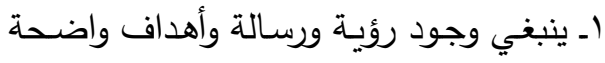

$$
\begin{aligned}
& \text { ومعلنة لبرنامج الإعلام التربوي. }
\end{aligned}
$$


التربية النوعية، وجعل نظام التويفل شرطا للمناقثة في كل الكليات وليس شرطا للتسجيل كما في بعض الكليات. با. فتح باب الالتحاق بالدراسات العليا بأقسام الإعلام التربوي للحاصلين علي كليات الإعلام

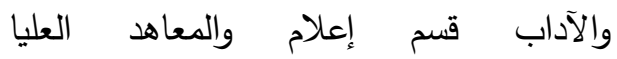

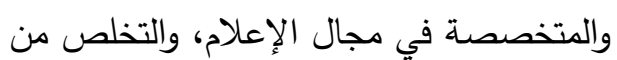
الروتين الإداري بزعم أن هؤلاء غير حاصلين

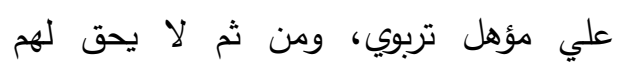
الحصول علي دبلوم أو ماجستير أو دكتوراه الإعلام التربوي، مع تحميلهم بعض المقررات،

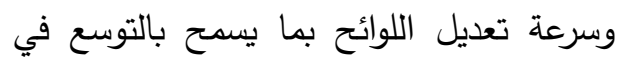
القبول والتغلب علي مشكلة ضعف الالتحاق

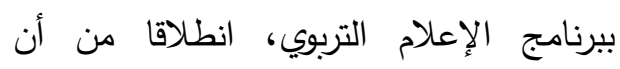
الدراسات العليا وفتحها للمصريين والوافدين العردين مورد لتمية الكلية ذاتيا، بما ينعكس علي لئي الخدمات المقدمة للطلاب.

1. توحيد نسب حضور الطلاب بالدبلوم الخاص فبعض الكليات حددت ذلك بنسبة

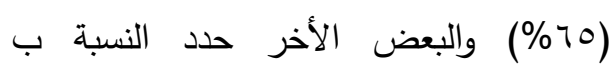

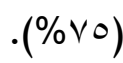

1. توحيد تقديرات الحصول علي الدرجة

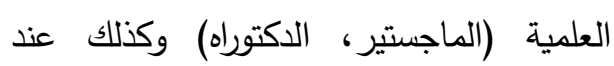
دراسة مقررات (الدبلوم الخاص، الماجستير، لمكتواه وكلئ الاكتوراه).
ـ يعلن عنهـا من خـلال (الموقع الالكتروني للكلية، لوحات، دليل الطالب، مطويات). ب ـ نظام القيد والقبول والتسجيل بالبرنامج:

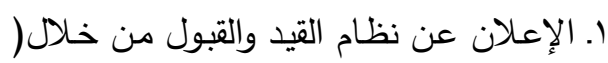
دليل للطلاب، الموقع الإلكتروني) لكل كلية. r- وجـود دليـل إرشـادي (ورقي، الكترونـي) يساعد في عملية القيد والتسجيل . r. المراجعة الدورية والتحديث لإجراءات القيد والتسجيل والإشراف. ع. أن تتم إجراءات القيد والتسجيل بشكل الكتروني والتخلص من عبء الكم الورقي.

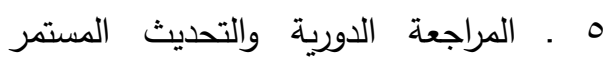

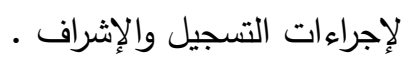
T. الإعلان عن نظام إلغاء القيد والانسحاب والتحويل. V. توافر قاعدة بيانات بأعداد الدبلومات والدرجات العلمية الممنوحة. ^. توافر معايير محددة ومعلنة علي موقع الكلية باختبارات قبول الطلاب وما يتم لتعائ

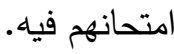
9. إيجاد أساليب للتسويق والترويج لبرامج الإعلام التربوي. • أ. استحداث برامج جديدة وفقا للمتغيرات. ا ا. وجود قواعد منظمة لقبول الطلاب الوافدين والإعلان عنها علي موقع الكلية. r ا. توحيد شروط القيد والتسجيل والانسحاب والتويفل والرسوم الدراسية علي مستوي كليات 


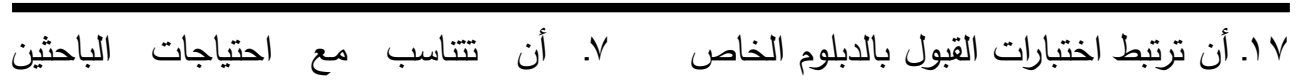

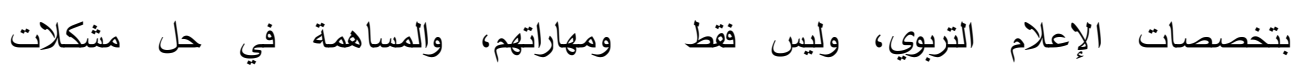

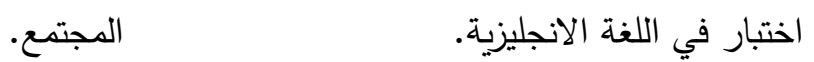

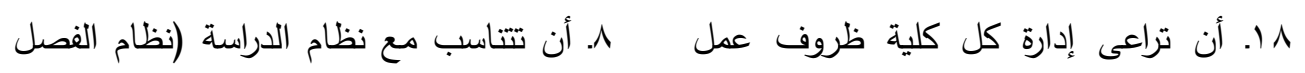
الباحثين عند إعداد الجداول الدراسية خاصة الدراسي، العام الدراسي). وأن معظم الملتحقين أصحاب وظائف ومهن 9. وحرف. التكرار في ضوء نتائج تقويم الباحثين. 9 ا. وضع آلية لتحليل تتاقص أعداد الباحثين .. أن تساعد المقررات في التطور المهني

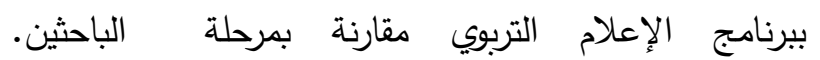
ا ا. توحيد المقررات الدراسية ببرنامج الدراسات

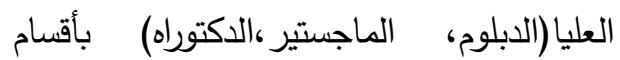
البكالوريوس. ا. ينبغي أن تحقق مقررات الدراسات العليا الإعلام التربوي

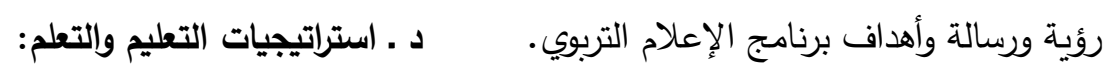
r. أن تكون المقررات ذات أهداف واضحة ا.ـ وضع إستراتيجية للتعليم والتعلم تحقق رؤية

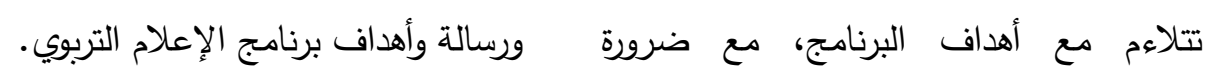

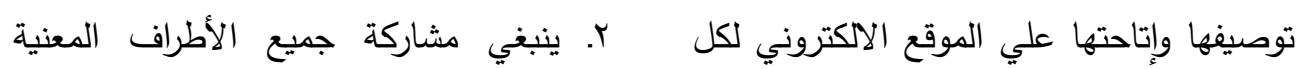
كلية. الألمضاء ، الباحثين) في إعدادها.

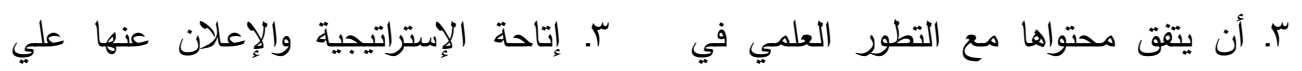

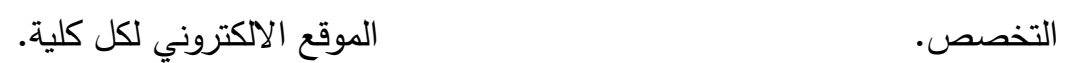

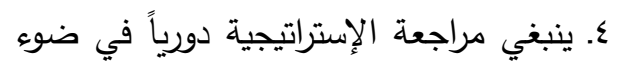
نتائج (الامتحانات، استقصاء الباحثين وأعضاء هيئة التدريس ومعاونيهج)، والاستفادة من نتائج مراجعتها في التدريس. ع. مراعاة التوازن في الجوانب العملية والنظرية، وعددها وساعات تدريسها. 0. مراعاة التوازن في عدد عداعات المقررات التخصصية والتربوية. 0. أن تراعى استراتيجيات التدريس قدرات الباحثين وخصائصهم. ד. ينبغي توافر المواد التعليمية (المعامل، الوسائل والمعينات التعليمية) لتدريسها.

7. الاعتماد علي أنماط من التعلم غير تقليدية

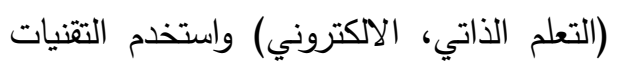




$$
\begin{aligned}
& \text { •. أن تكون اختبارات القبول (التحريرية } \\
& \text { والثفوية) ذات معايير محددة وموحدة ومعلنة. } \\
& \text { و ـ أعضاء هيئة التدريس: }
\end{aligned}
$$
r. المشاركة في (الخطة البحثية للقسم، أنشطة خدمة المجتمع وتتمية البيئة، أنشطة الجودة). r. الحرص علي طيب العلاقة مع الزملاء والرؤساء، وضرورة التواصل مع الباحثين. ع. توجيه الباحثين للمراجع العلمية والإفادة من لن النين خدمات الانترنت وقواعد البيانات المحلية والعالمية، وتثجيع الباحثين علي التعليم

$$
\text { والبحث العلمي والابتكار . }
$$

ه. اختيار أعضاء هيئة التدريس المؤهلين للتدريس والإشراف على طلاب الدراسات العليا

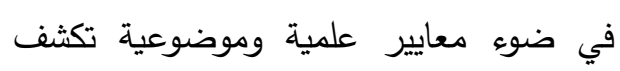
عن كفاءتهم العلمية والبحثية والأكاديمية

$$
\text { للعمل. }
$$

T. تحسين العائد المادي لأعضاء هيئة التدريس بصفة عامة، ونظير الإثراف ومناقشة

$$
\text { الرسائل العلمية. }
$$

$$
\begin{aligned}
& \text { الحديثة في التدري، وعدم الاعتماد علي }
\end{aligned}
$$

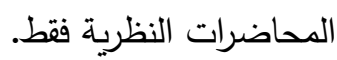

$$
\begin{aligned}
& \text { V. أن يوفر القسم إمكانيات للتدريب (مسرح، }
\end{aligned}
$$

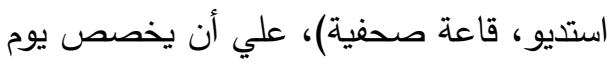

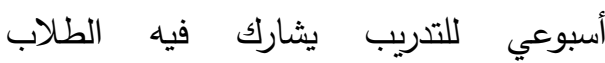
(بالمدارس، المسارح، المؤسسات الصحفية • مالإذاعية)

ـ. توفير الإمكانيات المادية بقاعات التدريس والسيمنار العلمي من أجهزة كمبيوتر وشاشات الإنيات عرض وخطوط انترنت لتسهيل عملية التدريس، وإعداد وتقديم البحوث العلمية.

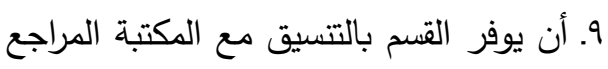

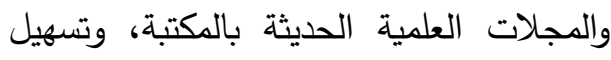
عملية البحث والإطلاع والاستعارة والتصوير والاستفادة من قواعد البيانات المصرية والعربية والعالمية، وبنك المعرفة المصري. هـ ـ أساليب التقويم: ا. ضرورة التقويم المستمر لبرنامج الإعلام التربوي من خلال قياس رضا الباحثين عنه.

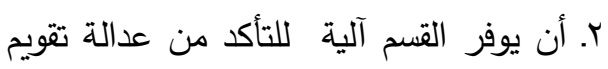
الباحثين (الممتحن الخارجي، اللجان الثلاثية). علي أن يتم إعلام الباحثين بنتائج التقويم. r. الاستفادة من تحليل نتائج تقويم الباحثين في لني تطوير البرنامج ومقرراته. ع. ينبغي أن تركز أساليب التقويم علي المهارات المعرفية والمهارية والسلوكية. 
التسجيل، كما في كلية التربية النوعية بالمنصورة وكليات مناظرة تعتبر ذلك تغييرا جديدا من تاريخ موافقة مجلس الدراسات العليا بالجامعة. م. مراعاة التخصص في لجان الإشراف والمناقشة، ومشاركة الباحثين في اختيار مشرفيهم. 9. توفير المراجع الحديثة في التخصص مع ضرورة توفير التسهيلات والخدمات للباحثين بمكتبة كل كلية من حيث (مواعيد الدوام،

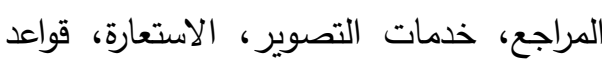
البيانات).

•. . ضرورة إعداد برامج تدريبية لطلاب الدراسات العليا للاستفادة من( مهارات استخدام الكمبيوتر، الإنترنت، البريد الإلكتروني، مراكز

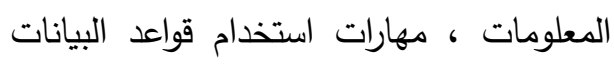
العالمية، قواعد البيانات المصرية والعربية، وبنك المعرفة المصري، مهارات البحث العلمي

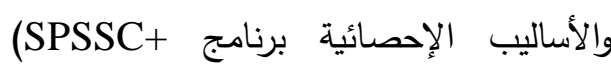
وتوظيفها في خدمة أبحاثهم العلمية ولتخفيف باليف الأعباء المالية عنهم وعن أسرهم والاعتماد

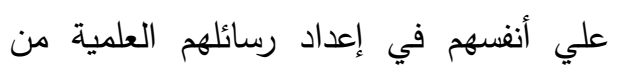
خلال ورش عمل أو من خلال مراكز الخدمة بكل كلية. 11. إجراء البحوث التجريبية علي طلاب الدراسات العليا في مجال الإعلام التربوي

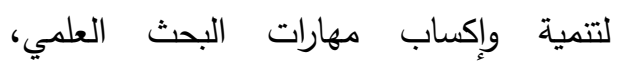

\section{ز ـ البحث العلمي والإثراف:}

ا. تفعيل وجود الخطط البحثية في التخصص والإعلان عنها علي الموقع الالكتروني لكل كلية. r. ينبغي توفير موارد كافية لتمكن الباحثين وطلاب الدراسات العليا من النشاط البحثي. r. تعظيم الاستفادة من نتائج الأبحاث العلمية في دعم وتعزيز العملية التعليمية، والمساهمة التاتجة في حل مشكلات المجتمع. ع. . ينبغي إشراك طلاب الدراسات العليا في المشروعات البحثية والاهتمام بالمنح والبعثات والإيفاد العلمي، وتثجيع الباحثين للمشاركة في المؤتمرات والندوات العلمية والمحافل العلمية. 0. مساعدة المشرفين للباحثين في اختيار بحوثهم وفق الخطط البحثية للقسم والتواصل المستمر معهم. 7. توافر قاعدة بيانات الكترونية بالإنتاجية العلمية لأعضاء هيئة التدريس والأبحاث العلمية ورسائل الماجستير والدكتوراه في مجال الإعلام التربوي، لتسهيل عملية البحث والإطلاع ولتكون بمثابة دليل للباحثين لانتقاء أفكار وموضوعات البحوث التي تخدم البيئة والمجتمع، مع الاهتمام بمهارة عرض نتائج البحوث وكتابة التقارير للدراسات السابقة.

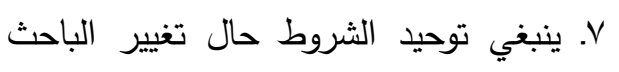
لموضوع بحثه تغييرا شاملا أو جزئيا حيث توحيث

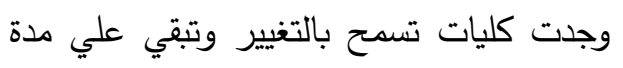




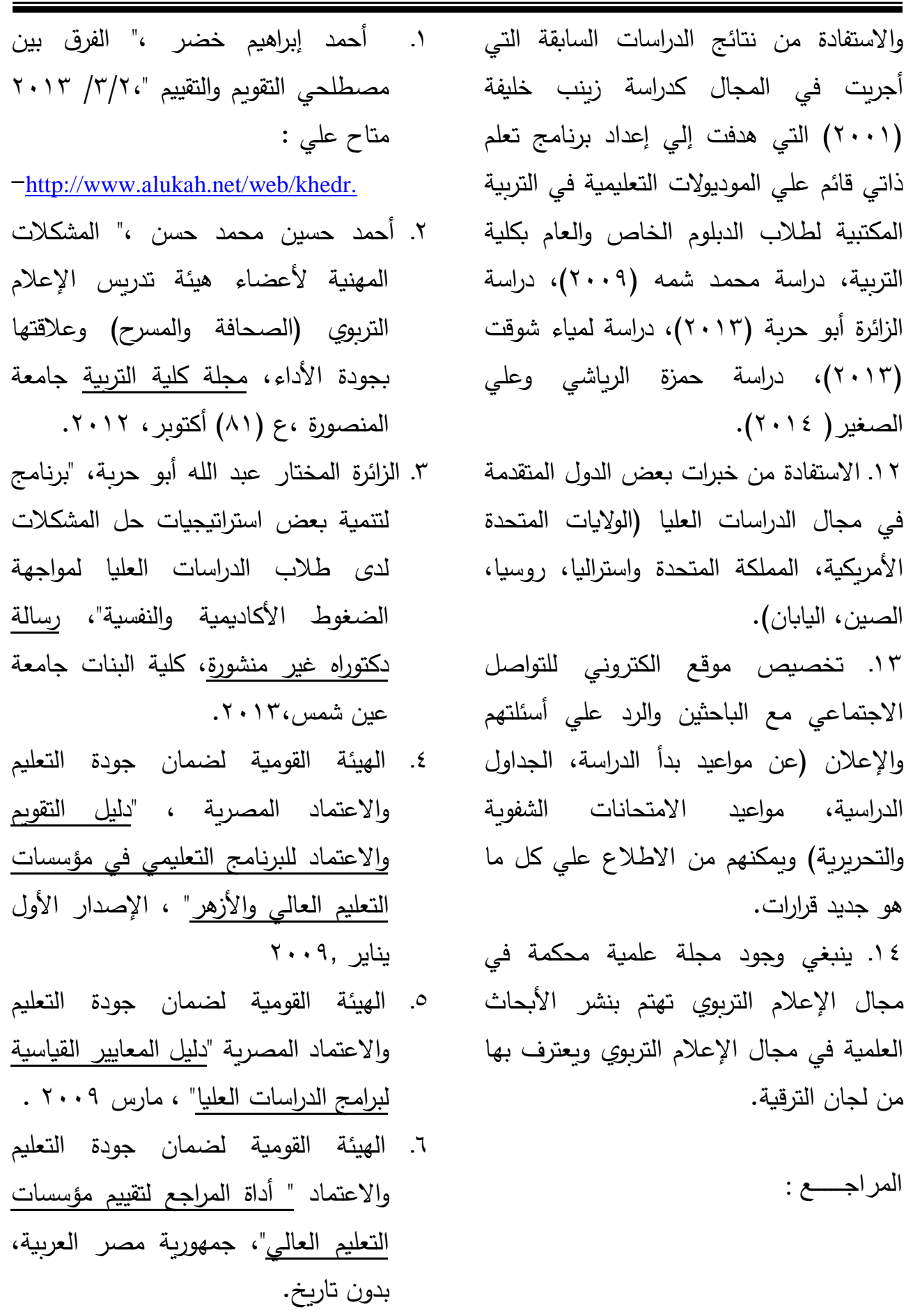




\begin{tabular}{|c|c|}
\hline 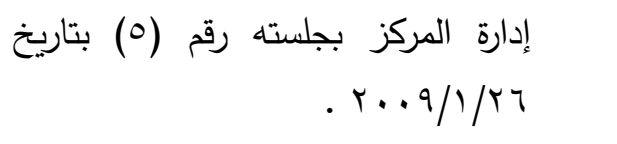 & تقويمية ألدراسات العليا في مجال الكنيسي، دراسة \\
\hline 11. تقرير المجلس القومي للتعليم والبحث & الخاصة بكليات التربية في ضوء \\
\hline العلمي والتكنولوجيا ،الدورة سب . & الاتجاهات العالمية المعاصرة"، رسالة \\
\hline 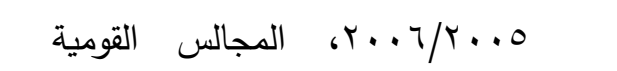 & دكتوراه غير منشورة ، كلية التربية جامعة \\
\hline 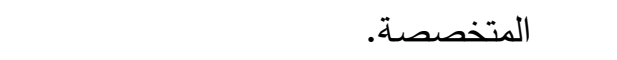 & 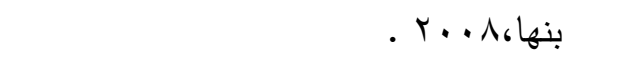 \\
\hline · جمال أمين محمود عبد العال ،" تطوير & أيسم سعد محمدي محمود ،"مشكلات \\
\hline برامج الدراسات العليا بكلية التربية & تطبيق نظام الساعات المعتدة في \\
\hline جامعة المنوفية في ضوء أهدافها" ، & الدراسات العليا التربوية "،مجلة العلوم \\
\hline رسالة دكتوراه غير منشورة ، كلية التربية & التربوية، معهدالدراساتوالبحوث \\
\hline 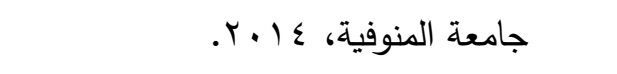 & التربوية، جامعة القاهرة ، مج (YM) ،ع \\
\hline r ا. حسن شحاته، زينب النجار، حامد عمار ، & (1)، ج (1)، يناير 10 • r. البحث كامل \\
\hline " معجم المصلحات التربوية والنفسية & متاح علي : \\
\hline "،الطبعة الأولي، القاهرة: الدار المصرية & - \\
\hline 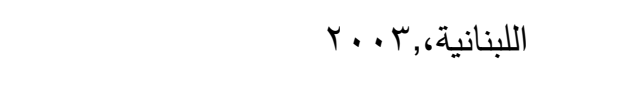 & $\begin{array}{l}\text { Jes/JesVol23No1P1Y2015/jes_2015-v23- } \\
\text { n1-p1 369-436.pdf. }\end{array}$ \\
\hline ع ا. جمال كامل الفليت، "دور البحوث التربوية & http://search.shamaa.org/AdvancedFullRec \\
\hline لبرامج الدراسات العليا في تطوير العملية & -.ord.aspx?ID=111330 \\
\hline التعليمية في محافظات غزة ومقترحات & 9. بديعة عز الدين محمد، "دراسة تقويمية \\
\hline تفعيله"، مجلة جامعة القدس المفتوحة & لبرنامج الماجستير لكلية التربية جامعة \\
\hline للأبحاث والدراسات التربوية والنفسية: & الفاشر"، رسالة ماجستير غير منشورة ، \\
\hline مج (r)، ع (•(1) ، نيسان 10 r & كلية التربية، جامعة الخرطوم السودان، \\
\hline جامعة الأزهر / غزة، فلسطين، 10 . . & 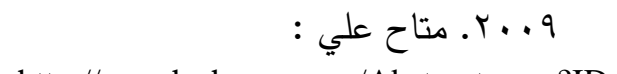 \\
\hline ه. حسن علي الدهمان ،"اتجاهات الأساتذة & $\begin{array}{l}\text { http://search.shamaa.org/Abstract.aspx?ID } \\
-.=53274 \& \text { Lang=Arabic }\end{array}$ \\
\hline في تقييم السياسات المنظمة للدراسات & • 1. تقربر زبارة المراجعة الداخلية ، دركز \\
\hline العليا في ليبيا" ،بحوث وأوراق عمل & ضمان الجودة وتتييم الأداء بجامعة \\
\hline المؤتمر العربي السنوي الثالث حول & المنصورة ، والتي وافق عليها مجلس \\
\hline ات الحديثة لتعزيز جودة أداء & \\
\hline
\end{tabular}




\begin{tabular}{|c|c|}
\hline 9 ا ـ دليـل كليـة التربيـة النوعيـة جامعـة أسـوان & الجامعات في الوطن العربي"، جامعة \\
\hline متاح الكترونيـا علي موقع كليـة التربيـة & الدول العربية المنظمة العربية للتتمية \\
\hline النوعية جامعة أسوان. & الإدارية، المنعقد في الشارقة دولة \\
\hline -http://spec.aswu.edu.eg & 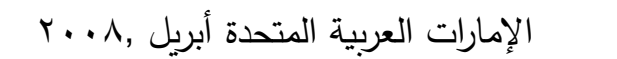 \\
\hline • r-ـ رافـدة عمـر الحريـري،" التتـوبح التربـوي & 7 ا. حسين جدوع مظلوم ، كريم بلاسم خلف، " \\
\hline الثـــامل للمؤسســة المدرسـية"، ط( ()، & تقويم برامج الدراسـات العليا في جامعـة \\
\hline المملكـة الأردنيـة الهاشـمية عمـان: دار & القادسية من وجهة نظر الطلبة"، مجلـة \\
\hline 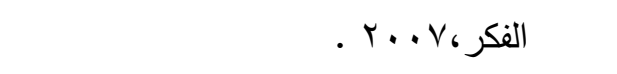 & القادسـية في الآداب والعلـوم التربوبــة، \\
\hline ا r - زينب محمد حسن خليفة،"فعاليـة برنـامج & 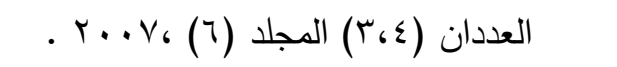 \\
\hline في التربيـة المكتبـــة لطـلاب الدراسـات & V ا ـ حمزة بن عبد الحكم، علي الصغير عبد \\
\hline العليـا باسـتخدام الموديـولات التعليميـة"، & العـال حسـن ، "برنـامج تـدريبي مقتـرح \\
\hline رسالة دكتوراه غير منشورة ، كلية التربية & لتتميــة مهــارات البحــث العلمـي لــدى \\
\hline جامعة عين شمس ، ( . . . . & طـلاب الدراسـات العليـا بجامعـة الملـك \\
\hline r r. سعاد محمد عيد محمد نصر ، " التخطيط & خالــــد"، المجلــــة التربوبـــــة الدوليـــــة \\
\hline لتطـوير بـرامج الدراسـات العليـا بكليـات & المتخصصة، جامعة الملك خالد المملكة \\
\hline التربية "، رسالة ماجستير غير منشورة ، & العربيــة الســعودية، مـــج (ب) ع ( ) (1) \\
\hline 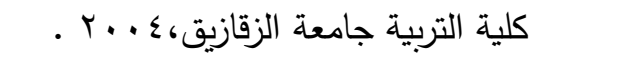 & 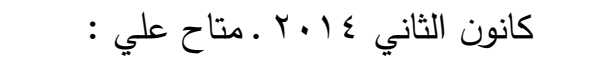 \\
\hline سז_ سـلوى فتحـي محمـود المصـري،"برنامج & http://www.iijoe.org/v3/IIJOE_06_01_03_ \\
\hline مقترح لتتمية مهارات استخدام المصـادر & $\begin{array}{r}-.2014 . p d f \\
\text { http://search.shamaa.org/Advanced }\end{array}$ \\
\hline الرقمية لطلاب الدراسـات العليا "، مجلة & -Record.aspx?ID=90913. \\
\hline العلوم التربوية، معهد الدراسات التربوية، & 1 ا. خالد سليمان عبد الحليم عبد النبي ،"تقويم \\
\hline جامعـة القـاهرة ، مـج (1 ())، ع خـاص، & بـرامج الدراسـات العليـا بكليـات السـياحة \\
\hline 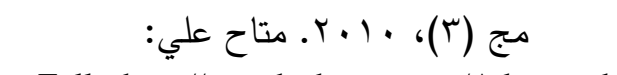 & والفنادق "، رسالة دكتوراه غير منشورة- \\
\hline 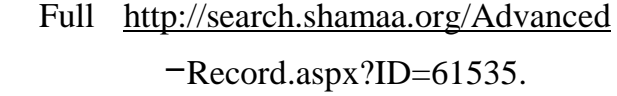 & كليــــة الســــاحة والفنــــادق جامعــــة \\
\hline http://search.shamaa.org/Abstract.aspx?ID & 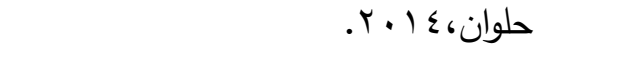 \\
\hline & \\
\hline
\end{tabular}




\begin{tabular}{|c|c|}
\hline التربـوي بكليـة العلـوم الاجتماعيـة مـن & ـ ז. شادية عبد الحليم تمام،" برامج الدراسات \\
\hline وجهــة نظـر طـلاب وطالبـات المــازي & العليا التربوية بجامعة القاهرة : دراسة \\
\hline الملتحقين بـه"، مجلــة اتحـاد الجامعـات & تقويمية في ضوء معايير الجودة "،مجلة \\
\hline العربيــة للبحــوث فـي التعلـيم العـالي، & العلوم التربوية معهدالدراسات \\
\hline المجلد(35) ، العـدد(1) كليـة العلـوم & والبحوث التربوية ، جامعة القاهرة، مج \\
\hline الاجتماعيـة، جامعــة الإمــام محمــــــن & (Y. \\
\hline ســـود الإســـلامية، المملكـــة العربيـــة & \\
\hline
\end{tabular}

السعودية، حزيـران 2015 ـ متاح علي:

- /eulc v5http://www.eulc.edu.eg

9. علي عبد ربـه حسين إسماعيل، " تطبيق

إسـتراتيجية سـتة سـيجما لتحقيـق الميـزة

التتافسية للدراسـات العليـا بكليـة التربيـة

جامعـة المنصسورة"، مجلـة كليـة التربيـة

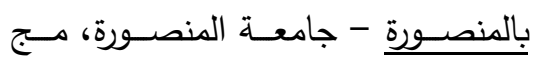

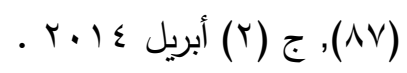

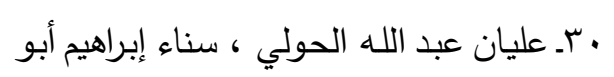

دقة ، "تقويم برامج الدراسات العليا في

الجامعة الإسلامية بغزة من وجهة نظر بلري

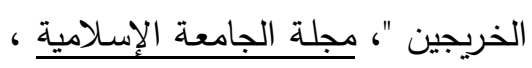

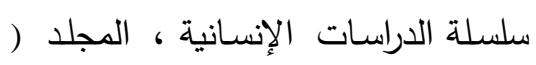

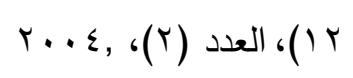

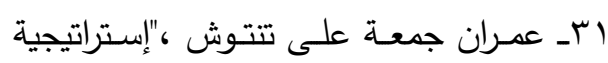

مقترحة لمواجهة الضغوط النفسية لطلبة

الدراسـات العليـا بكليـات وأقسـام التربيـة

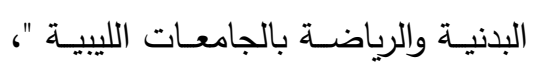

رسالة دكتوراه غير منشورة، كلية التربية

http://search.shamaa.org/AdvancedFullRec -ord.aspx?ID=73526

ه. صلاح الدين علام ،"التقوبع التربوي

المؤسسي أسسه ومنهجياته وتطبيقاته في

تقويم المدارس "، القاهرة مصر: دار

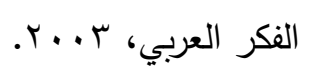

צr ـ عبد الرحمن محمد سعيد الثامي، "تقوبح

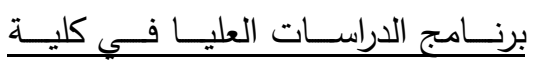

الإعلام"، دراسة حالة، نحو فضاء عربي

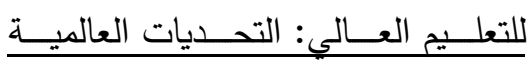

والمسؤوليات المجتمعية : أعمال المؤتمر

الإقليمسي العربـي حـول التعليم العـالي،

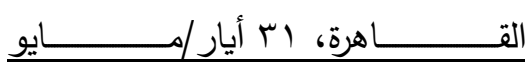

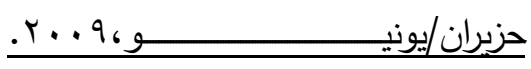

http://search.shamaa.org/FullRecord ?ID $=27902$

rV

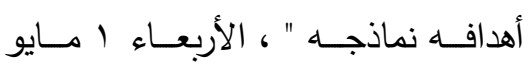

$$
-r \cdot T
$$

http://abdulkrem556.blogspot.com .eg/2013/05/blog-post.html.

^ץ ــ عبد الله بـن عبدالرحمن الفنتوخ،" تقويم

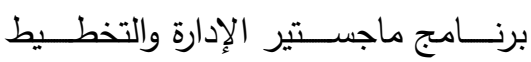




\begin{tabular}{|c|c|}
\hline أعضــاء هيئـة التـدريس وطلبــة الدراسـات & الرياضــــــــــة للبنــــــــات جامعـــــــــة \\
\hline العليـا"، مجلـــة دراســات العلــوم التربوبـــة & 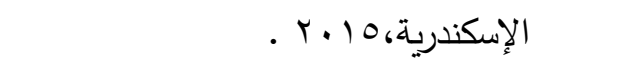 \\
\hline 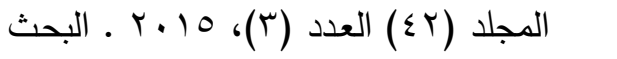 & r rــ فاتــة الشـريف، " آليـات مقترحـة لتقـويم \\
\hline كامل متاح علي: & بـرامج الدراســات العليـا" ، مجلــة عجـــان \\
\hline https://journals.ju.edu.jo/old/index.php/Dir & للدراســات والبحــوث: الإمـارات العربيــة \\
\hline asatEdu/article/viewFile/5581/4839.- & المتحـدة مـج (· (1) ، ع (1)، الإمـارات \\
\hline דr- محمـ سـعد إبراهيم، " إشـكاليات التأهيل & \\
\hline والتـدربب في أقســام الإعـلام بالجامعـات & http://www.rsh- \\
\hline الإقليمية "، مجلة الآداب والعلوم الإنسانية & award.org.ae/Majalat\%20Ajman/jorna \\
\hline بجامعة المنيا ، مج (1) ع (•.0) أكتوبر ، & http://search.shamaa.org/AdvancedSearch. \\
\hline.$r \ldots$ & - .aspx?lookfor \\
\hline 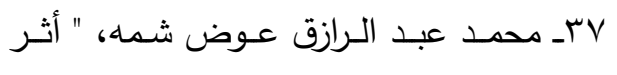 & سبـ لمياء شوقت على أحمد،" رؤيـة مستقبلية \\
\hline التفاعـل بـين مــخلين لتصــميم المقـررات & لتطـوير منظومــة الدراسـات العليـا بكليـة \\
\hline الإلكترونيــــة عبـــر الإنتـــرنت وبعـض & الاقتصـاد المنزلي لتحقيق الجودة الثـاملة \\
\hline الأسـاليب المعرفيـة على التحصيل وتتمية & في ضوء خبرات بعض الدول"، مجلة كلية \\
\hline مهارات التفكير العليا لدى طلاب الدبلوم & الاقتصـاد المنزلي ، جامعـة المنوفيـة، مـج \\
\hline الخاصـة في التربية"، رسـالة دكتوراه غير & 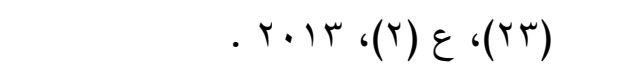 \\
\hline منشـورة، كليــة البنــات لــلآداب والعـــوم & 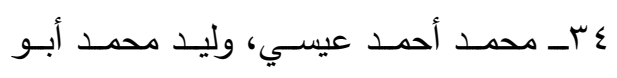 \\
\hline والتربية جامعة عين شمس،9 . F . . & المعاطي ، " تقويم برنامج الدراسات العليا \\
\hline مبــــليــة التربيــة النوعيـة أشــون، " التعلـيم & بكليـة التربيـة جامعـة الطـائف مـن وجهـة \\
\hline وريــادة الأعمــال التحــيات والتطـــوير" ، & نظـر أعضــاء هيئـة التـدريس والطـلاب، \\
\hline ملخـص أبحـاث المـؤتمر العلمي الـدولي & مجلة بحوث التربية النوعية ، كلية التربية \\
\hline الخــامس كليــة التربيــة النوعيـة جامعــة & النوعيـة جامعـة المنصـورة، العـدد (9 ( ) ، \\
\hline 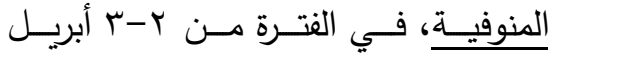 & 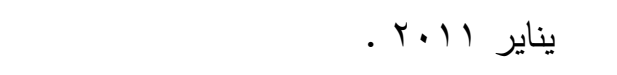 \\
\hline$r \cdot I V$ & هبـ محمــ حسـن سـعيد آل سـفران ، "تقـويم \\
\hline qr. لمى فاخر عبد الرازق، ثناء شاكر حمودي & برامج الدراسات العليا بكلية التربية جامعة \\
\hline ،"درجة الوعي المعلوماتي لدى طلبة & 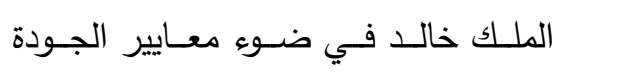 \\
\hline الماجستير في جامعة الزرقاء والجامعة & والاعتمــاد الأكــاديمي مـن وجهـة نظــر \\
\hline
\end{tabular}




$$
\begin{aligned}
& \text { 0ــــاجي عبد الوهـاب هـلال ، وعلـي بـن } \\
& \text { صـالح الثـايع ، "تطوير الدراسـات العليا }
\end{aligned}
$$

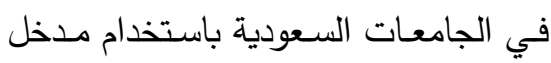

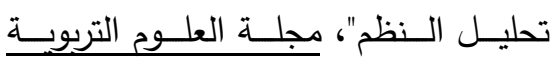

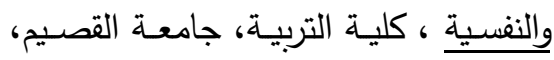

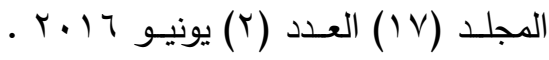

$$
\begin{aligned}
& \text { متاح علي: } \\
& \text { لوائح كليات التربية النوعية: } \\
& \text { بالعباسية جامعة عين شمس. }
\end{aligned}
$$

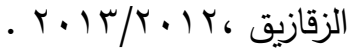

^ــ دليل الكلية لمرحلة الدراسات العليا بنظام

السـاعات المعتمـدة كليـة التربيـة النوعيـة

$$
\text { جامعة بنها. }
$$

9ـــــلائحسـة الداخليـة لكليـة التربيـة النوعيـة

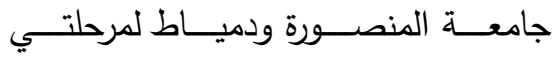

$$
\text { البكالوريوس والدراسات العليا. }
$$

•ـ دليل طلاب الدراسات العليا بكلية التربية

$$
\text { النوعية جامعة طنطا. }
$$

10ـ اللائحسة الداخليـة للدراسـات العليـا بكليـة

التربية النوعية بأشمون جامعة المنوفية.

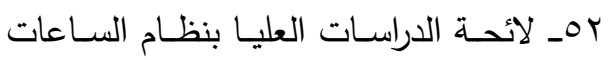

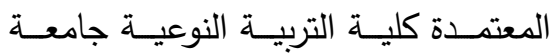

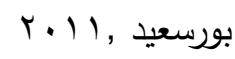

الهاشمية في مدى تحديد طبيعة ومحتوى

المعلومات المطلوبة لديهر من وجهة نظرهم

وفق المعيار الدولي ACRLS "، مجلة

اتحاد الجامعات العربية للبحوث في التعليم

العالي ، المجلد(35)، العدد((1) حزيران

.2015

• عـــعجم لســان العـرب، متـاح علـي :

- http://www.almaany.com/ar/dict/ar

ا اءــ معجم المعـاني الجـامع، متــاح علـي :

- http://www.almaany.com/ar/dict/ar-

r عـ مروة بكر مختار الدياسطى ، "متطلبات

الحد من الهدر التعليمي بالدراسات العليا

بجامعة المنصورة"، رسالة ماجستير غير

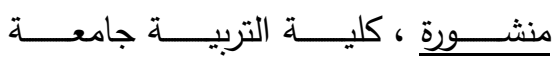

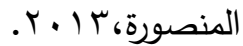

بـ منصور نـايف ماشـع العتيبي، علي أحمد

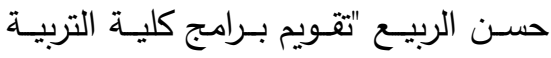

NCATE مجامعة نجران في ضوء معايير

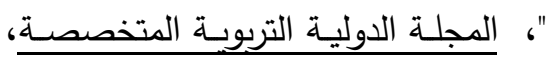

المجلـــد (1)، العــدد (9) تثـــرين أول

2012. متاح علي:

http://www.iijoe.org/volume1/IIJE_02_09

_2012.pdf

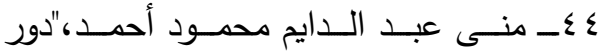

المنظمات الأكاديميـة في تتميـة المهارات

البحثيـة لـدى طـلاب الخدمـة الاجتماعيـة"

رسالة ماجستير غير منشورة، كلية الخدمة

الاجتماعية جامعة حلوان، 9 . . ب. 


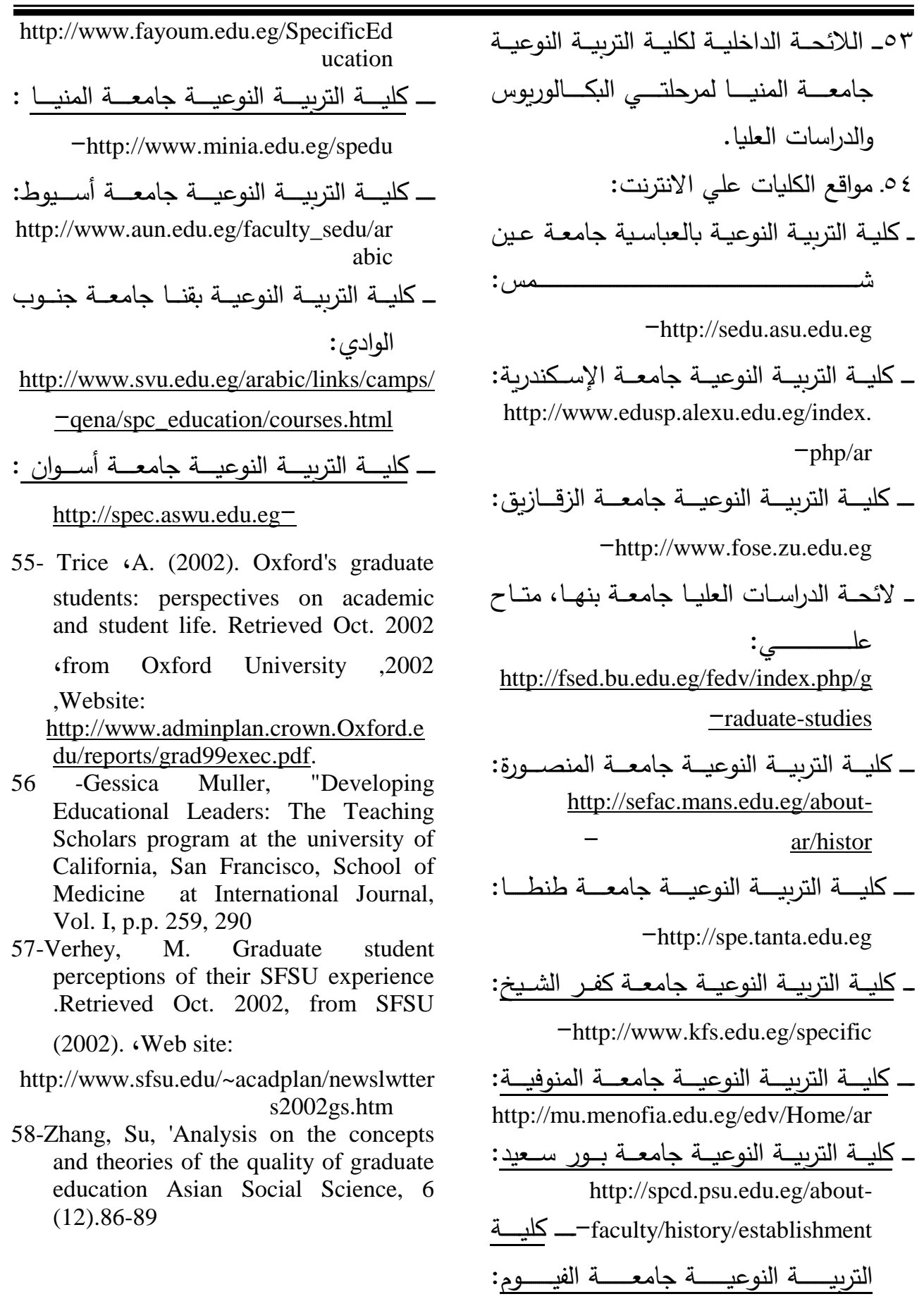

